\title{
INVESTIGATION OF THE LIFE CYCLE CARBON IMPACT OF PASSIVE HOUSE BUILDING ENVELOPES IN CANADA
}

By

\author{
Patrick Werner Andres
}

B.Eng. Environmental Engineering, University of Guelph, 2008

\author{
A thesis presented to \\ Ryerson University \\ in partial fulfillment of the \\ requirements for the degree of \\ Master of Applied Science \\ in the Program of \\ Building Science
}

Toronto, Ontario, Canada 2015

(C) Patrick Werner Andres 2015 


\section{Author's Declaration For Electronic Submission of A Thesis}

I hereby declare that I am the sole author of this thesis. This is a true copy of the thesis, including any required final revisions, as accepted by my examiners.

I authorize Ryerson University to lend this thesis to other institutions or individuals for the purpose of scholarly research.

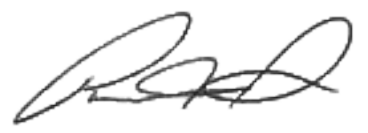

I further authorize Ryerson University to reproduce this thesis by photocopying or by other means, in total or in part, at the request of other institutions or individuals for the purpose of scholarly research.

I understand that my thesis may be made electronically available to the public.

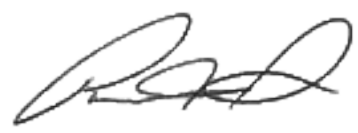




\title{
INVESTIGATION OF THE LIFE CYCLE CARBON IMPACT OF PASSIVE HOUSE BUILDING ENVELOPES IN CANADA
}

Master of Applied Science 2015 - Patrick Werner Andres - Building Science Program Ryerson University

\begin{abstract}
Whole building energy and life cycle impact modeling was conducted for a singlefamily detached reference building designed to meet the Passive House Standard. Life cycle operating global warming potential (GWP) and building envelope embodied GWP were assessed for two mechanical system configurations and three Canadian cities. Variations in regional electricity carbon intensity were found to significantly impact both operating and embodied GWP. Embodied GWP was found to be significant relative to operating GWP in locations with access to low carbon electricity. Additionally, use of natural gas mechanical systems in Edmonton resulted in 360\% greater operating emissions than in Montreal, while electric heat pump mechanicals yielded 6,600\% higher emissions. Finally, the Passive House Standard method for quantifying operating GWP was found to overestimate emissions by up to $3700 \%$ in Montreal and underestimate emissions by $34 \%$ in Edmonton, when compared to a method accounting for variations in regional electricity carbon intensity.
\end{abstract}




\section{Acknowledgements}

First of all, I would like to thank my thesis advisor, Dr. Russell Richman, for guiding me through the process of developing this thesis. You always kept me grounded in reality and helped me to communicate my ideas on this complex topic. Thank you for your encouragement and friendship over the past two years. I must also thank Dr. Miljana Horvat, Dr. Mark Gorgolewski and the entire Ryerson Building Science faculty and staff for making the program such an enjoyable experience. It is rare to meet a group of people who so thoroughly enjoy their work. Their level of enthusiasm and hope for change in the building industry has instilled in me a great sense of optimism for the future. To my parents, Anne and Philipp, thank you for providing me with such an amazing opportunity to pursue my dreams. Your unwavering support through the years has allowed me to find my passion in life. To my brother Daniel, your advice and help will not soon be forgotten. Although you are my little brother, I will always look up to you for your intense desire to learn more about our world. Finally, to my wife Karen Finney, you have given me such immense encouragement and support. Your love and patience kept me motivated and for this I will remain forever grateful. 


\section{Table of Contents}

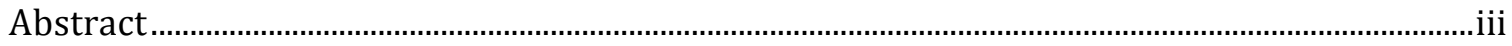

Acknowledgements..............................................................................................................................

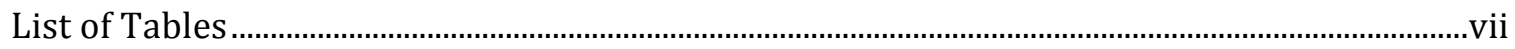

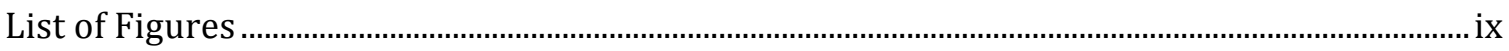

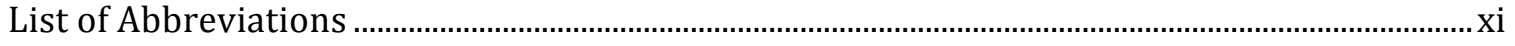

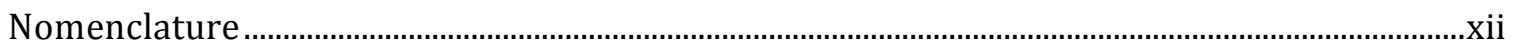

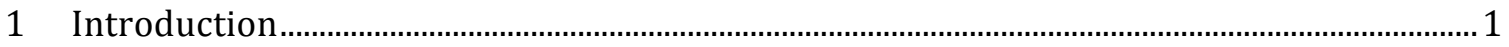

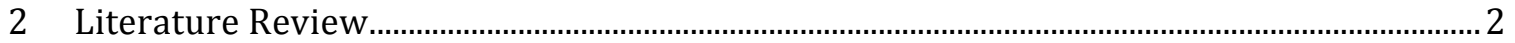

2.1 Background on the Passive House Standard......................................................................... 2

2.2 Recent Literature on Passive House Life Cycle Greenhouse Gas Emissions................... 4

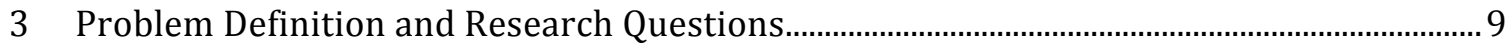

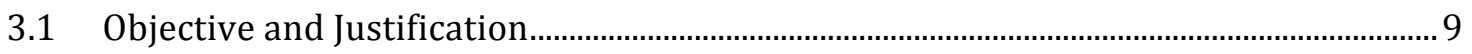

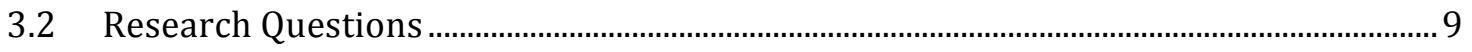

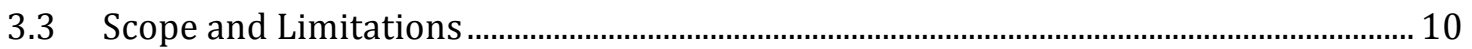

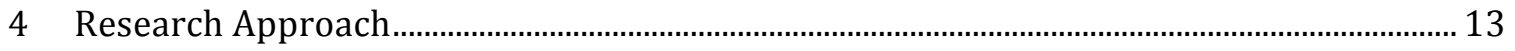

4.1 Research Method Overview ………………....................................................................... 13

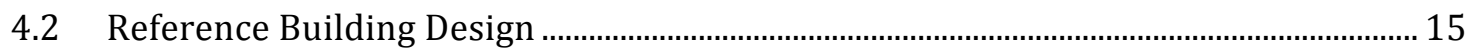

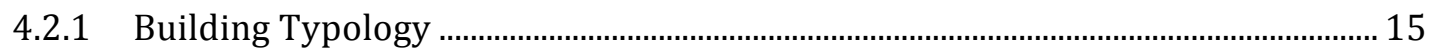

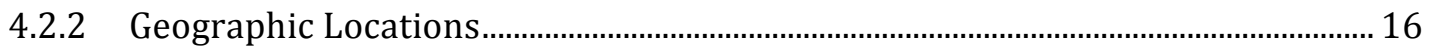

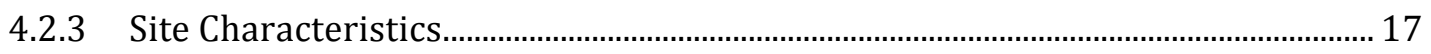

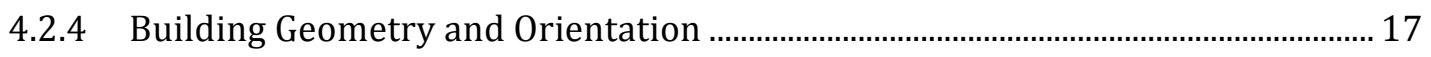

4.2.5 Building Envelope.......................................................................................... 18

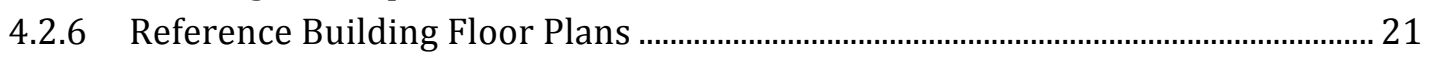

4.2.7 Thermal Bridging......................................................................................... 24

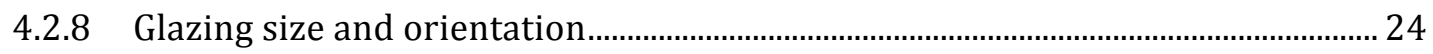

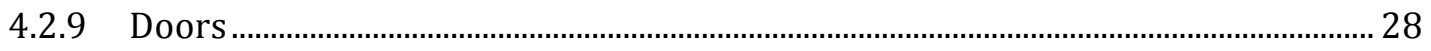

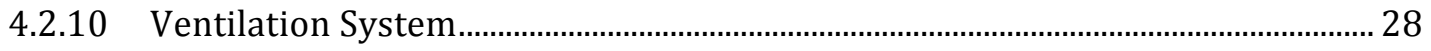

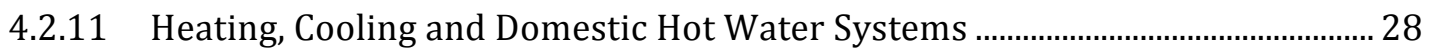

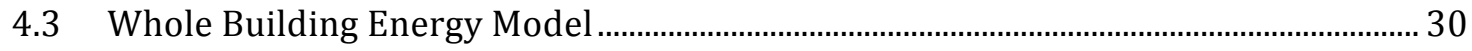

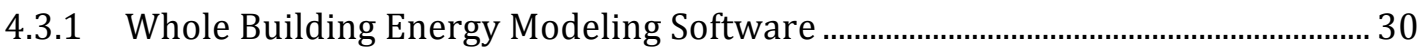

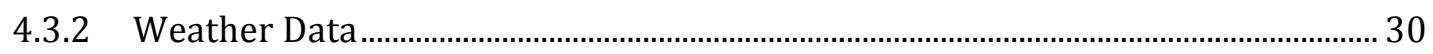

4.3.3 Metrics for Assessment ...................................................................................... 31

4.3.4 WUFI Passive Modeling Procedure \& Assumptions ................................................... 31

4.3.5 Verification of WUFI Passive Model Parameters ……….............................................. 31

4.4 Building Envelope Greenhouse Gas Model …….................................................................. 32

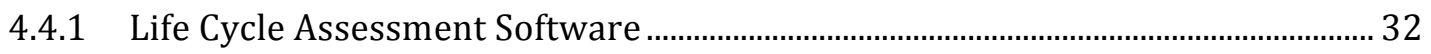

4.4.2 Software Version and Data Sources.............................................................................. 32 


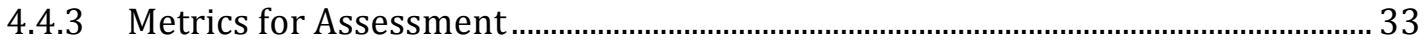

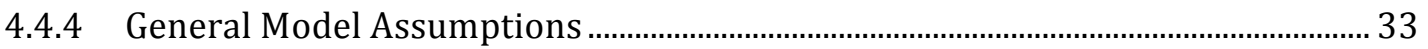

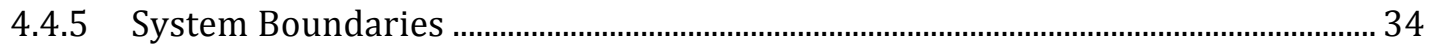

$4.5 \quad$ Reference Building Model ……........................................................................................... 34

4.5.1 Impact of Assembly Material Choice on Embodied GWP ....................................... 34

4.5.2 Analysis of Reference Building Operating Energy Consumption and Operating GWP 37

4.5.3 Comparison of Envelope Embodied GWP and Operating GWP .............................. 38

4.5.4 Comparison of Passive House Standard and Regional Based Methods for

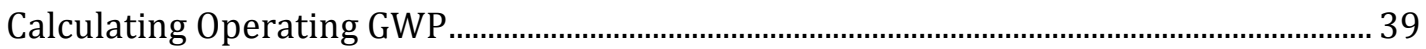

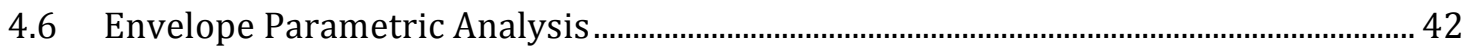

4.6.1 Impact of Insulation Thickness on Envelope Embodied GWP .................................. 42

4.6.2 Relative Impact of Insulation Thickness on Building Life Cycle GWP ................... 46

$4.7 \quad$ Envelope Life Cycle Optimization Model ............................................................................. 48

4.7.1 Selection of Envelope Scenarios Based on Life Cycle GWP ………............................ 48

4.7.2 Selection of Passive House Envelope Scenarios Optimized for Life Cycle GWP 49

4.7.3 Comparison of Envelope Scenario Annual Heat Demand and Life Cycle GWP .. 52

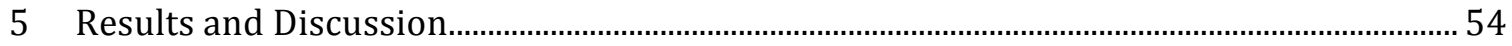

5.1 Results of Reference Building Models ........................................................................... 54

5.1.1 Impact of Envelope Material Choice on Embodied GWP .......................................... 54

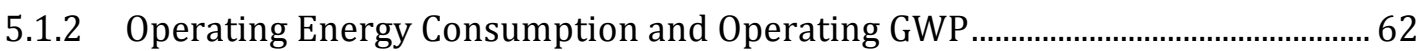

5.1.3 Comparison of Passive House Standard and Regional Based Method Operating

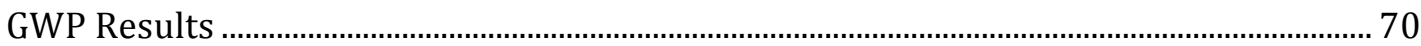

5.2 Envelope Parametric Analysis Results......................................................................... 72

5.2.1 Impact of Insulation Thickness on Envelope Embodied GWP ................................ 72

5.2.2 Impact of Insulation Thickness on Building Life Cycle Global Warming Potential 81

$5.3 \quad$ Envelope Life Cycle Optimization Results …….............................................................. 92

5.3.1 Selection of Envelope Scenarios Based on Life Cycle GWP ..................................... 92

5.3.2 Comparison of Envelope Scenario Annual Heat Demand and Life Cycle GWP .. 99

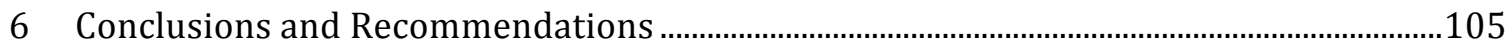

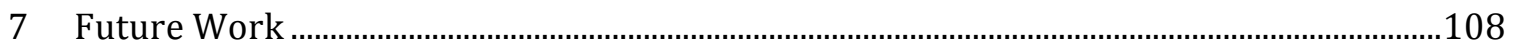

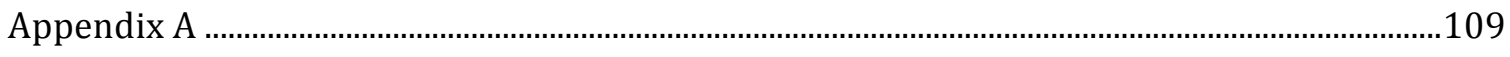

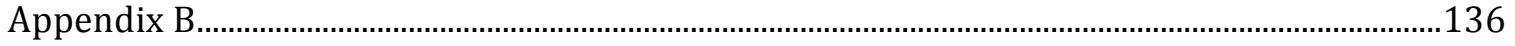

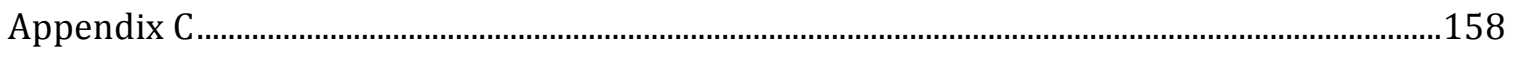

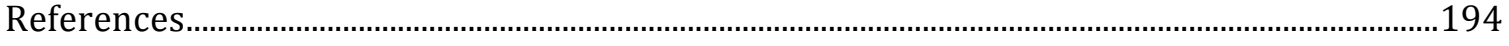




\section{List of Tables}

Table 2-1 Passive House Certification Requirements, adapted from BRE (2011) ...................... 3

Table 4-1 National and Provincial Average Detached Dwelling Household Size and Area.... 16

Table 4-2 - Subject Location Climate Factors …………........................................................................ 16

Table 4-3 Electricity Generation Carbon Intensity by Province........................................................ 17

Table 4-4 Reference Building Envelope Properties............................................................................... 19

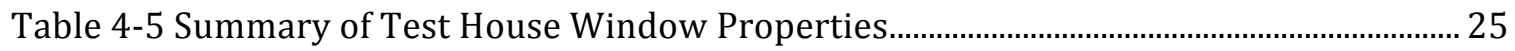

Table 4-6 Summary of Test House Door Properties........................................................................... 28

Table 4-7 Summary of Mechanical System Equipment..................................................................... 29

Table 4-8 Summary of Assembly Insulation Materials Selected for Analysis of Embodied

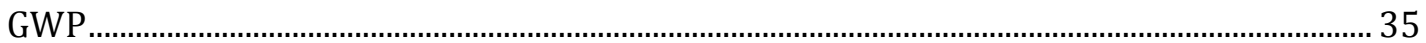

Table 4-9 Provincial Electricity Production, Export and Import Data.......................................... 41

Table 4-10 Wall Assembly Iteration Insulation Levels ..................................................................... 43

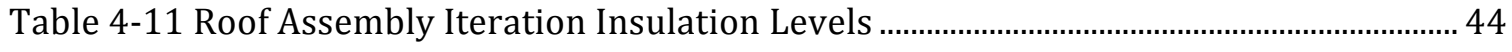

Table 4-12 Slab Assembly Iteration Insulation Levels ...................................................................... 45

Table 4-13 Summary of Iteration Assembly Insulation Levels........................................................ 46

Table 4-14 Summary of Selected Assemblies for Case A (NG) and Case B (Electric) Passive

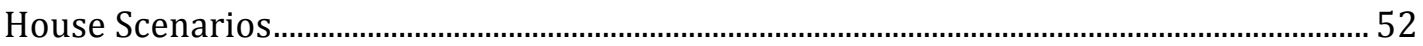

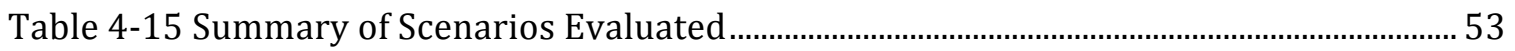

Table 5-1 Summary of Reference Building Wall Assembly Embodied GWP............................... 55

Table 5-2 Summary of Reference Building Roof Assembly Embodied GWP .............................. 56

Table 5-3 Summary of Reference Building Slab Assembly Embodied GWP ............................... 57

Table 5-4 Impact of Envelope Insulation Material Type on Embodied GWP .............................. 58

Table 5-5 Impact of Wall Cladding Material on Total Envelope Embodied GWP ...................... 61

Table 5-6 Results of Reference Building Assembly Material Substitution Analysis................. 62

Table 5-7 Annual Heat Demand and Heating Degree Days for Assessed Locations.................. 64

Table 5-8 Historic and Life Cycle Carbon Intensities of Electricity ………....................................... 66

Table 5-9 Summary of Envelope Embodied Impacts Compared to Operating GWP ................. 68

Table 5-10 Case A (NG): Comparison of Athena IE and WUFI Passive Results for Operating Greenhouse Gas Emissions

Table 5-11 Case B (Electric): Comparison of Athena IE and WUFI Passive Results for Operating GWP 
Table 5-12 Case A (NG): Calculated Change in Envelope Life Cycle Global Warming Potential with Increasing Wall Insulation Thickness .............................................................................. 93

Table 5-13 Case A (NG): Calculated Reduction in Global Warming Potential with Increasing

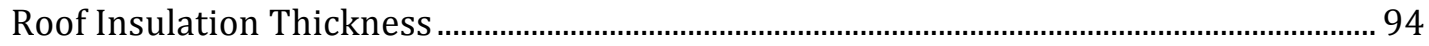

Table 5-14 Case A (NG): Calculated Reduction in Global Warming Potential with Increasing Slab Insulation Thickness.

Table 5-15 Case B (Electric): Calculated Reduction in Global Warming Potential with Increasing Wall Insulation Thickness .......................................................................................... 96

Table 5-16 Case B (Electric): Calculated Reduction in Global Warming Potential with Increasing Roof Insulation Thickness ………............................................................................ 97

Table 5-17 Case B (Electric): Calculated Reduction in Global Warming Potential with

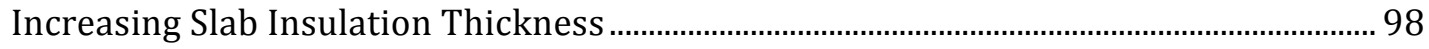

Table 5-18 Summary of Assemblies Selected for Case A (NG) and Case B (Electric) Scenarios 99

Table 5-19 Summary of Trendline Slope Analysis . .104 


\section{List of Figures}

Figure 3-1 Elements of Building Life Cycle GWP Included in Assessment.......................... 11

Figure 4-1 Overview of Research Methods ...................................................................................... 13

Figure 4-2 Test House Reference Building Wall Section (adapted from PHIUS, 2013a)......... 20

Figure 4-3 Test House First Storey Floor Plan and Mechanical System Layout.......................... 22

Figure 4-4 Test House Second Storey Floor Plan and Mechanical System Layout..................... 23

Figure 4-5 Reference Building North Elevation …….................................................................... 26

Figure 4-6 Reference Building West Elevation .................................................................................... 26

Figure 4-7 Reference Building South Elevation............................................................................... 27

Figure 4-8 Reference Building East Elevation................................................................................. 27

Figure 4-9 North American Grid Interconnections, adapted from NERC (2013) ...................... 41

Figure 4-10 Brute-force method for selecting Passive House assemblies with lowest life

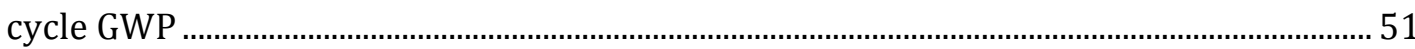

Figure 5-1 Impact of Location and Mechanical System Choice on Life Cycle Operating Energy Consumption.

Figure 5-2 Impact of Location and Mechanical System Choice on Life Cycle Operating GWP

Figure 5-3 Impact of Location and Mechanical System Type on Embodied and Operating GWP

Figure 5-4 Comparison of Toronto Wall Assembly Material Type Embodied GWP ................. 74

Figure 5-5 Comparison of Montreal Wall Assembly Material Type Embodied GWP ................ 74

Figure 5-6 Comparison of Edmonton Wall Assembly Material Type Embodied GWP ............ 75

Figure 5-7 Comparison of Toronto Roof Assembly Insulation Type Embodied GWP ............. 77

Figure 5-8 Comparison of Montreal Roof Assembly Insulation Type Embodied GWP ............ 77

Figure 5-9 Comparison of Edmonton Roof Assembly Insulation Type Embodied GWP ......... 78

Figure 5-10 Comparison of Toronto Slab Assembly Insulation Type Embodied GWP ............ 79

Figure 5-11 Comparison of Montreal Slab Assembly Insulation Type Embodied GWP .......... 80

Figure 5-12 Comparison of Edmonton Slab Assembly Type Embodied GWP............................... 80

Figure 5-13 Case A (NG): Impact of Wall Insulation Thickness on Life Cycle GWP ................... 82

Figure 5-14 Case A (NG): Impact of Roof Insulation Thickness on Life Cycle GWP................... 83

Figure 5-15 Case A (NG): Impact of Slab Insulation Thickness on Life Cycle GWP.................... 84 
Figure 5-16 Case B (Electric): Impact of Wall Insulation Thickness on Life Cycle GWP ......... 86 Figure 5-17 Case B (Electric): Impact of Wall Insulation on Life Cycle GWP (TO and MTL

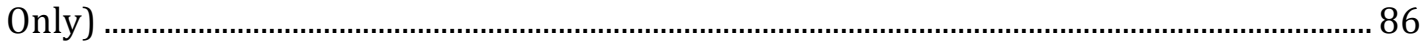

Figure 5-18 Case B (Electric): Impact of Roof Insulation Thickness on Life Cycle GWP ......... 88 Figure 5-19 Case B (Electric) Impact of Roof Insulation on Life Cycle GWP (TO and MTL

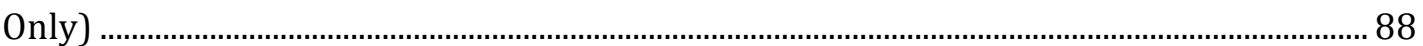

Figure 5-20 Case B (Electric): Impact of Slab Insulation Thickness on Life Cycle GWP .......... 90 Figure 5-21 Case B (Electric): Impact of Slab Insulation on Life Cycle GWP (TO and MTL

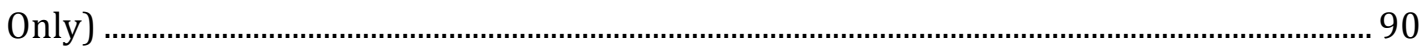

Figure 5-22 Case A (NG): Life Cycle GWP and AHD Intensity of Building Envelope Scenarios 100

Figure 5-23 Case B (Electric): Life Cycle GWP and AHD Intensity of Building Envelope Scenarios.

Figure 5-24 Case A: Relationship Between Life Cycle GWP and Annual Heat Demand .........102

Figure 5-25 Case B: Relationship Between Life Cycle GWP and Annual Heat Demand .........103 


\title{
List of Abbreviations
}

\author{
AHD - annual heat demand \\ $\mathrm{CO}_{2}$ - carbon dioxide \\ $\mathrm{CO}_{2}$ eq - carbon dioxide equivalent \\ COP - coefficient of performance \\ DHW - domestic hot water \\ EDM - Edmonton \\ EPS - expanded polystyrene \\ GWP - global warming potential \\ HDD - heating degree days \\ HPWH - heat pump water heater \\ HRV - heat recovery ventilator \\ HSPF - heating season performance factor \\ IGU - insulated glazing unit \\ LC - life cycle \\ MTL - Montreal \\ PHIUS - Passive House Institute U.S. \\ SHGC - solar heat gain coefficient \\ TO - Toronto \\ TFA - treated floor area \\ XPS - extruded polystyrene
}




\section{Nomenclature}

\begin{tabular}{|c|c|}
\hline Annual COP & annual coefficient of performance \\
\hline$\delta_{b u}$ & Fraction of backup heating required \\
\hline$\delta_{h p}$ & Fraction of heating supplied by heat pump \\
\hline $\operatorname{COP}_{(\operatorname{Adj})}$ & climate adjusted annual COP of heat pump \\
\hline COP cooling & heat pump cooling season coefficient of performance \\
\hline$C O P_{T, n}$ & heat pump coefficient of performance at temperature $n$ \\
\hline$d_{\text {wall }}$ & thickness of exterior wall, $\mathrm{m}$ \\
\hline$E F$ & heat pump manufacturer's stated efficiency factor \\
\hline EER & heat pump energy efficiency ratio, BTU/Wh \\
\hline$H D H_{L T C}$ & $\begin{array}{l}\text { number of heating degree hours up to the low temperature } \\
\text { cutout point of the heat pump (from } \mathrm{T}_{\min } \text { to } \mathrm{T}_{\mathrm{LTC}} \text { ), } \mathrm{Kh} / \mathrm{yr}\end{array}$ \\
\hline$H D H_{\text {total }}$ & total number of heating degree hours, $\mathrm{Kh} / \mathrm{yr}$ \\
\hline$H D H\left(T_{i}\right)$ & number of heating degree hours for temperature bin $i, \mathrm{Kh} / \mathrm{yr}$ \\
\hline$H S P F_{(A d j)}$ & Climate adjusted heat pump HSPF, BTU/Wh \\
\hline$H S P F_{(I V)}$ & $\begin{array}{l}\text { heating season performance factor of heat pump for climate } \\
\text { zone IV, BTU/Wh }\end{array}$ \\
\hline HPWH COP Winter & heat pump water heater system COP during the heating season \\
\hline$h_{i}$ & internal floor to ceiling height, $\mathrm{m}$ \\
\hline$l_{\text {ext }}$ & exterior length of building, $\mathrm{m}$ \\
\hline$n$ & number of occupants, persons \\
\hline$n_{\text {hours }, i}$ & $\begin{array}{l}\text { number of hours in 1-year TMY file for temperature }=T_{a m b, i} \\
\text { hours }\end{array}$ \\
\hline Op GWP aux & $\begin{array}{l}\text { operating global warming potential of auxiliary equipment, } \mathrm{Mg} \\
\mathrm{CO}_{2} \mathrm{eq}\end{array}$ \\
\hline Op GWP final & final operating global warming potential, $\mathrm{Mg} \mathrm{CO}_{2} \mathrm{eq}$ \\
\hline Op GWP mech & $\begin{array}{l}\text { operating global warming potential of mechanical systems, } \\
\mathrm{MgCO}_{2} \mathrm{eq}\end{array}$ \\
\hline$\phi_{h p}$ & heat pump heating capacity, $\mathrm{W}$ \\
\hline
\end{tabular}




\begin{tabular}{|c|c|}
\hline$P E F_{E L E C}$ & primary energy factor of electricity \\
\hline$P E F_{N G}$ & primary energy factor of natural gas \\
\hline$Q_{a p p}$ & appliance electricity demand, kWh/yr \\
\hline$Q_{a u x}$ & auxiliary equipment electricity demand, $\mathrm{kWh} / \mathrm{yr}$ \\
\hline$Q_{\text {vent }}$ & ventilation system electricity demand, kWh/yr \\
\hline$t_{\text {Cooling Season }}$ & length of cooling season, months \\
\hline$t_{\text {Heating Season }}$ & length of heating season, months \\
\hline$t_{\text {Total }}$ & length of year, 12 months \\
\hline Total Emb GWP & total embodied global warming potential, $\mathrm{Mg} \mathrm{CO}{ }_{2} \mathrm{eq}$ \\
\hline$T_{a m b, I}$ & ambient air temperature of bin $i,{ }^{\circ} \mathrm{C}$ \\
\hline$T_{\text {base }}$ & base temperature below which heating is required, $18^{\circ} \mathrm{C}$ \\
\hline$T_{d}$ & Manual J winter design temperature (heating $99 \%$ dry bulb), ${ }^{\circ} \mathrm{F}$ \\
\hline$T_{L T C}$ & low temperature cutout point of heat pump, ${ }^{\circ} \mathrm{C}$ \\
\hline$T_{n}$ & temperature of operating point to be extrapolated, ${ }^{\circ} \mathrm{C}$ \\
\hline$T F A$ & treated floor area, $\mathrm{m}^{2}$ \\
\hline$T S P R$ & total system performance ratio \\
\hline$V_{1 / 2 b a t h}$ & half-bath ventilation requirement, $\mathrm{m}^{3} / \mathrm{h}$ \\
\hline$V_{b a t h}$ & full-bath ventilation requirement, $\mathrm{m}^{3} / \mathrm{h}$ \\
\hline$V_{\text {Exhaust }}$ & ventilation exhaust air requirement, $\mathrm{m}^{3} / \mathrm{h}$ \\
\hline$V_{F A}$ & ventilation fresh air requirement, $\mathrm{m}^{3} /$ person-h \\
\hline$V_{\text {kitchen }}$ & kitchen ventilation requirement, $\mathrm{m}^{3} / \mathrm{h}$ \\
\hline$V_{\max }$ & maximum ventilation rate, $\mathrm{m}^{3} / \mathrm{h}$ \\
\hline$V n_{50}$ & net air volume for pressure test, $\mathrm{m}^{3}$ \\
\hline$V_{R}$ & volumetric ventilation requirement, $\mathrm{m}^{3} / \mathrm{h}$ \\
\hline$V_{\text {Supply }}$ & ventilation supply air requirement, $\mathrm{m}^{3} / \mathrm{h}$ \\
\hline$V_{V}$ & ventilation volume, $\mathrm{m}^{3} / \mathrm{h}$ \\
\hline$W_{i n}$ & heat pump electricity consumption, $\mathrm{W}$ \\
\hline$w_{\text {ext }}$ & exterior width of building, $\mathrm{m}$ \\
\hline $\mathrm{x} \mathrm{CO} 2$ & greenhouse gas emission factor, $\mathrm{g} \mathrm{CO}_{2} \mathrm{eq} / \mathrm{kWh}$ \\
\hline
\end{tabular}




\section{Introduction}

The Passive House Standard for building energy efficiency has been widely adopted across Europe, with over 25,000 projects completed as of 2010 (Zeller, 2010). The Passive House Standard was developed with the intention of reducing building energy consumption and associated greenhouse gas emissions to a rate that allows for mitigation of climate change related to the building sector (PHIUS, 2013a). Despite these stated goals, the standard does not currently account for the embodied global warming potential (GWP) associated with building materials nor does it recognize the varying carbon intensities of regional energy supply mixes, thereby failing to fully quantify all GWP over a building's entire life cycle.

The research presented aims to determine the impact of using the Passive House Standard method for calculating greenhouse gas emissions in place of a method that accounts for regional variations in electricity emission intensity. It is also an investigation of the impact that Passive House building envelope parameters and mechanical system fuel selection have on life cycle GWP for various locations across Canada. This will assist Passive House designers in selecting mechanical system equipment and envelope materials that result in lower life cycle GWP and lay the groundwork for future research assessing region-specific trade-offs of envelope and mechanical system parameters. 


\section{Literature Review}

\subsection{Background on the Passive House Standard}

The Passive House Institute U.S. (2013a), describes the Passive House Standard as "a performance-based and verifiable building energy metric that has been established based on global carbon reduction needed to avert the climate crisis as well as future costs of fossil fuels (peak oil) and therefore the economic feasibility to society" (p. 18). In addition to energy reductions, the Standard includes a set of comfort and indoor air quality criteria. To achieve these objectives, five main design principles are followed: (i) provide a continuous thermal envelope that avoids thermal bridging; (ii) ensure envelope air tightness to significantly reduce ventilation energy requirements; (iii) use climate appropriate vapour control layers in addition to a continuous air barrier to avoid the potential for interstitial moisture accumulation and related durability issues; (iv) select high-performance insulated glazing units (IGUs) that are appropriate to the climate; and (v) use climate specific continuous mechanical ventilation with energy recovery to deliver a continuous supply of fresh air to building occupants (PHIUS, 2013a).

One of the underlying assumptions behind the Passive House Standard is that by reducing the space-conditioning load to a level that can be delivered through the fresh air ventilation system, the need for a separate expensive central heating system is eliminated. Ideally, savings from excluding a central heating system offset the cost of upgrading insulation to sufficiently reduce the heating demand (Passive House Institute, 2012). However, according to Wright, Klingenberg, and Pettit (2014) and Abendroth (2014), this does not hold true for the cold continental climates of North America due to the presence of significantly higher peak heating loads compared to Central Europe. Although the intent of the Passive House Standard is to have heat supplied via the ventilation system, it does not preclude other methods of heat delivery nor does it specify a heating system type (PHIUS, 2013a; Cotterell \& Dadeby, 2012). 
The Standard is comprised of multiple criteria, including envelope air tightness, primary energy demand (PED), thermal and acoustic performance, and space conditioning energy consumption, which are summarized in Table 2-1. Energy performance criteria of the Passive House Standard are evaluated in relation to the building treated floor area (TFA), which is calculated using a formula based on the German Floor Area Ordinance (Feist, 2007).

Table 2-1 Passive House Certification Requirements, adapted from BRE (2011)

\begin{tabular}{|c|c|}
\hline \multicolumn{2}{|l|}{ Building Energy Performance } \\
\hline Specific Annual Heating Demand & $\leq 15 \mathrm{kWh} / \mathrm{m}^{2}-\mathrm{yr}$ \\
\hline (or Specific Peak Heat Load) & $\leq 10 \mathrm{~W} / \mathrm{m}^{2}$ \\
\hline Specific Annual Cooling Demand & $\leq 15 \mathrm{kWh} / \mathrm{m}^{2}-\mathrm{yr}$ \\
\hline Primary Energy Demand & $\leq 120 \mathrm{kWh} / \mathrm{m}^{2}-\mathrm{yr}$ \\
\hline \multicolumn{2}{|c|}{ Elemental Performance Requirements } \\
\hline Air Tightness & $\leq 0.6 \mathrm{ACH}(\mathrm{n} 50)$ \\
\hline Window U-value ${ }^{a}$ & $\leq 0.8 \mathrm{~W} / \mathrm{m}^{2}-\mathrm{K}$ \\
\hline Window Installed U-value ${ }^{a}$ & $\leq 0.85 \mathrm{~W} / \mathrm{m}^{2}-\mathrm{K}$ \\
\hline Linear Thermal Bridge Coefficient & $\leq 0.01 \mathrm{~W} / \mathrm{m}-\mathrm{K}$ \\
\hline \multicolumn{2}{|l|}{ Services Performance } \\
\hline $\begin{array}{l}\text { Heat Recovery Ventilator (HRV) } \\
\text { Efficiency }^{\mathrm{b}}\end{array}$ & $\geq 75 \%$ \\
\hline $\begin{array}{l}\text { Heat Recovery Ventilator (HRV) } \\
\text { Electrical Efficiency }\end{array}$ & $\leq 0.45 \mathrm{Wh} / \mathrm{m}^{3}$ \\
\hline \multicolumn{2}{|c|}{ Thermal and Acoustic Comfort Criteria } \\
\hline Overheating Frequency & $\geq 25^{\circ} \mathrm{C} \leq 10 \%$ of year \\
\hline Maximum Sound from HRV Unit & $35 \mathrm{~dB}(\mathrm{~A})$ \\
\hline $\begin{array}{l}\text { Maximum Transfer Sound in } \\
\text { Occupied Rooms }\end{array}$ & $25 \mathrm{~dB}(\mathrm{~A})$ \\
\hline \multicolumn{2}{|l|}{ Notes: } \\
\hline $\begin{array}{l}\text { Climate dependent recommended } \\
\text { whole window U-values }\end{array}$ & $\begin{array}{l}{ }^{b} \text { HRV efficiency must be calculated according to Passive } \\
\text { House Standard and not manufacturer's rating }\end{array}$ \\
\hline
\end{tabular}


Indoor air quality and thermal requirements of the Passive House Standard are defined by ISO 7730 (2005) and state that the wintertime indoor air temperature must remain at or above $20^{\circ} \mathrm{C}$ and the surface temperature of external walls and glazing must not be lower than $17^{\circ} \mathrm{C}$ when outdoor temperature is $-10{ }^{\circ} \mathrm{C}$ to maintain occupant comfort by preventing convection induced drafts at these locations (Cotterell \& Dadeby, 2012). Fresh air ventilation rates supplied to the building are defined by the German DIN 1946 health standard, which requires a minimum of $1 \mathrm{~m}^{3} /\left(\mathrm{m}^{2}-\mathrm{hr}\right.$ ) or $30 \mathrm{~m}^{3} / \mathrm{hr}$ per person (BRE, 2009). The Passive House Standard peak-heating load (PHL) of $10 \mathrm{~W} / \mathrm{m}^{2}$ is derived from the aforementioned health and comfort standards (Ibid.)

As an alternative compliance criterion to meeting $10 \mathrm{~W} / \mathrm{m}^{2} \mathrm{PHL}$, the standard is considered to be met if the annual heating demand (AHD) is less than or equal to $15 \mathrm{kWh} / \mathrm{m}^{2} \cdot \mathrm{yr}$. Additionally, the annual cooling demand (ACD) limit of $\leq$ $15 \mathrm{kWh} / \mathrm{m}^{2} \cdot \mathrm{yr}$ results from the ability of the required cooling to be supplied through the ventilation system, with the cooling coil maintaining an average temperature above $0{ }^{\circ} \mathrm{C}$. No specific requirement was developed for latent cooling, since it is not easily controllable through envelope design decisions (Schnieders et al., 2011). An additional requirement of the Passive House Standard is to minimize thermal bridging at all junctions of the building envelope. All material junctions and envelope transitions above the linear thermal bridge criteria of $\psi \leq 0.01 \mathrm{~W} / \mathrm{m} \cdot \mathrm{K}$ must be accounted for (Cotterell \& Dadeby, 2012).

\subsection{Recent Literature on Passive House Life Cycle Greenhouse Gas Emissions}

Research assessing the life cycle impacts of buildings constructed to the Passive House Standard has primarily been conducted for buildings located in Northern and Central European countries. Most literature reviewed used case study comparisons of life cycle primary energy or carbon impacts for various building types and different climates, leading researchers to often arrive at contradicting 
conclusions about the life cycle performance of Passive House and low-energy buildings.

Gustavsson and Joelsson (2010) conducted an analysis of life cycle primary energy use and carbon dioxide emissions for construction and operation phases of residential buildings in Sweden. They compared conventional and low-energy residential buildings as well as different heating and domestic hot water systems including electric resistance, ground source heat pump and district heating. Gustavsson and Joelsson (2010) confirm that as the thermal envelope of a building is improved to increase operational energy efficiency, more materials are required, thus increasing the impact of embodied energy on total life cycle energy consumption. Electric resistance heating was found to have the highest carbon emissions, followed by ground source heat pump, which had significantly less carbon emissions and finally district heat, which had slightly lower carbon emissions (Gustavsson \& Joelsson, 2010). The results also indicated that whole building embodied energy contributes $45 \%$ of the total life cycle energy of the conventional buildings assessed, rising to $60 \%$ for low-energy buildings (Ibid.).

Research by Dahlstrøm, Sørnes, Tveit Eriksen, and Hertwich (2012) compared the life cycle environmental burden of wood-framed, single-family residential buildings built to the 2010 Norwegian Building Code and the Norwegian Passive House Standard. The authors investigated four heating and hot water combinations, including: electric resistance, a combination of electric resistance $(60 \%)$ and wood (40\%), vacuum solar hot water augmented with electric resistance, and, a combination of an air-to-water heat pump (75\%) supplemented by electric resistance (25\%). Results indicated that heating with vacuum solar hot water and electric resistance produces the least life cycle $\mathrm{CO}_{2}$ equivalent emissions for the passive house envelope, followed closely by the air-to-water heat pump supplemented with electric heat (Dahlstrøm et al., 2012). The research also determined that a Passive House envelope combined with an air-to-water heat pump has life cycle energy savings of close to $40 \%$ and greenhouse gas emission reductions of $30 \%$ over a code-built house with a traditional electric resistance heating system. However, a house with a traditional building envelope and heat 
pump was found to have a similar life cycle energy burden as a Passive House with electric resistance heating (Ibid.).

Sartori and Hestnes (2007) conducted a survey of 60 case studies in nine different countries from across the world, covering conventional and low-energy building life cycle energy use. The study was limited to looking at embodied and operational energy and included both commercial and residential buildings (Sartori \& Hestnes, 2007). The study found a linear correlation between operating and total energy in all cases surveyed, showing that operational energy is the primary driver of life cycle energy use for all climates and designs. Satori and Hestnes (2007) go on to state that low-energy buildings have a net benefit on life cycle energy use despite having increased embodied energy. Additionally, buildings constructed to the Passive House Standard were found to consume three times less energy over their life cycles when compared with conventional buildings, while slightly increasing embodied energy from $1171 \mathrm{kWh} / \mathrm{m}^{2}$ to $1391 \mathrm{kWh} / \mathrm{m}^{2}$ (Ibid.). The study was limited in that not all case studies assessed indicated whether primary or end-use energy was being measured, resulting in assumed units of measure for these instances (Ibid.).

Research by Himpe et al. (2013) comparing zero-energy Passive House life cycle energy use to a standard house and a zero-energy house with a moderately performing thermal envelope was conducted for Belgian climates. Results of the study indicated that the range of life cycle embodied energy for the standard and passive house scenarios were $21-41 \mathrm{kWh} / \mathrm{m}^{2}-\mathrm{yr}$ and $27-45 \mathrm{kWh} / \mathrm{m}^{2}-\mathrm{yr}$, respectively. However, these same two buildings designed for net-zero energy use both resulted in life cycle embodied energy of $46 \mathrm{kWh} / \mathrm{m}^{2}$-yr (Himpe et al., 2013). Additionally, a comparison of the non-renewable embodied energy of timber and masonry building structures was made. The standard timber building had lower embodied energy for the construction than the passive house timber building but higher embodied energy for services. Both standard and passive house buildings with masonry structure resulted in significantly higher embodied energy (Ibid.). The findings also indicated that the largest life cycle energy savings result from selection of building materials and services based on life cycle assessment criteria. 
Himpe et al. (2013) state that the importance of life cycle embodied energy and endof-life energy increases for low-energy-buildings as their operational energy decreases. Additionally, they conclude that supplying space heating and DHW with air source heat pumps achieves the lowest embodied and end-of-life energy, followed closely by air source heat pumps combined with solar hot water and then by geothermal heat pumps (Ibid.).

Research conducted by Feist (1997) focused on defining the maximum level of energy reductions possible for German buildings implementing passive design strategies by analyzing life cycle primary energy consumption of buildings designed to various energy performance levels. The study concluded that over an 80-year assumed building lifespan, the embodied energy of passive house insulation would overtake the life cycle savings only beyond a thickness of $1050 \mathrm{~mm}$ due to the increase in energy used for manufacture of the insulation and the diminishing returns in operating energy reductions. Also, after approximately $230 \mathrm{~mm}$ of insulation, there is a drop in embodied energy due to elimination of a central heating system (Feist, 1997).

A journal article by Passer, Helmuth and Maydl (2012) assessed the life cycle energy consumption of 5 buildings in Austria, including a Passive House and lowenergy houses. Passer et al. (2012) state that life cycle assessments are important tools for ensuring that the environmental impacts of low-energy buildings are not simply shifted from the operation to the construction stage. The study results indicated that the Passive House had the lowest life cycle energy use and that the proportion of global warming potential (GWP) attributable to embodied energy of materials is 31\% (Passer et al., 2012).

A thesis by Bowick (2011) focused on creating a life cycle assessment database for new low-rise residential construction in Canada. The research scope was limited to two-storey detached, semi-detached and row houses, sized according to the average national household size reported by Statistics Canada in the 2006 census. Results of research by Bowick (2011) indicated that climate and fuel mix have the greatest influence on life cycle greenhouse gas emissions. It was also determined that for energy efficient buildings, the proportion of life cycle GWP 
attributable to embodied impacts can range from 11 to $78 \%$ for detached housing, depending on location with the highest percentage occurring in Montreal and lowest in Halifax (Bowick, 2011). Sensitivity to material and fuel use choice for detached dwellings was found to range from 344 to $1,373 \mathrm{Mg}$ CO2eq, with the highest and lowest sensitivities occurring in Calgary and Toronto, respectively. Regional electricity grid carbon intensity was identified as the primary factor influencing life cycle GWP sensitivity (Ibid.). Additionally, it was determined that designing a building for increased energy efficiency results in an increase in embodied energy due to greater use of materials such as insulation. The decreased operating energy use increases the influence that embodied energy has on the total life cycle energy consumption (Ibid.).

Existing literature covering life cycle assessment of buildings constructed to the Passive House Standard and other low energy building standards has primarily focused on the European context. One of the common conclusions drawn is that embodied energy and by extension the carbon emissions of low energy buildings, generally make up a significant proportion of the total life cycle impact. However, the majority of this research fails to quantify the proportion of life cycle emissions attributable to the increased envelope insulation and indirect supporting components. Factors identified to have a major influence on life cycle impact include: climate, energy supply mix carbon intensity, mechanical system efficiency, and carbon intensity of building materials. Literature by Sartori and Hestnes (2007) and Passer et al. (2012) concluded that low energy and Passive House buildings have net life cycle benefits over conventional construction, while other research claims that certain configurations of envelope and mechanical systems result in similar life cycle impacts as conventional buildings (Dahlstrøm et al., 2012). Contradictory findings reported in the literature are likely due to the prevalent use of case studies. Currently, little research has been conducted using modeling to isolate the influence that the various parameters have. This could yield insight into the sensitivity of building life cycle emissions to the embodied effects of building materials and energy supply mix carbon intensities. 


\section{Problem Definition and Research Questions}

\subsection{Objective and Justification}

The problem statement driving the research is defined as follows: The Passive House Standard offers a building physics based method for achieving large reductions in building operating energy consumption and mitigating climate change by reducing greenhouse gas emissions (PHIUS, 2013a). The standard includes specifically defined energy intensity targets covering annual heating and cooling demand, peak heating load and annual primary energy demand. These intensity targets are constant across all climates, countries, and geographic regions within countries. Additionally, a single set of primary energy and carbon emission factors are applied to the entire North American continent, irrespective of regional differences in energy carbon intensity. Therefore, the standard cannot be considered reliable for quantifying Passive House life cycle operating greenhouse gas emissions. Finally, the standard lacks consideration of embodied GWP impacts, thus ignoring a potentially significant portion of the total life cycle climate impact of passive buildings. Therefore a need exists for a method to assist designers in selecting a balanced combination of insulation and mechanical system fuel source to minimize the GWP impact of buildings.

\subsection{Research Questions}

The research addresses the following questions arising from the problem statement:

1. How do insulation thickness and material choice influence envelope GWP?

2. What are the relationships between location, mechanical system fuel type and life cycle GWP?

3. How does the Passive House Standard method of predicting GWP compare to a method taking into account region specific electricity carbon intensity? 


\subsection{Scope and Limitations}

The proposed research scope was limited to investigating the impact of the following variables on the life cycle GWP of a building designed to the Passive House Standard: (i) changing location, (ii) building envelope insulation thickness and material type, and (iii) mechanical system fuel type. Building envelope thickness and space conditioning systems were sized to meet the building energy performance criteria of the Passive House Standard shown in Table 2-1. It was assumed that the remaining components of the standard under the "elemental performance requirements", "services performance" and "acoustic performance" criteria headings were met. Investigation of the impact that variations in occupant behaviour have on building energy use was beyond the scope of this study.

This study did not examine all of the aspects of life cycle GWP, but rather focused on a comparative assessment of the impact that envelope choices have on both embodied and operating GWP. The primary reason for this focus stems from the lack of literature evaluating the net life cycle carbon impacts of Passive House building envelopes. Elements highlighted in blue in Figure 3-1, were included in this study. Variables assessed in this study are also indicated on the Figure, which included space conditioning and opaque envelope elements. Grey-shaded elements, all of which fall under embodied impacts, represent variables excluded due to limitations of the chosen life cycle modeling tool. Embodied GWP impacts not evaluated include: mechanical systems, appliances, internal structure, and interior finishes. Additionally, transparent envelope elements were excluded from the embodied GWP assessment due to a lack of data specific to insulated glazing products suitable for use in passive buildings. Whole-building energy performance modeling was conducted for each case to generate annual energy consumption data for input into the life cycle assessment software. The life cycle assessment component of the research was limited to quantification of GWP in terms of carbon equivalent emissions $\left(\mathrm{CO}_{2} \mathrm{eq}\right)$, since climate change mitigation is the stated objective of the Passive House Standard. 


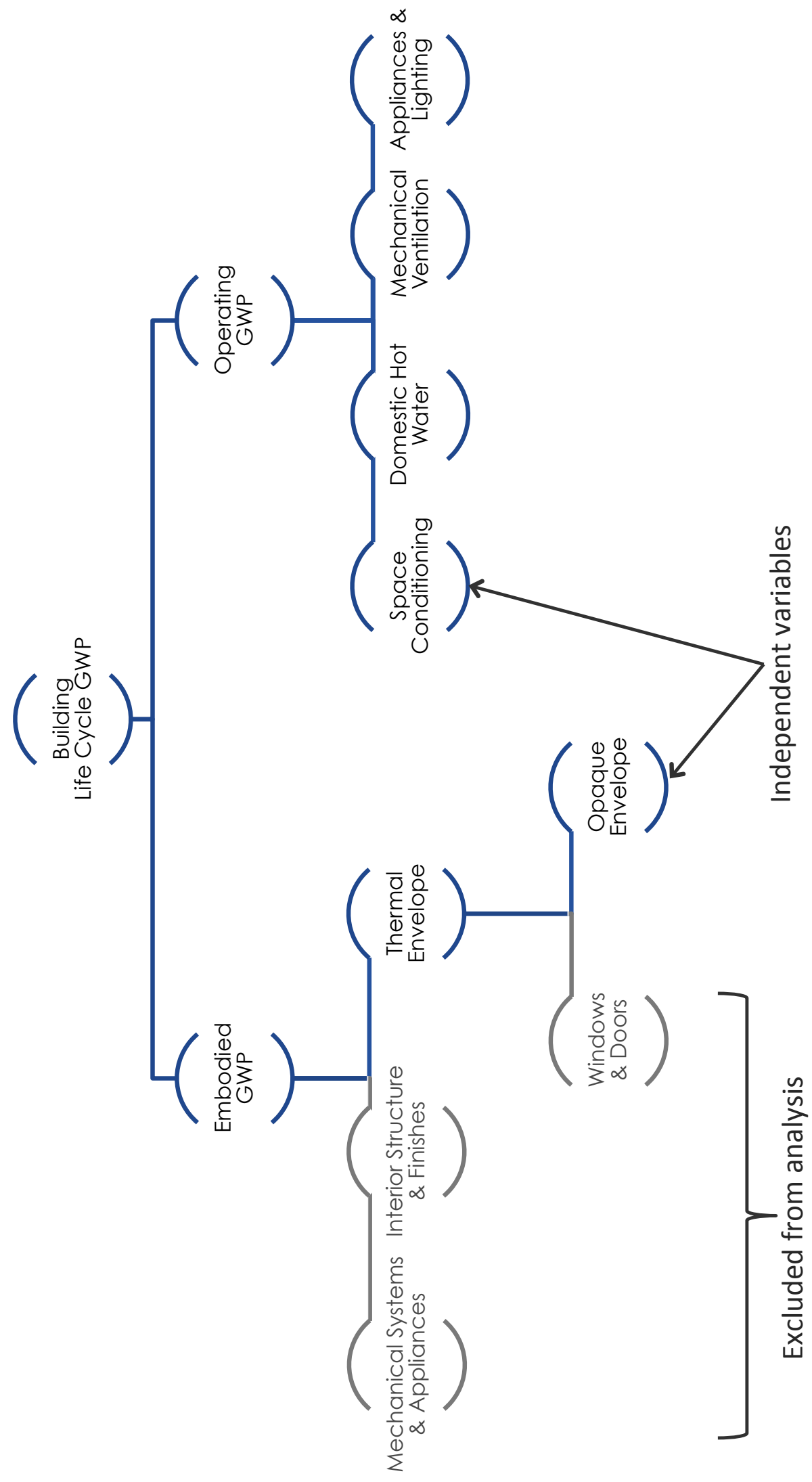

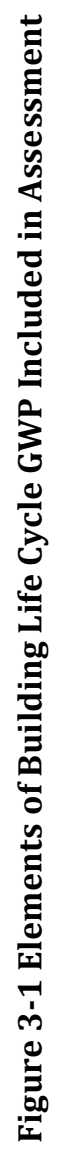


This study was limited to investigation of a single-family detached reference building, since the Passive House Standard is most difficult to achieve with this building typology (Cotterell \& Dadeby, 2012). Although the level of insulation attainable would also be dependent on financial factors, the research did not address economic considerations. Rather, the study focused on technological feasibility with the intent that the findings could provide a basis for future research to address economic concerns. Finally, the study did not address the life cycle impact of deploying onsite renewable electricity generation, since the Passive House Standard does not currently allow the use of onsite generated electricity to meet the annual primary energy demand criteria. However, both the German based Passive House Institute and the Passive House Institute U.S. are currently developing changes to their standards to recognize the importance of onsite renewable electricity generation in reducing GWP (Wright, Klingenberg, \& Pettit, 2014; Wünsch, 2014). Therefore, this may well become a topic of further research in the future. 


\section{Research Approach}

\subsection{Research Method Overview}

This Section deals with the methods developed to test the research questions previously posed in Section 3.2 (p. 9). The process flow diagram in Figure 4-1 provides an overview of the methods used in this study.

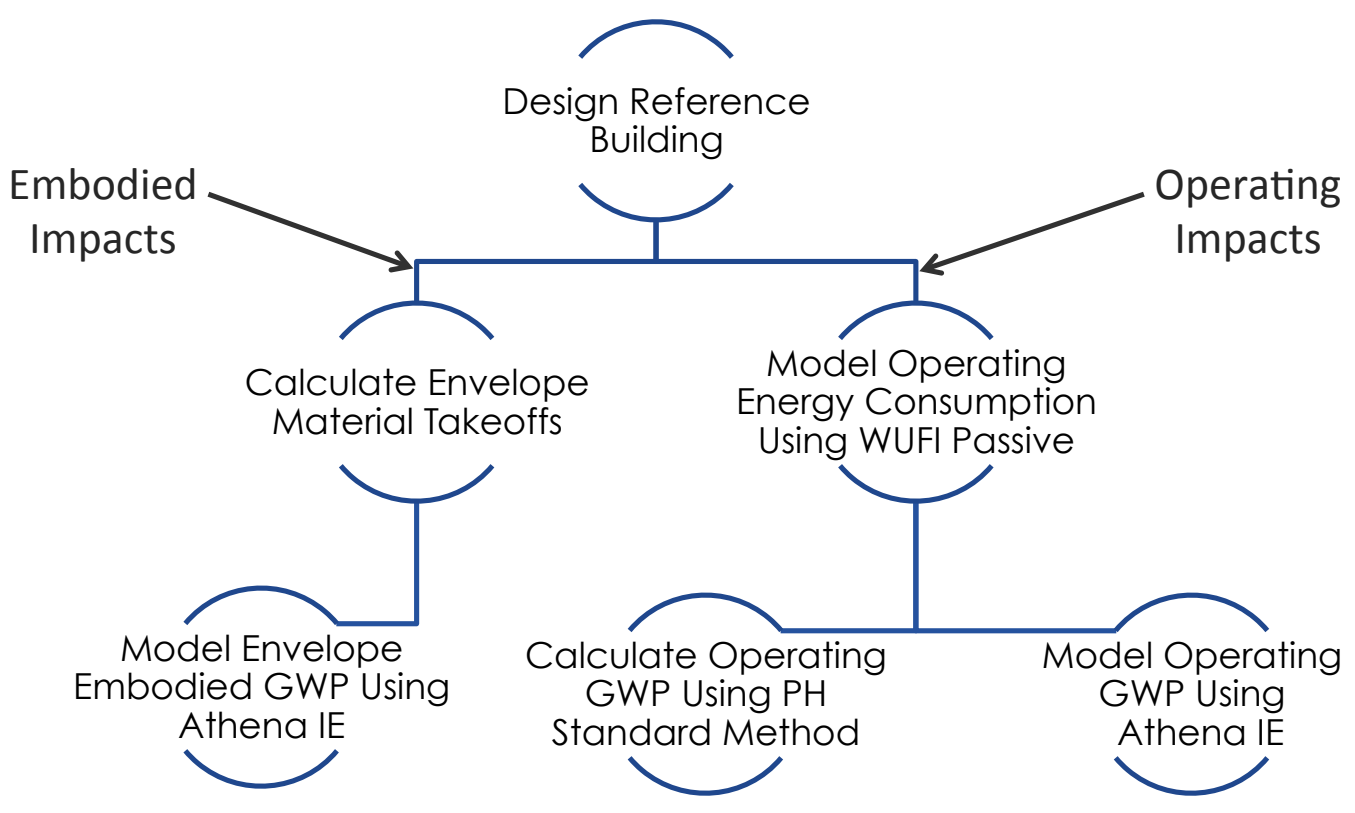

Figure 4-1 Overview of Research Methods

A reference building was designed according to passive house principles to test the impact of changing various envelope and mechanical system parameters on embodied and operating life cycle carbon emissions. A complete description of the process used to develop the reference building is covered in Section 4.2 (p. 15), including the rationale behind selecting two mechanical system cases for analysis. A whole building energy model of the reference building was created using WUFI Passive, a software program capable of determining the operating energy consumption in accordance with the Passive House Standard. An overview of the 
whole building energy model is provided in Section 4.3 (p. 30), while Appendix A covers the detailed inputs and assumptions used to construct the reference building model.

A life cycle carbon impact model of the reference building was created using Athena Impact Estimator software to both evaluate envelope embodied GWP and assess operating GWP based on energy consumption data obtained from the whole building energy model. The methods used and assumptions made are presented in Section 4.4 (p. 32), with specific inputs and calculations for material take-offs provided in Appendix B.

Section 4.5 (p. 34) covers the procedure used to assess reference building GWP for two different mechanical system cases and three separate Canadian locations. Methods used to assess reference building envelope embodied GWP impacts are covered in Section 4.5 .1 (p. 34), which includes evaluation of different envelope materials to determine a range of impact. Section 4.5 .2 (p. 37) describes a procedure used to model reference building operating GWP that accounts for regional variations in electricity grid carbon intensity. Operating GWP results were compared for different locations and mechanical systems to understand the relationship between these parameters and to later determine whether the regional approach for determining operating GWP is justified. Section 4.5 .3 (p. 38) details the process used to evaluate the significance of envelope embodied GWP in relation to operating GWP for each permutation of location and mechanical system type. The method used to compare results of the regional based operating GWP to emissions predicted by the calculation method of the Passive House Standard is presented in Section 4.5.4 (p. 39).

Section 4.6 (p. 42) covers the development of a parametric model used to test the impact that varying envelope insulation thickness has on embodied and operating carbon emissions. The embodied GWP component of the parametric model, described in Section 4.6 .1 (p. 42), covers three assembly material configurations representing different insulation and wall cladding material types. Section 4.6 .2 (p. 46) details the procedure used to assess the net impact of varying 
insulation thickness on life cycle carbon emissions, and to determine the influence of location and mechanical system selection.

Envelope scenarios optimized for life cycle GWP were generated to evaluate the relationship between annual heat demand and life cycle GWP, as described in Section 4.7 (p. 48). Three types of scenarios were evaluated for each location and mechanical system type, which included: "reasonable" low carbon scenarios that account for diminishing reductions in life cycle GWP with increasing insulation; life cycle GWP optimized envelope scenarios meeting the Passive House Standard annual heat demand criterion, and reference building envelope scenarios. The method used for selecting "reasonable" building envelope scenarios, is presented in Section 4.7.1 (p. 48), while the method used for selecting Passive House building envelopes optimized for life cycle GWP is described in Section 4.7.2 (p. 49). The procedure implemented to analyze the relationship between annual heating demand and life cycle GWP in different climates and for different mechanical system types, is detailed in Section 4.7.3 (p. 52).

\subsection{Reference Building Design}

\subsubsection{Building Typology}

A reference building was developed to model the life cycle performance of different building envelope scenarios. A single detached house was selected since it represents the most difficult typology for meeting the Passive House Standard. This is due the detached typology having a larger number of exposed walls compared to semi-detached and row housing, therefore resulting in a higher rate of heat loss. Additionally, this typology represents over half of the residential building stock in terms of dwelling units and $67 \%$ of total constructed floor area (Natural Resources Canada, 2014). To ensure that the design was relevant to the Canadian context, the reference building was based on the Canadian average household dwelling area of $167 \mathrm{~m}^{2}$ (Table 4-1). The dwelling area was calculated based on data for all Canadian single detached homes existing up to 2010. 
Table 4-1 National and Provincial Average Detached Dwelling Household Size and Area

\begin{tabular}{|c|c|c|}
\hline \multirow[t]{2}{*}{ Province } & \multicolumn{2}{|l|}{ Detached Dwellings } \\
\hline & Persons/dwelling ${ }^{a}$ & Area $\left(\mathrm{m}^{2} / \mathrm{dwelling}\right)^{\mathrm{b}}$ \\
\hline$A B$ & 2.9 & 157 \\
\hline ON & 2.9 & 179 \\
\hline QC & 2.7 & 138 \\
\hline Canada Average & 2.8 & 167 \\
\hline $\begin{array}{l}\text { Notes: } \\
\text { a Source: Statisti } \\
\text { b Source: Natural }\end{array}$ & $\begin{array}{l}\text { cs Canada, } 2011 \\
\text { I Resources Canada } 2\end{array}$ & \\
\hline
\end{tabular}

\subsubsection{Geographic Locations}

Geographic locations selected for assessment were required to reflect three different climates and three different electricity grid greenhouse gas intensities. Additionally, only large Canadian population centres were considered, since this increased the likelihood of procuring the necessary data to conduct the analyses. The three locations selected were represented by the cities of Toronto, Montreal, and Edmonton. Climates were compared based on the number of heating degreedays, as indicated in Table 4-2, while the electricity grid for each location was compared based on the carbon dioxide equivalent greenhouse gas emissions per kWh of electricity consumed, as summarized in Table 4-3.

Table 4-2 - Subject Location Climate Factors

\begin{tabular}{|l|rr|}
\hline \multirow{2}{*}{ Location } & \multicolumn{2}{|c|}{ Climate Factors } \\
\cline { 2 - 3 } & Heating Degree Days & Cooling Degree Days \\
\hline Toronto Pearson International Airport & 3873 & 305 \\
Montreal Trudeau International Airport & 4363 & 271 \\
Edmonton International Airport & 5637 \\
\hline Notes: & & 32 \\
\hline Data from Environment Canada (2014a) & \\
\hline
\end{tabular}


Table 4-3 Electricity Generation Carbon Intensity by Province

\begin{tabular}{|l|rrrrrrrr|}
\hline \multirow{2}{*}{ Province } & \multicolumn{8}{|c|}{ Historic Electricity Generation Carbon Intensity ${ }^{\mathbf{1}}$} \\
& (g CO $_{\mathbf{2}}$ eq/kWh) \\
\hline \multicolumn{1}{|c|}{ Year } & 1990 & $\mathbf{2 0 0 0}$ & $\mathbf{2 0 0 5}$ & $\mathbf{2 0 0 8}$ & $\mathbf{2 0 0 9}$ & $\mathbf{2 0 1 0}$ & $\mathbf{2 0 1 1}$ & $\mathbf{2 0 1 2}$ \\
\hline Ontario & 220 & 320 & 240 & 170 & 120 & 150 & 100 & 110 \\
Quebec & 14.0 & 4.0 & 4.1 & 2.9 & 4.0 & 2.9 & 2.6 & 3.6 \\
Alberta & 1000 & 1000 & 980 & 1200 & 1100 & 1000 & 1000 & 910 \\
\hline Notes: \\
\hline${ }^{1}$ Values obtained from Environment Canada (2014b). \\
\hline
\end{tabular}

\subsubsection{Site Characteristics}

Site characteristics represent factors external to the building envelope, including climate, lot size, lot orientation and shading objects not attached to the building. Microclimate factors were not considered in the design of the reference building. Lot characteristics were assumed to allow for optimal solar south orientation, with no shading from trees or neighbouring buildings present, representing an idealized situation for Passive House design.

\subsubsection{Building Geometry and Orientation}

The reference building was designed to Passive House specifications while representing the average floor area of Canadian single-detached dwellings. This required several assumptions to be made about the building geometry and site orientation.

A square footprint and two-storey layout were selected to adhere to the Passive House design strategy of maintaining a compact building shape. A simplified building layout and geometry maximize the internal volume to floor area ratio, thereby reducing heat loss. Trade-offs are often made between compactness and increased solar gains when designing passive homes for a specific location, typically resulting in a rectangular building shape with the wider façade oriented east-west for maximized southern exposure. However, this would have resulted in a performance bias for a certain location. Therefore, a priority was given to 
compactness over solar gains. The geometry and layout of the reference building was kept constant across all three locations.

The reference building floor area was calculated from exterior envelope dimensions, as per accepted standards for detached dwellings in Ontario (Tarion, 1990). However, the Passive House Standard uses interior-based floor areas to calculate energy intensity criteria and ventilation system energy consumption. Therefore, to enable a direct comparison of building performance for different envelope insulation thicknesses, all adjustments to wall assembly dimensions were made with respect to the interior wall surface. Since there was no change between first and second storey floor plates, each storey represented half of the average Canadian floor area (i.e. $83.5 \mathrm{~m}^{2}$ ).

\subsubsection{Building Envelope}

The reference house was developed based on the envelope assemblies of the Dublin Passive House, a certified Passive House located in Urbana, Illinois, representative of a cold continental climate. The Dublin Passive House is a wood framed building with a slab on grade foundation and gabled roof. This building was selected due to the availability of a whole building energy model in WUFI Passive, with input parameters verified by PHIUS.

The reference building envelope was designed with materials and assemblies that have been used in cold climate Passive House design and are widely available in the Canadian market. Insulation for the walls and roof consist of blown-in cellulose, while expanded polystyrene (EPS) was selected as insulation for the slab assembly. The reference building envelope wall sections are presented in Figure 4-2 and assembly thermal properties are summarized in Table 4-4. 
Table 4-4 Reference Building Envelope Properties

\begin{tabular}{|c|c|c|c|c|c|c|c|c|}
\hline \multicolumn{3}{|c|}{ Wall } & \multicolumn{3}{|c|}{ Roof } & \multicolumn{3}{|c|}{ Slab } \\
\hline $\begin{array}{l}\text { Insulation } \\
\text { Material }\end{array}$ & $\begin{array}{l}\text { Insulation } \\
\text { Thickness } \\
(\mathrm{mm})\end{array}$ & $\begin{array}{l}\text { Total } \\
\text { Assembly } \\
\text { RSI-value } \\
\left(\mathrm{m}^{2}-\mathrm{K} / \mathrm{W}\right)\end{array}$ & $\begin{array}{l}\text { Insulation } \\
\text { Material }\end{array}$ & $\begin{array}{l}\text { Insulation } \\
\text { Thickness } \\
(\mathrm{mm})\end{array}$ & $\begin{array}{l}\text { Total } \\
\text { Assembly } \\
\text { RSI-value } \\
\left(\mathrm{m}^{2}-\mathrm{K} / \mathrm{W}\right)\end{array}$ & $\begin{array}{l}\text { Insulation } \\
\text { Material }\end{array}$ & $\begin{array}{l}\text { Insulation } \\
\text { Thickness } \\
(\mathrm{mm})\end{array}$ & $\begin{array}{l}\text { Total } \\
\text { Assembly } \\
\text { RSI-value } \\
\left(\mathrm{m}^{2}-\mathrm{K} / \mathrm{W}\right)\end{array}$ \\
\hline $\begin{array}{l}\text { Blown-in } \\
\text { Cellulose }\end{array}$ & 394 & 102 & Blown-in & 640 & 17 & EPS & 25 & 72 \\
\hline
\end{tabular}




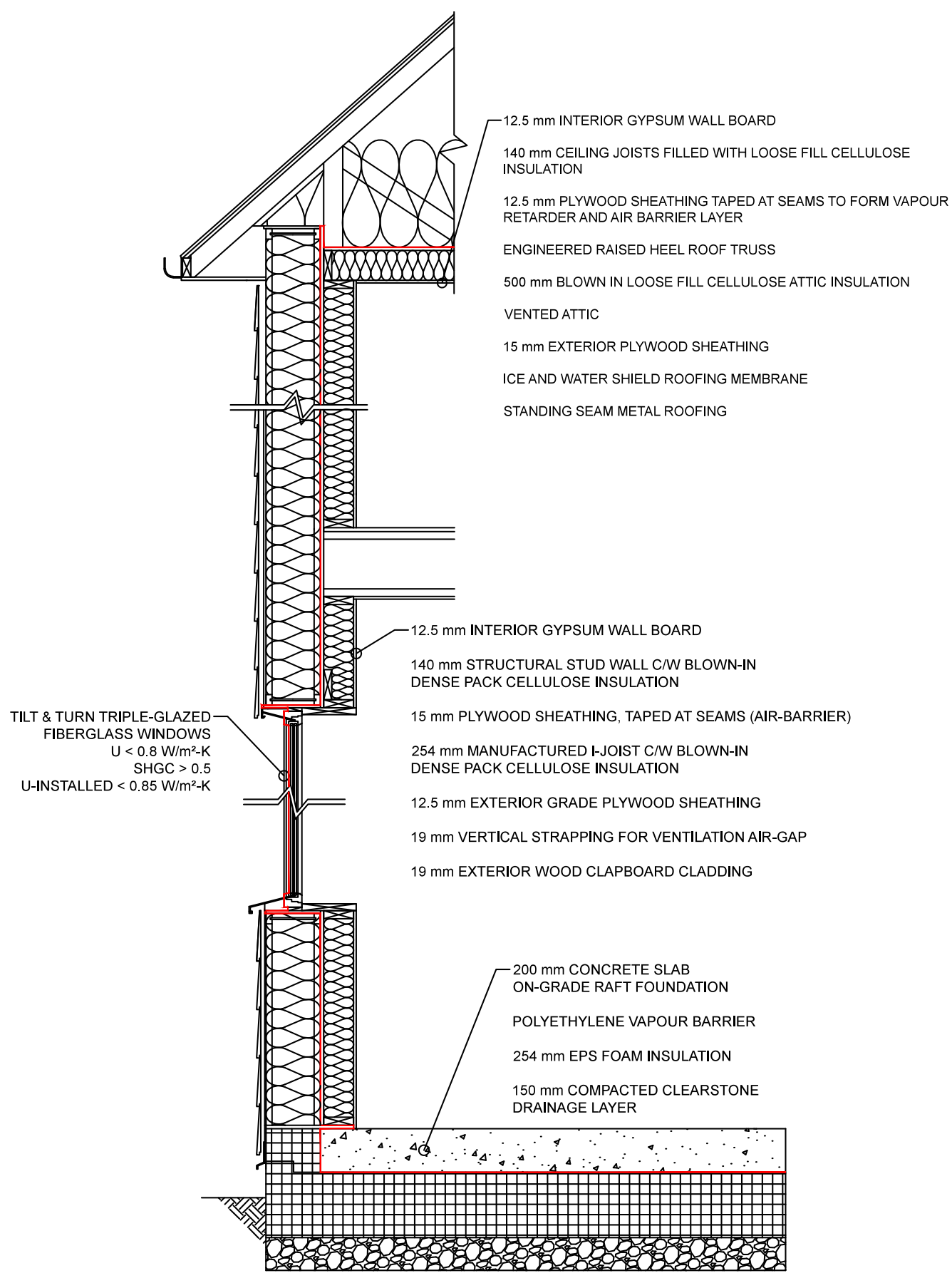

Figure 4-2 Test House Reference Building Wall Section (adapted from PHIUS, 2013a) 


\subsubsection{Reference Building Floor Plans}

Basic floor plans were drawn to provide a reference for placement of windows, mechanical system ductwork and pipe layouts. Floor plans were also used to calculate the treated floor area as required for evaluation of building energy performance against the Passive House Standard. Test house floor plans are provided in Figure 4-3 and Figure 4-4. 


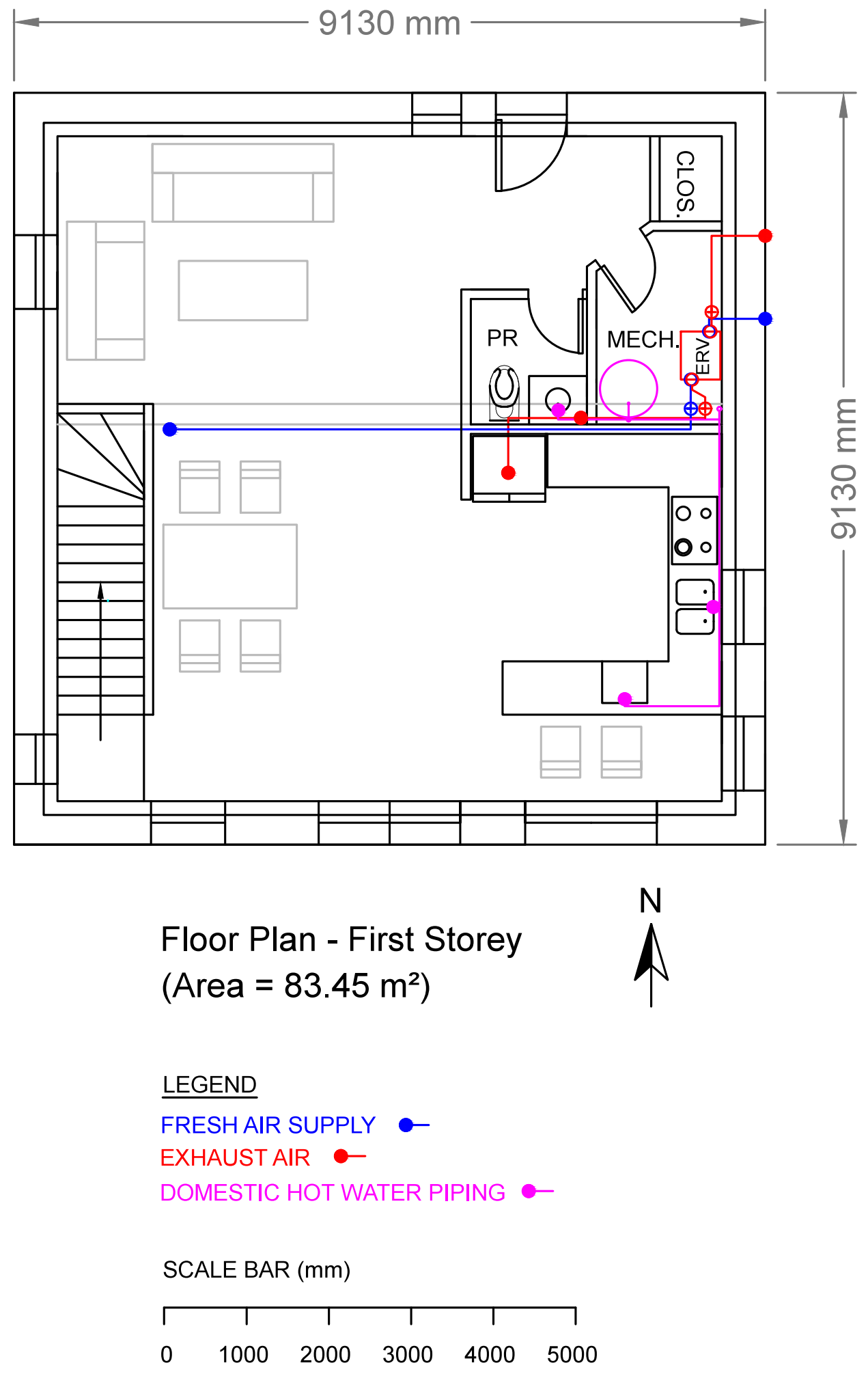

Figure 4-3 Test House First Storey Floor Plan and Mechanical System Layout 

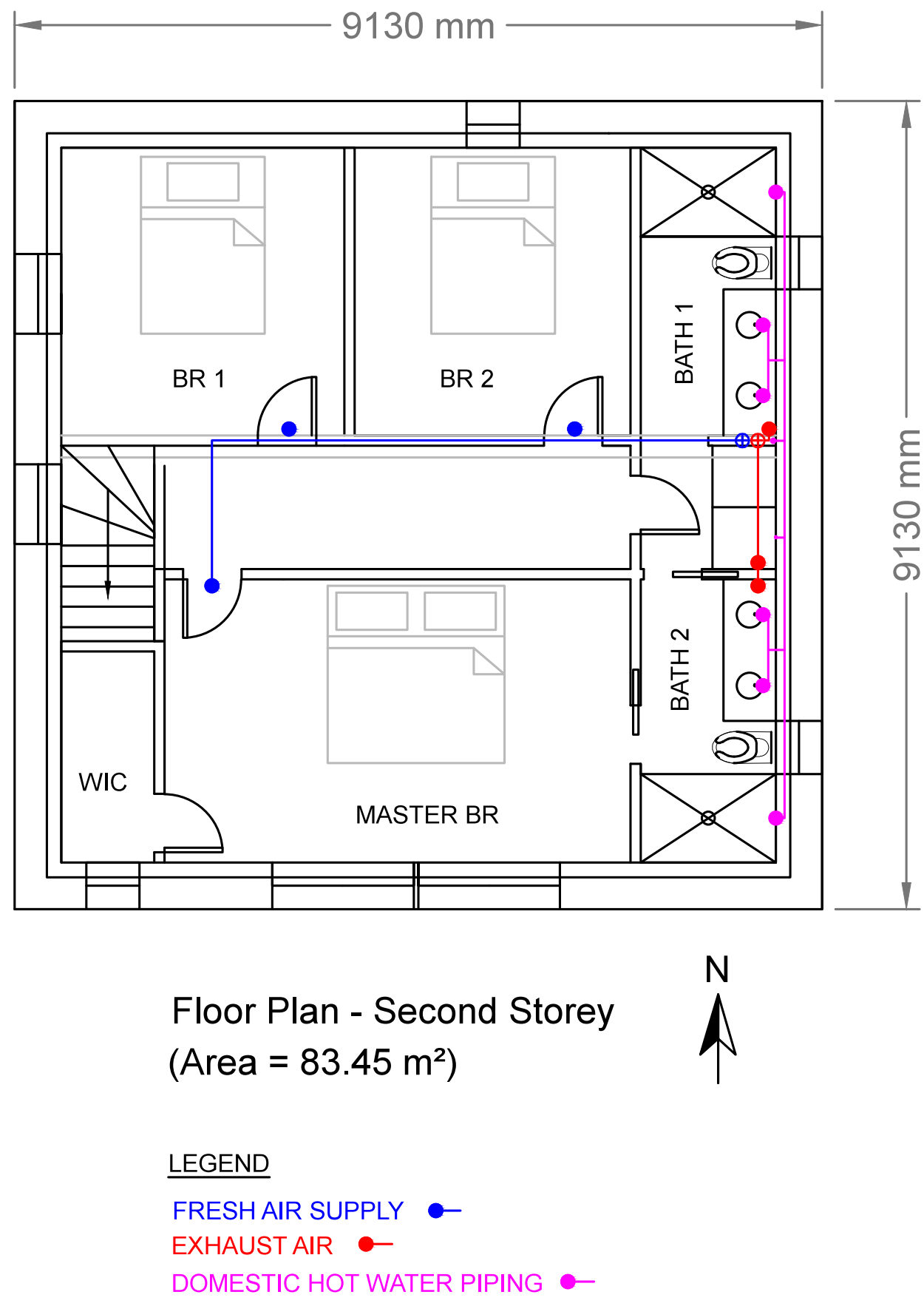

SCALE BAR (mm)

\begin{tabular}{cc|c|c|c|c|}
\hline & $\mid$ & & & $\mid$ & \\
0 & 1000 & 2000 & 3000 & 4000 & 5000
\end{tabular}

Figure 4-4 Test House Second Storey Floor Plan and Mechanical System Layout 


\subsubsection{Thermal Bridging}

It was assumed that thermal bridging would be negligible since the reference building is based on the Dublin Passive House, which was designed to minimize thermal bridging (PHIUS, 2013a). Therefore, a 2-dimensional thermal bridge analysis was not conducted for assembly details.

\subsubsection{Glazing size and orientation}

Passive House design principles were followed when sizing windows for each façade. Several large windows located on the south-facing facade were oriented to offset some of the heat demand. Fewer windows on the west façade helped to reduce overheating, while limiting north-facing glazing to just two small windows reduced the overall envelope heat-loss.

High performance triple-paned windows are a requirement when designing a Passive House for Canadian climates. PHIUS certified Alpen 725 series (PHIUS, 2014b) windows were selected due to the availability of data for input into WUFI Passive. These windows had low U-values to limit heat loss and sufficient solar heat gain coefficient values to allow solar radiation into the house. The insulated glazing unit (IGU) constructions are available in a variety of configurations, allowing tuning of the glazing solar heat gain coefficients (SHGC) based on window orientation. Windows with lower SHGCs also tend to have lower U-values, which help to reduce heat loss through the IGU. A summary of window properties specified for the reference building is provided in Table 4-5. North, West, East, and South elevation drawings, including window numbers corresponding to those in Table 4-5 are presented in Figure 4-5, Figure 4-6, Figure 4-7, and Figure 4-8, respectively. 
Table 4-5 Summary of Test House Window Properties

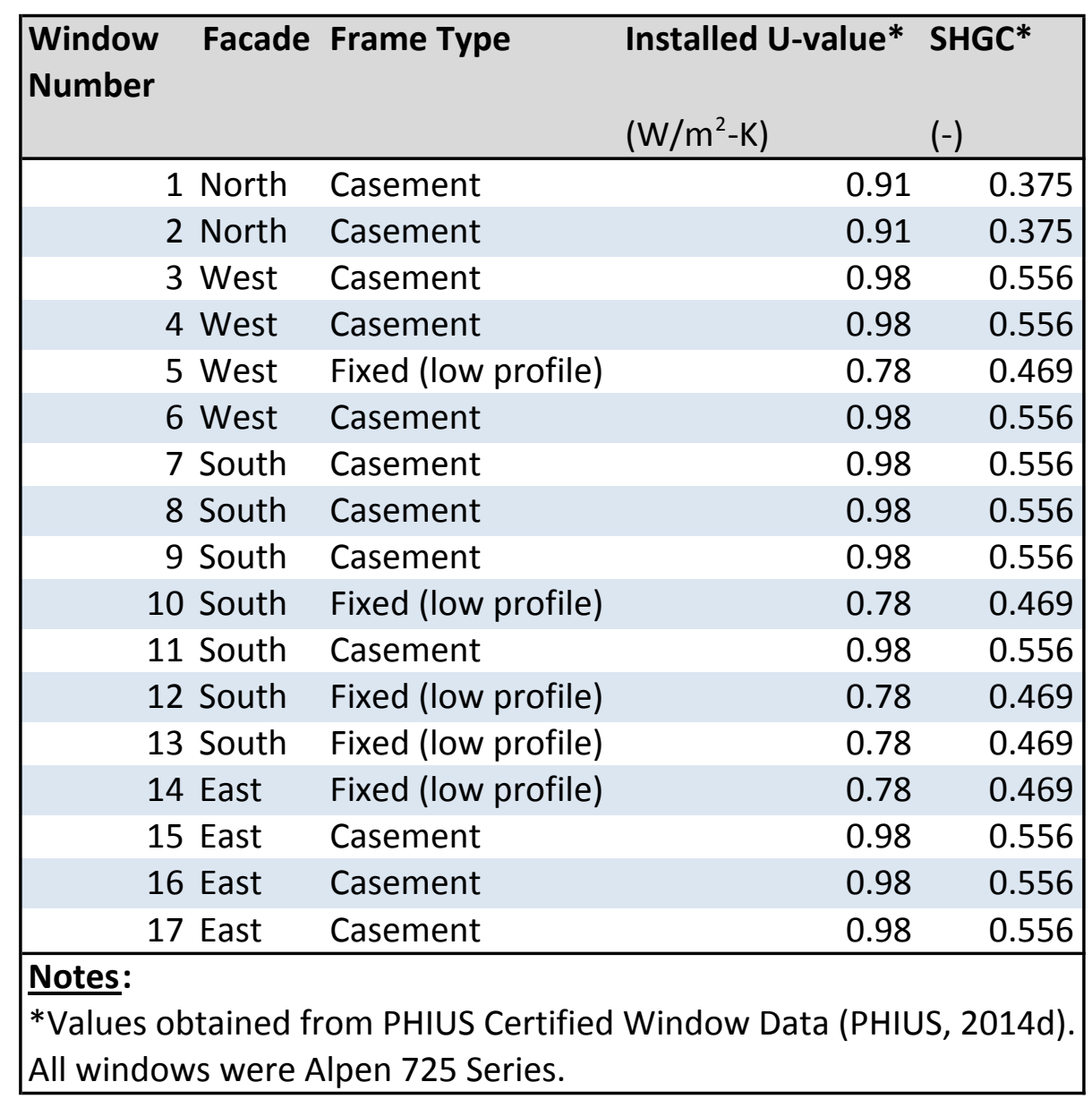




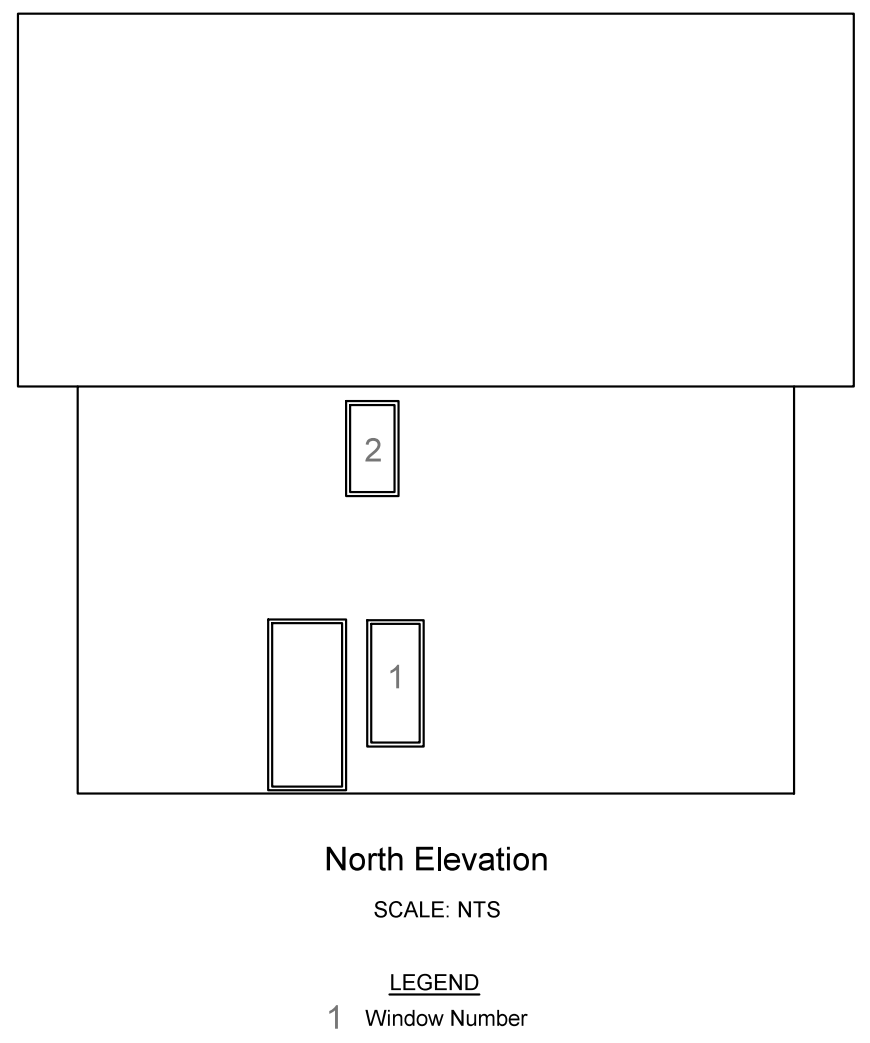

Figure 4-5 Reference Building North Elevation

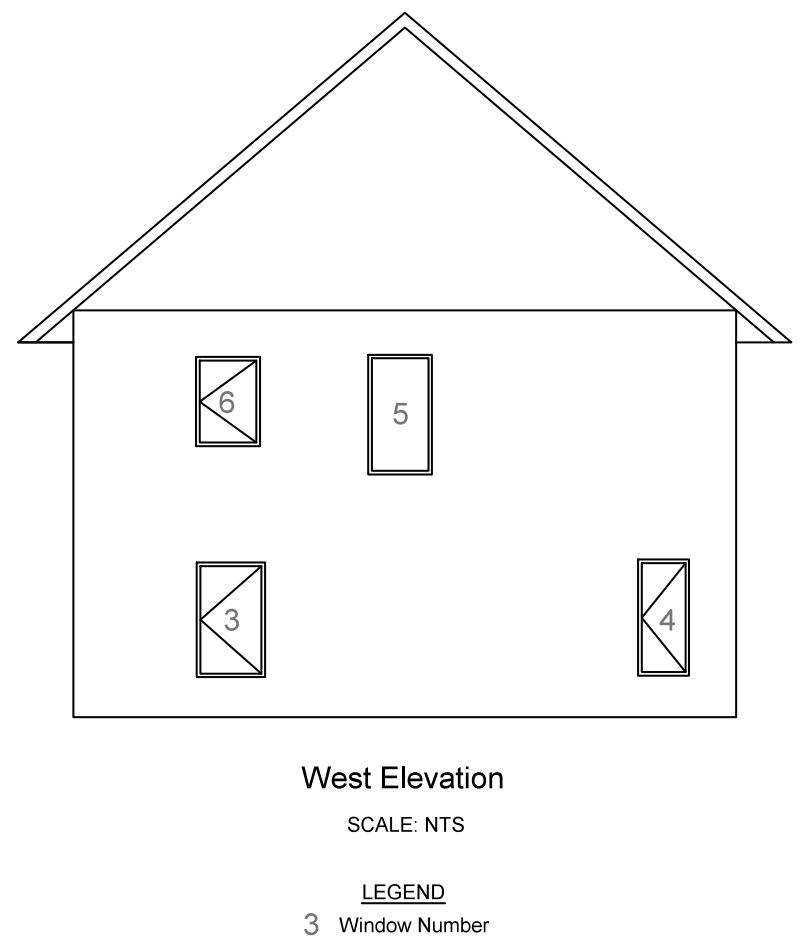

Figure 4-6 Reference Building West Elevation 


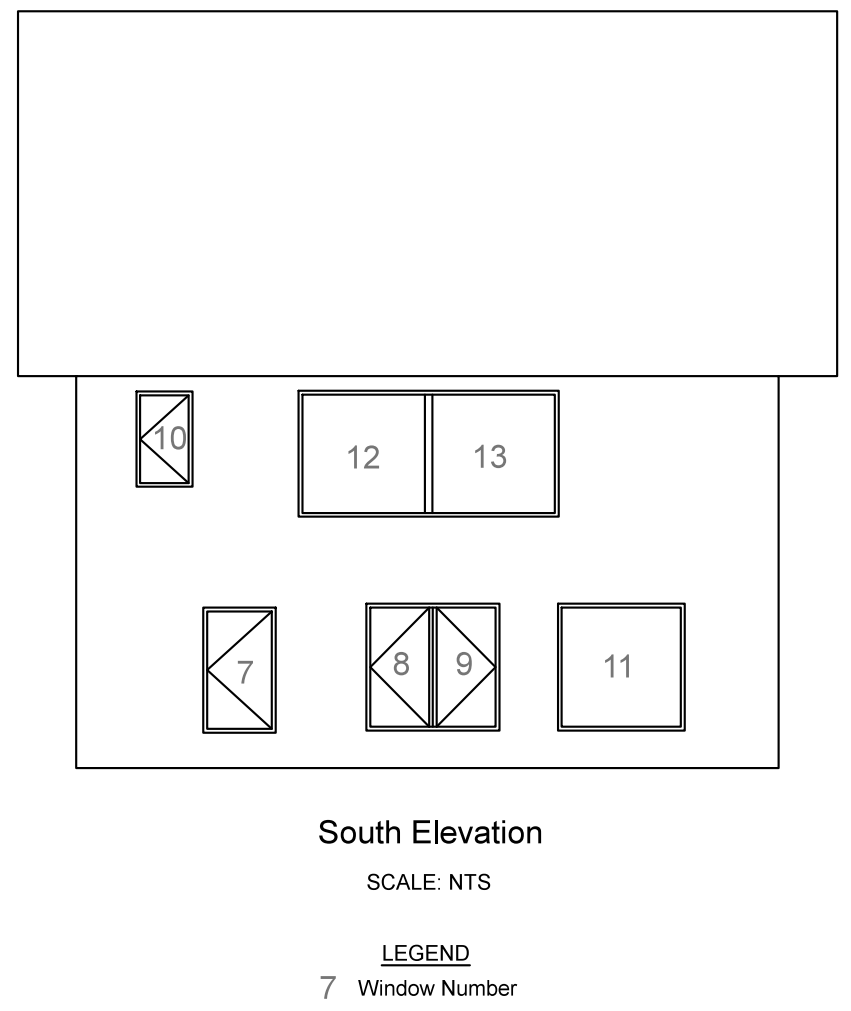

Figure 4-7 Reference Building South Elevation

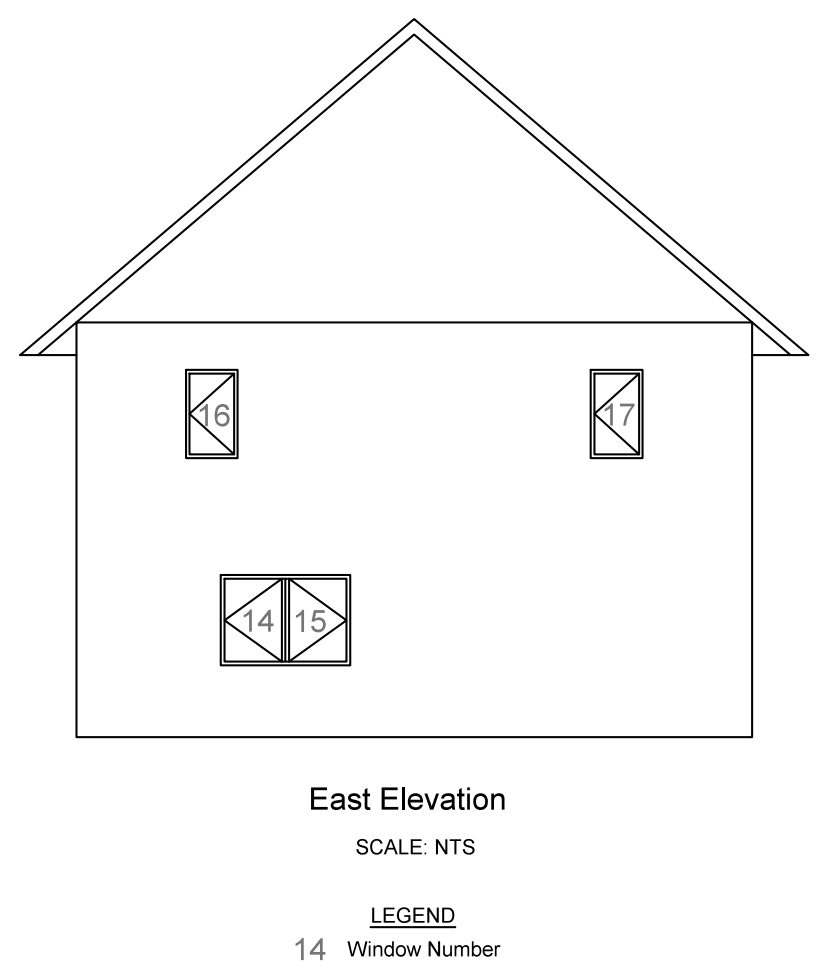

Figure 4-8 Reference Building East Elevation 


\subsubsection{Doors}

A high-performance, thermally broken exterior entry door was selected in accordance with Passive House design principles. Only one North American manufacturer was found that produces doors with sufficient thermal properties to meet the Passive House Standard. A summary of the manufacturer's properties for the selected door is provided in Table 4-6.

Table 4-6 Summary of Test House Door Properties

\begin{tabular}{|c|c|c|c|c|c|}
\hline $\begin{array}{l}\text { Door } \\
\text { Number }\end{array}$ & Facade & Manufacturer & Type & $\begin{array}{l}\text { Area } \\
\left(\mathrm{m}^{2}\right)\end{array}$ & $\begin{array}{l}\text { U-value } \\
\left(W / m^{2}-K\right)\end{array}$ \\
\hline & 1 North & Hammer \& Hand & Vacuum Insulated Panel & 1.8 & 0.33 \\
\hline
\end{tabular}

\subsubsection{Ventilation System}

High efficiency ventilation heat recovery is a requirement for meeting the Passive House Standard. The Passive House Standard criterion for minimum ventilation system efficiency is $75 \%$ for units tested by the international Passive House Institute (Table 2-1). High efficiency ventilation systems can be divided into two categories: heat recovery ventilators (HRVs) and energy (or enthalpy) recovery ventilators (ERVs). ERVs offer the added benefit of recovering a fraction of the latent heat from water vapour in the air to increase the efficiency. Although there are several manufacturers and products available on the Canadian market, the Ultimate Air RecoupAerator 200 DX ERV was selected. This was based on the unit's popularity for North American Passive House applications and due to the high recovery efficiency compared with other North American products.

\subsubsection{Heating, Cooling and Domestic Hot Water Systems}

Passive house heating systems are not restricted by heating system type, but rather must be accounted for in the $120 \mathrm{kWh} / \mathrm{m}^{2}$-year primary energy demand (PED) intensity criterion set out by the Passive House Standard. This criterion limits the amount of source energy that can be used to operate the building, including energy 
used for space conditioning. This allows the use of systems with different fuel types having different carbon intensities. In order to take into account the potential variation in operating GWP, two heating systems representing the two most popular fuel types in Canada were modeled. For 2011, the two most commonly used heating fuels were natural gas (50\%) and electricity (36\%) (Natural Resources Canada, 2014). Table 4-7 provides a summary of equipment used for the two mechanical systems.

Table 4-7 Summary of Mechanical System Equipment

\begin{tabular}{|c|c|c|c|c|c|c|}
\hline Equipment No & D. Type & Manufacturer & Model Name & $\begin{array}{l}\text { Space } \\
\text { Heating }\end{array}$ & DHW & $\begin{array}{l}\text { Space } \\
\text { Cooling }\end{array}$ \\
\hline \multicolumn{7}{|l|}{ Case A } \\
\hline & 1 Boiler & Viessmann & Vitodens 222-F 19 & $\mathrm{x}$ & $\mathrm{x}$ & \\
\hline & 2 Heat Pump & Mitsubishi Mr. Slim & MSZ-GEO9NA & & & $\mathrm{x}$ \\
\hline \multicolumn{7}{|l|}{ Case B } \\
\hline & 1 Electric heating & Baseboard resistance heater & Not specified & $\mathrm{x}$ & & \\
\hline & 2 Heat Pump & Mitsubishi Mr. Slim & MSZ-GEO9NA & $\mathrm{x}$ & & $\mathrm{x}$ \\
\hline & 3 Heat Pump & GE GeoSpring & GEH50DNSRSA & & $\mathrm{x}$ & \\
\hline
\end{tabular}

Case A (NG): A Viessmann natural gas fired boiler was selected for space heating due to the efficiency of the unit and its ability to also supply domestic hot water. A high efficiency Mitsubishi electric heat pump was selected to supply cooling. An electric cooling system was selected, since no widely available product capable of delivering cooling from natural gas existed on the market.

Case B (Electric): A Mitsubishi mini-split electric air-to-air heat pump system was selected because of the high efficiency of the unit and the popularity of these systems for North American Passive Houses. The heat pump was also capable of supplying space cooling. A GE electric air-to-water heat pump was selected to provide domestic hot water, due to its high efficiency relative to standard electric water heaters. 


\subsection{Whole Building Energy Model}

Whole building energy modeling was used to evaluate annual operating energy consumption of the reference building for each permutation of location and mechanical system case. A total of 6 models were created. Energy consumption data was then used to provide input values to conduct further analyses, as described in Section 4.4. This section discusses the software used, along with the assumptions made and parameters input into the software to set up the whole building energy models.

\subsubsection{Whole Building Energy Modeling Software}

Whole building energy modeling was conducted using the software WUFI Passive (Fraunhofer Institute for Building Physics, 2012). This software was developed as a result of collaboration between PHIUS, the Fraunhofer Institute for Building Physics and Owens Corning (PHIUS, 2013b). WUFI Passive was selected because it is the first building energy performance simulation software accepted for Passive House design certification specifically developed for use in North American climates. The software allows for buildings to be easily modeled and modified using a third party CAD program - Trimble Sketchup.

\subsubsection{Weather Data}

WUFI Passive accepts climate data that is either manually entered or loaded into the software from a pre-formatted file. Climate data for the select cities was acquired from PHIUS in both .XLS and .WAC file formats suitable for simulation in WUFI Passive. PHIUS processes global climate data from METEONORM into a format that is useable with WUFI Passive (PHIUS, 2013b). METEONORM is a software program from METEOTEST that uses spatial interpolation to provide climate data for any location in the world (METEOTEST, 2014). 


\subsubsection{Metrics for Assessment}

HVAC energy intensity is obtained from the WUFI Passive model and is used to determine annual site electricity ( $\mathrm{kWh} /$ year) and gas demand $\left(\mathrm{m}^{3} /\right.$ year) for input into the Athena IE life cycle model. Annual heating demand intensity ( $\mathrm{kWh} / \mathrm{m}^{2}$-yr) is used to compare the performance of three envelope scenarios with respect to the Passive House Standard criteria for annual heating demand intensity of $15 \mathrm{kWh} / \mathrm{m}^{2-}$ yr.

\subsubsection{WUFI Passive Modeling Procedure \& Assumptions}

A full description of WUFI Passive modeling procedure, including input parameters, assumptions and their justification is provided in Appendix A. The following list provides a summary of the procedure used to set up the whole building energy model.

An exterior shell model of the reference building was created using Trimble Sketchup 8 and imported into WUFI Passive. Window and door openings were then drawn and defined in WUFI Passive. Full assembly sections for each assembly case were created in WUFI Passive, including insulation and structural materials such as studs and I-joist components, as described in Section 4.2 .5 (p. 18). Assembly materials were defined from the WUFI Passive North America database. For materials not found in this database, the general materials database was used. Due to the use of a vented rain screen for the wall assembly, the exterior cladding layer was excluded from thermal modeling.

\subsubsection{Verification of WUFI Passive Model Parameters}

Input parameters used to model the reference building were compared with parameters of the Dublin Passive House WUFI Passive model (PHIUS, 2013a). The Passive House Institute U.S verified input parameters of the Dublin Passive House model during the certification process. Additionally, PHIUS technical bulletins and pre-certification documents were followed during development of the reference building model (PHIUS, 2013c; PHIUS, 2014c). These documents describe the methods for calculating mechanical system and appliance parameters for use with 
WUFI Passive. The documents also list acceptable parameter ranges and default values to be used where no product data is available (PHIUS, 2014c).

\subsection{Building Envelope Greenhouse Gas Model}

The reference building was modeled to determine envelope embodied global warming potential for each location and for three different assembly configurations. This Section describes the software, assumptions and system boundaries used in the analysis.

\subsubsection{Life Cycle Assessment Software}

Athena Impact Estimator (Athena IE) is a whole building, cradle-to-grave, life cycle assessment tool used for evaluation of the environmental impact of various design decisions (Athena, 2014a). The tool is suitable for modeling the life cycle impact of building shell materials and assemblies for all North American building types and allows for distinction of regional impacts, including aspects such as regional electricity grid and product manufacturing impacts, among others (Ibid.). Additionally, Athena (2014a) states that its software can be used to analyze the relative impact of trade-offs between life cycle operating and embodied greenhouse gas emissions for a range of design choices.

\subsubsection{Software Version and Data Sources}

Athena Impact Estimator version 4.5.0102, released in November 2013 and revised in January 2014, was used for this work. The Athena IE software uses a life cycle inventory (LCI) database developed by the Athena Institute that covers a wide array of building materials and products. The database also accounts for regional differences in environmental impact of the materials. The data is obtained from actual manufacturing facilities or engineered process models (Athena, 2014b). 


\subsubsection{Metrics for Assessment}

The metrics used to assess the performance of various envelope assemblies included life cycle embodied carbon equivalent emissions and life cycle operating carbon equivalent emissions. Athena IE outputs data for both embodied GWP and operating GWP in units of $\mathrm{kg} \mathrm{CO}_{2} \mathrm{eq}$, which were subsequently converted to $\mathrm{Mg} \mathrm{CO}_{2}$ eq.

\subsubsection{General Model Assumptions}

Assessment of embodied GWP was limited to envelope materials. Athena IE is currently not capable of assessing the embodied impacts of certain building elements such as building services, appliances, cabinetry and fixtures. However, it does allow for a comparative analysis of the impacts of changing insulation levels or selecting various envelope materials, including cladding and interior surface finishes. A comparative assessment was deemed sufficient for the purposes of this research, since the reason for including embodied emissions was to investigate the interaction between envelope insulation levels and operating GWP. Non-envelope materials such as furnishings, appliances, and fixtures were therefore excluded from the assessment, since they do not have a direct impact on operating GWP and are not specific to the requirements of the Passive House Standard. Although the mechanical systems assessed in this study differ from systems used in standard construction and differences in embodied impact between mechanical system cases are likely, building services were not assessed because Athena currently lacks these capabilities. This was deemed acceptable, since research by Passer et al. (2012) indicates that building services only make up a small proportion of total embodied energy in Passive Houses. Finally, an assembly service life of 60-years was assumed, which is consistent with component service lives assumed in life cycle assessment research by Himpe et al. (2013) and Bowick (2011). 


\subsubsection{System Boundaries}

In order to perform life cycle analysis, a system boundary must be delineated. The system boundary for evaluation of embodied GWP was determined by the capabilities of the software. Athena IE is able to account for the impacts of material manufacture, resource extraction and recycled content, associated transport, on-site building construction, maintenance and replacement of materials, along with demolition and disposal (Athena, 2014a).

\subsection{Reference Building Model}

Reference building assemblies were modeled for each location using Athena IE to determine the impact of each assembly on embodied GWP. Athena IE was also used to model operating GWP for each combination of location and mechanical system case. Evaluation of embodied GWP was conducted to determine the impact of envelope material choice and geographic location. Results of the envelope embodied GWP assessment were compared to operating GWP to identify the significance of envelope embodied GWP. A complete description of the Athena IE reference building modeling procedure, including input parameters is provided in Appendix B, while the following sections summarize the individual methods used to assess embodied GWP, operating GWP and envelope life cycle GWP.

\subsubsection{Impact of Assembly Material Choice on Embodied GWP}

When attempting to design building envelopes with low embodied GWP, it is important to understand the influence that material choices can have on the outcome. An assessment of individual life cycle processes was conducted to determine the dominant contributor to assembly embodied GWP and to identify the underlying reasons for any geographic variations. Additionally, three different envelope material configurations were modeled using Athena IE to determine the range of impact that material choice can have on embodied GWP for each of the three previously defined locations. Configurations 1 and 2 were created to represent insulation materials with low and high-embodied GWP, respectively. A third configuration was created to represent wall cladding material with high-embodied 
GWP for comparison against Configurations 1 and 2 (Table 4-8). Results are reported in Section 5.1 .1 (p. 54).

Table 4-8 Summary of Assembly Insulation Materials Selected for Analysis of Embodied GWP

\begin{tabular}{|l|llll|ll|}
\hline & \multicolumn{4}{|c|}{ Insulation } & \multicolumn{2}{c|}{ Cladding } \\
\cline { 2 - 7 } Configuration ID & GWbodied & Wall & Roof & Slab & Embodied & Wall \\
Configuration 1 & Low & Material & Material & Material & GWP & Material \\
Configuration 2 & High & Fiberglass & Fiberglass & XPS & Low & Pine \\
Configuration 3 & High & Flberglass & Fiberglass & XPS & High & Metal \\
\hline
\end{tabular}

For Configuration 1, blown-in cellulose insulation was specified as the low embodied GWP material used in the walls and roof assemblies. EPS was the lowest embodied GWP material available which was suitable for installation underneath the floor slab.

For Configuration 2, blown-in fiberglass insulation was selected for wall and roof assemblies to represent the high-embodied GWP insulation case. An analysis by Harvey (2007) indicated that fiberglass and mineral wool insulation have a similar range of embodied energy, which is directly correlated with embodied GWP. However, a comparison of embodied GWP for these insulation materials using Athena IE, indicated that fiberglass insulation would result in a $20 \%$ higher embodied GWP than mineral wool per $\mathrm{m}^{3}$. Extruded polystyrene (XPS) insulation was selected to represent the high-embodied GWP scenario for the slab assembly had a 48\% higher embodied GWP than EPS per $\mathrm{m}^{3}$. Polyurethane and polyisocyanurate foam insulation materials were identified as having high embodied GWP but were ultimately not considered suitable due to the stance taken by PHIUS that the high embodied GWP of this type of insulation and the quantities required to meet the Standard render this material unfavourable (PHIUS, 2012).

Different envelope insulation configurations were modeled in Athena IE by directly substituting the different materials into the respective assemblies. For wall and roof insulation materials, the range of thermal conductivity values for blown-in fiberglass $(0.038$ to $0.039 \mathrm{~W} / \mathrm{m}-\mathrm{K})$ is somewhat lower than that of blown-in 
cellulose (0.042 to $0.049 \mathrm{~W} / \mathrm{m}-\mathrm{K}$ ) (ASHRAE, 2009). The low end of cellulose conductivity range was assumed for cellulose insulation, representing a wellexecuted dense-packed installation. This allowed for direct substitution and comparison of wall and roof insulation types without the need for re-sizing insulation cavities. A similar situation occurs with slab assembly insulation types, where XPS ( 0.22 to $0.30 \mathrm{~W} / \mathrm{m}-\mathrm{K}$ ) has a lower range of thermal conductivity than EPS ( 0.32 to $0.39 \mathrm{~W} / \mathrm{m}-\mathrm{K})$ (Ibid.). High density EPS suitable for insulating slab assemblies has a thermal conductivity in the lower end of this range. Additionally, Harvey (2007) identified that off gassing of blowing agents in XPS increases the thermal conductivity of the insulation over the service life of the building. Therefore, EPS and XPS were assumed to have equivalent thermal resistances, allowing for the same insulation thicknesses to be compared in the analysis.

Configuration 2 was selected to represent the low embodied GWP cladding case, while Configuration 3 was created for the high-embodied GWP cladding case. Insulation material type was held constant between Configurations 2 and 3 to isolate the impact of changing the wall cladding material. Cladding options were selected by substituting various materials suitable for residential construction from the Athena IE database into the reference building wall assembly. Using this material substitution method, pine ship-lapped and residential grade 30 -gauge metal siding were found to have the lowest and highest embodied GWP, respectively

Locations were specified in Athena IE to determine regional impacts resulting from life cycle stages such as transportation and product manufacturing. Edmonton was the only location of the three not listed in the Athena IE database. Therefore, Calgary, the next closest city in the province was selected as the proxy location as per the method outlined in the Athena IE user guide (Athena, 2014a). Since Athena IE uses aggregated regional data for energy supply carbon intensity and material flows, the impact of choosing a proxy location that was so close to the study location was deemed to yield negligible impacts on the results. 


\subsubsection{Analysis of Reference Building Operating Energy Consumption and Operating GWP}

Reference building operating energy consumption was assessed to determine the impact of climate on energy consumption, while operating GWP was analyzed to determine the impact of mechanical system selection. Results are presented and discussed in Section 5.1 .2 (p. 62).

Operating energy consumption data for each reference building location and mechanical system case was obtained directly from the reported values in WUFI Passive and are representative of energy consumed on-site. A decision was made to evaluate site energy demand, rather than the primary energy demand results reported by WUFI Passive, since a single primary energy factor for electricity is applied to all locations across North America, which is not representative of actual regional differences in losses associated with generation and distribution. Since all factors other than location were kept the same, results are indicative of the impact that the local climate has on energy consumption.

Annual site energy consumption data was generated for each reference building location and mechanical system case using WUFI Passive. This data was subsequently used as input parameters for Athena IE to determine operating GWP. For Case A (NG), natural gas was used to supply heating and domestic hot water, while electricity was used to provide cooling and to power auxiliary equipment such as ventilation, lighting and appliances. Athena IE accepts annual electricity consumption data in units of $\mathrm{kWh}$, while natural gas consumption can be input as either $\mathrm{kWh}$ or $\mathrm{m}^{3}$. WUFI Passive annual energy consumption results are broken out into separate values for space heating, domestic hot water, and auxiliary equipment. Results for auxiliary equipment energy consumption are reported in terms of annual site electricity consumption (kWh/yr), which can be directly input into Athena IE. However, heating and domestic hot water consumption results are reported in units of annual primary energy consumption (kWh/yr), requiring the results to be divided by the primary energy factor for natural gas $\left(\mathrm{PEF}_{\mathrm{NG}}=1.1\right)$ to obtain annual site energy consumption values (PHIUS 2014c). 
For Case B (Electric), all of the building energy requirements are met by electricity. Therefore, total primary energy demand results were used to backcalculate the site electricity consumption values for input into Athena IE. WUFI Passive reports primary energy demand in terms of a treated floor area (TFA) intensity value ( $\mathrm{kWh} / \mathrm{m}^{2}$-yr), which must be converted to a non-intensity based site electricity consumption value ( $\mathrm{kWh} / \mathrm{yr})$. This was accomplished by multiplying the primary energy demand intensity value by the reference building treated floor area $\left(\mathrm{TFA}=119 \mathrm{~m}^{2}\right)$ and dividing the result by the Passive House primary energy factor for electricity, $\mathrm{PEF}_{\mathrm{ELEC}}=2.7$ (PHIUS, 2014c).

Life cycle operating GWP determined for each location and mechanical system case represent the combined impact of energy consumed by space conditioning and auxiliary equipment over a 60-year building life span. Results were then compared to determine which mechanical system offered the best operating GWP performance in each location.

\subsubsection{Comparison of Envelope Embodied GWP and Operating GWP}

A comparison of reference building envelope embodied GWP and operating GWP was made in order to understand the significance of envelope embodied GWP in each location. Results of the investigation are discussed in Section 5.1 .2 (p. 62).

Each of the three previously defined envelope assembly configurations were assessed to define the range of impact that the tested building envelopes have relative to operating GWP for each permutation of location and mechanical system. The impact that envelope embodied GWP has on life cycle GWP was determined by calculating the percent change in emissions with respect to operating emissions (Equation 4-1).

$$
\text { Impact on } L C G W P(\%)=\frac{(\text { Total Emb GWP-Op GWP })}{\text { op GWP }} \times 100
$$

Where: 
Total Emb GWP = sum of embodied global warming potentials of the roof, wall, and slab assemblies ( $\left.\mathrm{Mg} \mathrm{CO}_{2} \mathrm{eq}\right)$

Op GWP = 60-year operating greenhouse gas emissions $\left(\mathrm{Mg} \mathrm{CO}_{2} \mathrm{eq}\right)$

Values representing the total embodied GWP for each assembly configuration were obtained from the results of the previous investigation described in Section 4.5.1 (p. 34). Results from the previous analysis in Section 4.5 .2 (p. 37) were used as input values for operating GWP.

\subsubsection{Comparison of Passive House Standard and Regional Based Methods for Calculating Operating GWP}

Currently, the Passive House Standard calculation method for determining operating GWP uses a single electricity grid carbon emission factor for all of North America. Use of operating GWP calculated from the Passive House Standard method could lead designers to select mechanical systems or other equipment that may result in higher operating GWP than is anticipated. This analysis was limited to looking at electricity emission factors and does not consider the implications of applying continent-wide emission factors for other energy carriers such as natural gas. Results of this investigation are reported in Section 5.1 .3 (p. 70).

Locations assessed for this study coincide with each of Canada's three interconnection regions, with Toronto, Montreal and Edmonton representing Eastern, Quebec, and Western electricity grids, respectively (Figure 4-9). Canadian provinces primarily trade electricity with American states to the south, as opposed to neighbouring provinces to the east and west (Bordeleau, 2011). Additionally, the amount of electricity imported to the locations analyzed in this study is insignificant compared to the total electricity generated within the respective provinces, as indicated in Table 4-9.

To understand the impact that the Passive House Standard calculation method can have on design decisions, a comparison was made between operating GWP results calculated based on continental (Passive House method) and regional 
(Athena IE method) carbon intensities. Results were obtained for the Passive House Standard method by modeling reference building operating GWP for each combination of location and mechanical system using WUFI Passive.

Several calculation steps were required to determine the operating GWP from WUFI Passive, since the reports generated only indicate results for mechanical system operating GWP. Therefore, emissions generated by the building auxiliary equipment had to be calculated for each permutation of location and mechanical system. WUFI Passive reports include the annual primary energy demand of auxiliary equipment, which when multiplied together with a carbon emission factor can be used to calculate operating GWP. 


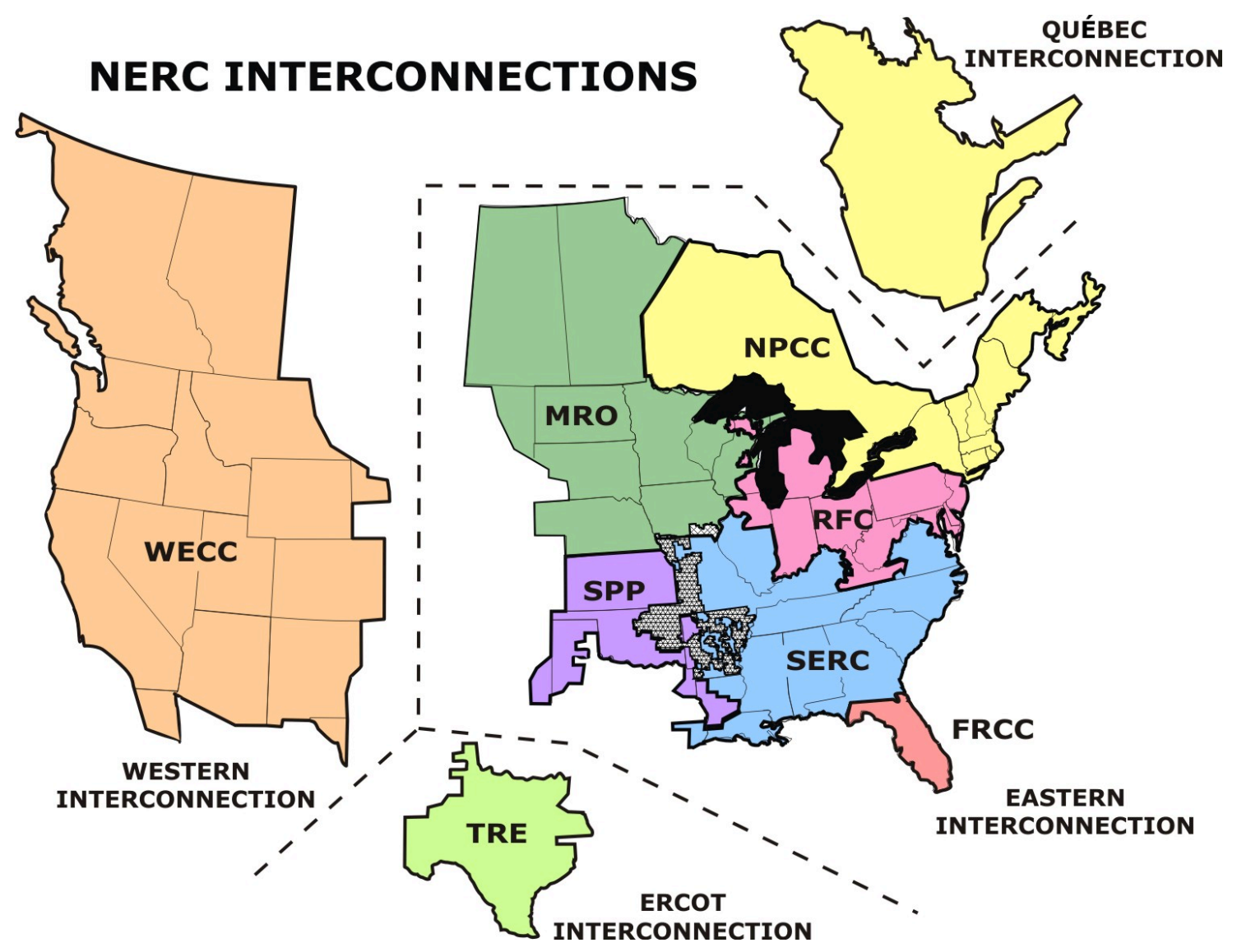

Figure 4-9 North American Grid Interconnections, adapted from NERC (2013)

Table 4-9 Provincial Electricity Production, Export and Import Data

\begin{tabular}{|c|c|c|c|}
\hline Province & $\begin{array}{l}\text { Total Production } \\
\text { (GWh) }\end{array}$ & $\begin{array}{l}\text { Exports } \\
\text { (GWh) }\end{array}$ & $\begin{array}{l}\text { Imports } \\
\text { (GWh) }\end{array}$ \\
\hline Ontario $^{a}$ & $154,350.5$ & $13,823.3$ & 655.1 \\
\hline Quebec $^{b}$ & $198,918.2$ & $24,037.8$ & 83.4 \\
\hline Alberta $^{c}$ & $66,111.6$ & 41.6 & 851.8 \\
\hline \multicolumn{4}{|l|}{ Notes: } \\
\hline \multicolumn{4}{|c|}{ a Data obtained from Statistics Canada (2014a) } \\
\hline \multicolumn{4}{|c|}{${ }^{b}$ Data obtained from Statistics Canada (2014b) } \\
\hline \multicolumn{4}{|c|}{ c Data obtained from Statistics Canada (2014c) } \\
\hline
\end{tabular}

The electricity grid carbon emission factor assumed by the Passive House Standard for all of North America is $680 \mathrm{~g} \mathrm{CO}_{2} \mathrm{eq} / \mathrm{kWh}_{\text {final }}$ (Feist, 2007). This value represents the quantity of carbon dioxide equivalent GWP per kWh of energy used on site. Total operating emissions were calculated using the Passive House method 
by first adding together ventilation system $\left(Q_{\text {vent }}\right)$ and appliance $\left(Q_{\text {app }}\right)$ electricity demand results from WUFI Passive to obtain the auxiliary equipment electricity demand $\left(Q_{\text {aux }}\right)$ (Equation 4-2).

$$
\mathbf{Q}_{\text {aux }}=\mathbf{Q}_{\text {vent }}+\mathbf{Q}_{\text {app }}
$$

Auxiliary electricity demand values were subsequently multiplied by the electricity carbon emission factor $\left(\mathrm{x}_{\mathrm{CO}}\right)$ to obtain the auxiliary equipment annual operating GWP (Op GWP aux) (Equation 4-3).

$$
\text { Op GWP }_{\text {aux }}=\mathbf{Q}_{\text {aux }} \cdot \mathbf{x}_{\text {co2 }}
$$

Auxiliary equipment annual GWP was then added to the mechanical system annual GWP (Op GWP mech) obtained from WUFI Passive. The resulting values were multiplied by the operating life span of the building (60 years) to yield the final operating GWP (Op GWP final) (Equation 4-4).

$$
0 p \mathrm{GWP}_{\text {final }}=0 p \mathrm{GWP} \text { aux }+0 p \mathrm{GWP}_{\text {mech }}
$$

Results previously obtained from the method described in Section 4.5 .2 (p. 38) were used to represent the Athena IE calculation method for comparison with the Passive House method. The percent difference between the two methods was calculated to evaluate the amount of divergence in the respective results.

\subsection{Envelope Parametric Analysis}

\subsubsection{Impact of Insulation Thickness on Envelope Embodied GWP}

The impact that insulation thickness has on assembly embodied GWP was evaluated for three locations and three assembly material configurations representing different insulation and wall cladding material types. Results are presented in Section 5.2.1 (p. 72). The three assembly material configurations evaluated were 
previously defined in Section 4.5.1 (p. 34). Each assembly was evaluated in isolation by varying the thickness of insulation using Athena IE. Insulation increments for each assembly are defined as follows.

Wall assemblies were modeled with varying levels of blown in insulation, defined by the depth of the stud wall or I-joist cavity (Table 4-10). The first two iterations were conducted for a $140 \mathrm{~mm}(2 " \mathrm{x} 6$ ") structural stud cavity, Iteration 0 contained no insulation (air filled cavity) and Iteration 1 was filled with blown in cellulose insulation. Iterations 2 and 3 consisted of double stud wall systems, where an insulation cavity wall was added to the exterior with dimensions of $89 \mathrm{~mm}$ and $140 \mathrm{~mm}$ for Iterations 2 and 3, respectively. Iterations 4 through 11 comprised a $140 \mathrm{~mm}$ interior structural stud cavity and an exterior insulation cavity framed with I-joists. The thickness of the I-joist wall was increased for each iteration by moving to the next size available from the I-joist manufacturer to increase the insulation cavity depth.

Table 4-10 Wall Assembly Iteration Insulation Levels

\begin{tabular}{|c|c|c|c|c|}
\hline Iteration Number & $\begin{array}{l}\begin{array}{l}\text { Stud Cavity } \\
\text { Insulation Depth } \\
(\mathrm{mm})\end{array} \\
\end{array}$ & $\begin{array}{l}\text { Double Stud Cavity } \\
\text { Insulation Depth } \\
(\mathrm{mm})\end{array}$ & $\begin{array}{l}\text {-joist Insulation } \\
\text { Depth } \\
(\mathrm{mm})\end{array}$ & $\begin{array}{l}\text { Total Insulation } \\
\text { Depth } \\
(\mathrm{mm})\end{array}$ \\
\hline Reference Building Wall & 140 & 0 & 25 & 394 \\
\hline 0 & 0 & 0 & & 0 \\
\hline 1 & 140 & 0 & & 140 \\
\hline 2 & 140 & 89 & & 229 \\
\hline 3 & 140 & 140 & & 280 \\
\hline 4 & 140 & 0 & 24 & 381 \\
\hline 5 & 140 & 0 & 30 & 442 \\
\hline 6 & 140 & 0 & 35 & 496 \\
\hline 7 & 140 & 0 & 40 & 546 \\
\hline 8 & 140 & 0 & 45 & 597 \\
\hline 9 & 140 & 0 & 50 & 648 \\
\hline
\end{tabular}

The roof assembly model was created based on the reference building. Depths of insulation for Iterations 0 through 2 were adjusted according to the depth of the interior ceiling service cavity (Table 4-11). For Iterations 0 to 1 , the service cavity was constructed from $38 \mathrm{~mm}$ x $89 \mathrm{~mm}(2 " \mathrm{x} 4$ ") joists spaced at $400 \mathrm{~mm}$ (16 
inches) on centre. For Iterations 2 through 9, the ceiling service cavity was increased to $140 \mathrm{~mm}$ by using $38 \mathrm{~mm}$ x $140 \mathrm{~mm}$ (2"x6") joists, $400 \mathrm{~mm}$ on centre. For insulation Iterations 3 through 10, additional insulation was added on top of the ceiling assembly in the vented attic space (between the roof trusses) and increased by $100 \mathrm{~mm}$ increments for each of the subsequent iterations.

Table 4-11 Roof Assembly Iteration Insulation Levels

\begin{tabular}{|r|rrrr|}
\hline Iteration Number & $\begin{array}{l}\text { Service Cavity } \\
\text { Insulation Depth } \\
(\mathrm{mm})\end{array}$ & $\begin{array}{l}\text { Attic Insulation Depth } \\
(\mathrm{mm})\end{array}$ & $\begin{array}{l}\text { Total Insulation } \\
\text { Depth } \\
(\mathrm{mm})\end{array}$ \\
\hline Reference Building Roof & 140 & 500 & 640 \\
0 & 0 & 0 & 0 \\
1 & 89 & 0 & 89 \\
2 & 140 & 0 & 140 \\
3 & 140 & 100 & 240 \\
4 & 140 & 200 & 340 \\
5 & 140 & 300 & 440 \\
6 & 140 & 400 & 540 \\
7 & 140 & 500 & 640 \\
8 & 140 & 600 & 740 \\
9 & 140 & 700 & 840 \\
10 & 140 & 800 & 940 \\
\hline
\end{tabular}

The floor slab assembly consisted of a $200 \mathrm{~mm}$ (8-inch) concrete floor slab placed on top of a polyethylene vapour retarder, with varying levels of EPS insulation located underneath these two layers. EPS insulation depths for Iterations 0 through 4 were increased from $0 \mathrm{~mm}$ to $102 \mathrm{~mm}$ (level 0 to 4 ) in $25.4 \mathrm{~mm}$ ( $1 \mathrm{inch}$ ) increments (Table 4-12). For Iterations 5 through 10, the insulation depth was increased in $50.8 \mathrm{~mm}$ ( 2 inch) increments to a maximum of $406 \mathrm{~mm}$ (16 inches). This was done in order to account for the effects of diminishing energy savings when modeling life cycle GWP. These increments reflect commonly available thicknesses of EPS insulation. 
Table 4-12 Slab Assembly Iteration Insulation Levels

\begin{tabular}{|l|l|}
\hline & \\
Iteration Number & $\begin{array}{l}\text { Underslab } \\
\text { Insulation Depth } \\
(\mathrm{mm})\end{array}$ \\
\hline Reference Building Slab & 254 \\
0 & 0 \\
1 & 25 \\
2 & 51 \\
3 & 76 \\
4 & 102 \\
5 & 152 \\
6 & 203 \\
7 & 254 \\
8 & 305 \\
9 & 356 \\
10 & 406 \\
\hline
\end{tabular}

Table 4-13 provides a summary of all assembly insulation levels selected. Material take-offs were generated for each of the assembly iterations is included in Appendix B, while assembly sections generated using WUFI Passive are presented in Appendix C. Each assembly insulation level was modeled for each location by inputting the material take-off data into Athena IE. 
Table 4-13 Summary of Iteration Assembly Insulation Levels

\begin{tabular}{|c|c|c|c|}
\hline $\begin{array}{l}\text { Insulation } \\
\text { Level }\end{array}$ & $\begin{array}{l}\text { Wall } \\
\text { Insulation } \\
\text { Thickness } \\
(\mathrm{mm})\end{array}$ & $\begin{array}{l}\text { Roof } \\
\text { Insulation } \\
\text { Thickness } \\
(\mathrm{mm})\end{array}$ & \begin{tabular}{|l} 
Slab \\
Insulation \\
Thickness \\
$(\mathrm{mm})$
\end{tabular} \\
\hline 0 & 0 & 0 & 0 \\
\hline 1 & 140 & 89 & 25 \\
\hline 2 & 229 & 140 & 51 \\
\hline 3 & 280 & 240 & 76 \\
\hline 4 & 381 & 340 & 102 \\
\hline 5 & 442 & 440 & 152 \\
\hline 6 & 496 & 540 & 203 \\
\hline 7 & 546 & 640 & 254 \\
\hline 8 & 597 & 740 & 305 \\
\hline 9 & 648 & 840 & 356 \\
\hline 10 & - & 940 & 406 \\
\hline Reference & 394 & 640 & 254 \\
\hline
\end{tabular}

\subsubsection{Relative Impact of Insulation Thickness on Building Life Cycle GWP}

The impact of insulation thickness on both operating GWP and embodied GWP were evaluated. Since operating GWP is partially dependent on the type of fuel consumed to provide space conditioning, two mechanical systems representing two commonly available fuel types were assessed. Although operating GWP at each location differs between Case A (NG) and Case B (Electric) mechanical systems, the envelope embodied GWP for Cases A and B remain identical.

In order to evaluate the impact of insulation thickness on assembly life cycle GWP for each location and mechanical system, the magnitude of the combined reduction in embodied GWP and operating GWP was determined for each incremental increase in insulation thickness. The impact of each insulation increment was evaluated relative to the reference building envelope, with results reported in Section 5.2 .2 (p. 81). This test was developed to determine whether further additions of insulation beyond reference building levels yield a net reduction in life cycle GWP. 
WUFI Passive modeling was conducted by varying the insulation thickness of one assembly while holding the other two assemblies constant at reference building insulation levels to isolate the impact of the assembly in question. Assembly insulation thickness was adjusted from $0 \mathrm{~mm}$ to a maximum value for each type of assembly, as previously defined in Section 4.6 .1 (p. 42). Operating GWP for each increment in assembly insulation thickness was determined using the method described in Section 4.5 .2 (p. 37), while assembly embodied GWP results were obtained from the previous analysis described in Section 4.6.1 (p. 42). These modeling runs are herein referred to as "assembly iterations".

By comparing assembly iterations to the reference building results, the difference in magnitude of life cycle GWP impact between assembly insulation levels can be determined and data trends can be identified. The GWP impact of the assembly relative to the reference building was calculated by determining both the difference in operating GWP, $\Delta(\boldsymbol{O} \boldsymbol{p} \boldsymbol{G W} \boldsymbol{P})_{\boldsymbol{n}-\boldsymbol{r}}$ and embodied GWP, $\Delta(\boldsymbol{E} \boldsymbol{m} \boldsymbol{b} \boldsymbol{G W} \boldsymbol{P})_{\boldsymbol{n}-\boldsymbol{r}}$ between the assembly in question and reference building using Equations 4-5 and $4-6$, respectively.

$$
\Delta(\boldsymbol{O p} G W P)_{n-r}=(\mathrm{Op} G W P)_{n}-(\mathrm{Op} G W P)_{r}
$$

And

$$
\Delta(E m b G W P)_{n-r}=(E m b G W P)_{n}-(E m b G W P)_{r}
$$

Where:

$(\boldsymbol{O} \boldsymbol{p} \boldsymbol{G W P})_{\boldsymbol{n}}=$ Operating GWP for assembly iteration $\boldsymbol{n}\left(\mathrm{Mg} \mathrm{CO}_{2} \mathrm{eq}\right)$ $(\boldsymbol{O} \boldsymbol{p} \boldsymbol{G W P})_{\boldsymbol{r}}=$ Operating GWP for reference building assembly $\left(\mathrm{Mg} \mathrm{CO}_{2} \mathrm{eq}\right)$ $(\boldsymbol{E m b} \boldsymbol{G W P})_{n}=$ Embodied GWP for assembly iteration $\boldsymbol{n}\left(\mathrm{Mg} \mathrm{CO}_{2} \mathrm{eq}\right)$ $(\boldsymbol{E} \boldsymbol{m} \boldsymbol{b} \boldsymbol{G W P})_{r}=$ Embodied GWP for reference building assembly $\left(\mathrm{Mg} \mathrm{CO}_{2} \mathrm{eq}\right)$

Operating and embodied difference values were then added together to determine the relative impact that changing to the assembly configuration in question has on the life cycle GWP (Equation 4-7). This single metric is referred to 
as the relative life cycle global warming potential, $(\text { Relative } \mathbf{L C} \boldsymbol{G W P})_{n-r}$ and is measured in units of $\mathrm{Mg} \mathrm{CO}_{2}$ eq.

$(\text { Relative LC GWP })_{n-r}=\Delta(\text { Emb GWP })_{n-r}+\Delta(O p G W P)_{n-r}$

Assembly iterations with positive values for relative LC GWP indicate an increase in GWP impact over the reference building assembly, whereas negative values represent a decrease.

\subsection{Envelope Life Cycle Optimization Model}

\subsubsection{Selection of Envelope Scenarios Based on Life Cycle GWP}

Whole house scenarios were modeled for each climate and mechanical system case for later comparison against respective scenarios meeting the annual heating demand criteria of the Passive House Standard. The dataset of life cycle GWP for individual building assemblies was used to create several whole house scenarios for evaluation of the relationship between annual heating demand and life cycle greenhouse gas emissions. These scenarios were based on the reference building, with different combinations of opaque assemblies including walls, roof and floor slab. Embodied GWP of these envelope components, along with operating GWP were included in the evaluation of envelope life cycle GWP performance.

Scenarios were selected based on the calculation of a life cycle GWP reduction indicator. This indicator was created to standardize results of the individual building assembly analyses for comparison of the assemblies, since the previously modeled assembly iterations had differing increments in insulation thickness. By dividing the difference in assembly life cycle GWP by the difference in insulation thickness, the magnitude of GWP reductions achieved by increasing the insulation thickness could be determined. Results are presented in Section 5.3 (p. 92).

A threshold value criterion representing a tolerable level of diminishing GWP reductions with increasing insulation thickness was estimated based on the 
diminishing return curves from the results in Section 5.3 (p. 92). A set threshold value criterion was necessary to standardize the selection of assemblies to create whole building envelope scenarios for further analysis. The threshold value criterion used for scenario selection was:

\section{LC GWP = $-50 \mathrm{~kg} \mathrm{CO} 2 \mathrm{eq} / \mathrm{mm}$ insulation}

This value represents a first guess at a "reasonable limit", beyond which the magnitude of life cycle GWP reductions achieved no longer justify the added insulation. Additional scenarios for assembly insulation levels just above and below the indicator target value were included to increase confidence in the analysis and to extend the data set for later analysis of the relationship between annual heating demand and life cycle global warming potential. In the case where this threshold value was not met, an alternative criterion was created which allows for selection of an assembly if the LC GWP result is the same for two consecutive insulation increments. This alternative criterion allows for a situation where a plateau between results occurs.

\subsubsection{Selection of Passive House Envelope Scenarios Optimized for Life Cycle GWP} Assemblies were selected for each location and mechanical system configuration to form whole building envelope scenarios that meet the Passive House Standard annual heating demand criteria of $15 \mathrm{kWh} / \mathrm{m}^{2}$-yr. Wall, roof and slab assemblies selected for each scenario represent combinations with the lowest life cycle GWP that also met the AHD criteria. Selection was accomplished through the use of a brute-force optimization method, also known as direct search. This optimization method was very simple but was limited in that it was slow and could only optimize one variable at a time (Bolker, 2008). Other optimization methods and programs were considered, such as Pareto-based optimization using a multi-objective genetic algorithm (Flager et al., 2012) and COPRAS, a multiple criteria complex proportional assessment method (Lapinskiene \& Martinaitis, 2013). These methods were ultimately rejected due to the requirement of specialized software and their inherent complexity. Brute-force optimization offered a simple method without the 
need for any specialized software and was capable of being used for selecting envelope assembly configurations that will meet the Passive House Standard annual heating demand criteria with low life cycle GWP.

The brute-force method was applied as summarized in the following process description and in Figure 4-10, with numbers in the Figure correspond to the listed steps. For each location and mechanical system case:

1. All assembly LC GWP results were arranged into a single spreadsheet column with assembly iteration names in adjacent column

2. The difference in GWP (reduction) was calculated between each insulation level for each assembly type in the column adjacent to the results

3. All columns were then sorted from highest to lowest reduction value

4. A wall, roof, and slab assembly were selected from the top of list as the evaluation starting point. These assemblies were input into WUFI Passive to check whether AHD met the target value of $15 \mathrm{kWh} / \mathrm{m}^{2}$-yr $\left(+/-0.5 \mathrm{kWh} / \mathrm{m}^{2-}\right.$ yr)

5. If the AHD target value was not met, the next sequential assembly in the column was selected, while respecting the order of assembly number (e.g. the next step beyond TO Walls 6 was to change the roof assembly to TO Roof 6 . Despite the fact that TO Walls 8 had a greater GWP reduction value, it was skipped and TO Walls 7 was assessed. This was required to maintain the sequence of assembly insulation level increases.

6. At this point, the Passive House AHD criteria was met for this permutation of location and mechanical system case 


\begin{tabular}{|c|c|c|c|c|c|c|}
\hline $\begin{array}{c}1 . \\
\text { Assembly }\end{array}$ & GWP & $\begin{array}{c}2 . \\
\text { Reduction }\end{array}$ & & & & \\
\hline TO Walls 0 & 531.8 & & & & & \\
\hline TO Walls 1 & 156.4 & 375.5 & & & & 3. \\
\hline TO Walls 2 & 127.6 & 28.8 & & Assembly & GWP & Reduction \\
\hline TO Walls 3 & 122.6 & 5.0 & & TO Walls 1 & 156.4 & 375.5 \\
\hline TO Walls 4 & 110.3 & 12.2 & & TO Roof 1 & 154.6 & 152.9 \\
\hline TO Walls 5 & 107.1 & 3.3 & & TO Slab 1 & 152.5 & 31.1 \\
\hline TO Walls 6 & 104.4 & 2.6 & & TO Walls 2 & 127.6 & 28.8 \\
\hline TO Walls 7 & 103.0 & 1.4 & & TO Roof 2 & 139.5 & 15.1 \\
\hline TO Walls 8 & 101.6 & 1.4 & & TO Roof 3 & 125.8 & 13.7 \\
\hline TO Walls 9 & 100.2 & 1.4 & & TO Walls 4 & 110.3 & 12.2 \\
\hline TO Roof 0 & 307.6 & & & TO Slab 2 & 140.6 & 11.9 \\
\hline TO Roof 1 & 154.6 & 152.9 & & TO Slab 3 & 134.1 & 6.5 \\
\hline TO Roof 2 & 139.5 & 15.1 & & TO Walls 3 & 122.6 & 5.0 \\
\hline TO Roof 3 & 125.8 & 13.7 & & TO Roof 4 & 121.0 & 4.8 \\
\hline TO Roof 4 & 121.0 & 4.8 & & TO Slab 5 & 126.2 & 4.5 \\
\hline TO Roof 5 & 118.1 & 2.9 & & TO Slab 4 & 130.7 & 3.5 \\
\hline TO Roof 6 & 116.3 & 1.7 & & TO Walls 5 & 107.1 & 3.3 \\
\hline TO Roof 7 & 115.8 & 0.5 & & TO Roof 5 & 118.1 & 2.9 \\
\hline TO Roof 8 & 114.6 & 1.1 & & TO Slab 6 & 123.4 & 2.7 \\
\hline TO Roof 9 & 114.1 & 0.5 & & TO Walls 6 & 104.4 & 2.6 \\
\hline TO Roof 10 & 113.5 & 0.5 & & TO Roof 6 & 116.3 & 1.7 \\
\hline TO Slab 0 & 183.5 & & & TO Walls 8 & 101.6 & 1.4 \\
\hline TO Slab 1 & 152.5 & 31.1 & 6. & TO Walls 7 & 103.0 & 1.4 \\
\hline TO Slab 2 & 140.6 & 11.9 & & TO Walls 9 & 100.2 & 1.4 \\
\hline TO Slab 3 & 134.1 & 6.5 & & TO Roof 8 & 114.6 & 1.1 \\
\hline TO Slab 4 & 130.7 & 3.5 & & TO Slab 9 & 120.6 & 0.9 \\
\hline TO Slab 5 & 126.2 & 4.5 & & TO Slab 8 & 121.6 & 0.9 \\
\hline TO Slab 6 & 123.4 & 2.7 & & TO Slab 7 & 122.5 & 0.9 \\
\hline TO Slab 7 & 122.5 & 0.9 & & TO Roof 9 & 114.1 & 0.5 \\
\hline TO Slab 8 & 121.6 & 0.9 & & TO Roof 7 & 115.8 & 0.5 \\
\hline TO Slab 9 & 120.6 & 0.9 & & TO Roof 10 & 113.5 & 0.5 \\
\hline TO Slab 10 & 120.3 & 0.3 & & TO Slab 10 & 120.3 & 0.3 \\
\hline
\end{tabular}

Figure 4-10 Brute-force method for selecting Passive House assemblies with lowest life cycle GWP

A summary of the envelope assembly configurations selected for each Passive House scenario is presented in Table 4-14. These scenarios were selected for further modeling in Section 4.7 .3 (p. 52). 
Table 4-14 Summary of Selected Assemblies for Case A (NG) and Case B (Electric) Passive House Scenarios

\begin{tabular}{|l|lll|lcr|}
\hline \multirow{2}{*}{$\begin{array}{c}\text { Scenario } \\
\text { Name }\end{array}$} & \multicolumn{2}{|c|}{ Selected Assembly Insulation Level } & \multicolumn{3}{c|}{ Assembly Insulation Dimensions (mm) } \\
\cline { 2 - 7 } & Roof & Walls & Slab & Roof & Walls & Slab \\
\hline TO PH A & TO Roof 6 & TO Walls 7 & TO Slab 6 & 540 & 546 & 203 \\
TO PH B & TO Roof 5 & TO Wall 8 & TO Slab 6 & 440 & 597 & 203 \\
MTL PH A & MTL Roof 6 & MTL Wall 7 & MTL Slab 7 & 540 & 546 & 254 \\
MTL PH B & MTL Roof 10 & MTL Wall 9 & MTL Slab 5 & 940 & 648 & 152 \\
EDM PH A & EDM Roof 8 & EDM Walls 9 & EDM Slab 10 & 740 & 648 & 406 \\
EDM PH B & EDM Roof 9 & EDM Wall 9 & EDM Slab 9 & 840 & 648 & 356 \\
\hline
\end{tabular}

\subsubsection{Comparison of Envelope Scenario Annual Heat Demand and Life Cycle GWP}

A comparison of scenario annual heat demand and life cycle GWP was performed to determine if a relationship exists between the two variables. Additionally, the comparison was used to determine whether the Passive House criteria for annual heat demand results in similar GWP reductions for all locations evaluated. Results are discussed in Section 5.3 .2 (p. 99).

Annual heat demand and life cycle global warming potential were modeled for a total of 31 envelope scenarios. This included 6 reference building scenarios defined in Section 4.2 .5 (p. 18), 19 envelope scenarios optimized for life cycle GWP, as defined in Section 4.7.1 (p. 48) and the 6 Passive House envelope scenarios described in Section 4.7.2 (p. 49). A summary of scenarios evaluated is presented in Table 4-15. 
Table 4-15 Summary of Scenarios Evaluated

\begin{tabular}{|l|l|}
\hline Case A Scenario Names & Case B Scenario Names \\
\hline Toronto & Toronto \\
TO Reference A & TO Reference B \\
TO Scenario 1A & TO Scenario 1B \\
TO Scenario 2A & TO Scenario 2B \\
TO Scenario 3A & TO Scenario 3B \\
TO Passive House A & TO Passive House B \\
Montreal & Montreal \\
MTL Reference A & MTL Reference B \\
MTL Scenario 1A & MTL Scenario 1B \\
MTL Scenario 2A & MTL Scenario 2B \\
MTL Scenario 3A & MTL Scenario 3B \\
\hline - & MTL Scenario 4B \\
MTL Passive House A & MTL Passive House B \\
Edmonton & Edmonton \\
EDM Reference A & EDM Reference B \\
EDM Scenario 1A & EDM Scenario 1B \\
EDM Scenario 2A & EDM Scenario 2B \\
EDM Scenario 3A & EDM Scenario 3B \\
EDM Passive House A & EDM Passive House B \\
\hline
\end{tabular}

Annual heat demand values were modeled using WUFI Passive, while life cycle GWP results were determined using Athena IE, according to the method in Section 4.6 .2 (p. 46). Annual heat demand results were then graphed against life cycle GWP for both mechanical system cases, with the scenarios organized by location. The relationship between AHD and life cycle GWP was determined for each location by fitting a linear trend line to the data and examining the slope value of the trendline equation. The slope value allows for the significance that changing AHD has on life cycle GWP to be determined. 


\section{Results and Discussion}

This Section details the results obtained via the methods described in Section 4 (p. 13) and provides an analysis of the results in order to answer the research questions identified in Section 3.2 (p. 9).

\subsection{Results of Reference Building Models}

\subsubsection{Impact of Envelope Material Choice on Embodied GWP}

A life cycle analysis of reference building envelope embodied GWP was conducted to identify the process with the greatest influence and to determine the underlying factors behind geographic variations in embodied GWP results. Additionally, three envelope assembly configurations were tested for each location to determine the impact that various assembly materials had on embodied GWP, according to the method described in Section 4.5 .1 (p. 34).

\section{Influence of Life Cycle Stage on Envelope Embodied GWP}

Results summarized in Table 5-1 indicate that for all locations assessed, the product manufacturing life cycle stage contributes the majority of emitted carbon for the wall assembly. Manufacturing process related emissions vary greatly based on location, with assembly components manufactured for Edmonton 216\% greater than Montreal and 188\% greater than Toronto. The end of life (deconstruction and demolition) stage contributes significantly to reducing the overall assembly embodied GWP through sequestration of carbon with results consistent across all three locations. Athena IE does not include temporary sequestration of carbon during the service life of a material but does provide a credit for the use of wood products harvested from forests where no subsequent land use change occurs. The methodology used by Athena IE for carbon sequestration accounting uses a 100year time-frame and is conducted in overall accordance with three international standards, including: PAS 2050; ISO/TC 14067; and WRI GHG Protocol for Products 
(Athena, 2014a). Additionally, end-of-life emissions associated with wood products are accounted for according to the Product Category Rules for North America developed by FPInnovations. This includes accounting of carbon emissions related to the various end-of-life processes including: recycling; combustion; landfill gas combustion; and fugitive or non-combustion landfill emissions (Ibid.).

Table 5-1 Summary of Reference Building Wall Assembly Embodied GWP

\begin{tabular}{|c|c|c|c|c|}
\hline Life Cycle Stage & Process & $\begin{array}{l}\text { Toronto } \\
\left(\mathrm{Mg} \mathrm{CO}_{2} \text { eq }\right)\end{array}$ & $\begin{array}{l}\text { Montreal } \\
\left(\mathrm{Mg} \mathrm{CO}_{2} \text { eq) }\right.\end{array}$ & $\begin{array}{l}\text { Edmonton } \\
\left(\mathrm{Mg} \mathrm{CO}_{2} \text { eq }\right)\end{array}$ \\
\hline \multirow{2}{*}{ Product } & Manufacturing & 2.33 & 2.02 & 4.37 \\
\hline & Transportation Emissions & 0.29 & 0.30 & 0.31 \\
\hline \multirow{2}{*}{ Construction Process } & Contruction-Installation & 0.35 & 0.25 & 0.69 \\
\hline & Transportation Emissions & 0.48 & 0.48 & 0.38 \\
\hline \multirow{2}{*}{ Use } & Replacement Manufacturing & 0.58 & 0.39 & 1.10 \\
\hline & Transportation Emissions & 0.14 & 0.15 & 0.15 \\
\hline \multirow{2}{*}{ End Of Life } & De-construction \& Demolition & -11.00 & -11.00 & -11.00 \\
\hline & Transportation Emissions & 0.09 & 0.09 & 0.09 \\
\hline \multirow{2}{*}{ Total } & Non-Transport Emissions & -7.71 & -8.32 & -4.82 \\
\hline & Transport Emissions & 0.99 & 1.02 & 0.93 \\
\hline
\end{tabular}

For the reference building roof assembly, a majority of the impacts are incurred during the product manufacturing life cycle stage, while the end of life stage reduces the overall embodied GWP of the assembly (Table 5-2). The negative values in the end of life stage are a result of the roof assembly being comprised primarily of wood products. The amount of emissions incurred depends largely on where the product was manufactured. Roof assembly materials manufactured in Edmonton incur significantly higher impacts than Montreal or Toronto. Although the roof structure and insulation consisted of wood based materials, the end of life embodied GWP was substantially higher than that of the wall structure. This difference can be explained by the use of standing seam metal roofing, which does not sequester carbon but rather increases the GWP burden of the assembly. The wall assembly yielded a lower end of life GWP than for the roof assembly since wall cladding was comprised of carbon sequestering pine board. It should be recognized 
that these results represent approximations, since Athena IE assumes materials currently sent for recycling or landfilling will continue to follow these end-of-life pathways in the future. Furthermore, landfilled materials are assigned additional approximated carbon emissions due to transportation to and decomposition of the materials in the landfill (Ibid.).

Table 5-2 Summary of Reference Building Roof Assembly Embodied GWP

\begin{tabular}{|ll|rrr|}
\hline \multirow{2}{*}{ Life Cycle Stage } & Process & $\begin{array}{l}\text { Toronto } \\
\left(\mathrm{Mg} \mathrm{CO}_{2} \text { eq }\right)\end{array}$ & $\begin{array}{c}\text { Montreal } \\
\left(\mathrm{Mg} \mathrm{CO}_{2} \text { eq }\right)\end{array}$ & $\begin{array}{l}\text { Edmonton } \\
\left(\mathrm{Mg} \mathrm{CO}_{2} \text { eq }\right)\end{array}$ \\
\hline \multirow{2}{*}{ Product } & Manufacturing & 0.79 & 0.73 & $\mathbf{1 . 2 6}$ \\
& Transportation Emissions & 0.10 & 0.11 & $\mathbf{0 . 1 1}$ \\
\hline \multirow{2}{*}{ Construction Process } & Contruction-Installation & 0.09 & 0.07 & $\mathbf{0 . 1 7}$ \\
& Transportation Emissions & $\mathbf{0 . 1 5}$ & 0.13 & 0.13 \\
\hline \multirow{2}{*}{ Use } & Replacement Manufacturing & 0.14 & 0.11 & $\mathbf{0 . 2 4}$ \\
& Transportation Emissions & 0.01 & 0.01 & $\mathbf{0 . 0 1}$ \\
\hline \multirow{2}{*}{ End Of Life } & De-construction \& Demolition & -1.93 & -1.93 & $\mathbf{- 1 . 9 2}$ \\
& Transportation Emissions & 0.03 & 0.03 & 0.03 \\
\hline \multirow{2}{*}{ Total } & Non-Transport Emissions & -0.90 & -1.02 & $-\mathbf{0 . 2 6}$ \\
& Transport Emissions & $\mathbf{0 . 2 8}$ & 0.27 & 0.28 \\
\hline Note: & \multicolumn{4}{|c}{} \\
\hline \multicolumn{2}{l|}{ For each process, the highest value of the three locations is shown in bold. } & \\
\hline
\end{tabular}

Analysis of the reference building slab assembly indicated that nearly all of the impacts are incurred during the product manufacturing life cycle stage (Table 5-3). This is because the slab assembly is primarily comprised of concrete and EPS insulation, a petrochemical product. Influence of location on the product manufacturing GWP remains, but it is less pronounced than for the other two assemblies. Unlike the wall and roof assemblies, there is no sequestration of carbon at the end of life stage. 
Table 5-3 Summary of Reference Building Slab Assembly Embodied GWP

\begin{tabular}{|c|c|c|c|c|}
\hline Life Cycle Stage & Process & $\begin{array}{l}\text { Toronto } \\
\left(\mathrm{Mg} \mathrm{CO}_{2} \text { eq }\right)\end{array}$ & $\begin{array}{l}\text { Montreal } \\
\left(\mathrm{Mg} \mathrm{CO}_{2} \text { eq) }\right.\end{array}$ & $\begin{array}{l}\text { Edmonton } \\
\left(\mathrm{Mg} \mathrm{CO}_{2} \text { eq }\right)\end{array}$ \\
\hline \multirow{2}{*}{ Product } & Manufacturing & 4.87 & 4.69 & 5.38 \\
\hline & Transportation Emissions & 0.16 & 0.15 & 0.24 \\
\hline \multirow{2}{*}{ Construction Process } & Contruction-Installation & 0.47 & 0.47 & 0.50 \\
\hline & Transportation Emissions & 0.20 & 0.02 & 0.21 \\
\hline \multirow{2}{*}{ Use } & Replacement Manufacturing & 0.00 & 0.00 & 0.00 \\
\hline & Transportation Emissions & 0.00 & 0.00 & 0.00 \\
\hline \multirow{2}{*}{ End Of Life } & De-construction \& Demolition & 0.30 & 0.30 & 0.30 \\
\hline & Transportation Emissions & 0.10 & 0.10 & 0.10 \\
\hline \multirow{2}{*}{ Total } & Non-Transport Emissions & 5.64 & 5.46 & 6.19 \\
\hline & Transport Emissions & 0.46 & 0.45 & 0.54 \\
\hline
\end{tabular}

The product manufacturing stage was found to contribute the majority of emitted carbon for wall, roof and slab assemblies. All assemblies evaluated for Edmonton had the highest embodied GWP, while assemblies assessed for Montreal yielded the lowest embodied GWP results. Therefore, these processes can have a large impact on the material embodied GWP if the process consumes energy from a source with high carbon intensity. Edmonton has the highest electricity carbon intensity, while Montreal has the lowest carbon intensity (see Table 4-3), which is reflected in the results for assembly embodied GWP.

Athena IE accounts for material flows for each region available in its database through product market share analysis. Therefore, weighted averages of transportation distances and manufacturing impacts are used to represent the average product impact for each region (Athena, 2014a). Since transportation related GWP impacts were found to comprise only a small fraction of the total embodied GWP for wall, roof and slab assemblies, an emphasis on sourcing materials manufactured locally may not always result GWP reductions.

It is not uncommon for North American passive house designers to specify specialty envelope products sourced from Europe, including windows, tapes, insulating sheathing, and so called intelligent vapour retarders. Although this research did not consider the impact of products sourced from overseas, given the 
nature of these results, expanding the research to include imported products would help guide designers in making the best material selection.

\section{Impact of Insulation Choice on Embodied GWP}

Results of the analysis quantifying the impact of insulation material choice on embodied GWP are summarized in Table 5-4. For Toronto, an increase of $257 \%$ in total envelope embodied GWP was observed between the low and high-embodied GWP configurations. Changing wall assembly insulation materials from cellulose to fiberglass and changing slab assembly insulation from EPS to XPS contributed 45\% and $43 \%$ of the increase in total embodied GWP, while changing roof assembly insulation from cellulose to fiberglass contributed only $12 \%$. Changing slab assembly insulation had a much greater impact on embodied GWP than the other two assemblies when the comparison is made in relation to the total material volume.

Table 5-4 Impact of Envelope Insulation Material Type on Embodied GWP

\begin{tabular}{|c|c|c|c|c|c|}
\hline Assembly & $\begin{array}{l}\text { Configuration } 1 \\
\left(\mathrm{Mg} \mathrm{CO}_{2} \text { eq }\right)\end{array}$ & $\begin{array}{l}\text { Configuration } 2 \\
\left(\mathrm{MgCO}_{2} \text { eq }\right)\end{array}$ & $\begin{array}{l}\text { Difference } \\
\left(\mathrm{Mg} \mathrm{CO}_{2} \text { eq }\right)\end{array}$ & $\begin{array}{l}\text { Percent } \\
\text { Change } \\
(\%)\end{array}$ & $\begin{array}{l}\text { Volume Weighted } \\
\text { Difference } \\
\left(\mathrm{kg} \mathrm{CO}_{2} \mathrm{eq} / \mathrm{m}^{3}\right)\end{array}$ \\
\hline \multicolumn{6}{|l|}{ Toronto } \\
\hline Walls & -6.72 & -5.28 & 1.44 & $21 \%$ & 19.96 \\
\hline Roof & -0.62 & -0.23 & 0.39 & $63 \%$ & 7.31 \\
\hline Slab & 6.10 & 7.47 & 1.38 & $23 \%$ & 64.94 \\
\hline Total Envelope & -1.24 & 1.96 & 3.20 & $257 \%$ & - \\
\hline \multicolumn{6}{|l|}{ Montreal } \\
\hline Walls & -7.30 & -7.07 & 0.23 & $3 \%$ & 3.20 \\
\hline Roof & -0.75 & -0.79 & -0.04 & $-5 \%$ & -0.77 \\
\hline Slab & 5.91 & 7.25 & 1.34 & $23 \%$ & 63.05 \\
\hline Total Envelope & -2.13 & -0.61 & 1.52 & $71 \%$ & - \\
\hline \multicolumn{6}{|l|}{\begin{tabular}{|l} 
Edmonton \\
\end{tabular}} \\
\hline Walls & -3.89 & 1.14 & 5.03 & $129 \%$ & 69.89 \\
\hline Roof & 0.02 & 1.75 & 1.73 & $9622 \%$ & 32.47 \\
\hline Slab & 6.73 & 8.21 & 1.48 & $22 \%$ & 69.85 \\
\hline Total Envelope & 2.86 & 11.10 & 8.24 & $288 \%$ & - \\
\hline
\end{tabular}


Changing assembly insulation materials from Configuration 1 to 2 in Montreal resulted in an increase in total envelope embodied GWP of 71\%. Changing wall assembly insulation only slightly increased total embodied GWP (3\%), while changing roof insulation yielded a slight decrease in embodied GWP (-5\%). Substituting slab assembly insulation from EPS to XPS resulted in an increase of $88 \%$ of the total embodied GWP of the reference building. This is because manufacturing GWP of fiberglass is tied to regional electricity grid carbon intensity, while XPS manufacturing GWP is driven by blowing agent carbon intensity, which is consistent across all regions assessed. Slab assembly insulation was also dominant on a volumetric basis.

Results for Edmonton indicated that changing assembly insulation materials from Configuration 1 to 2 (defined on p. 35) significantly increases the total envelope embodied GWP (288\%). Changing wall assembly insulation from cellulose to fiberglass contributed the majority of the increase to total embodied GWP (61\%), while roof and slab assembly insulation changes made up less of the increase $(21 \%$ and $18 \%$ ). However, on a volumetric basis, wall and slab assembly insulation material choices have equal impacts on envelope embodied GWP.

The impact of wall and roof assembly insulation choice on embodied GWP varies between locations, with the greatest impact occurring in Edmonton and lowest impact in Montreal. This indicates a link between electricity grid carbon intensity and material embodied GWP, with the importance of considering embodied GWP of insulation being greatest for materials sourced from regions with high carbon electricity, such as Alberta. It also suggests that sourcing locally manufactured insulation in these regions could potentially result in greater embodied GWP than if insulation was imported from a region with low carbon electricity. The impact of insulation material choice on embodied GWP is almost negligible in regions supplied primarily by electricity generated from renewable sources, such as Quebec and British Columbia (Statistics Canada, 2014b; 2014d).

It is important to note that the results represent approximations of the specific building envelope configurations assessed. Documentation for Athena IE indicates that comparative assessments conducted for material substitutions are 
considered to produce results with uncertainties of $15 \%$ or less. Additionally, material take-offs were determined to be within $10 \%$ of actual manual take-off quantities (Athena, 2014a). Walls and roof structures evaluated were primarily comprised of wood, therefore the overall embodied GWP results would likely be significantly higher if other envelope types such as insulated concrete forms or structural insulating panels were used.

On a volumetric basis, slab insulation choice had the largest impact on embodied GWP. However, very little variation in the difference of slab insulation embodied GWP occurs between locations, suggesting that the impact is not dependent on regional electrical grid carbon intensity. Instead, it is likely due to the use of high GWP halocarbon blowing agents in the manufacture of XPS insulation (Harvey, 2007).

\section{Impact of Wall Cladding Choice on Embodied GWP}

Configurations 2 and 3 (defined on p. 35) were compared to assess the impact of cladding material selection on total envelope embodied GWP for each location. Only the wall cladding was changed between the two scenarios, with Configuration 2 using ship-lapped pine and Configuration 3 using residential grade, 30 gauge metal siding. Results presented in Table 5-5 indicate that wall cladding material choice can have a significant impact on overall envelope embodied GWP, with the largest increase occurring in Montreal (1400\%) and the smallest in Edmonton (70\%). These results are representative of the different maintenance and replacement requirements of each cladding material. This includes region specific differences in maintenance frequency, energy use and on-site waste associated with maintenance (Athena, 2014a). However, the magnitude of impact that cladding material choice has on embodied GWP is similar in all three locations. Steel was used to represent the metal cladding in Athena IE (Ibid.). Therefore, the lack of variation between locations is likely due to the use of coke in steel manufacturing, which comprises the bulk of the materials embodied GWP impacts (U.S. Environmental Protection Agency, 2003). This suggests that regional electricity grid carbon intensity is not the 
primary driver of metal cladding embodied GWP, although it could account for the small differences between locations. However, it should be noted that other cladding types not included in the analysis could exhibit regional variation in embodied GWP, especially materials requiring significant input of electricity during their manufacture. Although metals are highly durable and recyclable, the energy and thus carbon penalty incurred during the initial manufacturing and end of service life reprocessing is not recuperated.

Table 5-5 Impact of Wall Cladding Material on Total Envelope Embodied GWP

\begin{tabular}{|c|c|c|c|c|}
\hline Location & $\begin{array}{l}\text { Configuration } 2 \\
\left(\mathrm{Mg} \mathrm{CO}_{2} \text { eq }\right)\end{array}$ & $\begin{array}{l}\text { Configuration } 3 \\
\left(\mathrm{Mg} \mathrm{CO}_{2} \mathrm{eq}\right)\end{array}$ & $\begin{array}{l}\text { Difference } \\
\left(\mathrm{Mg} \mathrm{CO}_{2} \text { eq }\right)\end{array}$ & $\begin{array}{l}\text { Difference } \\
(\%) \\
\end{array}$ \\
\hline Toronto & 1.96 & 10.22 & 8.27 & $422 \%$ \\
\hline Montreal & -0.61 & 7.91 & 8.52 & $1399 \%$ \\
\hline Edmonton & 11.10 & 18.66 & 7.57 & $68 \%$ \\
\hline
\end{tabular}

A comparison of the results for reference building wall assembly insulation and cladding material choices on embodied GWP was made to determine the assembly layer with the largest impact. Results presented in Table 5-6 indicate that choice of wall cladding material has a much greater impact on envelope embodied GWP than choice of insulation in Toronto or Montreal, while wall cladding and insulation material choices have similar impacts on reference building embodied GWP in Edmonton. These results indicate that wall cladding material choice should be carefully considered in all locations across Canada when designing low carbon building envelopes. Additionally, insulation material choice does not have a large impact on overall envelope embodied GWP in locations with low carbon electricity sources. 
Table 5-6 Results of Reference Building Assembly Material Substitution Analysis

\begin{tabular}{|l|lllr|}
\hline Location & $\begin{array}{l}\text { Difference in } \\
\text { Insulation } \\
\text { Configurations } \\
\left(\mathrm{Mg} \mathrm{CO}_{2} \text { eq }\right)\end{array}$ & $\begin{array}{l}\text { Difference in } \\
\text { Cladding } \\
\text { Configurations } \\
\left(\mathrm{Mg} \mathrm{CO}_{2} \text { eq }\right)\end{array}$ & $\begin{array}{l}\text { Cumulative Difference in } \\
\text { Insulation and Cladding } \\
\text { Configurations } \\
\left(\mathrm{Mg} \mathrm{CO}_{2} \text { eq }\right)\end{array}$ & \\
\hline Toronto & 3.20 & 8.27 & 11.47 \\
Montreal & 1.52 & 8.52 & 10.04 \\
Edmonton & 8.24 & 7.57 & 15.81 \\
\hline
\end{tabular}

\subsubsection{Operating Energy Consumption and Operating GWP}

An analysis of the impact that location and mechanical system fuel selection have on operating energy consumption and GWP was conducted for the reference building envelope defined in Table 4-4 and mechanical systems described in Table 4-7. The impact that location has on energy consumption was determined through examination of the WUFI Passive whole building energy modeling results. Total life cycle operating energy consumption for each location and mechanical system combination is shown in Figure 5-1. These results represent energy consumed on-site and do not factor in losses associated with energy generation or distribution. Since all factors other than location were kept the same, results for each mechanical system case are representative of the impact that climate has on energy consumption. 


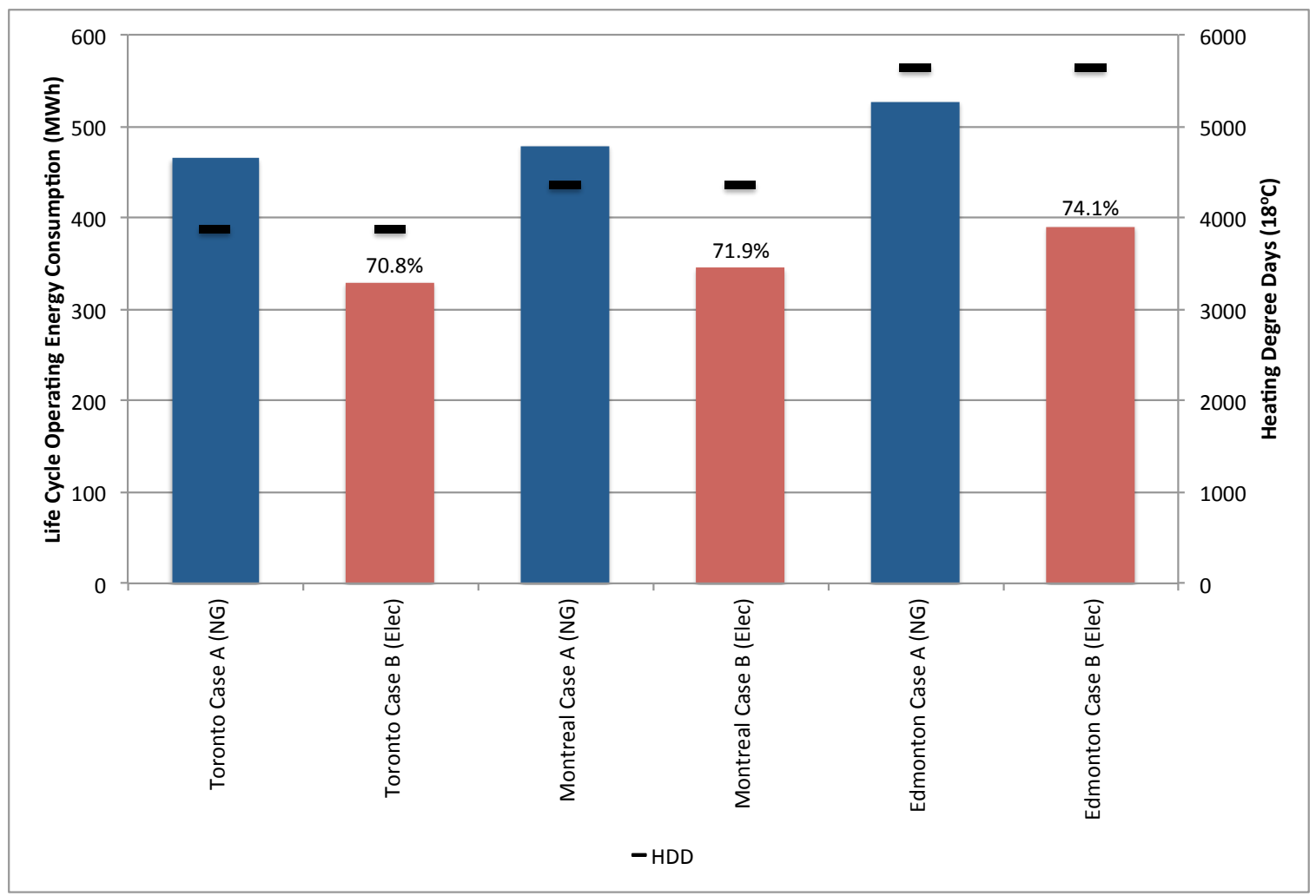

Figure 5-1 Impact of Location and Mechanical System Choice on Life Cycle Operating Energy Consumption

Case A (NG) energy consumption results are higher than Case B (Electric) for all locations. Over the lifetime of the building, a Case B (Electric) mechanical system would consume $70.8 \%, 71.9 \%$ and $74.1 \%$ of the site energy of Case A (NG) for Toronto, Montreal, and Edmonton, respectively. This is due to the use of heat pump mechanical systems in Case B (Electric). The air-to-air heat pump system selected uses electrical energy to move heat from outside air to the conditioned space with COPs greater than 1 . Therefore, heat pumps require less site energy than natural gas equipment to cover the same space heating demand. It should be noted that the advantage in efficiency of energy conversion held by Case B (Electric) is lost when factoring in the conversion from source energy to site energy. The difference is even more important in locations where the majority of electricity is generated through combustion of thermal fuels, since a large proportion of energy in the fuel is lost as heat during conversion to electricity, while natural gas mechanical heating systems convert the fuel directly into heat with very high efficiency. 
For both Cases A and B, Toronto had the lowest energy consumption, while Edmonton had the highest. This is due to Toronto having the lowest number of heating degree days (3873) compared with Montreal (4363) and Edmonton (5637) and consequently the lowest annual heat demand of the three locations assessed (Table 5-7).

Table 5-7 Annual Heat Demand and Heating Degree Days for Assessed Locations

\begin{tabular}{|l|lll|}
\hline Location & $\begin{array}{l}\text { Life Cycle } \\
\text { Operating Energy } \\
\text { Consumption } \\
\text { (MWh) }\end{array}$ & Heating Degree Days \\
\hline Toronto & & 329 & \\
Montreal & 345 & 4873 \\
Edmonton & 390 & 5637 \\
\hline
\end{tabular}

Figure 5-2 compares the impact that location and mechanical system choice have on building life cycle operating GWP. The reference building modeled for Edmonton with Case A (NG) mechanicals had higher life cycle operating GWP than Toronto (225\%) and Montreal (358\%), while the same building with Case B (Electric) mechanicals had $432 \%$ and $6,610 \%$ greater emissions than Toronto and Montreal, respectively. The reference building modeled for Montreal had the lowest operating GWP impact for both mechanical system types, despite having higher operating energy consumption than Toronto for both Case A (NG) and B (Figure 5-1). This is due to Montreal having access to electricity with the lowest carbon intensity of the three locations. Even for Case A (NG), where heat and hot water are supplied via natural gas, the lower carbon intensity of the electricity used to power the auxiliary equipment in Montreal results in sufficient reductions to overcome the impact of additional GWP arising from the higher heating requirements. 


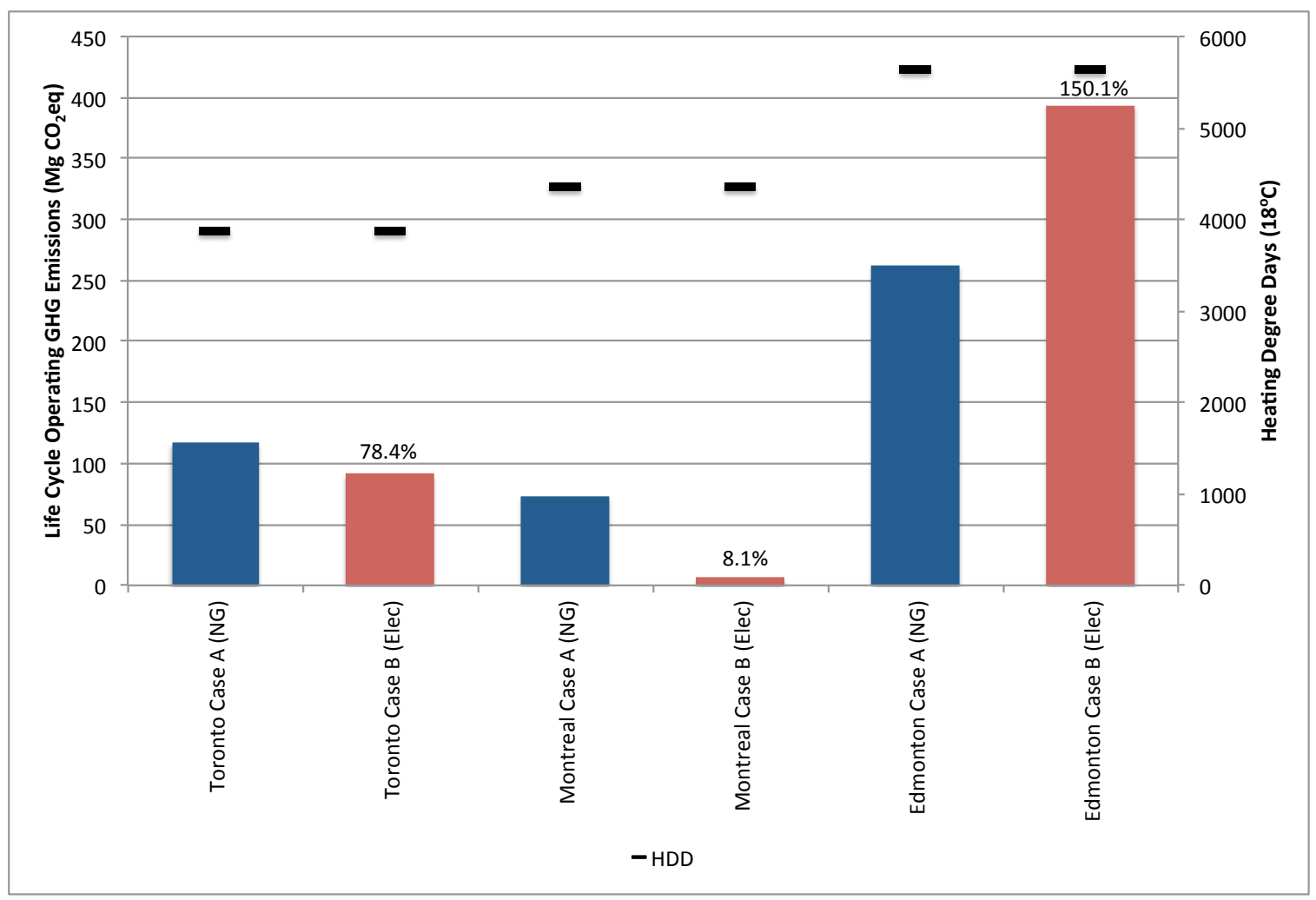

Figure 5-2 Impact of Location and Mechanical System Choice on Life Cycle Operating GWP

Natural gas-fuelled (Case A) mechanicals produced higher life cycle operating GWP than electricity-based mechanical systems (Case B) for both Toronto (116 vs. $91 \mathrm{MgCO}_{2} \mathrm{eq}$ ) and Montreal (73 vs. $6 \mathrm{MgCO}_{2} \mathrm{eq}$ ). Case B (Electric) was found to generate only $78.4 \%$ and $8.1 \%$ of the emissions of Case A (NG) for Toronto and Montreal, respectively. However, the opposite is true in Edmonton (262 vs. 394 $\mathrm{MgCO}_{2} \mathrm{eq}$ ), where the Case B (Electric) mechanical system generated $150.1 \%$ greater GWP compared to the Case A (NG) system. Despite the efficiency of heat pump electric mechanicals, their application in regions with high carbon electricity sources yielded greater operating GWP than natural gas mechanical systems.

These findings reflect the current carbon intensities of electrical grids and natural gas for the locations assessed. As regional energy supplies change, so to will their carbon impacts. Athena IE electricity generation carbon intensity values used to determine the operating GWP account for upstream impacts due to primary extraction of the resource consumed, along with production, delivery and use of electricity (Athena, 2014a). Life cycle carbon intensity values used by Athena IE are 
included in Table 5-8, along with the historic downstream electricity carbon intensities. Historic downstream values from Environment Canada (2014b) presented in the Table are significantly different from Athena IE values due to differences in life cycle system boundaries used in the respective emissions accounting methods. Environment Canada values only account for carbon emissions incurred during electricity production and transportation, thereby excluding any upstream impacts from resource extraction and processing (Environment Canada, 2014c). However, these historic values were included to illustrate that electricity carbon intensities can change greatly in a short period of time.

Table 5-8 Historic and Life Cycle Carbon Intensities of Electricity

\begin{tabular}{|c|c|c|c|c|c|c|c|c|c|}
\hline Province & & istoric $\mathrm{E}$ & ectrici & $\begin{array}{l}\text { Gene } \\
\mathrm{CO}_{2} \mathrm{e}\end{array}$ & $\begin{array}{l}\text { ation C } \\
\text { /kWh) }\end{array}$ & rbon In & tensity $^{1}$ & & $\begin{array}{c}\text { Athena IE } \\
\text { (g CO } \mathrm{g}_{2} \text { eq/kWh) }\end{array}$ \\
\hline Year & 1990 & 2000 & 2005 & 2008 & 2009 & 2010 & 2011 & 2012 & 2012 \\
\hline Ontario & 220 & 320 & 240 & 170 & 120 & 150 & 100 & 110 & 277 \\
\hline Quebec & 14.0 & 4.0 & 4.1 & 2.9 & 4.0 & 2.9 & 2.6 & 3.6 & 17 \\
\hline Alberta & 1000 & 1000 & 980 & 1200 & 1100 & 1000 & 1000 & 910 & 1100 \\
\hline \multicolumn{10}{|l|}{ Notes: } \\
\hline
\end{tabular}

In Ontario for example, the carbon intensity dropped 66\% in 10 years, which is well within the life span of mechanical equipment. This would significantly impact the operating emissions outcome of a building and potentially change the importance of decisions made during the building design phase. Thus, decisions made about mechanical systems should reflect both current and anticipated carbon intensities of the energy carrier selected over the expected lifespan of the equipment.

It should also be noted that since this analysis was limited to examining the climate impacts of only two mechanical systems, inclusion of other heating systems and examination of additional environmental indicators might yield different findings. Nevertheless, the finding that large difference in operating GWP between 
locations and mechanical system scenarios exist indicates that a regional based method for determining operating GWP is undoubtedly required.

\section{Significance of Envelope Life Cycle Embodied GWP and Operating GWP}

Results comparing envelope embodied GWP with operating GWP for Toronto, Montreal and Edmonton are summarized in Figure 5-3. The significance of envelope embodied GWP was evaluated in terms of net life cycle GWP emissions of the envelope (herein referred to as life cycle GWP), which includes building operating GWP.

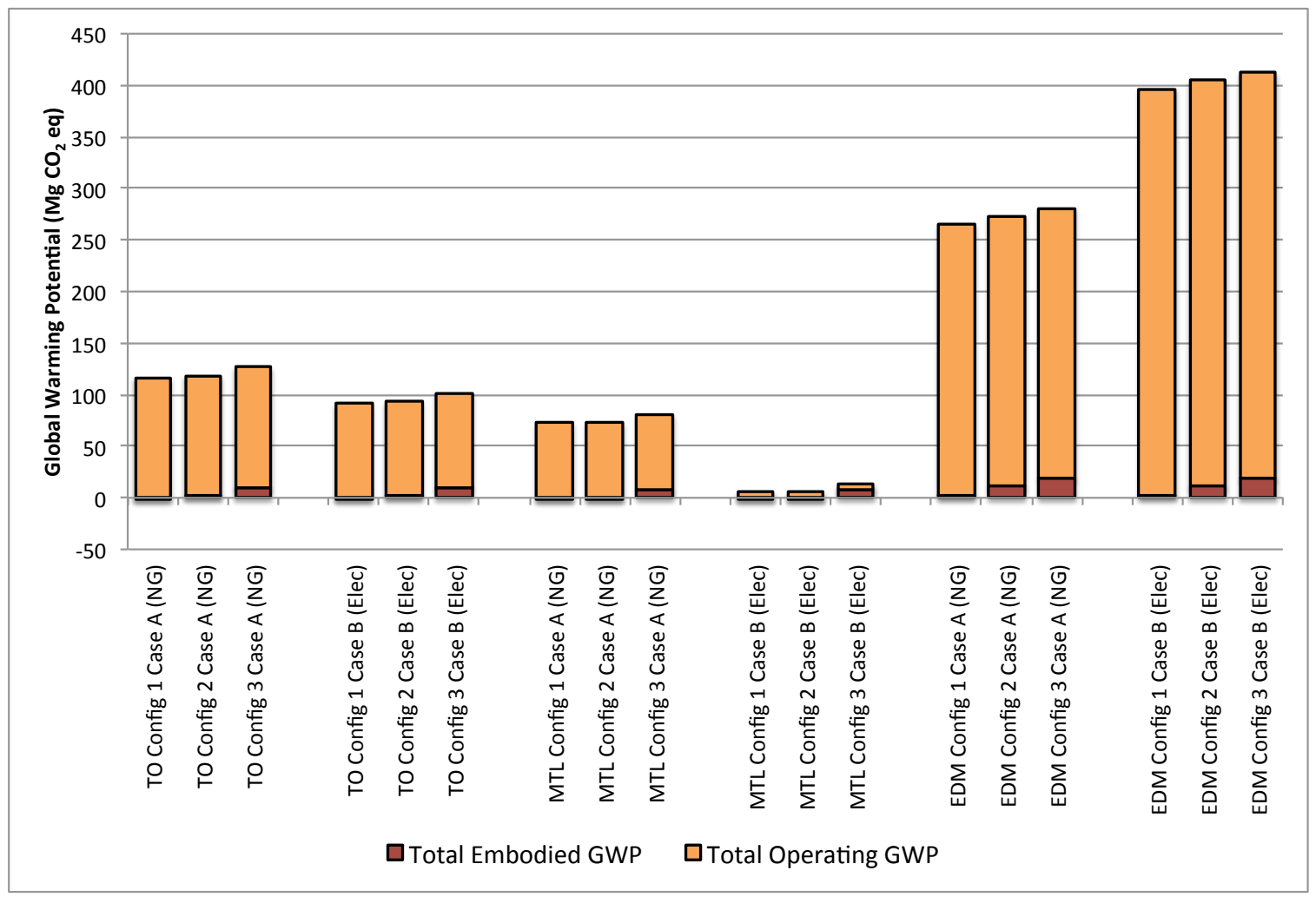

Figure 5-3 Impact of Location and Mechanical System Type on Embodied and Operating GWP

The relative significance of envelope embodied GWP compared to the total operating GWP for each envelope material configuration is summarized in Table $5-9$. 
Table 5-9 Summary of Envelope Embodied Impacts Compared to Operating GWP

\begin{tabular}{|c|c|c|c|c|c|c|c|}
\hline \multirow{3}{*}{ Location } & \multirow{3}{*}{$\begin{array}{l}\text { Mechanical } \\
\text { System }\end{array}$} & \multicolumn{6}{|c|}{ Impact of Embodied GWP on LC GWP } \\
\hline & & \multicolumn{2}{|c|}{ Configuration 1} & \multicolumn{2}{|c|}{ Configuration 2} & \multicolumn{2}{|c|}{ Configuration 3} \\
\hline & & $\begin{array}{l}\text { Embodied } \\
\text { (\% of Total) }\end{array}$ & $\begin{array}{c}\text { LC GWP } \\
\left(\mathrm{Mg} \mathrm{CO}_{2} \text { eq }\right)\end{array}$ & $\begin{array}{l}\text { Embodied } \\
\text { (\% of Total) }\end{array}$ & $\begin{array}{c}\text { LC GWP } \\
\left(\mathrm{Mg} \mathrm{CO}_{2} \text { eq }\right)\end{array}$ & $\begin{array}{l}\text { Embodied } \\
\text { (\% of Total) }\end{array}$ & $\begin{array}{c}\text { LC GWP } \\
\left(\mathrm{Mg} \mathrm{CO}_{2} \text { eq }\right)\end{array}$ \\
\hline Toronto & Case A (NG) & $-1.1 \%$ & 115.2 & $1.7 \%$ & 118.4 & $8.8 \%$ & 126.6 \\
\hline Toronto & Case B (Elec) & $-1.4 \%$ & 90.0 & $2.1 \%$ & 93.2 & $11.2 \%$ & 101.4 \\
\hline Montreal & Case A (NG) & $-2.9 \%$ & 70.5 & $-0.8 \%$ & 72.0 & $10.9 \%$ & 80.5 \\
\hline Montreal & Case B (Elec) & $-35.8 \%$ & 3.8 & $-10.2 \%$ & 5.3 & $132.9 \%$ & 13.9 \\
\hline Edmonton & Case A (NG) & $1.1 \%$ & 265.1 & $4.2 \%$ & 273.3 & $7.1 \%$ & 280.9 \\
\hline Edmonton & Case B (Elec) & $0.7 \%$ & 396.5 & $2.8 \%$ & 404.7 & $4.7 \%$ & 412.3 \\
\hline
\end{tabular}

For Configuration 1, envelope assemblies in both Toronto and Montreal have a damping influence on life cycle GWP for each mechanical system permutation, with the negative embodied GWP resulting in a decrease in life cycle GWP. The largest damping effect occurs in Montreal for the electrically powered mechanical system (Case B), where the envelope decreases the total life cycle GWP by $36 \%$. This is due to the all-electric mechanical system consuming electricity from a grid with very low carbon intensity, resulting in low operating GWP. The reference building located in Edmonton with natural gas mechanicals yielded the largest increase in GWP relative to the other permutations assessed for Configuration 1. However, at only $1 \%$ of life cycle GWP, the impact of the envelope embodied GWP is insignificant when compared with operating GWP. Therefore, the combination of low embodied GWP insulation and cladding can help to reduce the overall life cycle carbon burden of buildings and even negate some of the operating impacts in locations with low carbon electricity.

Envelope embodied GWP in envelope Configuration 2, which was comprised of high-embodied GWP insulation and low embodied GWP cladding, yielded slightly larger impacts on life cycle GWP for Toronto and Edmonton. However, permutations for both mechanical system cases in Montreal still reduced the overall life cycle GWP with respect to operating GWP, with Case B (Electric) again yielding a large reduction in total emissions of $10 \%$. For Toronto and Edmonton, the proportion of 
life cycle emissions attributable to the building envelope ranged between $2 \%$ and $4 \%$, which was still insignificant compared to the impact of operating GWP.

Results for all permutations using envelope Configuration 3, with high embodied GWP insulation and cladding, increased the overall life cycle GWP. At 133\%, embodied GWP had the largest effect on life cycle GWP in Montreal for heat pump electric mechanical systems due to the very low operating GWP of this scenario. Envelope embodied GWP was lowest relative impact on life cycle GWP for the scenario in Edmonton using electric mechanical systems (5\%), due to the very high operating GWP for this case.

These results indicate that envelope embodied GWP does not have a significant impact when compared to operating emissions for all locations and mechanical systems except for the Case B (Electric) mechanical system in Montreal. Therefore, as the operating GWP impacts are reduced, embodied impacts become increasingly significant and deserve attention when attempting to minimize the life cycle carbon impact of buildings. However, since the envelope embodied accounting in this study was limited in that the data for materials is based on aggregated values representing average regional embodied impacts, the findings should not be universally extended to all buildings constructed to the Passive House Standard. Rather, a full accounting of the life cycle impacts of the building envelope should be undertaken using the best available data for the specific materials selected in order to determine the GWP impact specific to the building.

These results excluded the impact of high performance windows, which would have lead to an increase in the overall embodied GWP of the envelope. Furthermore, including embodied impacts of interior finishes, fixtures, appliances and mechanical systems in the assessment would also result in a significant increase in overall embodied GWP. Studies by Passer et al. (2012) and Stephan, Crawford, and de Myttenaere (2013) comparing operating and embodied impacts of buildings constructed to the Passive House Standard have determined that whole building embodied impacts can make up a significant proportion of the total life cycle impact. The extent to which the embodied GWP of these non-envelope related materials would increase is highly dependent on the type and nature of the materials and 
finishes selected. For example, the study by Passer et al. (2012) found that embodied energy of building materials in a Passive House made up $31 \%$ of the total life cycle impact, while the study by Stephan, Crawford, and de Myttenaere (2013) indicated that embodied energy was up to $77 \%$ of the total energy used over the life cycle of Passive Houses.

If the carbon sequestration effect of wood based materials in the wall and roof assemblies were excluded, the impact of envelope embodied GWP relative to operating emissions would be increased by $13 \mathrm{MgCO}_{2}$ eq for envelope Configuration 1 in all locations. Configurations 2 and 3 would increase to a lesser degree since they do not incorporate cellulose insulation, however the impact from the structural wood based materials would remain. Therefore the gap in embodied GWP between the three configurations assessed would decrease.

\subsubsection{Comparison of Passive House Standard and Regional Based Method Operating GWP Results}

The difference between Passive House Standard and Athena IE calculated operating GWP was determined for each location and mechanical system combination.

A comparison of modeling results for natural gas mechanical systems revealed that the Passive House Standard calculation method significantly overestimates operating GWP for Montreal, while underestimating emissions for Edmonton (Table 5-10). Emissions for Toronto were also overestimated, although to a lesser extent than for Montreal. Athena IE and the Passive House Standard method both assume a constant natural gas carbon emission factor for all of the locations assessed. Therefore, the difference in predicted operating GWP between the two calculation methods found is entirely due to the electrical portion of the energy consumed. The Passive House Standard calculation method assumes a single electricity carbon emission factor and therefore fails to capture the regional differences in electricity carbon intensity. 
Table 5-10 Case A (NG): Comparison of Athena IE and WUFI Passive Results for Operating Greenhouse Gas Emissions

\begin{tabular}{|l|lll|}
\hline Location & $\begin{array}{l}\text { Athena IE Life } \\
\text { Cycle Operating } \\
\text { GHG Emissions } \\
\text { (Mg CO }\end{array}$ eq) & $\begin{array}{l}\text { WUFI Passive Life } \\
\text { Cycle Operating } \\
\text { GHG Emissions } \\
(\mathrm{Mg} \mathrm{CO} \text { eq })\end{array}$ & $\begin{array}{l}\text { Percent Difference } \\
\text { Between Athena IE \& } \\
\text { WUFI Passive Results } \\
(\%)\end{array}$ \\
\hline Toronto & 116 & 186 & $60 \%$ \\
Montreal & 73 & 190 & $159 \%$ \\
Edmonton & 262 & 201 & $-23 \%$ \\
\hline
\end{tabular}

A comparison of Athena IE and WUFI Passive results for all-electric mechanical systems in Table 5-11 produced even larger deviations in predicted operating GWP than for the natural gas mechanicals. The Passive House Standard calculation method overestimates operating GWP for Montreal by a significant margin, while again moderately underestimating emissions for Edmonton. Emissions for Toronto were also overestimated, although to a lesser extent than for Montreal. Deviations in the results predicted by the Passive House Standard calculation method are greatest for heat pump electric mechanical systems. Additionally, the Passive House Standard method predicts that selecting Case B (Electric) mechanicals would result in higher operating GWP than for Case A (NG) mechanicals in Toronto and Montreal, which is opposite of what is predicted by Athena IE. Consequently, designers cannot rely on using WUFI Passive to make decisions regarding optimization of building operating GWP.

Table 5-11 Case B (Electric): Comparison of Athena IE and WUFI Passive Results for Operating GWP

\begin{tabular}{|l|llr|}
\hline Location & $\begin{array}{l}\text { Athena IE Life } \\
\text { Cycle Operating } \\
\text { GHG Emissions } \\
(\mathrm{Mg} \mathrm{CO} \text { eq })\end{array}$ & $\begin{array}{l}\text { WUFI Passive Life } \\
\text { Cycle Operating } \\
\text { GHG Emissions } \\
(\mathrm{Mg} \mathrm{CO} \text { eq })\end{array}$ & $\begin{array}{l}\text { Percent Difference } \\
\text { Between Athena IE \& } \\
\text { WUFI Passive Results } \\
(\%)\end{array}$ \\
\hline Toronto & 91 & 215 & $135 \%$ \\
Montreal & 6 & 226 & $3700 \%$ \\
Edmonton & 394 & 261 & $-34 \%$ \\
\hline
\end{tabular}


Due to geographic variations in the North American electricity generation mix and the segregation of the electricity grid into several distinct regions, it is recommended that the Passive House Standard be revised to include region specific energy carbon intensities. Additionally, research should be conducted into methods for projecting future energy source carbon intensities to allow for increased accuracy when predicting life cycle operating carbon impacts. Implementing these changes would provide designers with a tool that for making informed decisions when evaluating available mechanical system options and would increase confidence that the primary purpose of the standard is upheld regardless of location.

\subsection{Envelope Parametric Analysis Results}

\subsubsection{Impact of Insulation Thickness on Envelope Embodied GWP}

Assessment of the wall assembly for Configuration 1 yielded envelope embodied GWP results with negative values for wood-clad assemblies with blown-in cellulose insulation, indicating sequestration of carbon (Figure 5-4, Figure 5-5 and Figure 5-6). Additionally, as insulation thickness is increased, the amount of embodied GWP is reduced. An exception to this trend occurs at $280 \mathrm{~mm}$ of insulation thickness, where the amount of embodied GWP of the wall assembly is increased. At this point $(280 \mathrm{~mm})$, the exterior non-structural wall was increased from a thickness of $89 \mathrm{~mm}$ to $140 \mathrm{~mm}$ deep. Beyond a thickness of $280 \mathrm{~mm}$, the exterior wall structure is changed from dimensional lumber to manufactured I-joists.

For the wood-clad assemblies with blown-in fiberglass insulation (Configuration 2), the wall assembly results in negative embodied GWPs in both Toronto and Montreal, indicating that sequestration of carbon occurs (Figure 5-7, Figure 5-8 and Figure 5-9), however the same assembly modeled for Edmonton results in positive GWP values for most insulation thicknesses, indicating a net emission of carbon into the atmosphere (Figure 5-10). Configuration 2 in Toronto exhibits a flat trend of GWP with increasing insulation thickness after approximately $380 \mathrm{~mm}$ of insulation, while Montreal has an overall reducing trend. Meanwhile, the 
same assembly configuration in Edmonton results in an overall increasing trend. Montreal has the best outcome in assembly embodied GWP, followed by Toronto, while Edmonton has the poorest outcome.

Metal-clad wall assemblies with blown-in fiberglass insulation (Configuration 3) resulted in the highest GWP impact of the three wall assembly configurations assessed. All iterations yielded positive envelope embodied GWP values for all locations (Figure 5-4, Figure 5-5 and Figure 5-6), indicating net emission of carbon into the atmosphere. Configuration 3 in Toronto and Montreal results in an overall decreasing trend in GWP with increasing insulation thickness, while Edmonton has an overall increasing trend.

Wall assembly cladding selection was found to have a greater impact on wall assembly embodied GWP than choice of insulation material for all iterations in Toronto and Montreal. In Edmonton, wall-cladding materials have the greatest impact on GWP until an insulation thickness of approximately $500 \mathrm{~mm}$. Beyond 500 $\mathrm{mm}$, the insulation material choice has a larger and increasing influence on embodied GWP.

Dimensional lumber and manufactured I-joists used in the wall assemblies help to reduce the embodied GWP of the envelope, even when using insulation materials with high embodied GWP. Electricity grid carbon intensity is the primary reason for regional differences in embodied GWP impact, while material manufacturing energy intensity is the reason for differences between the three assembly configurations, as previously established through the detailed investigation in Section 5.1 .1 (p. 54).

These results are limited in application to the wall assembly assessed, and due to the high proportion of dimensional lumber used relative to the envelope volume, likely represents a best case for embodied GWP. Extending this research to other envelope types would prove valuable, since Passive Houses can be constructed using other wall assemblies that are comprised of significantly different materials, including structural insulating panels, insulated concrete forms, and exterior insulated concrete masonry units. 


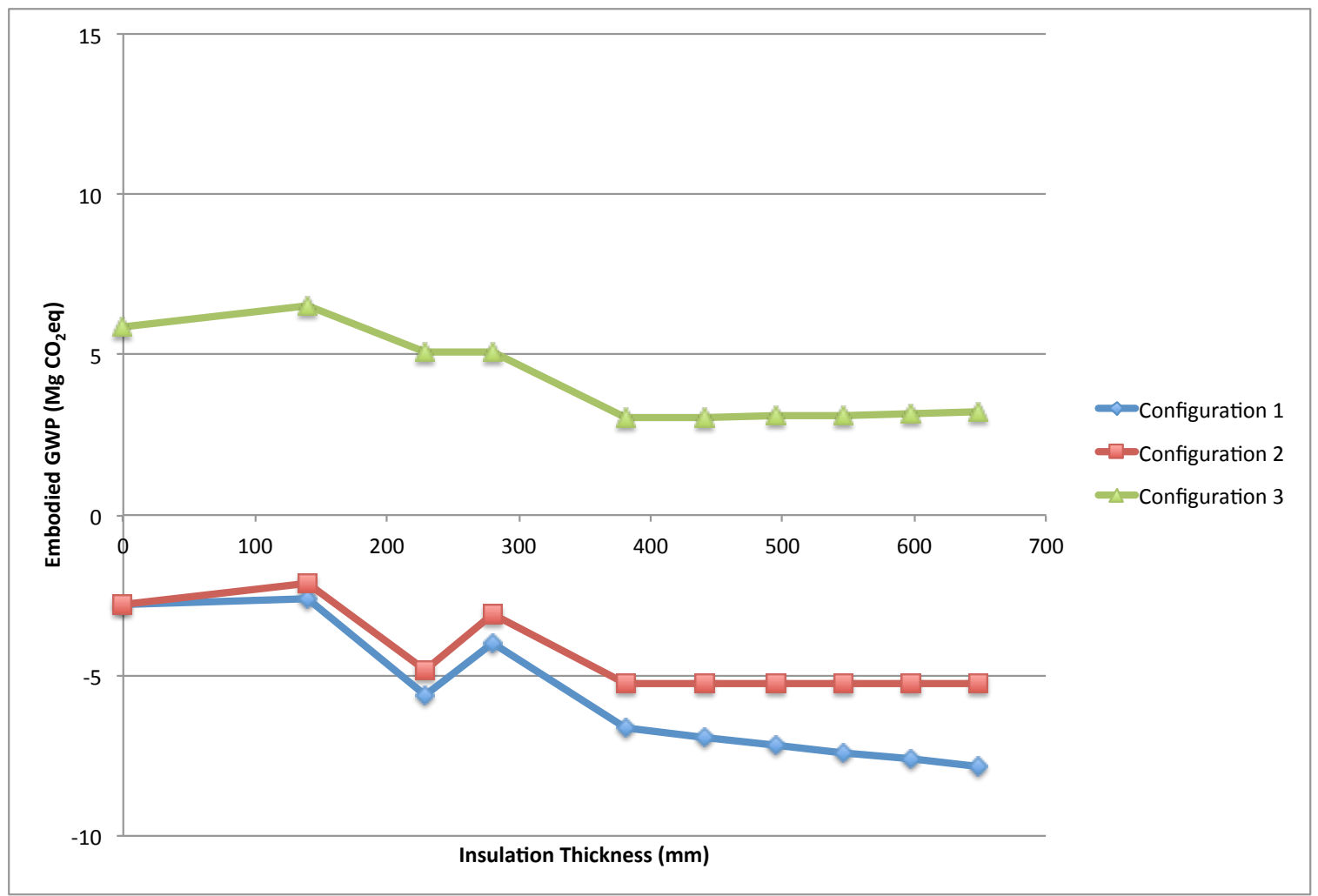

Figure 5-4 Comparison of Toronto Wall Assembly Material Type Embodied GWP

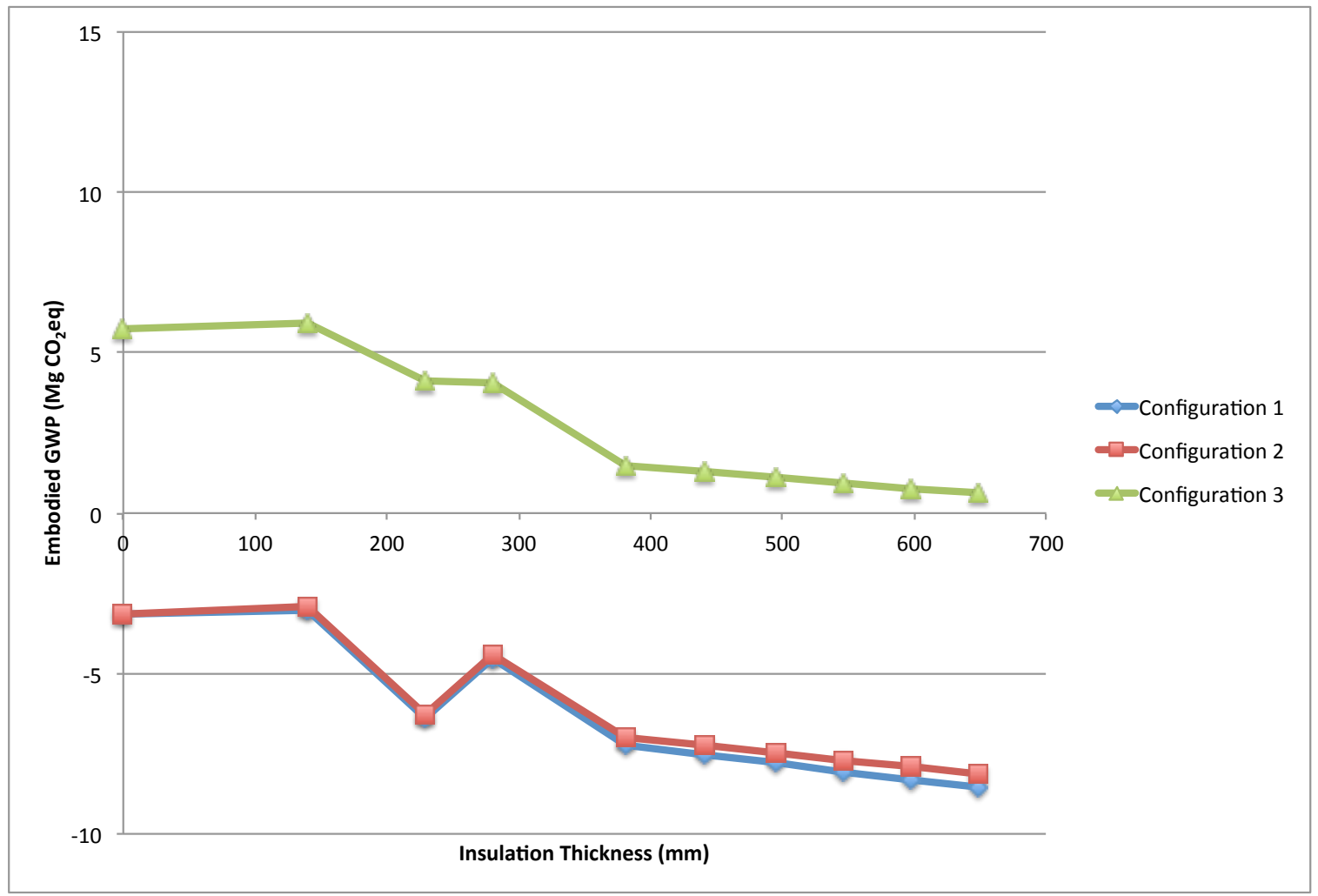

Figure 5-5 Comparison of Montreal Wall Assembly Material Type Embodied GWP 


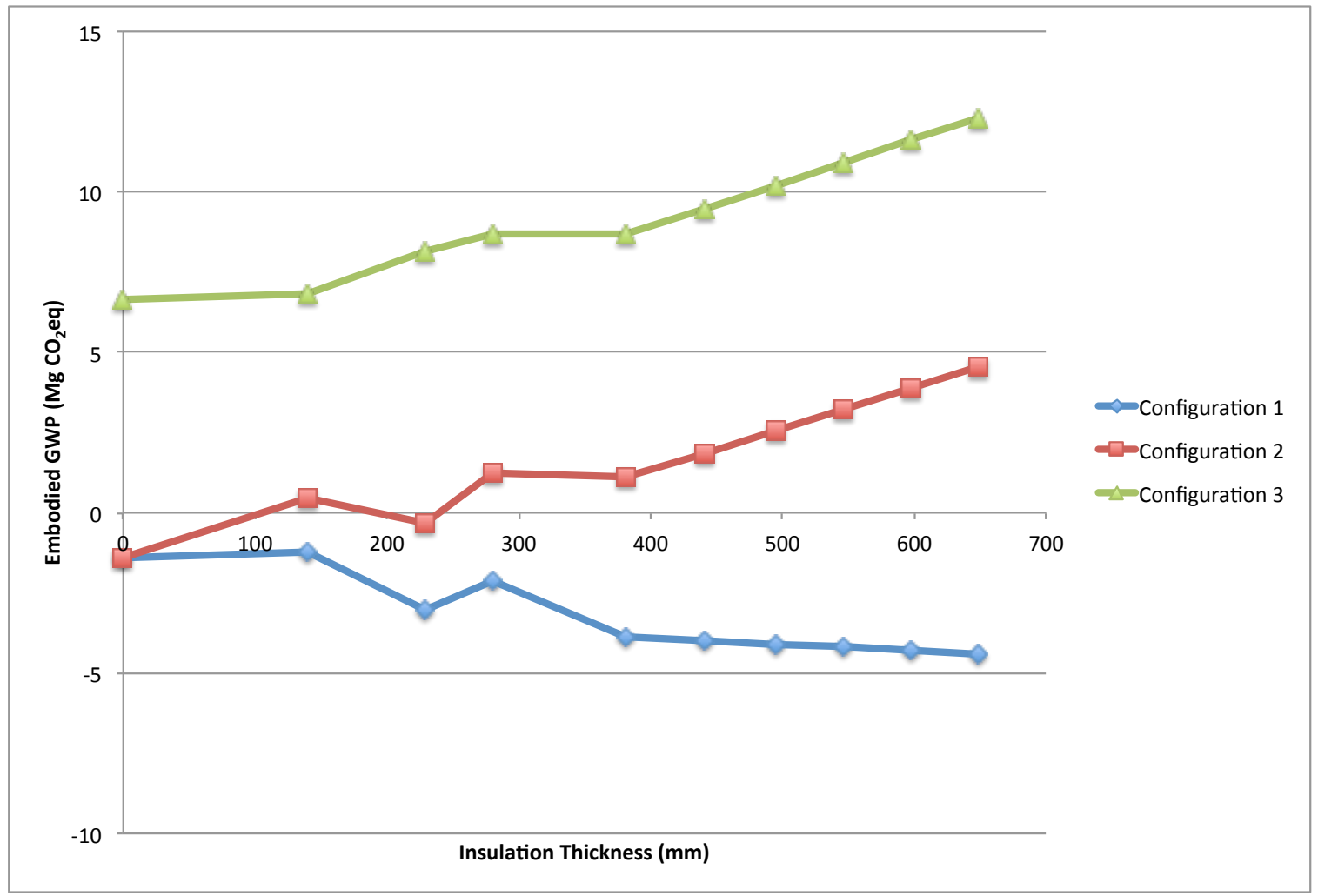

Figure 5-6 Comparison of Edmonton Wall Assembly Material Type Embodied GWP

The roof assembly embodied GWP was assessed for both blown-in cellulose and blown-in fiberglass insulation. No changes to the cladding materials of the roof assembly were made. Iterations of the roof assembly containing blown-in cellulose yielded negative values for both Toronto and Montreal (Figure 5-7 and Figure 5-8). However, the same insulation levels modeled for Edmonton transitioned from a negative GWP at a thickness of approximately $600 \mathrm{~mm}$ (Figure 5-9).

Fiberglass insulation was then substituted into the roof assembly in place of cellulose, yielding higher GWP in Toronto and significantly higher GWP in Edmonton. Although the same insulation levels modeled for Montreal resulted in slightly lower embodied GWP beyond an insulation thickness of approximately 400 $\mathrm{mm}$, the difference between fiberglass and cellulose GWPs were only minor. All three locations exhibited increases to GWP with increasing cellulose insulation thickness, with only the assembly in Montreal able to sequester carbon for all iterations tested. The roof assembly was found to only have a significant impact on 
embodied GWP for locations with high carbon electricity when using fiberglass insulation.

Embodied GWP for all three locations and both insulation materials exhibited increasing trends with increasing cellulose insulation thickness, with the exception of a single decrease at $140 \mathrm{~mm}$ in all but Configuration 2 in Edmonton. The reason for this trend is that a change in the ceiling joist size occurs at $140 \mathrm{~mm}$ of insulation, thus using additional lumber which reduces the overall embodied GWP. Beyond the $140 \mathrm{~mm}$ point, the quantity of insulation is increased but the structure is kept the same. Since the insulation materials are more energy intensive to produce than lumber, adding more insulation to the assembly results in an increase in embodied GWP. This indicates that even cellulose insulation in Configuration 1 can increase the embodied carbon of the building. 


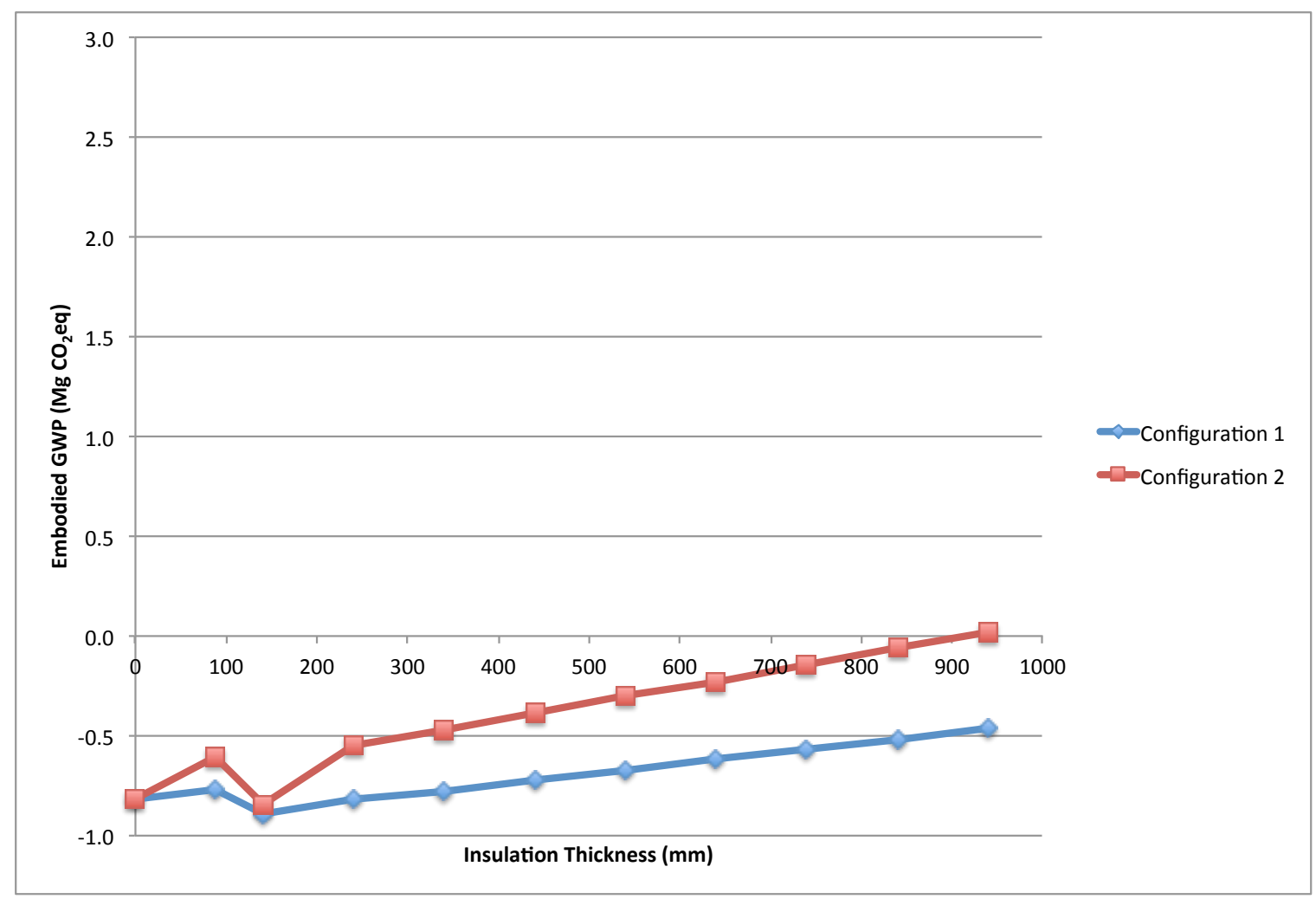

Figure 5-7 Comparison of Toronto Roof Assembly Insulation Type Embodied GWP

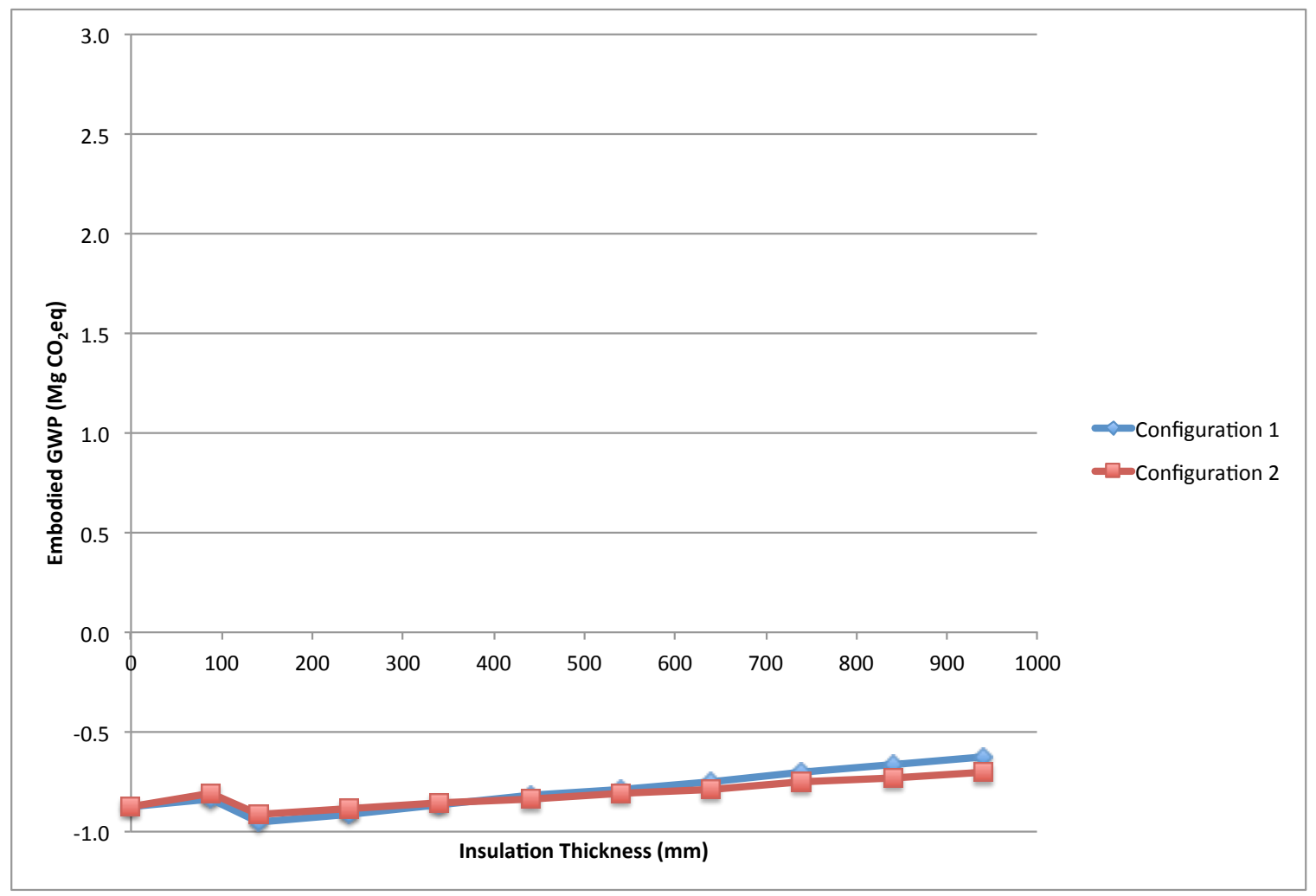

Figure 5-8 Comparison of Montreal Roof Assembly Insulation Type Embodied GWP 


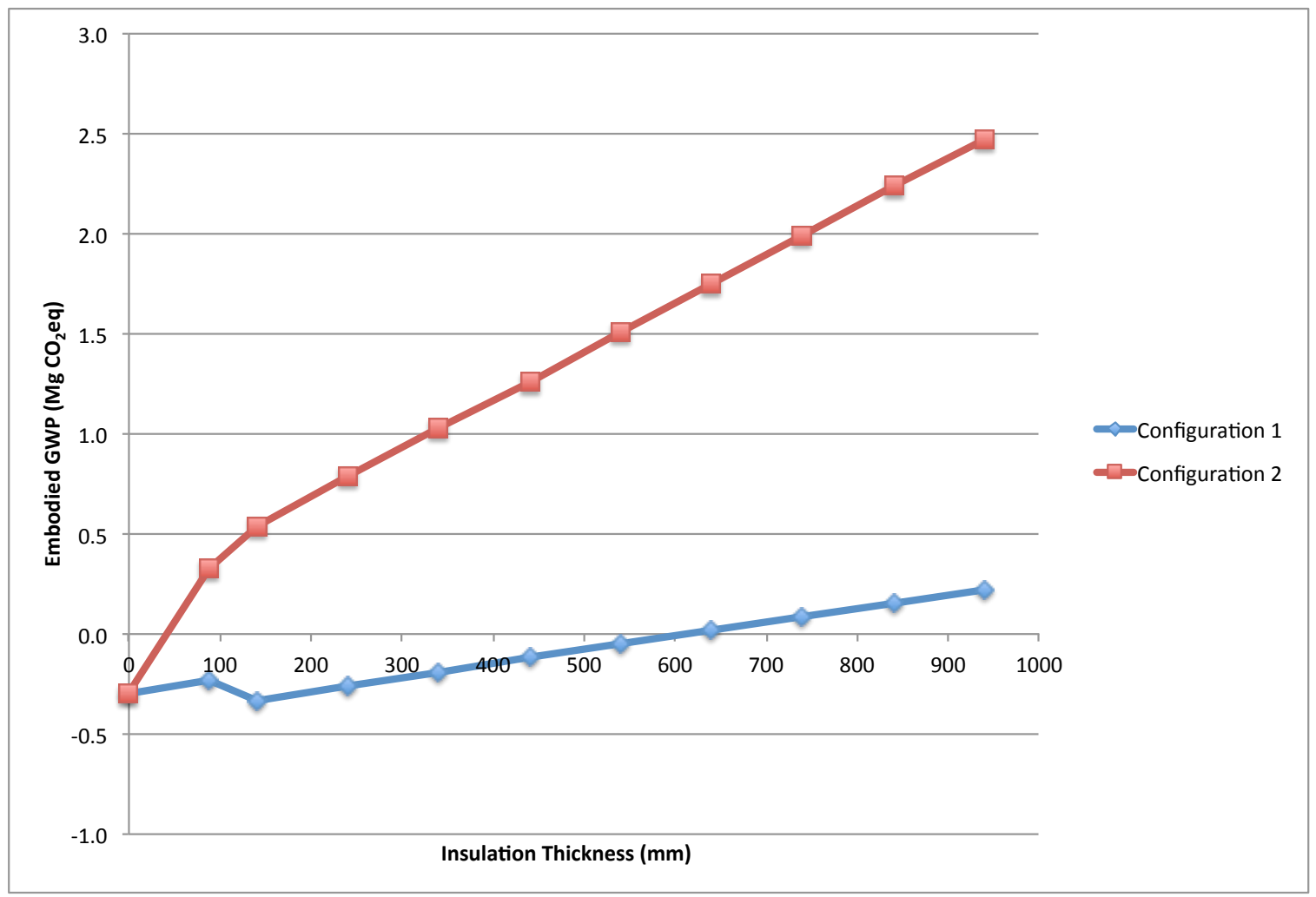

Figure 5-9 Comparison of Edmonton Roof Assembly Insulation Type Embodied GWP

Slab assembly embodied GWP was assessed for both EPS and XPS insulation materials. No change additional parameters were assessed. Embodied GWP results for both slab assembly insulation materials yielded positive values for all insulation thicknesses, indicating a release of carbon into the atmosphere over the assembly's 60-year lifespan (Figure 5-10, Figure 5-11 and Figure 5-12). An increasing trend in embodied GWP is evident as insulation levels are increased.

Wall cladding material selection has a greater impact on embodied GWP than insulation material type in both Toronto and Montreal, while wall cladding material has the greatest impact on GWP in Edmonton until an insulation thickness of approximately $500 \mathrm{~mm}$. Beyond this point, insulation choice has a greater impact on embodied GWP.

An assessment of the modeling results indicates that EPS has a lower GWP impact than XPS at all insulation thicknesses, with the difference in GWP between the two insulation materials progressively increasing as insulation thickness is 
increased. Slab assembly iterations assessed for both EPS and XPS have the lowest embodied GWP in Montreal, followed by Toronto, then Edmonton. For all of the cases evaluated, the embodied GWP impact of the concrete slab (denoted by data points for an insulation thickness of $0 \mathrm{~mm}$ ) is greater than the impact of insulation.

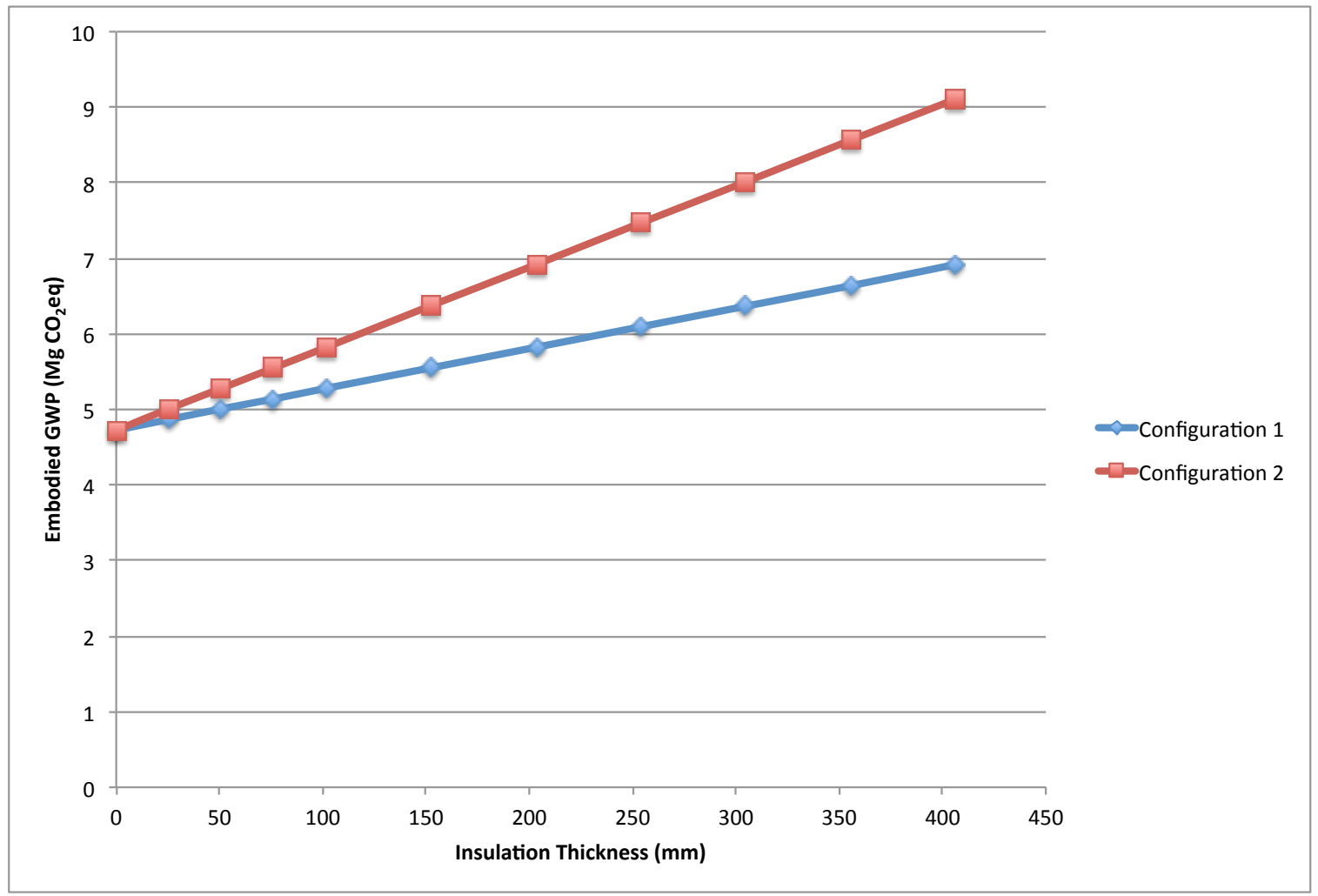

Figure 5-10 Comparison of Toronto Slab Assembly Insulation Type Embodied GWP 


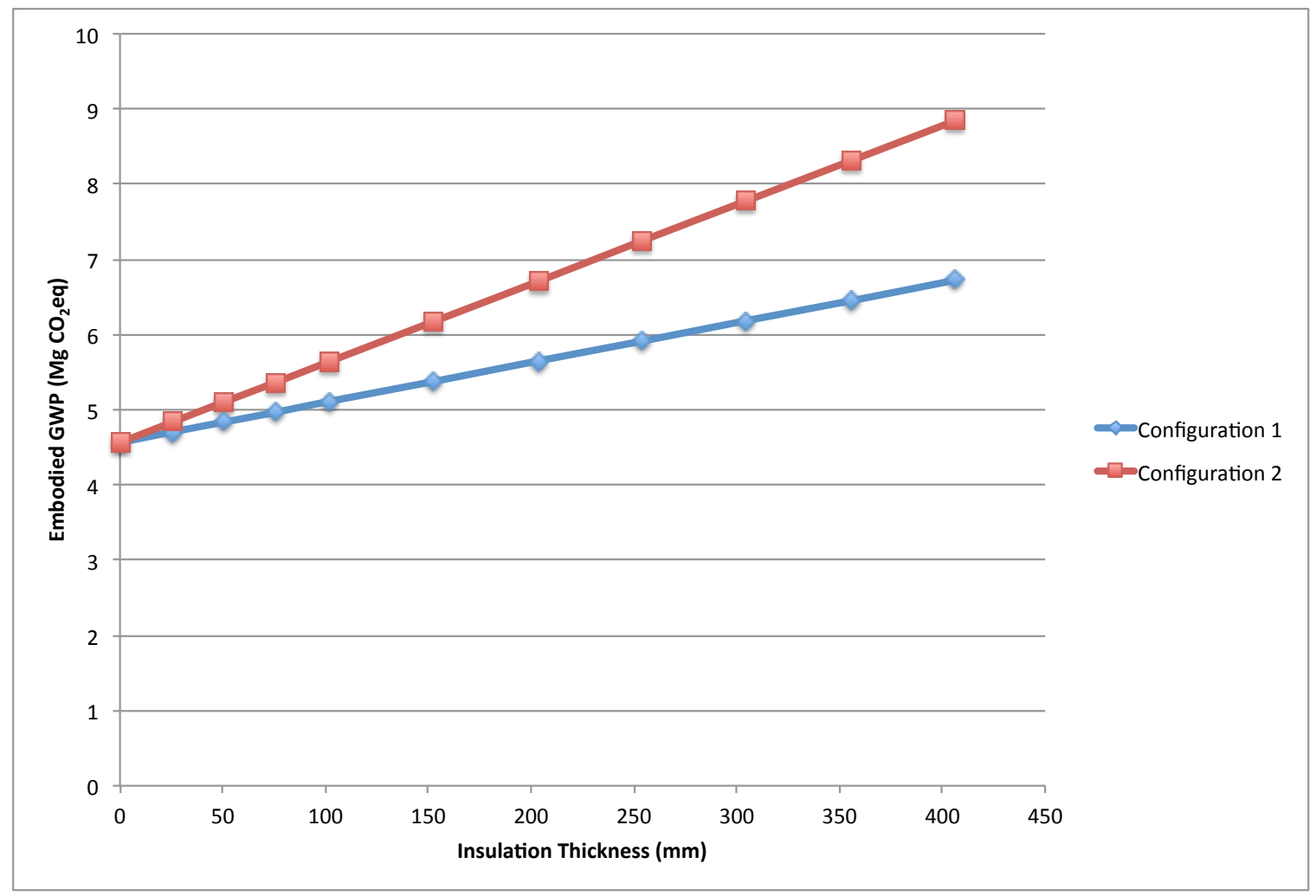

Figure 5-11 Comparison of Montreal Slab Assembly Insulation Type Embodied GWP

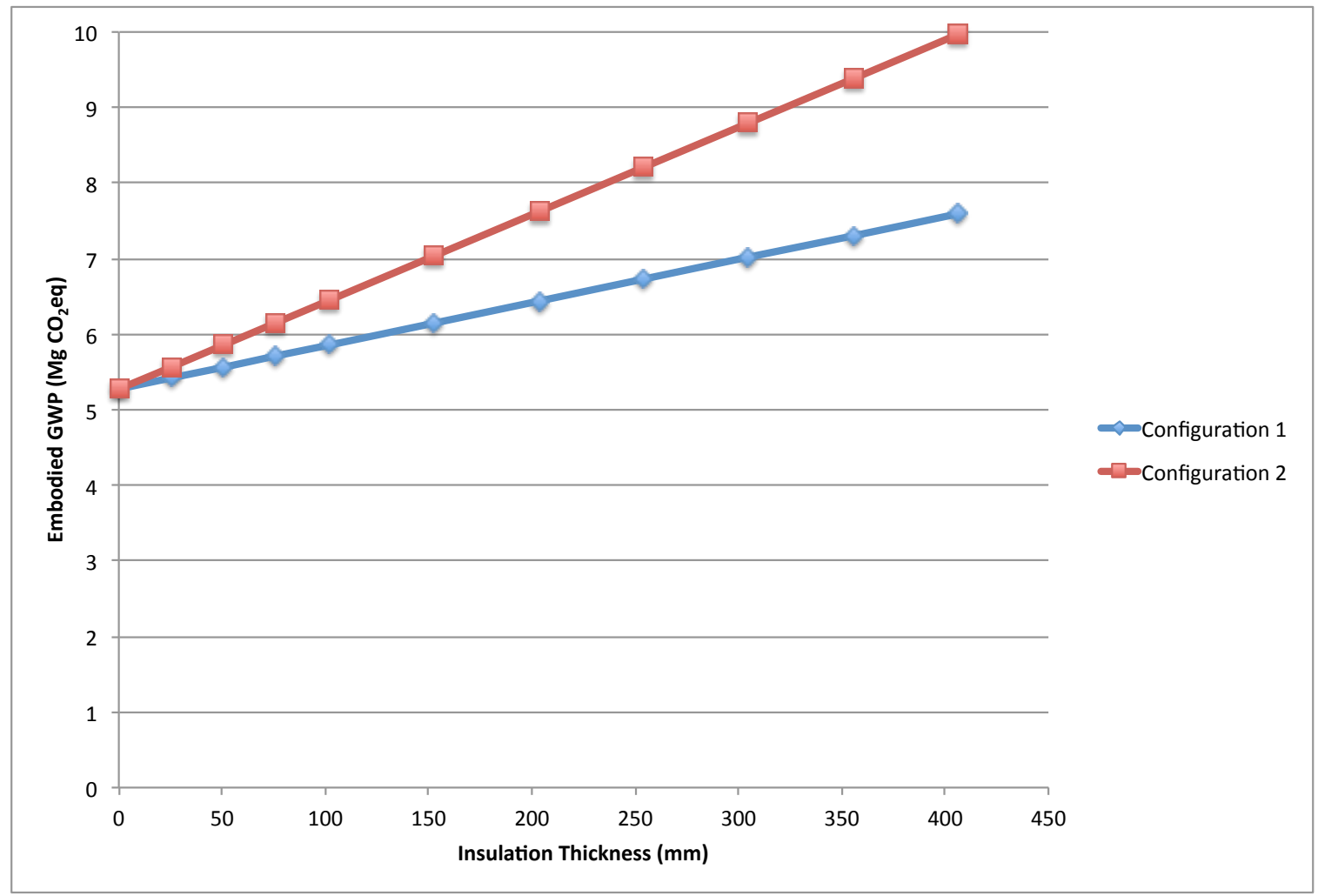

Figure 5-12 Comparison of Edmonton Slab Assembly Type Embodied GWP 
Montreal had the lowest embodied GWP for all assembly insulation and cladding configurations assessed, while Edmonton had the highest embodied GWP. Materials traditionally known to result in a higher envelope embodied GWP were confirmed to do so for all cases assessed except for the roof assembly in Montreal. Significant increases in embodied GWP were seen in all locations when changing slab assembly insulation from EPS to XPS, however, the impact of concrete in the slab assembly was larger than the impact of both EPS and XPS for all insulation thicknesses assessed. This indicates that limiting the use of concrete would yield a much greater impact on embodied GWP than selecting a low carbon insulation material.

When designing low carbon buildings, insulation and cladding materials should be selected based on the amount of energy required to manufacture them. Although this research did not consider the relative impact of different structural materials, the difference in impact found between the roof and wall assemblies, which consisted of dimensional lumber, and the slab assembly, comprised of concrete, indicates that the structure can have a significant impact on the total embodied carbon of the envelope. Therefore, further investigation into different assembly structural materials is required.

\subsubsection{Impact of Insulation Thickness on Building Life Cycle Global Warming Potential}

Results from the calculation of relative envelope life cycle GWP were plotted against assembly insulation thickness for Case A (NG) and Case B (Electric). All values reported in the following figures are relative to the respective reference building assemblies, which are plotted on the $\mathrm{x}$-axis for $\mathrm{y}=0$. Data points for assemblies with no insulation were excluded from the figures, since they were all one order of magnitude larger than other data points and would have made it difficult to discern trends in the data.

When examining the relative life cycle GWP of the wall assemblies in Figure $5-13$, the largest reductions occur when increasing insulation from $140 \mathrm{~mm}$ to 229 $\mathrm{mm}$. This represents the addition of an $89 \mathrm{~mm}$ exterior wall to single $140 \mathrm{~mm}$ 
structural stud wall. Changing the exterior wall to $140 \mathrm{~mm}$ for a total insulation depth of $280 \mathrm{~mm}$ achieves only a modest reduction. However, changing the external wall to a $240 \mathrm{~mm}$ (9.5 inch) deep I-joist configuration results in a second significant decrease in life cycle GWP. Additional increases in I-joist depth beyond $240 \mathrm{~mm}$, successively produce smaller reductions in GWP. Results for Toronto and Montreal follow identical trends, whereas the wall assemblies modeled for Edmonton yield greater reductions than the same assemblies modeled for the other two locations. The effect of diminishing returns in carbon reductions with increasing insulation thickness is evident, with reductions in emissions tapering significantly as insulation is increased beyond the reference building envelope level.

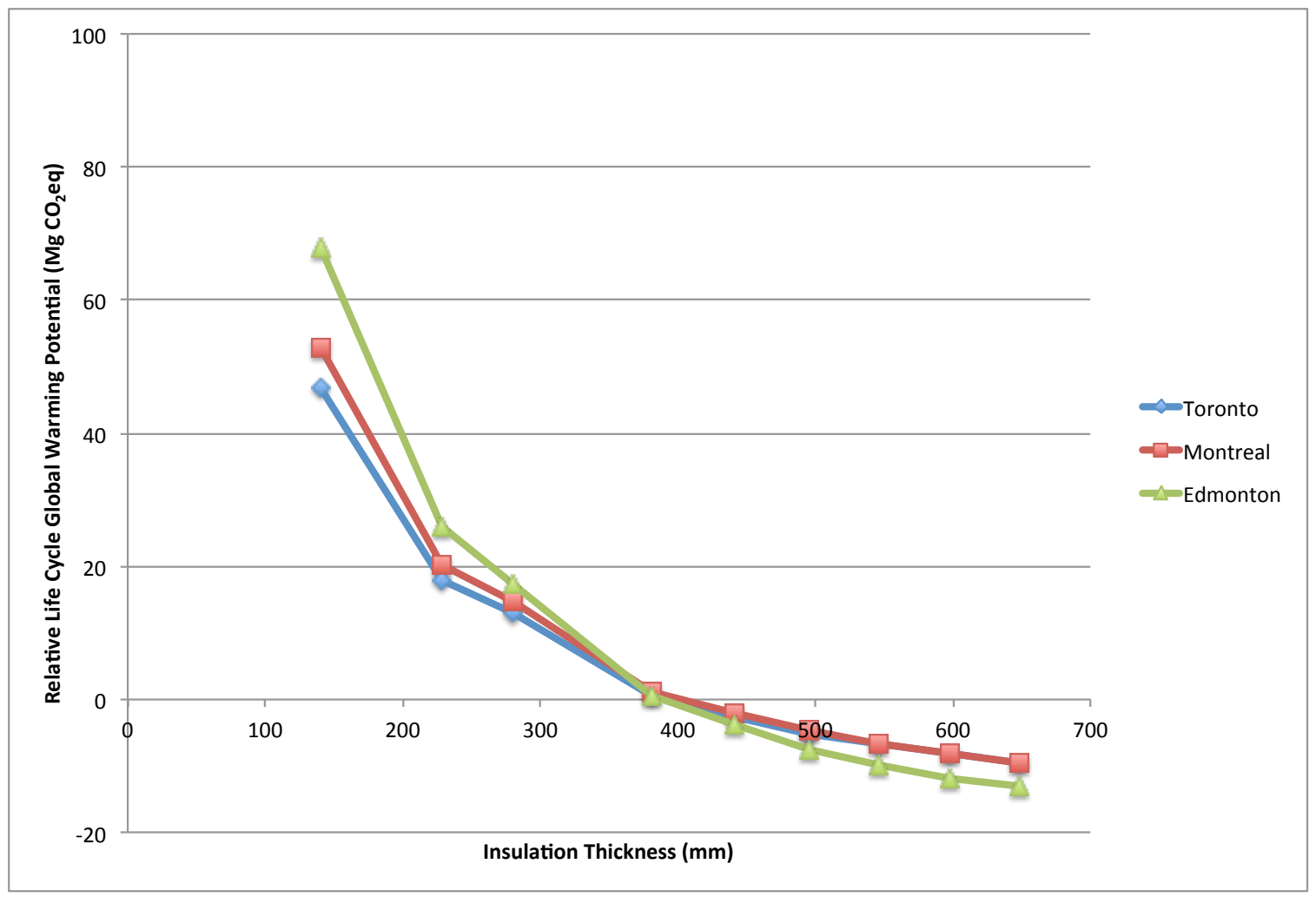

Figure 5-13 Case A (NG): Impact of Wall Insulation Thickness on Life Cycle GWP

For the roof assembly iterations in Figure 5-14, the largest reductions in life cycle GWP occur with the first increase in insulation thickness. The first two data points represent a change in ceiling service cavity depth from $89 \mathrm{~mm}$ to $140 \mathrm{~mm}$. Beyond an insulation thickness of approximately $550 \mathrm{~mm}$, very little additional 
reduction in life cycle GWP occurs for all locations. Once again, Edmonton has slightly larger relative reductions compared to the other two locations. GWP reductions are severely limited for insulation increments beyond the reference building envelope. The effect is more pronounced than for wall assembly insulation. The underlying reason behind the discrepancy between the wall and roof assemblies is due to the greater damping effect on embodied GWP due to the wall assembly structure, as previously identified in the embodied GWP analysis (Section 5.2.1).

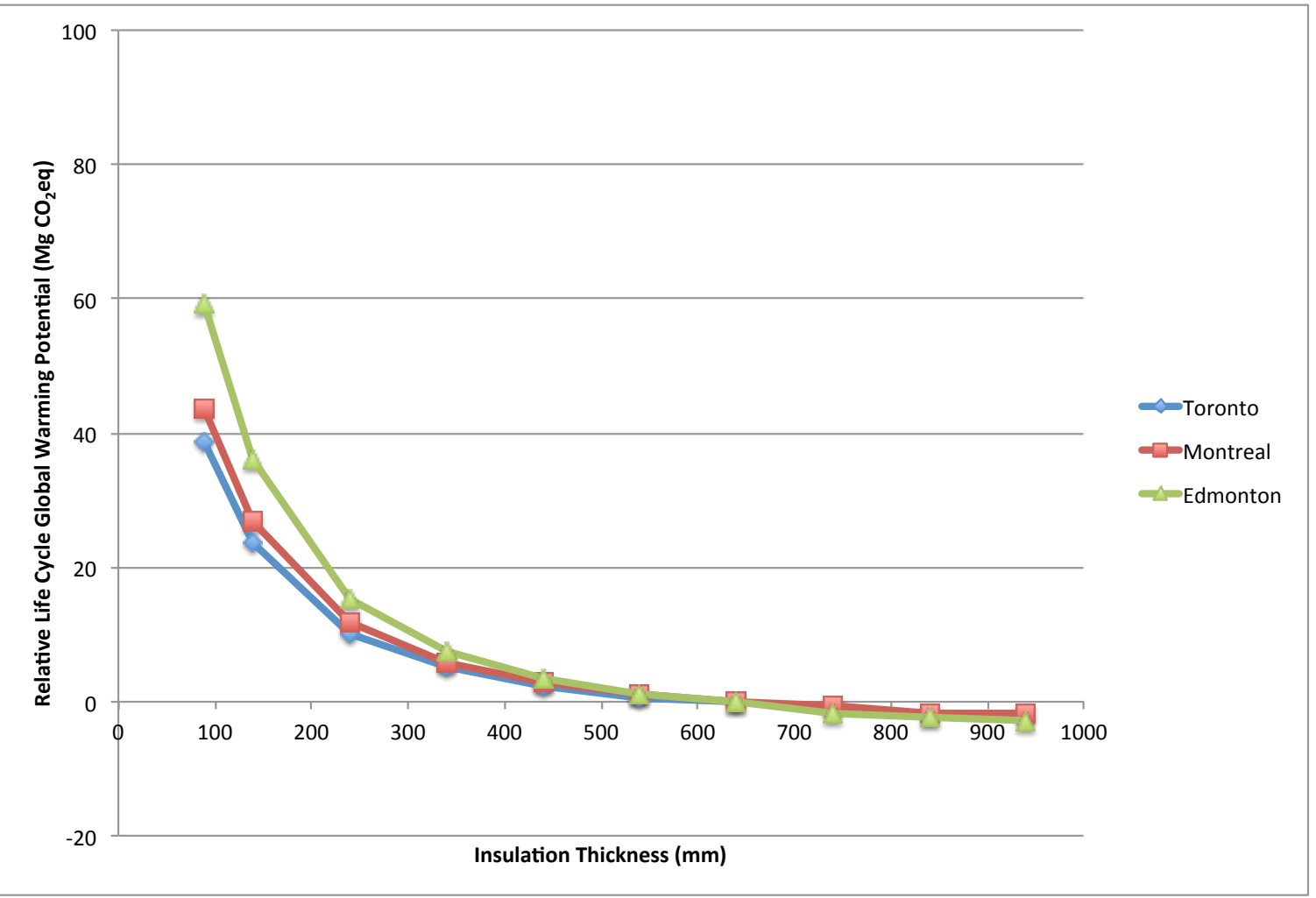

Figure 5-14 Case A (NG): Impact of Roof Insulation Thickness on Life Cycle GWP

Case A (NG) slab assembly results in Figure 5-15 follow a very similar trend to the roof assembly iterations, with the impact of diminishing returns indicated by the nearly flat slope towards the higher end of insulation thickness. Once again, Edmonton slab assembly iterations produced moderately larger reductions in GWP than for Montreal and Toronto. For all locations, very little reduction in life cycle GWP was attained when moving beyond $200 \mathrm{~mm}$ of insulation beneath the slab. 
Therefore, once the slab insulation reaches approximately $200 \mathrm{~mm}$, attention should shift to increasing the insulation thickness of the wall or roof assemblies.

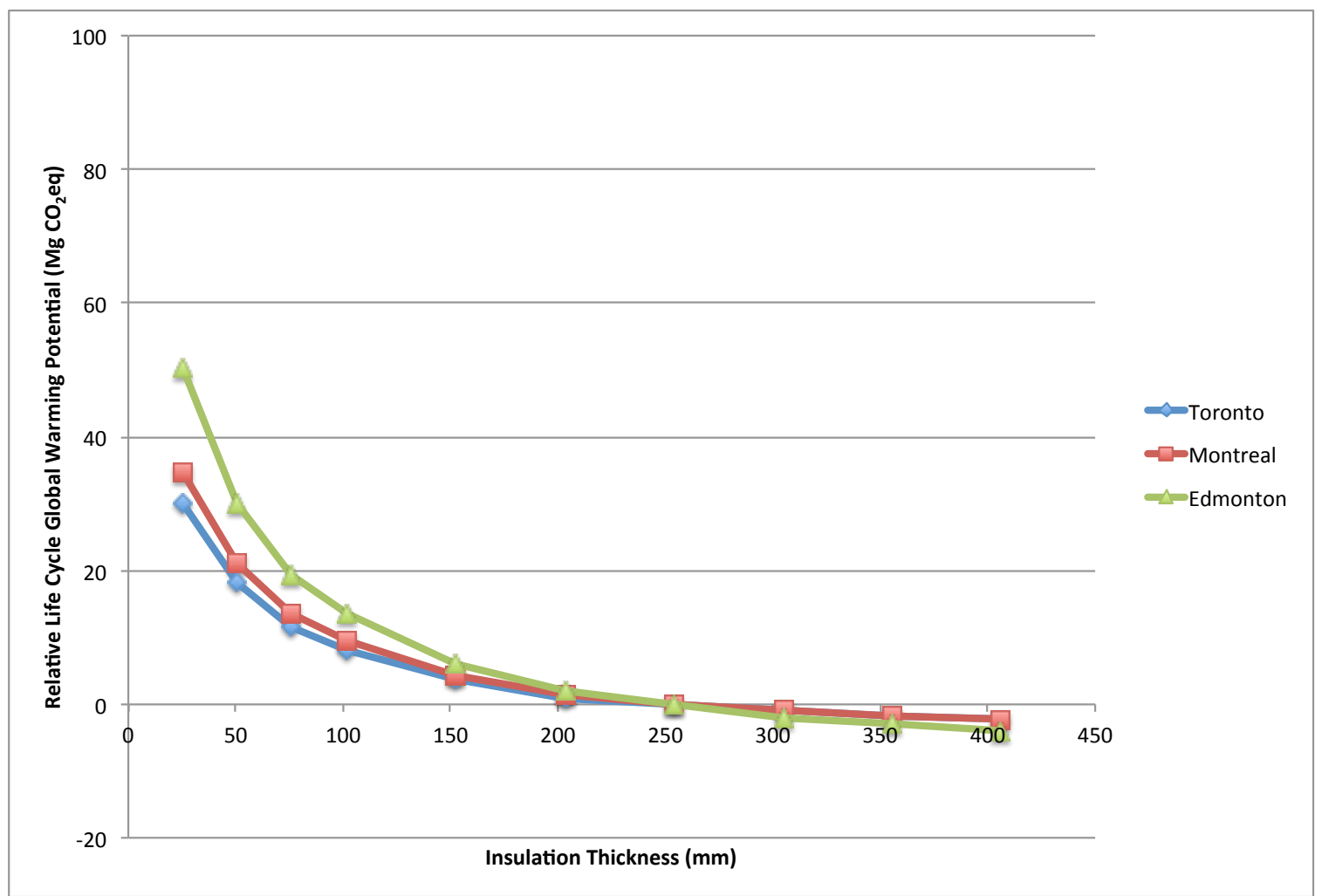

Figure 5-15 Case A (NG): Impact of Slab Insulation Thickness on Life Cycle GWP

These results indicate that when using natural gas mechanicals, the amount of GWP associated with heat loss through the slab assembly become insignificant relative to the additional embodied GWP from increasing the insulation thickness. This is true for all locations independent of climate, which is significant, since designing to meet an energy intensity target, such as the Passive House Standard annual heat demand, without considering GWP would result in insulating the slab beyond the point where significant carbon reductions are realized.

Case B (Electric) represents the use of electricity for space conditioning and domestic hot water production. Results of iterative modeling for the wall assembly (Figure 5-16), indicate that Edmonton has the largest opportunity for reductions in GWP beyond the reference building assembly insulation level. Comparatively smaller reductions are possible for Toronto, while increasing insulation beyond the 
reference building assembly level yields no significant reductions to life cycle GWP in Montreal. Figure 5-16 was re-plotted in Figure 5-17 without data for Edmonton to identify trends in the Toronto and Montreal data. Trend lines for both Toronto and Montreal indicate that the insulation level for the respective reference building walls are nearly ideal, since increasing the insulation beyond this point would yield minimal carbon reductions, while decreasing the insulation to the next lowest increment would significantly increase the impact on life cycle carbon. Interestingly, this point is where the exterior insulation cavity changes from a double-stud to a manufactured I-joist configuration. The I-joist is able to hold more insulation while reducing thermal bridging due to the thin cross-sectional profile of the I-joist OSB web. Subsequent increases in insulation cavity depth are accomplished by increasing the web depth of the I-joist. This allows for more insulation but does not significantly contribute to increasing the quantity of wood in the structure, thus reducing the carbon sequestering benefit of the structure relative to the impact of the insulation. 


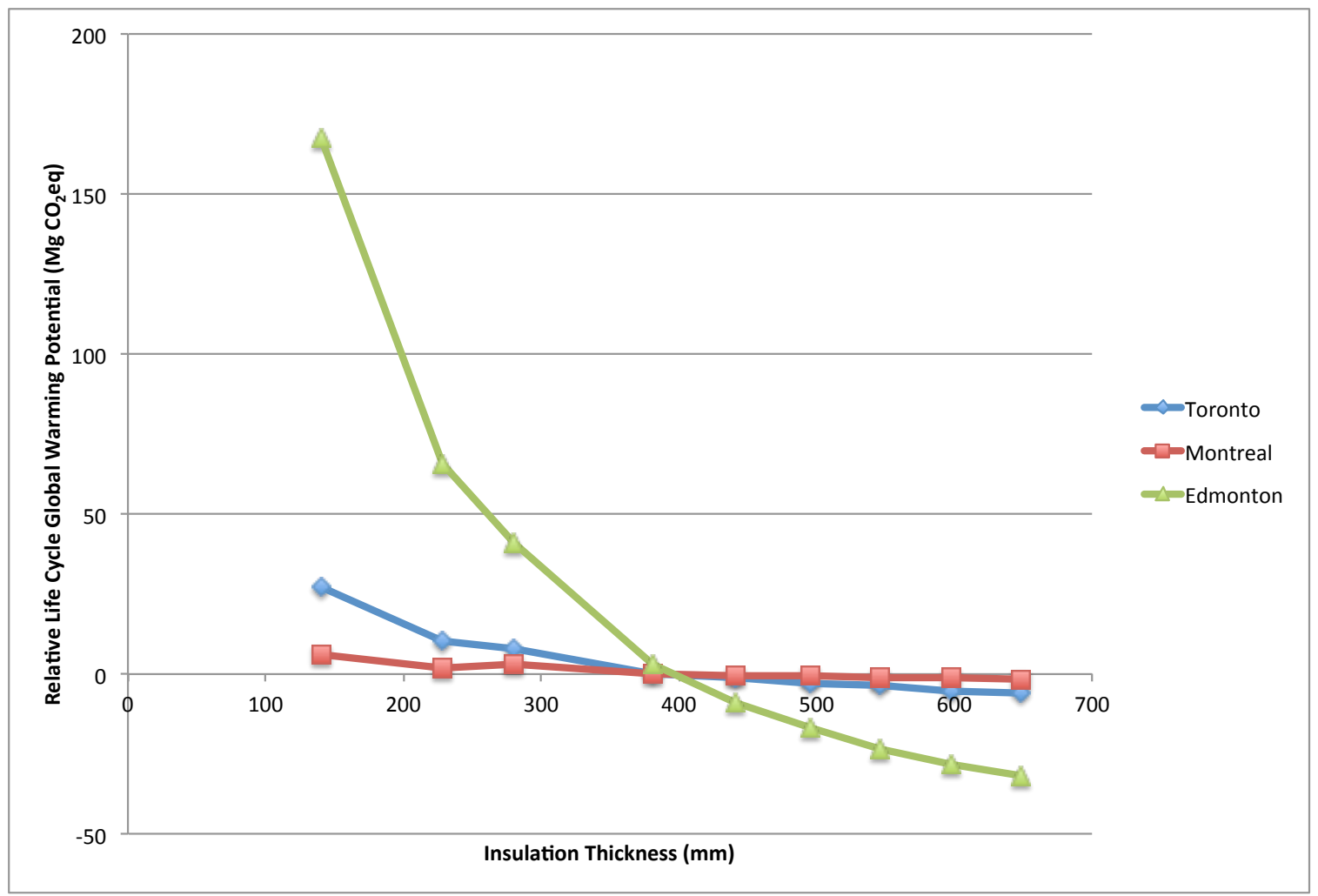

Figure 5-16 Case B (Electric): Impact of Wall Insulation Thickness on Life Cycle GWP

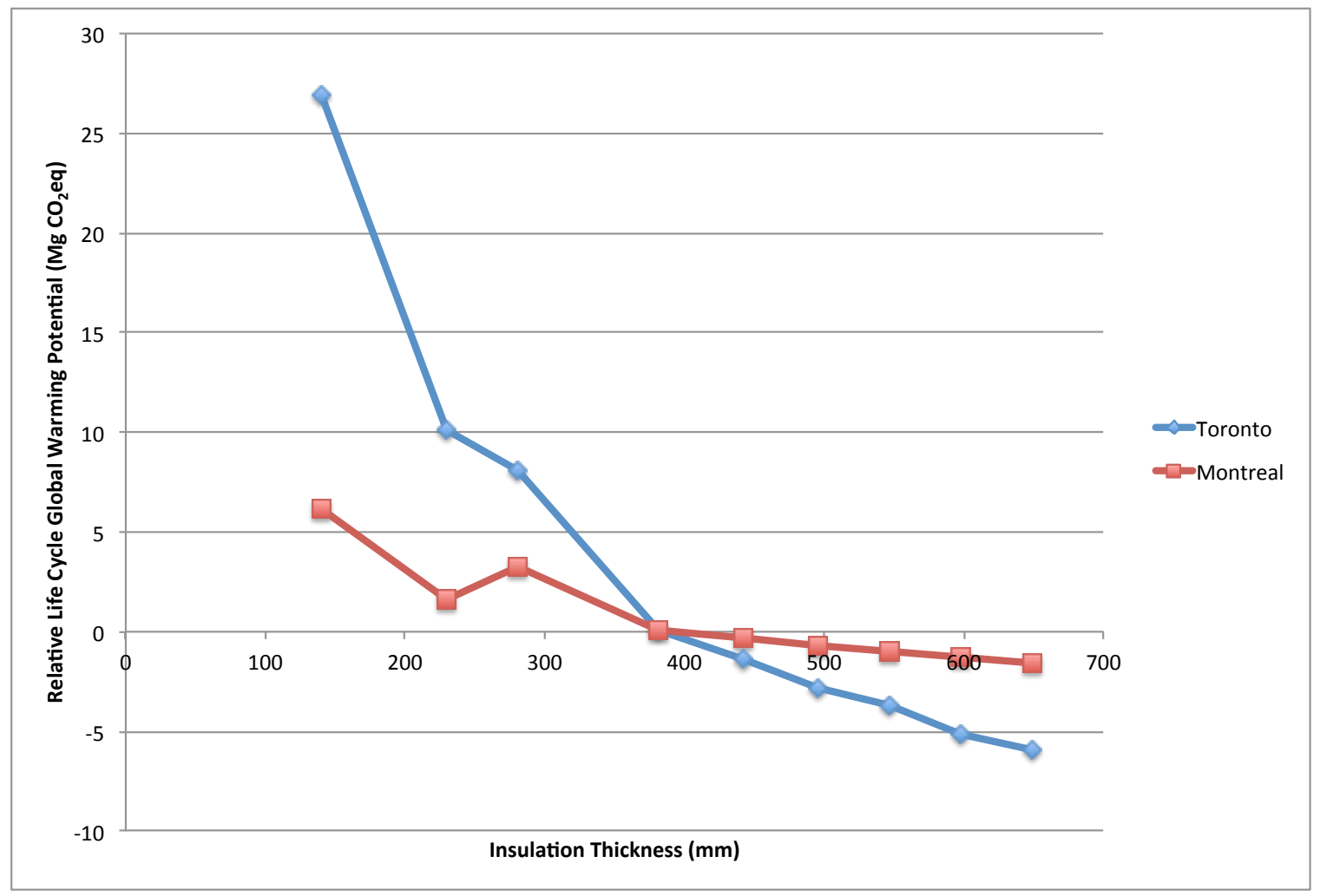

Figure 5-17 Case B (Electric): Impact of Wall Insulation on Life Cycle GWP (TO and MTL Only) 
Results for the roof assembly in Figure 5-18 indicate that Edmonton exhibits the highest reductions in GWP with increasing insulation thickness. Toronto has only modest reductions, while insulation thickness has almost now impact on life cycle GWP in Montreal. Data for Toronto and Montreal was re-plotted in Figure 5-19 to better discern any trends present. Closer analysis of Toronto reveals that insulating the roof beyond the reference building level does little to reduce life cycle GWP. In fact, the insulation level could be decreased to $440 \mathrm{~mm}$ without significantly increasing the impact. Increasing the insulation of the roof assembly beyond $240 \mathrm{~mm}$ in Montreal has a negligible impact on life cycle GWP. 


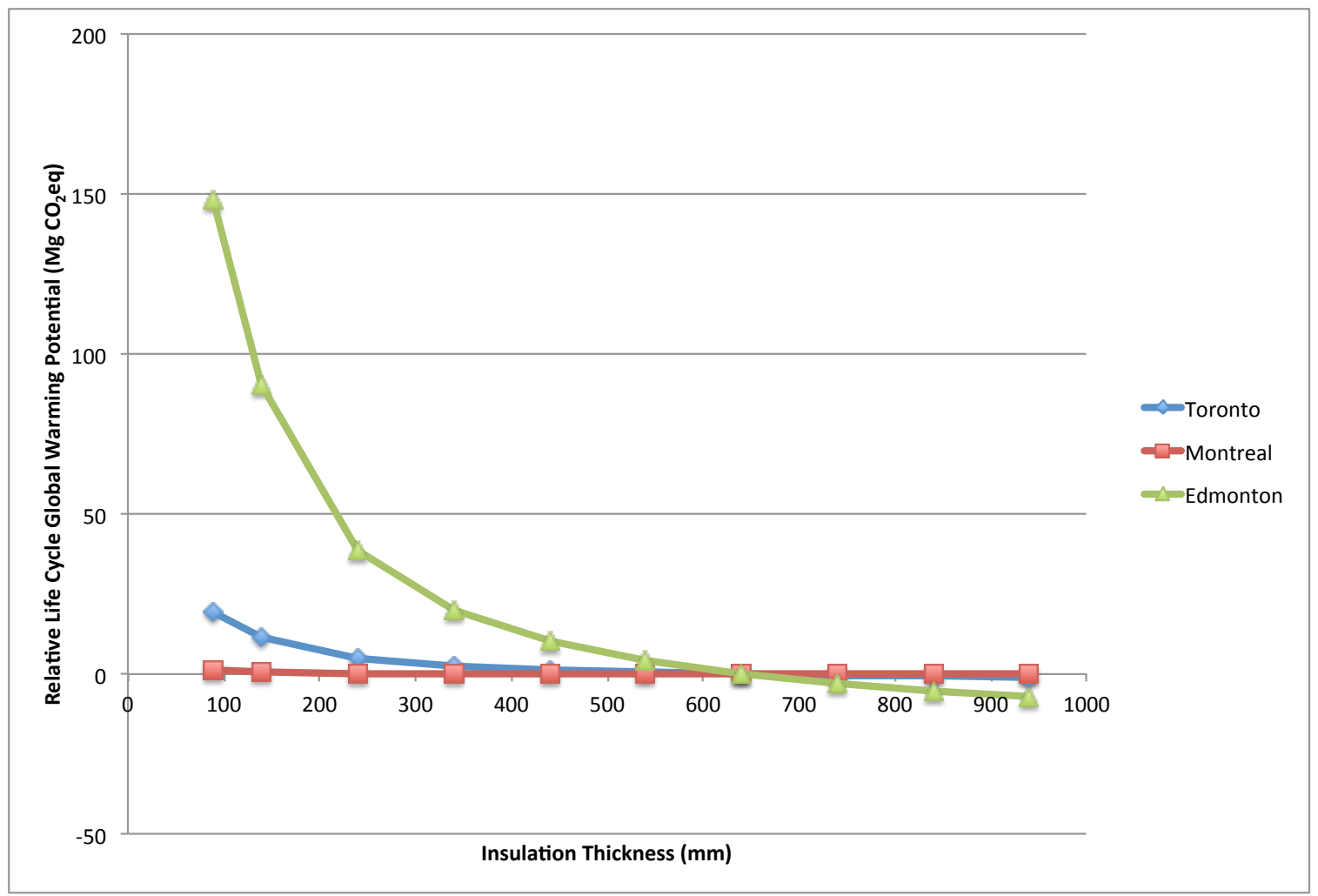

Figure 5-18 Case B (Electric): Impact of Roof Insulation Thickness on Life Cycle GWP

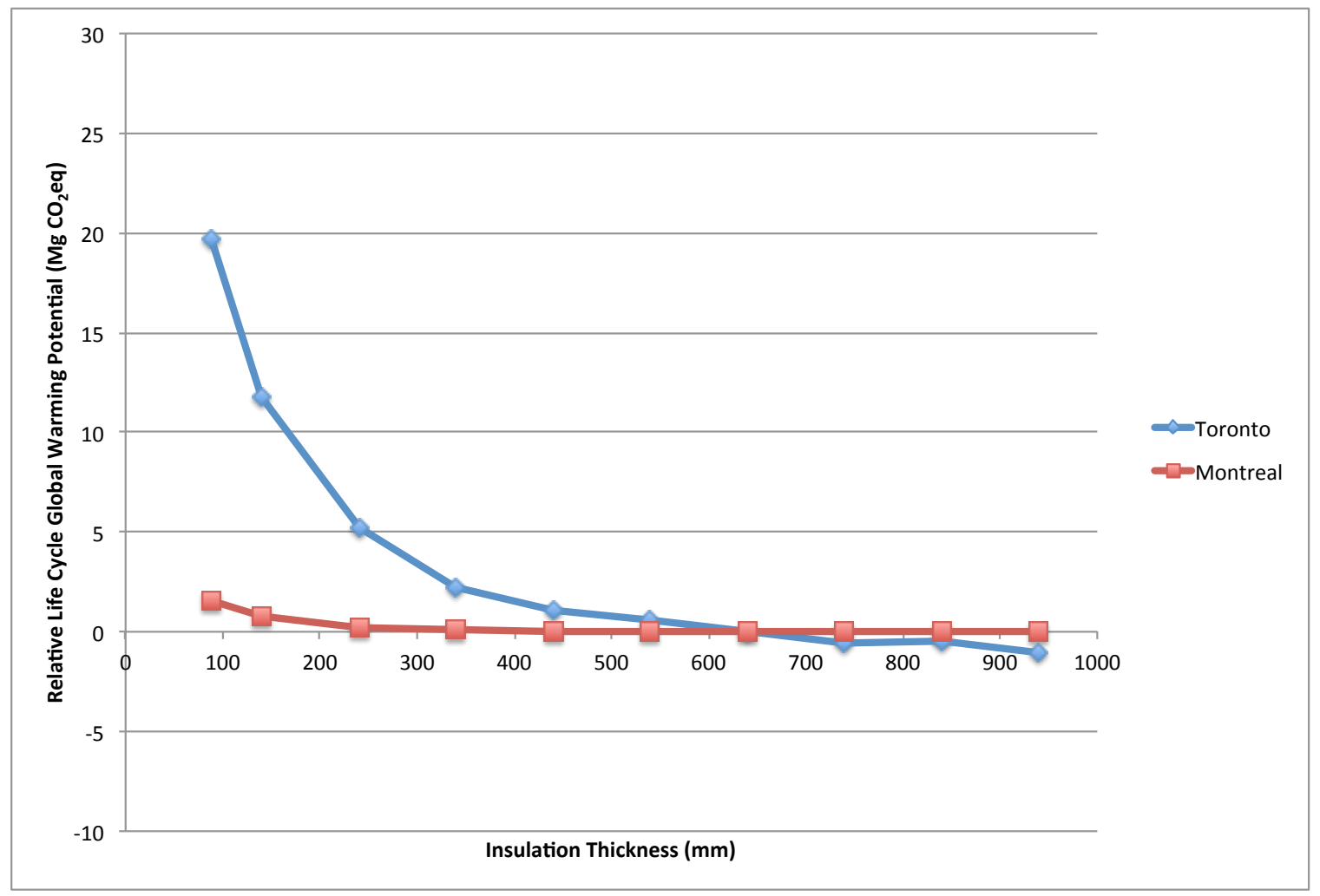

Figure 5-19 Case B (Electric) Impact of Roof Insulation on Life Cycle GWP (TO and MTL Only) 
Slab assembly results in Figure 5-20 again indicated that Edmonton exhibits the highest reductions in GWP with increasing insulation thickness. These results were also re-plotted for only Montreal and Toronto data to better discern trends (Figure 5-21). Reductions in life cycle GWP for Toronto seriously diminish for insulation increases beyond $200 \mathrm{~mm}$. Reductions in life cycle GWP are not feasible beyond the reference building level $(254 \mathrm{~mm})$, since an inflection point is reached at $350 \mathrm{~mm}$, after which the impact on life cycle carbon is increased. For Montreal, this inflection point occurs even earlier, between 100 and $150 \mathrm{~mm}$ of insulation, indicating the decreasing the insulation from reference building levels would yield a net decrease in life cycle GWP. 


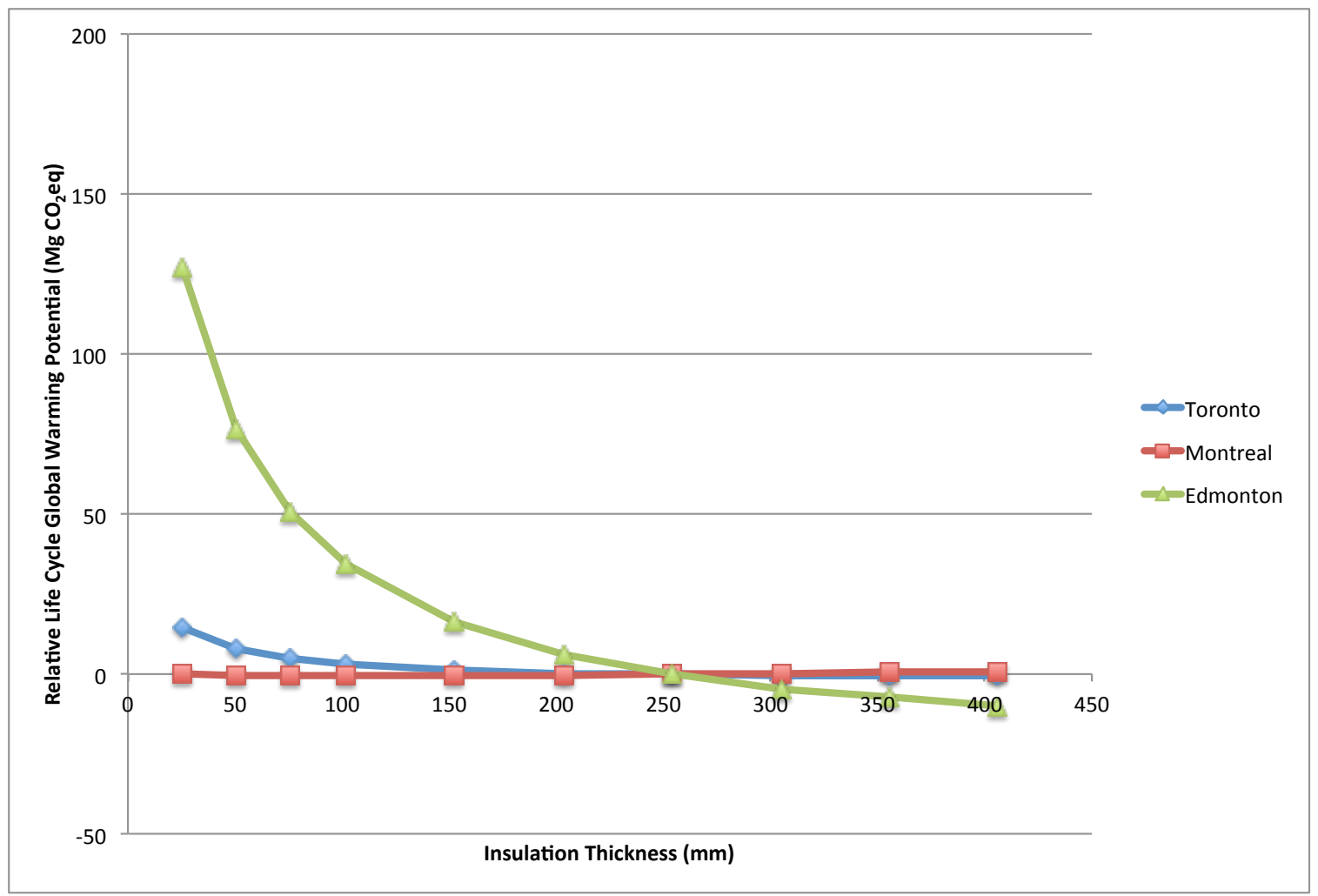

Figure 5-20 Case B (Electric): Impact of Slab Insulation Thickness on Life Cycle GWP

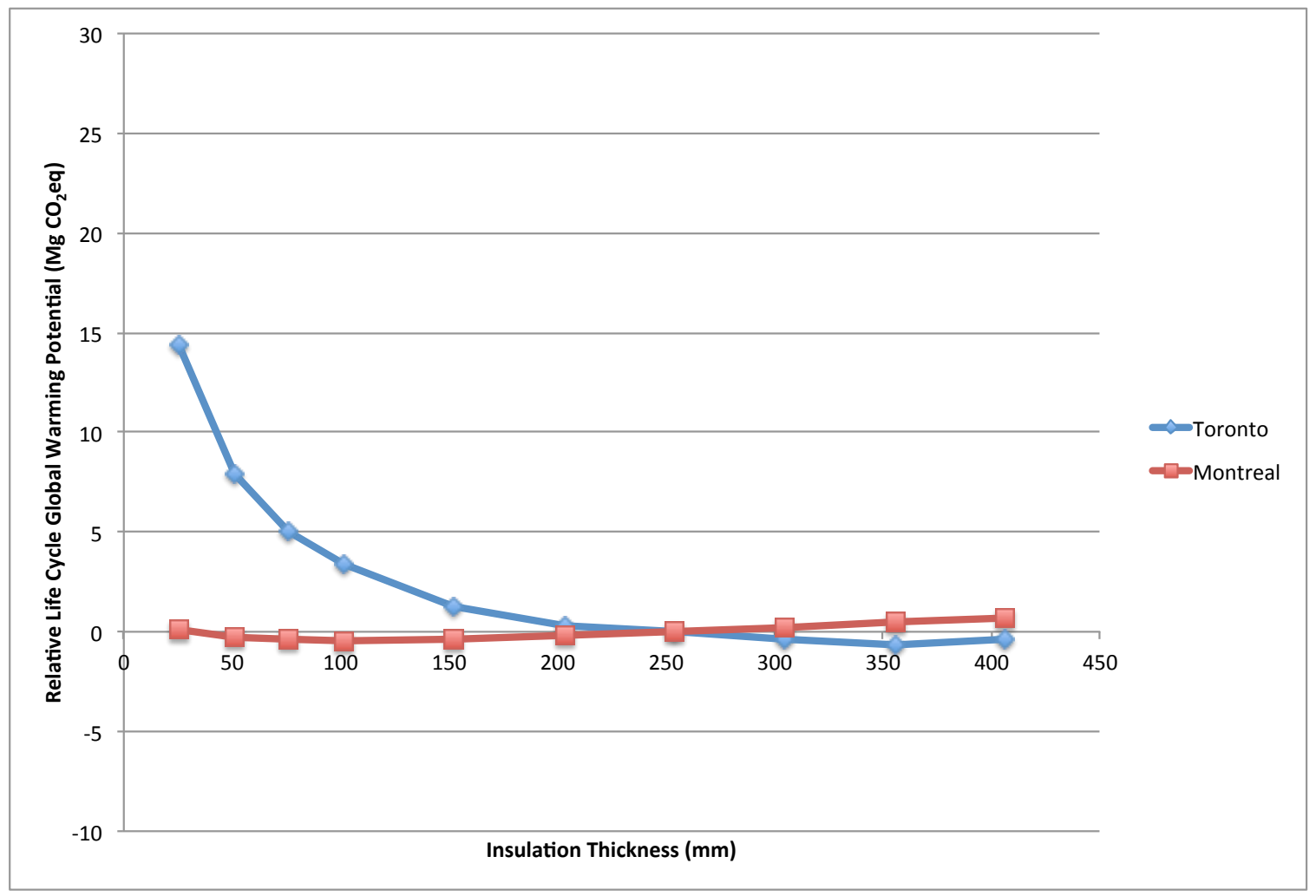

Figure 5-21 Case B (Electric): Impact of Slab Insulation on Life Cycle GWP (TO and MTL Only) 
All assemblies for both Case A (NG) and Case B (Electric) mechanical systems show evidence of diminishing returns, which progressively diminishes the impact that adding insulation has on the reducing the GWP of the assembly. The greatest opportunity for further reductions in life cycle GWP beyond the reference building exist for the wall assembly in Edmonton. Relatively small reductions can be realized for Toronto, while no significant potential for reductions exist for Montreal. This trend holds true for both roof and slab assemblies, although the reductions in life cycle GWP to be had are less than the reductions available for wall assemblies.

Both Case A (NG) and Case B (Electric) results indicate that wall assemblies offer the largest opportunity for decreasing life cycle GWP, while slab assemblies offer the smallest savings. This is in part due to the relative surface areas of the assemblies. Since walls make up a proportionately larger fraction of surface area than the roof and slab assemblies, the amount of heat transferred through the wall assembly will also be larger. Additionally, although the slab and roof assemblies have very similar surface areas, the slab assembly is in direct contact with the ground. The buffering impact of the soil results in a lower temperature differential between the interior and exterior surfaces of the slab assembly, thereby reducing heat transfer.

As previously determined in Section 5.1 .2 (p. 62), the impact of the low electricity carbon intensity in Montreal outweighs the increased heating requirements when examining operating GWP. Additionally, Case B (Electric) building assemblies modeled for Edmonton yield significantly larger reductions in GWP with increasing insulation than the same assemblies modeled for Montreal or Toronto. This is due to Edmonton being located in an electrical distribution region with high carbon intensity.

It should be noted that results of this analysis are limited to the specific building geometry investigated. Changes to building geometry would result in changes to the proportion of overall heat transfer of each assembly, consequently altering the impact that each assembly has on the total building life cycle GWP. Therefore, further research into the sensitivity of life cycle GWP to building geometry is warranted. 


\subsection{Envelope Life Cycle Optimization Results}

\subsubsection{Selection of Envelope Scenarios Based on Life Cycle GWP}

Results are presented in Table 5-12 through 5-19 indicate that, for all assemblies, diminishing reductions in assembly life cycle GWP occur when insulation thickness is increased. Each assembly was evaluated against the $-50 \mathrm{~kg} \mathrm{CO}{ }_{2} \mathrm{eq} / \mathrm{mm}$ threshold or the alternative criterion if this threshold was not reached, as described in Section 4.7.1 (p. 48). Three data points were selected, as denoted by bold font. The threshold value was not reached in the initial data set generated for Edmonton's wall assemblies in Case B (Electric), therefore the data set was increased by two insulation increments and re-evaluated. Although the threshold value was not reached when the additional increments were evaluated, the results were the same for two consecutive insulation levels, meeting the alternative selection criterion (Table 5-15). There was a decrease in the last data point over the previous one, however trends in the data for the same assembly located in Toronto and Montreal indicate that the results begin to oscillate around a point, without changing significantly with additional insulation increments. The alternative selection criterion was also met for Edmonton's Case B slab assembly (Table 5-17). A data point was discovered for Montreal Case B (Electric) wall (Table 5-16) that did not fit the expected trend in that a large increase in GWP occurred when wall insulation was increased from $229 \mathrm{~mm}$ to $280 \mathrm{~mm}$, whereas a decrease in GWP was seen for the other two locations. Therefore an additional scenario was created to capture the impact that this data point has. 
Table 5-12 Case A (NG): Calculated Change in Envelope Life Cycle Global Warming Potential with Increasing Wall Insulation Thickness

\begin{tabular}{|c|c|c|c|c|}
\hline \multirow[b]{2}{*}{$\begin{array}{l}\text { Insulation } \\
\text { Level }\end{array}$} & \multirow{2}{*}{$\begin{array}{l}\text { Insulation } \\
\text { Thickness } \\
(\mathrm{mm})\end{array}$} & \multicolumn{3}{|c|}{ Change in Wall Assembly LC GWP Indicator } \\
\hline & & $\begin{array}{l}\text { Toronto } \\
\left(\mathrm{kg} \mathrm{CO}{ }_{2} \mathrm{eq} / \mathrm{mm}\right)\end{array}$ & $\begin{array}{l}\text { Montreal } \\
\left(\mathrm{kg} \mathrm{CO}{ }_{2} \mathrm{eq} / \mathrm{mm}\right)\end{array}$ & $\begin{array}{l}\text { Edmonton } \\
\left(\mathrm{kg} \mathrm{CO}{ }_{2} \mathrm{eq} / \mathrm{mm}\right)\end{array}$ \\
\hline 0 & 0 & - & - & - \\
\hline 1 & 140 & -2681.8 & -2960.5 & -4172.9 \\
\hline 2 & 229 & -323.6 & -368.1 & -471.9 \\
\hline 3 & 280 & -97.7 & -104.9 & -170.3 \\
\hline 4 & 381 & -120.9 & -133.3 & -165.1 \\
\hline 5 & 442 & -54.2 & -54.7 & -71.7 \\
\hline 6 & 496 & -48.9 & -49.3 & -68.8 \\
\hline 7 & 546 & -28.0 & -40.6 & -49.2 \\
\hline 8 & 597 & -28.2 & -28.4 & -37.6 \\
\hline 9 & 648 & -28.0 & -28.5 & -25.8 \\
\hline \multicolumn{5}{|l|}{ Note: } \\
\hline \multicolumn{5}{|c|}{$\begin{array}{l}\text { Values in bold denote assemblies selected to represent low, medium and } \\
\text { high scenarios for evaluation of whole building energy and envelope } \\
\text { carbon performance }\end{array}$} \\
\hline
\end{tabular}


Table 5-13 Case A (NG): Calculated Reduction in Global Warming Potential with Increasing Roof Insulation Thickness

\begin{tabular}{|c|c|c|c|c|}
\hline \multirow[b]{2}{*}{$\begin{array}{l}\text { Insulation } \\
\text { Level }\end{array}$} & \multirow{2}{*}{\begin{tabular}{|l} 
Insulation \\
Thickness \\
$(\mathrm{mm})$
\end{tabular}} & \multicolumn{3}{|c|}{ Change in Roof Assembly LC GWP Indicator } \\
\hline & & $\begin{array}{l}\text { Toronto } \\
\left(\mathrm{kg} \mathrm{CO}{ }_{2} \mathrm{eq} / \mathrm{mm}\right)\end{array}$ & $\begin{array}{l}\text { Montreal } \\
\left(\mathrm{kg} \mathrm{CO}_{2} \mathrm{eq} / \mathrm{mm}\right)\end{array}$ & $\begin{array}{l}\text { Edmonton } \\
\left(\mathrm{kg} \mathrm{CO}_{2} \mathrm{eq} / \mathrm{mm}\right)\end{array}$ \\
\hline 0 & & - & - & - \\
\hline 1 & 89 & -1718.5 & -1907.4 & -2668.9 \\
\hline 2 & 140 & -296.6 & -331.8 & -449.1 \\
\hline 3 & 240 & -137.3 & -149.6 & -209.2 \\
\hline 4 & 340 & -47.5 & -59.6 & -77.3 \\
\hline 5 & 440 & -29.5 & -29.6 & -41.3 \\
\hline 6 & 540 & -17.5 & -17.7 & -23.3 \\
\hline 7 & 640 & -5.5 & -11.6 & -11.3 \\
\hline 8 & 740 & -11.5 & -5.6 & -17.3 \\
\hline 9 & 840 & -5.5 & -11.6 & -5.3 \\
\hline 10 & 940 & -5.5 & 0.4 & -5.3 \\
\hline $\begin{array}{l}\text { Note: } \\
\text { Values in b } \\
\text { and high sc } \\
\text { carbon per }\end{array}$ & formance & $\begin{array}{l}\text { emblies selec } \\
\text { luation of wh }\end{array}$ & $\begin{array}{l}\text { d to represen } \\
\text { le building en }\end{array}$ & $\begin{array}{l}\text { low, medium } \\
\text { gy and envelope }\end{array}$ \\
\hline
\end{tabular}


Table 5-14 Case A (NG): Calculated Reduction in Global Warming Potential with Increasing Slab Insulation Thickness

\begin{tabular}{|c|c|c|c|c|}
\hline \multirow[b]{2}{*}{$\begin{array}{l}\text { Insulation } \\
\text { Level }\end{array}$} & \multirow{2}{*}{$\begin{array}{l}\text { Insulation } \\
\text { Thickness } \\
(\mathrm{mm})\end{array}$} & \multicolumn{3}{|c|}{ Change in Slab Assembly LC GWP Indicator } \\
\hline & & $\begin{array}{l}\text { Toronto } \\
\left(\mathrm{kg} \mathrm{CO} \mathrm{CO}_{2} \mathrm{eq} / \mathrm{mm}\right)\end{array}$ & $\begin{array}{l}\text { Montreal } \\
\left(\mathrm{kg} \mathrm{CO}{ }_{2} \mathrm{eq} / \mathrm{mm}\right)\end{array}$ & $\begin{array}{l}\text { Edmonton } \\
\left(\mathrm{kg} \mathrm{CO} \mathrm{CO}_{2} \mathrm{eq} / \mathrm{mm}\right)\end{array}$ \\
\hline 0 & 0 & - & - & - \\
\hline 1 & 25 & -1222.8 & -1388.1 & -1954.7 \\
\hline 2 & 51 & -466.9 & -538.1 & -797.6 \\
\hline 3 & 76 & -254.7 & -301.9 & -419.3 \\
\hline 4 & 102 & -136.2 & -159.8 & -230.7 \\
\hline 5 & 152 & -89.2 & -101.1 & -147.8 \\
\hline 6 & 203 & -53.7 & -53.7 & -76.9 \\
\hline 7 & 254 & -18.3 & -30.2 & -41.5 \\
\hline 8 & 305 & -18.3 & -18.3 & -41.5 \\
\hline 9 & 356 & -18.3 & -18.4 & -18.1 \\
\hline 10 & 406 & -6.3 & -6.4 & -17.9 \\
\hline \multicolumn{5}{|l|}{ Note: } \\
\hline \multicolumn{5}{|c|}{$\begin{array}{l}\text { Values in bold denote assemblies selected to represent low, medium } \\
\text { and high scenarios for evaluation of whole building energy and envelope } \\
\text { carbon performance }\end{array}$} \\
\hline
\end{tabular}


Table 5-15 Case B (Electric): Calculated Reduction in Global Warming Potential with Increasing Wall Insulation Thickness

\begin{tabular}{|c|c|c|c|c|}
\hline \multirow[b]{2}{*}{$\begin{array}{l}\text { Insulation } \\
\text { Level }\end{array}$} & \multirow{2}{*}{\begin{tabular}{|l|} 
Insulation \\
Thickness \\
(mm)
\end{tabular}} & \multicolumn{3}{|c|}{ Change in Wall Assembly LC GWP Indicator } \\
\hline & & $\begin{array}{l}\text { Toronto } \\
\left(\mathrm{kg} \mathrm{CO} \mathrm{C}_{2} \mathrm{eq} / \mathrm{mm}\right)\end{array}$ & $\begin{array}{l}\text { Montreal } \\
\left(\mathrm{kg} \mathrm{CO} \mathrm{C}_{2} \mathrm{eq} / \mathrm{mm}\right)\end{array}$ & $\begin{array}{l}\text { Edmonton } \\
\left(\mathrm{kg} \mathrm{CO}_{2} \mathrm{eq} / \mathrm{mm}\right)\end{array}$ \\
\hline 0 & 0 & - & 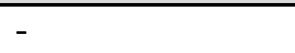 & 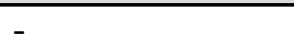 \\
\hline 1 & 140 & -1464.7 & -115.2 & -10537.2 \\
\hline 2 & 29 & -188.8 & -50.6 & -1146.1 \\
\hline 3 & 80 & -38.8 & 31.5 & -487.9 \\
\hline 4 & 381 & -79.5 & -31.0 & -372.4 \\
\hline 5 & 442 & -24.4 & -7.2 & -201.0 \\
\hline 6 & 496 & -26.7 & -6.5 & -146.6 \\
\hline 7 & 546 & -16.1 & -6.4 & -120.1 \\
\hline 8 & 1 & -28.1 & -5.8 & -96.7 \\
\hline 9 & 648 & -16.1 & -5.7 & -73.0 \\
\hline $10^{*}$ & 699 & - & - & -73.0 \\
\hline $11 *$ & 750 & & - & -61.0 \\
\hline \multicolumn{5}{|c|}{$\begin{array}{l}\text { Note: } \\
\text { Values in bold denote assemblies selected to represent low, medium and } \\
\text { high scenarios for evaluation of whole building energy and envelope } \\
\text { carbon performance } \\
\text { * indicates runs only conducted for Edmonton }\end{array}$} \\
\hline
\end{tabular}


Table 5-16 Case B (Electric): Calculated Reduction in Global Warming Potential with Increasing Roof Insulation Thickness

\begin{tabular}{|c|c|c|c|c|}
\hline \multirow[b]{2}{*}{$\begin{array}{l}\text { Insulation } \\
\text { Level }\end{array}$} & \multirow{2}{*}{\begin{tabular}{|l|} 
Insulation \\
Thickness \\
$(\mathrm{mm})$
\end{tabular}} & \multicolumn{3}{|c|}{ Change in Roof Assembly LC GWP Indicator } \\
\hline & & \begin{tabular}{|l|} 
Toronto \\
$\left(\mathrm{kg} \mathrm{CO}{ }_{2} \mathrm{eq} / \mathrm{mm}\right)$
\end{tabular} & $\begin{array}{l}\text { Montreal } \\
\left(\mathrm{kg} \mathrm{CO}{ }_{2} \mathrm{eq} / \mathrm{mm}\right)\end{array}$ & $\begin{array}{l}\text { Edmonton } \\
\left(\mathrm{kg} \mathrm{CO}_{2} \mathrm{eq} / \mathrm{mm}\right)\end{array}$ \\
\hline 0 & 0 & - & - & - \\
\hline 1 & 89 & -909.5 & -72.3 & -6653.1 \\
\hline 2 & 140 & -155.4 & -15.3 & -1131.5 \\
\hline 3 & 240 & -65.3 & -5.6 & -515.2 \\
\hline 4 & 340 & -29.5 & -1.4 & -185.3 \\
\hline 5 & 440 & -11.5 & -0.8 & -101.3 \\
\hline 6 & 540 & -5.5 & -0.3 & -59.3 \\
\hline 7 & 640 & -5.5 & 0.0 & -41.3 \\
\hline 8 & 740 & -5.5 & 0.1 & -29.3 \\
\hline 9 & 840 & 0.5 & 0.2 & -23.3 \\
\hline 10 & 940 & -5.5 & 0.2 & -17.3 \\
\hline \\
\hline \multicolumn{5}{|c|}{$\begin{array}{l}\text { Note: } \\
\text { Values in bold denote assemblies selected to represent low, medium and } \\
\text { high scenarios for evaluation of whole building energy and envelope } \\
\text { carbon performance }\end{array}$} \\
\hline
\end{tabular}


Table 5-17 Case B (Electric): Calculated Reduction in Global Warming Potential with Increasing Slab Insulation Thickness

\begin{tabular}{|c|c|c|c|c|}
\hline \multirow[b]{2}{*}{$\begin{array}{l}\text { Insulation } \\
\text { Level }\end{array}$} & \multirow{2}{*}{\begin{tabular}{|l|l|}
$\begin{array}{l}\text { Insulation } \\
\text { Thickness } \\
(\mathrm{mm})\end{array}$ \\
\cline { 1 - 1 }
\end{tabular}} & \multicolumn{3}{|c|}{ Change in Slab Assembly LC GWP Indicator } \\
\hline & & $\begin{array}{l}\text { Toronto } \\
\left(\mathrm{kg} \mathrm{CO} \mathrm{CO}_{2} \mathrm{eq} / \mathrm{mm}\right)\end{array}$ & $\begin{array}{l}\text { Montreal } \\
(\mathrm{kg} \mathrm{CO}=\mathrm{eq} / \mathrm{mm})\end{array}$ & $\begin{array}{l}\text { Edmonton } \\
\left(\mathrm{kg} \mathrm{CO} \mathrm{C}_{2} \mathrm{eq} / \mathrm{mm}\right)\end{array}$ \\
\hline 0 & 0 & - & - & - \\
\hline 1 & 25 & -703.1 & -51.1 & -4954.7 \\
\hline 2 & 51 & -254.3 & -13.7 & -1978.7 \\
\hline 3 & 76 & -113.0 & -6.6 & -1033.4 \\
\hline 4 & 102 & -65.3 & -1.5 & -632.2 \\
\hline 5 & 152 & -41.9 & 1.7 & -360.4 \\
\hline 6 & 203 & -18.3 & 3.0 & -195.0 \\
\hline 7 & 254 & -6.5 & 4.3 & -124.2 \\
\hline 8 & 305 & -6.5 & 4.4 & -88.8 \\
\hline 9 & 356 & -6.5 & 4.5 & -53.5 \\
\hline 10 & 406 & 5.6 & 4.9 & -53.3 \\
\hline \multicolumn{5}{|c|}{$\begin{array}{l}\text { Note: } \\
\text { Values in bold denote assemblies selected to represent low, medium and } \\
\text { high scenarios for evaluation of whole building energy and envelope } \\
\text { carbon performance }\end{array}$} \\
\hline
\end{tabular}

Scenarios for Case A (NG) and Case B (Electric) were selected along with the respective assembly insulation thicknesses are summarized in Table 5-18. A total of 19 scenarios were selected for further modeling as per the method described in Section 4.7.3 (p. 52). When compared to one another, the selected assembly configurations are similar for most permutations of location and mechanical system, with the exception of the assemblies chosen for Case B (Electric) in Montreal and Edmonton, which were found to have significantly lower and higher levels of insulation, respectively. 
Table 5-18 Summary of Assemblies Selected for Case A (NG) and Case B (Electric) Scenarios

\begin{tabular}{|l|l|crr|}
\hline & Insulation & \multicolumn{4}{|c|}{ Assembly Insulation Dimensions (mm) } \\
\cline { 2 - 5 } Scenario Name & Level & Roof & Walls & Slab \\
\hline Toronto & & \multicolumn{3}{c}{} \\
TO Scenario 1A & Low & 240 & 442 & 203 \\
TO Scenario 1B & Low & 240 & 381 & 102 \\
TO Scenario 2A & Medium & 340 & 496 & 254 \\
TO Scenario 2B & Medium & 340 & 442 & 152 \\
TO Scenario 3A & High & 440 & 546 & 305 \\
TO Scenario 3B & High & 440 & 496 & 203 \\
Montreal & & & & \\
MTL Scenario 1A & Low & 340 & 442 & 203 \\
MTL Scenario 1B & Low & 89 & 229 & 25 \\
MTL Scenario 2A & Medium & 440 & 496 & 254 \\
MTL Scenario 2B & Medium & 140 & 280 & 51 \\
MTL Scenario 3A & High & 540 & 546 & 305 \\
MTL Scenario 3B & High & 240 & 381 & 76 \\
MTL Scenario 4B & Extra & 340 & 442 & 102 \\
Edmonton & & & & \\
EDM Scenario 1A & Low & 340 & 496 & 203 \\
EDM Scenario 1B & Low & 540 & 648 & 305 \\
EDM Scenario 2A & Medium & 440 & 546 & 254 \\
EDM Scenario 2B & Medium & 640 & 699 & 356 \\
EDM Scenario 3A & High & 540 & 597 & 305 \\
EDM Scenario 3B & High & 740 & 750 & 406 \\
\hline
\end{tabular}

\subsubsection{Comparison of Envelope Scenario Annual Heat Demand and Life Cycle GWP}

Annual heat demand and life cycle GWP were compared for 31 scenarios to determine whether a correlation exists between the two variables.

Results summarized in Figure 5-22 for Case A (NG), show large differences in life cycle GWP between Passive House scenarios, with scenarios in Toronto and Edmonton having 70\% and 282\% greater emissions than Montreal, respectively. 


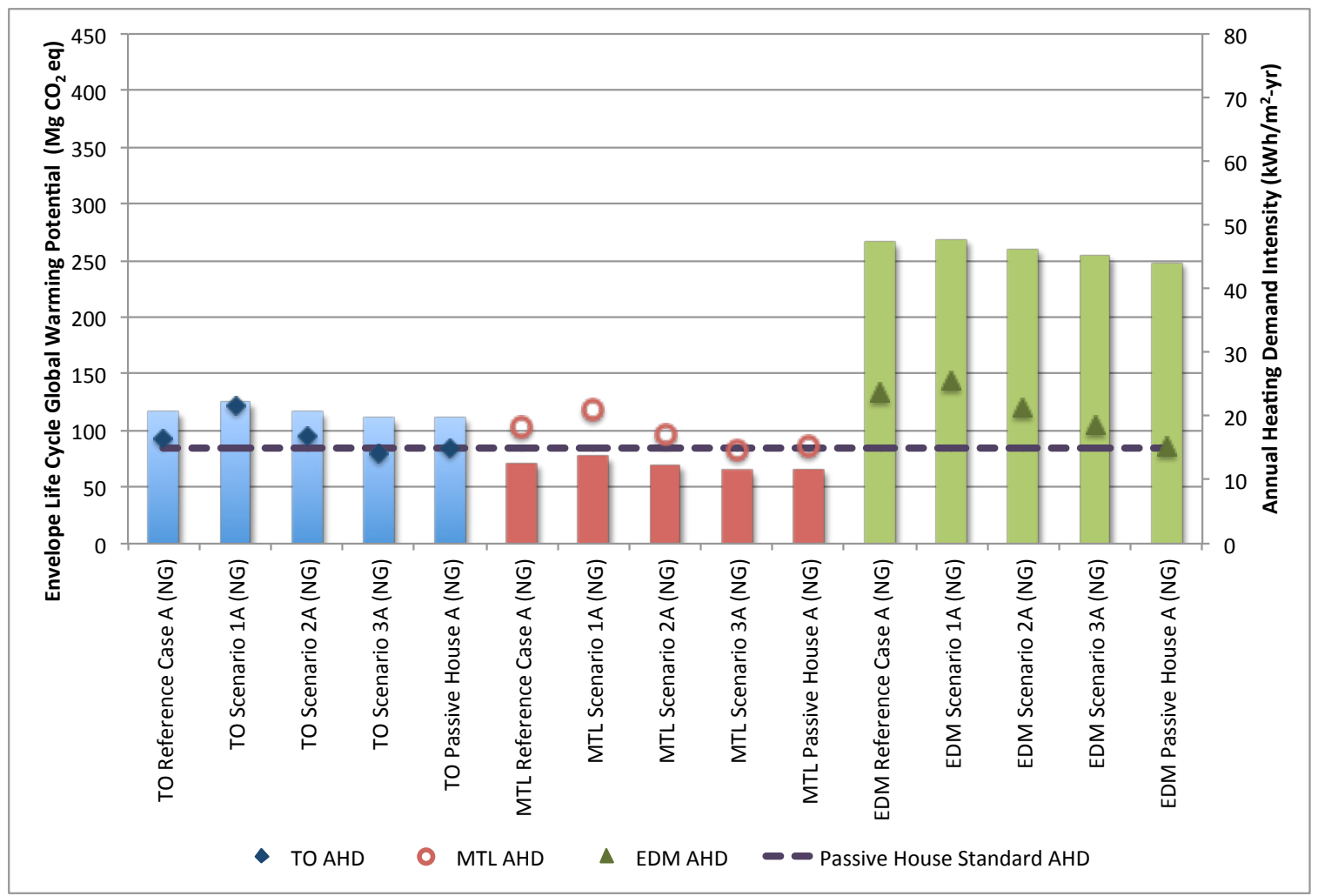

Figure 5-22 Case A (NG): Life Cycle GWP and AHD Intensity of Building Envelope Scenarios

Results for Case B (Electric) (Figure 5-23) show even greater differences in life cycle GWP than for Case A (NG). The scenario designed to meet the Passive House Standard in Montreal results in minimal life cycle GWP impact, while the Passive House scenarios located in Toronto and Edmonton yield result that are approximately 4,500\% and 18,500\% greater than for Montreal. 


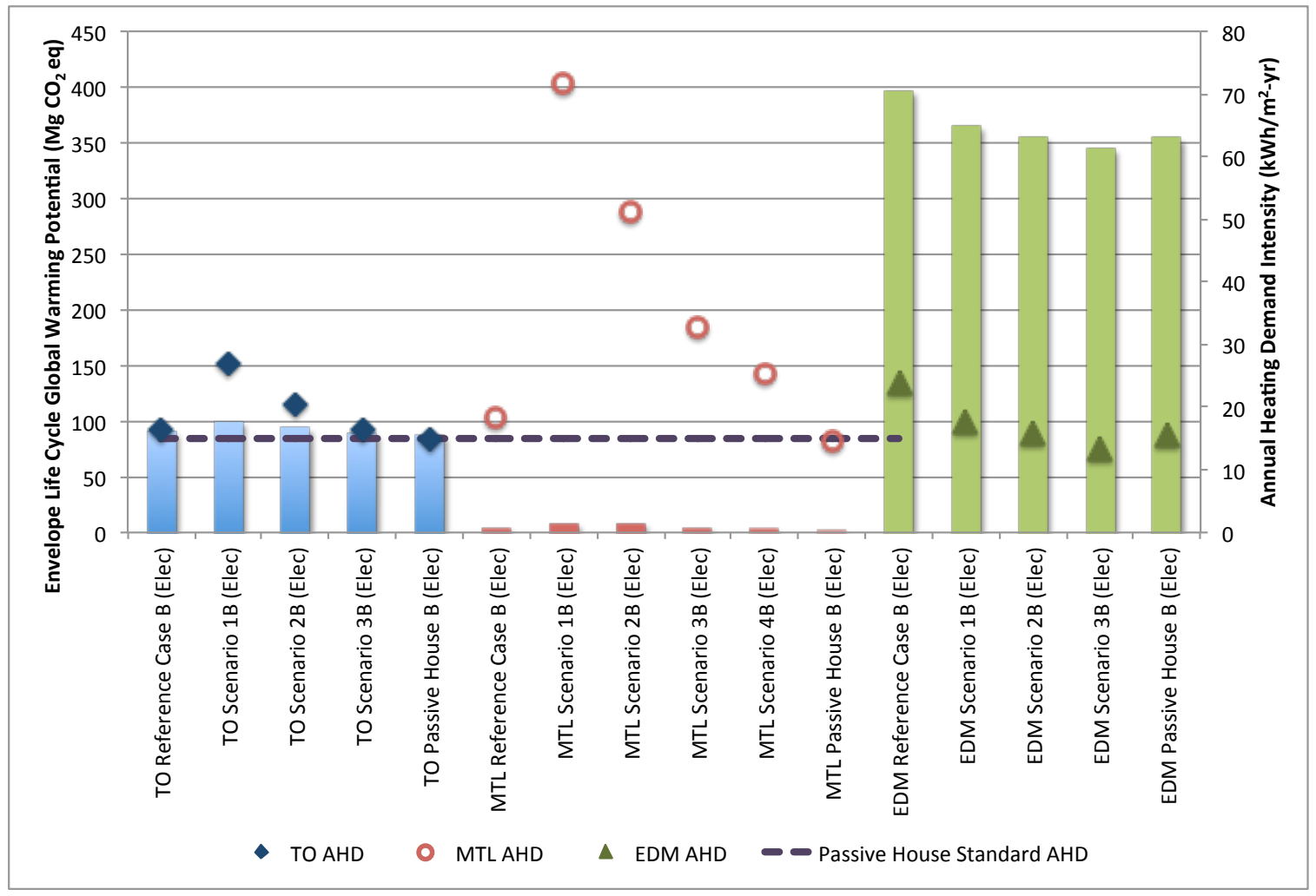

Figure 5-23 Case B (Electric): Life Cycle GWP and AHD Intensity of Building Envelope Scenarios

Annual heat demand and life cycle GWP results were plotted against each other in Figure 5-24 and Figure 5-25. Slope values of the linear trend lines were analyzed to determine the relationship between the two variables (Table 5-19). 


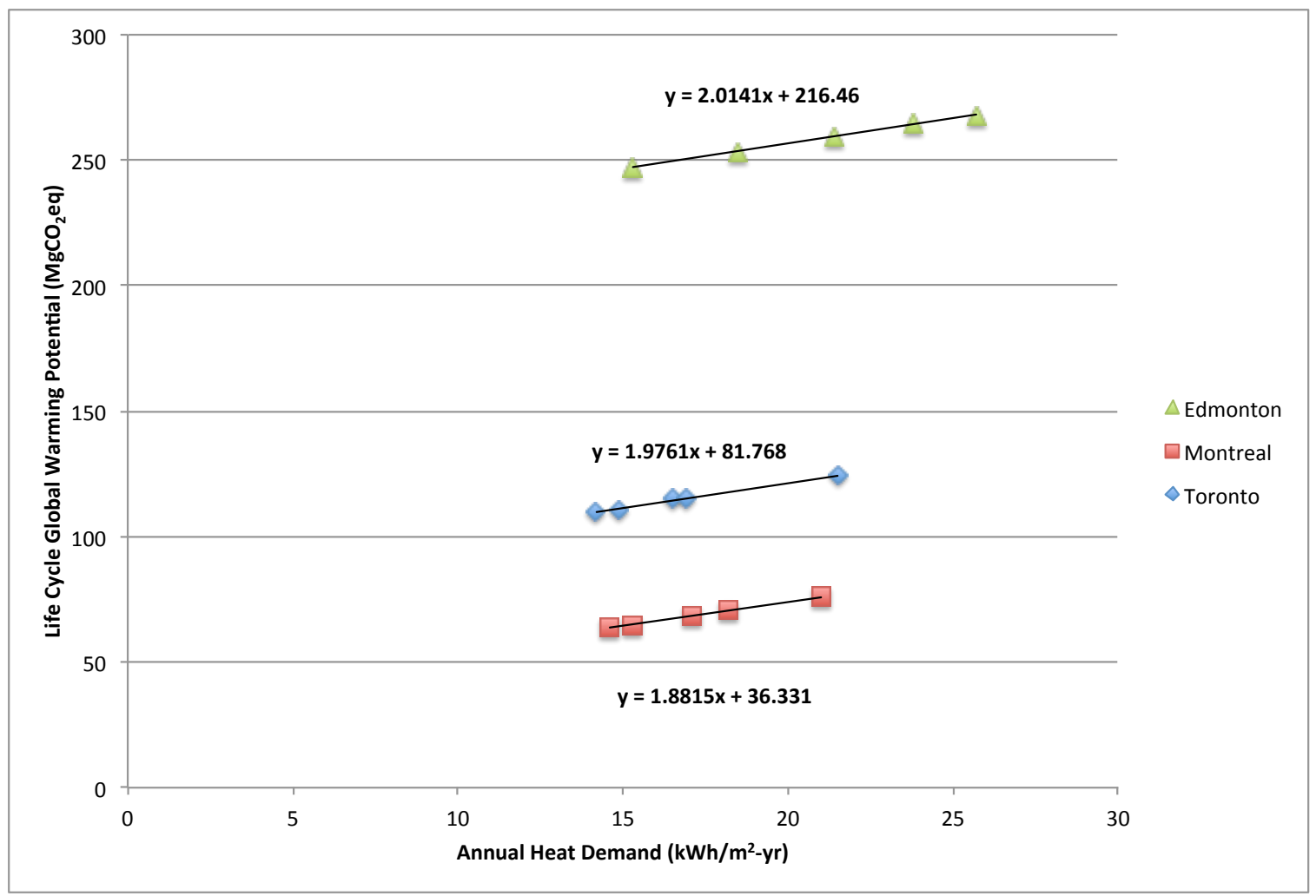

Figure 5-24 Case A: Relationship Between Life Cycle GWP and Annual Heat Demand

Slope values for Case A (NG) mechanical systems are nearly the same for Toronto and Edmonton, while the slope for Montreal is slightly lower. For Case A $(\mathrm{NG})$, changing the building annual heat demand by $1 \mathrm{kWh} / \mathrm{m}^{2}$-yr produces a change in life cycle GWP of approximately $2 \mathrm{Mg} \mathrm{CO}_{2} \mathrm{eq}$. This indicates that implementing measures that reduce the rate of heat loss, such as increasing envelope thermal resistance, airtightness, and ventilation system efficiency are effective at reducing life cycle carbon emissions. It also validates the Passive House Standard AHD criteria as an effective method for reducing the carbon impact of buildings when using natural gas mechanical systems.

The analysis was limited to assessing the impacts of the building envelope configuration with low embodied GWP. It should be noted that selecting insulation and cladding materials with higher embodied GWP could have a significant impact on the relationship between AHD and life cycle GWP, especially in locations with low 
electricity grid carbon intensities. Therefore, expanding the investigation to determine the sensitivity of GWP to envelope material choice is recommended.

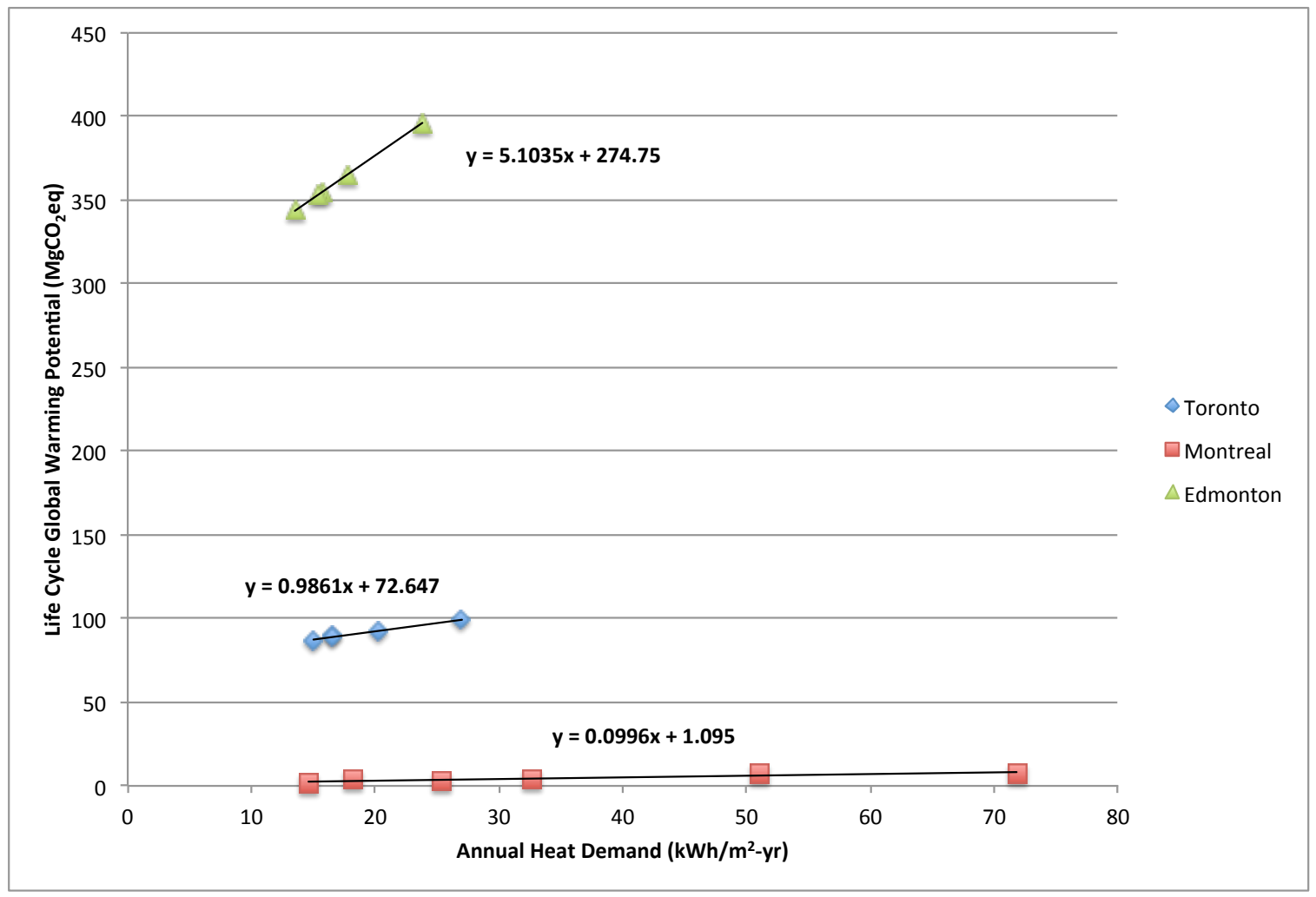

Figure 5-25 Case B: Relationship Between Life Cycle GWP and Annual Heat Demand

The slope values determined for Case B (Electric) mechanical systems were significantly different from Case $\mathrm{A}(\mathrm{NG})$ and between locations. AHD and life cycle GWP have a near-proportional (1:1) relationship in Toronto. Adjusting the AHD of a building in Montreal produces very little change in life cycle GWP, while the opposite is true for Edmonton, where altering the AHD has a significant impact on life cycle GWP. The link between electricity grid carbon intensity and life cycle GWP is clear, with the majority of emissions arising due to operating impacts for regions with high electricity carbon intensity. An additional component for the disparity between locations is due to the differences in backup electric resistance heating required to meet the heating demand. Toronto did not require backup heating, while for Edmonton, $13 \%$ of the total heat demand was supplied by backup heat. 
Table 5-19 Summary of Trendline Slope Analysis

\begin{tabular}{|l|r|}
\hline Location & $\begin{array}{l}\text { Trendline Slope } \\
\left(\mathrm{MgCO}_{2} \mathrm{eq} /\left[\mathrm{kWh} / \mathrm{m}^{2}-\mathrm{yr}\right]\right)\end{array}$ \\
\hline Case A (NG) & 1.98 \\
Toronto & 1.88 \\
Montreal & 2.01 \\
\hline Edmonton & \\
\hline Case B (Electric) & 0.99 \\
Toronto & 0.10 \\
Montreal & 5.10 \\
Edmonton & \\
\hline
\end{tabular}

The Passive House Standard criterion for AHD is very effective at achieving its goal of carbon reductions in locations with high electricity grid carbon intensities, while the AHD criterion does not produce meaningful reductions in locations with low electricity grid carbon intensities. Despite this finding, the electricity saved in low carbon regions such as Quebec could allow for increased exports to neighbouring regions, thereby resulting in a reduction of building operating GWP in regions outside of Quebec. Therefore, the complexities of inter-regional electricity grid dynamics and the associated impact on building life cycle GWP are areas requiring further investigation in order to increase the accuracy in predicting the impact of constructing to the Passive House Standard. Furthermore, although not assessed in this study, consideration of the additional advantages of constructing to the Passive House Standard such as increased occupant comfort and envelope durability, can provide further justification for super insulating buildings. 


\section{Conclusions and Recommendations}

The investigation of life cycle carbon impacts of Passive House building envelopes yielded several important findings. First off, the impact of envelope material choice on life cycle GWP was found to be greatest in locations with access to low carbon electricity when electric based mechanicals are used, while having a negligible impact in regions supplied by high carbon electricity when either natural gas or electric mechanicals are used. Hence, optimization of envelope embodied GWP should be a main consideration for buildings located in regions with access to low carbon energy, while priority should be given to reducing operating GWP for buildings in regions with high carbon energy sources.

An assessment of the GWP impact of different envelope materials indicated that wall cladding material choice could have a larger influence on envelope embodied GWP than insulation choice, especially in regions with low carbon electricity. Additionally, the investigation found that assemblies primarily incorporating wood products for structure, insulation and cladding reduce the total life cycle GWP of buildings if sourced from regions with low carbon electricity. It is important to note that this finding is only valid if wood materials are obtained from sources with sustainable forestry practices in place (Nunery \& Keeton, 2010). Also, since this study was based on average regional embodied GWP impacts and did not investigate the impact of windows, a complete case-specific accounting of life cycle GWP impacts may yield different outcomes. Moreover, expanding the study to include embodied impacts of interior finishes, fixtures, appliances and mechanical systems may indicate that one of these building components have a greater influence on total life cycle GWP than the building envelope or operating impacts.

An analysis of the impact that insulation thickness has on envelope life cycle GWP found that all permutations of location and mechanical system type yield diminishing returns in life cycle GWP reductions with increasing insulation thickness. Buildings located in areas with high carbon electricity sources were found to offer the greatest opportunity for further reductions in envelope life cycle GWP 
beyond reference building insulation levels, while increasing envelope insulation in locations with access to low carbon electricity was found to have insignificant impacts on life cycle GWP. These results corroborate the findings of research conducted by Bowick (2011), which indicated that climate and fuel mix have the greatest influence on life cycle GWP.

A comparison of mechanical systems indicated that using electric heat pumps for space heat and domestic hot water in locations with low carbon electricity results in fewer operating emissions than using a natural gas combined boiler system. Furthermore, this study predicted that natural gas mechanical systems are better at reducing the operating GWP impact of buildings constructed to the Passive House Standard in locations where electricity is supplied from high carbon sources. However, changes to electricity grid carbon intensity over the mechanical equipment life span may result in significant deviations in predicted operating GWP. Thus, decisions made about mechanical systems should reflect both current and anticipated carbon intensities of the energy carrier selected over the expected lifespan of the equipment.

Although this study indicates that only small reductions in carbon emissions are realized from building to the Passive House Standard within the region of Quebec, the impact of exporting low carbon electricity was not taken into account. It may be that the electricity saved by building to the Standard would allow for an increase in exports to neighbouring regions, thus helping to reduce the carbon impact of buildings elsewhere. Therefore, the complexities of inter-regional electricity grid dynamics and the associated impact on building life cycle GWP are areas requiring further investigation to more accurately assess the life cycle GWP impact of constructing to the Passive House Standard. Furthermore, several other important reasons exist for encouraging the design of super-insulated envelopes, including their contribution to high levels of indoor air quality by eliminating conditions favourable for mould growth and ensuring occupant comfort by maintaining interior envelope surface temperatures close to the indoor air temperature (Cotterrell \& Dadeby, 2012). 
When compared with a region specific method for determining operating GWP, the Passive House Standard calculation method was found to significantly overestimate emissions of natural gas mechanical systems for locations with low carbon electricity, while also moderately underestimating emissions for locations with high carbon electricity. The departure in results between the two methods was found to be even greater for heat pump electric mechanical systems. Therefore, the single North American carbon emission factor used in the Passive House Standard method should not be relied upon when evaluating operating GWP of mechanical system options. Incorporation of regional based electricity grid carbon emission factors into the Passive House Standard would assist designers in selecting mechanical systems and fuel types with lower life cycle operating carbon impacts, thus satisfying the underlying principle of the Passive House Standard. 


\section{Future Work}

Since the application of life cycle assessment to Passive House buildings is quite recent, the potential exists for significant further research in this area. The following topics related to this study have been identified as requiring further investigation:

- Expand the research to include the impact of imported specialty products and materials, such as high-performance windows;

- Assess the embodied impact of windows, mechanical systems and the life cycle impact of changing window to wall ratios;

- Increase the scope to include other Passive House building typologies such as multi-family residential and institutional;

- Analyze the impact of different wall types, such as structural insulating panels and insulating concrete forms;

- Evaluate additional mechanical systems and fuel types suitable for Passive Houses, such as wood and hybrid fuel systems;

- Assess the impact of onsite renewable energy generation on Passive House life cycle GWP;

- Assess the sensitivity of operating impacts to changes in energy source carbon intensity, and;

- Extend the operating GWP analysis to incorporate inter-regional electricity system dynamics. 


\section{Appendix A}

WUFI Passive Whole Building Energy Modeling Procedure 


\section{WUFI Passive Whole Building Energy Modeling Procedure}

The following section provides a detailed description of the method used for modeling the reference building, including detailed parameter inputs and their supporting calculations and assumptions. Notes beside each parameter in bold and italics represent supporting assumptions and data sources.

\section{Project Information}

Primary Energy Factor

"Primary energy/CO2-factor" Tab

Selection: Standard USA - North American value currently accepted by PHIUS for certification (PHIUS, 2014c)

\section{Building Details}

"Orientation": South

"Building Wizard": Enter following parameters:

Main Floor Dimensions

$\mathrm{L}=9.13 \mathrm{~m}$ - from average Canadian single-detached home floor area.

Represents exterior dimensions, since average floor area is calculated to the outside of building

$\mathrm{W}=9.13 \mathrm{~m}$

Story Height $=2.8 \mathrm{~m}$ - value required by PHIUS for certification (2.5 m) + floor joist height (PHIUS, 2014c)

First Floor Height $=2.8 \mathrm{~m}$ - value required by PHIUS for certification $(2.5 \mathrm{~m})+$ floor joist height (PHIUS, 2014c)

\section{Roof Geometry}

h1 = 0.305 - from Reference Building design raised heel truss $-12 "$ raised = $0.305 \mathrm{~m}$

Roof inclination $=40$ degrees - from Reference Building design

Gable ends - (selected)

Roof offset $=0.8 \mathrm{~m}-$ default

\section{Foundation Geometry}

Slab on grade selected, no options to fill in 


\section{Building}

\section{PH case: Residential}

General

Parameters - all set to defaults

Zones - default

\section{Additional Data Module:}

Preferred minimum indoor temp... = 20 - default (PHIUS, 2014c)

Overheating temperature threshold = 25 - default (PHIUS, 2014c)

Fresh air per person $=30.5603-$ default (PHIUS, 2014c)

Infiltration (ACH 50) = 0.6 - assumption: the building is meeting the PH standard Net air volume for press. Test $=359.5 \mathrm{~m}^{3}$ - calculated in Equation A-1, according

to PHIUS (2013b):

$$
V n_{50}=h_{i} \cdot\left(l_{\text {ext }}-2 \cdot\left(d_{\text {wall }}\right)\right) \cdot\left(w_{\text {ext }}-2 \cdot\left(d_{\text {wall }}\right)\right)
$$

\section{Where:}

$V n_{50}=$ net air volume for pressure test, $\mathrm{m}^{3}$

$h_{i}=$ internal floor to ceiling height, $\mathrm{m}$

$l_{\text {ext }}=$ exterior length of building, $\mathrm{m}$

$d_{\text {wall }}=$ thickness of exterior wall, $\mathrm{m}$

$w_{\text {ext }}=$ exterior width of building, $\mathrm{m}$

Type of ventilation system $=$ Balanced $\mathrm{PH}$ ventilation - default

Summer night ventilation = None - assumption: represents worst -case

humidity ration (if dehumidification) $[\mathrm{g} / \mathrm{kg}]=12$-default according to PHIUS

(2014c)

Building wind exposure $=$ Several sides exposed - No screening - assumption:

represents worst-case

Wind screening coefficient $(\mathrm{e})=0.1$ - default

Optional data (if not defined default value will be calculated) - all defaults according to PHIUS (2014c)

\section{Foundation Interface}

Setting/type

Setting $=$ User defined

Type $=$ Slab on grade 
Area of slab $=70.69 \mathrm{~m}^{2}$ - determined from Reference Building design using AutoCAD (excludes perimeter insulation thickness)

Average U-value of slab on grade $\left[\mathrm{W} / \mathrm{m}^{2} \mathrm{~K}\right]=0.138$ - calculated from Reference Building slab design (see Appendix B)

Slab perimeter $(\mathrm{P})=33.63 \mathrm{~m}$ - determined from Reference Building design using AutoCAD

\section{Additional Parameters}

Position of the perimeter insulation = Vertical - from Reference Building design Perimeter insulation width/depth $=0.3173 \mathrm{~m}$ - from Reference Building design from top of slab to bottom of insulation (clear stone)

Conductivity perimeter insulation $[\mathrm{W} / \mathrm{mK}]=0.036$ - from Reference Building design - value for EPS from WUFI Passive North American database

Optional data (if not defined default value will be calculated)

Photovoltaic annual electricity generation $[\mathrm{kWh} / \mathrm{a}]=0$ default (PHIUS, 2014c) DHW consumption (60C) per person per day [L/Person/day]= 25 default (PHIUS, 2014c)

Average cold water temperature - supply [C] = 17 - assuming efficient drain water heat recovery system, calculated according to PHIUS+ pre-certifier, G. Wright (personal communication, January 10, 2014).

Zone 1: Simulated zone:

Project information - defaults

Geometry / Specific heat capacity

Reference volume = "From visualized geometry" = 466.8 - auto calculated by WUFI Passive

Gross volume $=$ "From reference volume and components" $=466.8$ (external volume) - auto calculated by WUFI Passive

Treated floor area = Estimated from gross volume" $=119 \mathrm{~m}^{2}-$ confirmed through calculation of treated floor area in Table A - 1, according to methodology by PHIUS (2014c) 
Table A - 1 Treated Floor Area Calculation

\begin{tabular}{|c|c|c|c|c|}
\hline Level & Room & $\begin{array}{l}\text { Area }^{a} \\
\left(m^{2}\right)\end{array}$ & $\begin{array}{l}\text { Multiplier } \\
(-)\end{array}$ & $\begin{array}{l}\text { Treated Floor Area } \\
\left(\mathrm{m}^{2}\right)\end{array}$ \\
\hline \multirow{8}{*}{ 1st story } & Living Room \& Foyer & 19.80 & 1 & 19.80 \\
\hline & Kitchen & 13.82 & 1 & 13.82 \\
\hline & Dining & 18.40 & 1 & 18.40 \\
\hline & Understair full height & 1.40 & 1 & 1.40 \\
\hline & Understair & 1.50 & 0.5 & 0.75 \\
\hline & Entrance closet & 0.80 & 1 & 0.80 \\
\hline & Powder room & 2.20 & 1 & 2.20 \\
\hline & Mechanical Room & 3.40 & 0.6 & 2.04 \\
\hline \multirow{8}{*}{ 2nd story } & Bedroom 1 & 10.40 & 1 & 10.40 \\
\hline & Bedroom 2 & 10.20 & 1 & 10.20 \\
\hline & Bedroom 3 (MBR) & 16.90 & 1 & 16.90 \\
\hline & Ensuite & 4.90 & 1 & 4.90 \\
\hline & Bathroom & 5.00 & 1 & 5.00 \\
\hline & Corridor & 7.50 & 1 & 7.50 \\
\hline & Laundry & 2.20 & 1 & 2.20 \\
\hline & Walk in closet & 2.50 & 1 & 2.50 \\
\hline Totals & Area = & 120.92 & TFA = & 119 \\
\hline \multicolumn{5}{|l|}{ Notes: } \\
\hline \multicolumn{5}{|c|}{$\begin{array}{l}{ }^{\mathrm{a}} \text { All area take-offs obtained from reference } \\
\text { b } \text { Determined according to PHIUS (2013b) }\end{array}$} \\
\hline
\end{tabular}

Clearance height = "Standard value" = 2.5 - according to PHIUS (2014c)

Specific heat capacity = "Lightweight" $=60$ - conservative assumption

\section{Additional data}

Humidity capacity = 700 - default value recommended by WUFI Passive

\section{Building Assemblies}

\section{Visualized components:}

\section{Component 1: Slab:}

Type/Attachment:

Type $=$ Opaque

Inner side $=$ Zone 1: Simulated zone

Outer side $=$ Ground

Data: - all values auto-filled by WUFI Passive 
Parameters: - all values auto-filled by WUFI Passive

Surface:

Heat transfer resistance: "According to component type"

Component 2: $2^{\text {nd }}$ Floor Header: - no options to enter

Component 3: Walls:

"General" Tab

Type/Attachment:

Type $=$ Opaque

Inner side $=$ Zone 1: Simulated zone

Outer side $=$ Outside air

Data: - all values auto-filled by WUFI Passive

Parameters: - all values auto-filled by WUFI Passive

Surface:

Heat transfer resistance: "According to component type"

Solar absorption/emission (exterior surface): “Wood (spruce): painted brown

Component 4: Attic Ceiling

"General" Tab

Type/Attachment:

Type $=$ Opaque

Inner side = Zone 1: Simulated zone

Outer side $=$ Outside air

Data: - all values auto-filled by WUFI Passive

Parameters: - all values auto-filled by WUFI Passive

"Assembly" Tab

Assigned assembly:

Name - Attic Ceiling

"Surface" Tab

Heat transfer resistance: "According to component type" 


\section{Component 5: Exterior Door}

"General" Tab

Type/Attachment:

Type $=$ Opaque

Inner side $=$ Zone 1: Simulated zone

Outer side $=$ Outside air

Data: - all values auto-filled by WUFI Passive

Parameters: - all values auto-filled by WUFI Passive

"Assembly" Tab

Assigned assembly:

Name - Exterior Door

"Surface" Tab

Heat transfer resistance: "According to component type"

\section{Component 6-22: [Windows]}

The required details were entered for each window using PHIUS certified data sets (PHIUS, 2014b). A summary of window parameters is shown in Table A - 2

"General" Tab

Type/Attachment:

Type $=$ Transparent

Inner side $=$ Zone 1: Simulated zone

Outer side $=$ Outer air

Data: - all values auto-filled by WUFI Passive

Parameters: - all values auto-filled by WUFI Passive 
Table A - 2 Summary of Modeled Window Parameters

\begin{tabular}{|c|c|c|c|c|c|}
\hline Component \# & Orientation & Location & $\begin{array}{l}\text { Area } \\
\left(\mathrm{m}^{2}\right)\end{array}$ & $\begin{array}{l}\text { Whole Window } \\
\text { U-value } \\
\left(\mathrm{W} / \mathrm{m}^{2}-\mathrm{K}\right)\end{array}$ & $\begin{array}{l}\text { SHGC }^{\text {b }} \\
(-)\end{array}$ \\
\hline 6 & 5 North & 1st Floor & 0.91 & 0.81 & 0.375 \\
\hline 7 & 7 North & 2nd Floor & 0.67 & 0.84 & 0.375 \\
\hline 8 & 3 West & 1st Floor & 0.91 & 0.87 & 0.556 \\
\hline 9 & 9 West & 1st Floor & 1.22 & 0.82 & 0.556 \\
\hline 10 & West & 2nd Floor & 1.22 & 0.77 & 0.469 \\
\hline 11 & 1 West & 2nd Floor & 0.9 & 0.84 & 0.556 \\
\hline 12 & 2 South & 1st Floor & 1.22 & 0.82 & 0.556 \\
\hline 13 & 3 South & 1st Floor & 1.22 & 0.82 & 0.556 \\
\hline 14 & 4 South & 1st Floor & 1.22 & 0.82 & 0.556 \\
\hline 15 & South & 1st Floor & 2.43 & 0.72 & 0.469 \\
\hline 16 & 5 South & 2nd Floor & 0.67 & 0.88 & 0.556 \\
\hline 17 & 7 South & 2nd Floor & 2.43 & 0.72 & 0.469 \\
\hline 18 & 8 East & 2nd Floor & 2.43 & 0.72 & 0.469 \\
\hline 19 & 9 East & 1st Floor & 0.9 & 0.79 & 0.469 \\
\hline 20 & East & 1st Floor & 0.9 & 1.02 & 0.556 \\
\hline 21 & 1 East & 2nd Floor & 0.67 & 0.88 & 0.556 \\
\hline 22 & 2 East & 2nd Floor & 0.67 & 0.88 & 0.556 \\
\hline
\end{tabular}

\section{Notes:}

a Values calculated by WUFI Passive

${ }^{b}$ Values from PHIUS certified window data (PHIUS, 2014d)

"Window Parameters" Tab

Assigned window type

Name: Alpen 725 Casement - High SHGC

"Solar protection" tab

"General" sub tab

Shading Parameters

Depth of window reveal ${ }^{*}[\mathrm{~m}]=0.1$

Distance from daylight opening to reveal ${ }^{*}[\mathrm{~m}]=0.05$

Height of landscape obstruction* $[\mathrm{m}]=0$

Distance of landscape obstruction* $[\mathrm{m}]=0$ assumption: no landscape obstructions are present

Other shading fraction of solar exposure (1=full exposure $)^{*}[-]=1$ 
Other shading summer fraction of solar exposure (1=full exposure $)^{*}[-]=1$

Total shading reduction factor [-]

Auto-calculated values reported by WUFI Passive

"Sunscreen device" sub tab

Sunscreen device reduction factor $=0.7$ - assumed for all windows, based on WUFI

Passive value for interior blinds

Not visualized components

BLANK - No data entered

Internal Loads/Occupancy

Humidity sources $\left[\mathrm{g} / \mathrm{m}^{2} \mathrm{~h}\right]=2$ - default value recommended by PHIUS (2014c)

\section{Ventilation System Utilization Pattern (Case A and Case B)}

\section{Calculation of Ventilation System Utilization Pattern}

The same ventilation system setup was used for both mechanical system cases. According to PHIUS (2014c), the maximum design ventilation rate is the greatest of the volumetric, supply air, and exhaust air requirements, as determined by Equations A-2 through A-7. The maximum ventilation rate was then used as the upper limit for the ventilation utilization pattern shown in Table A - 3. The fraction of design flow value was based on a ventilation utilization pattern for verification, given by PHIUS (2013b). The daily operating schedule was modified from the verification values by increasing the "Basic" operating time from 1.5 to 8 hours and "Max" from 0.5 to 2 hours. This was done to eliminate the model warning: "average air change rate is very low".

Maximum Ventilation Rate:

$$
V_{\text {max }}=\max \left\{V_{R}, V_{\text {Supply }}, V_{\text {Exhaust }}\right\}
$$

Where:

$V_{\max }=$ maximum ventilation rate, $\mathrm{m}^{3} / \mathrm{h}$

$V_{R}=$ volumetric ventilation requirement, $\mathrm{m}^{3} / \mathrm{h}$

$V_{\text {Supply }}=$ ventilation supply air requirement, $\mathrm{m}^{3} / \mathrm{h}$

$V_{\text {Exhaust }}=$ ventilation exhaust air requirement, $\mathrm{m}^{3} / \mathrm{h}$ 
Volumetric Requirement:

$V_{R}=V_{V} \cdot A C H_{\min }$

and

$\boldsymbol{V}_{V}=\boldsymbol{T F A} \cdot \boldsymbol{h}_{i}$

(A - 4)

Where:

$V_{V}=$ ventilation volume, $\mathrm{m}^{3} / \mathrm{h}$

$T F A=$ treated floor area, $\mathrm{m}^{2}$

$h_{i}=$ interior floor to ceiling height, $\mathrm{m}$

Supply Air Requirement:

$$
V_{\text {Supply }}=V_{F A} \cdot n
$$

Where:

$$
n=\# \text { bedrooms }+1
$$

$n=$ number of occupants, persons

\# bedrooms = the number of bedrooms in the house

$V_{F A}=$ ventilation fresh air requirement, $\mathrm{m}^{3} /$ person-h

Exhaust Air Requirement:

$\boldsymbol{V}_{\text {Exhaust }}=\sum\left(\boldsymbol{V}_{\text {kitchen }}+\mathbf{2} \cdot \boldsymbol{V}_{\text {bath }}+\boldsymbol{V}_{1 / 2 \text { bath }}\right)$

Where:

$V_{\text {kitchen }}=$ kitchen ventilation requirement, $\mathrm{m}^{3} / \mathrm{h}$

$V_{\text {bath }}=$ full-bath ventilation requirement, $\mathrm{m}^{3} / \mathrm{h}$

$V_{1 / 2 \text { bath }}=$ half-bath ventilation requirement, $\mathrm{m}^{3} / \mathrm{h}$

The required exhaust flow rates for each room type were defined by PHIUS (2013b). 
Table A - 3 Ventilation Utilization Pattern

\begin{tabular}{|lcrr|}
\hline Specification & $\begin{array}{l}\text { Daily operation } \\
\text { schedule } \\
\text { (h) }\end{array}$ & $\begin{array}{l}\text { Fraction of } \\
\text { design air flow } \\
(-)\end{array}$ & $\begin{array}{l}\text { Time Weighted } \\
\text { Flow Rate } \\
\mathrm{m}^{3} / \mathrm{h}\end{array}$ \\
\hline Max & 2 & 1 & 13.5 \\
Standard & 0 & 0.8 & 0.0 \\
Basic & 8 & 0.6 & 32.3 \\
Minimum & 14 & 0.4 & 37.7 \\
\hline Total daily average ventilation flow rate $=$ & $\mathbf{8 3 . 4}$ \\
\hline
\end{tabular}

\section{Summer Ventilation}

Summer natural ventilation (day) ACH $[1 / \mathrm{h}]=0$ - assume worst case = no windows are opened, therefore no natural ventilation

Summer mechanical ventilation $\mathrm{ACH}[1 / \mathrm{h}]=0.32$ - based on average ventilation rates result from initial modelling run as recommended by WUFI Passive and PHIUS (2014c)

Calculator summer ventilation

No data entered - assumption: no summer ventilation through windows occurs

\section{Thermal bridges}

Linear thermal bridges

No data entered - assumption: the design is thermal bridge free - design based on wall assemblies of the Dublin Passive House, which has negative thermal bridge values, therefore conservative

Attached zones:

Attached zones

Unheated attic

Attached zone 1: Unheated attic

Additional data

Temperature difference reduction factor [-] = 1 - based on WUFI Passive recommended value for a well vented attic design where attic temperature is assumed to be at ambient temperature conditions

Component 1: Roof Surface

Auto-filled by WUFI Passive 


\section{Component 2: Roof Gable Ends}

Auto-filled by WUFI Passive

\section{Remaining elements:}

\section{Component 1: Roof Overhangs}

Type/Attachment

Type: Opaque

Inner side: Outer air

Outer side: Outer air

\section{Component 2: Ground}

Type/Attachment

Type: Opaque

Inner side: Ground

Outer side: Outer air

\section{Mechanical Systems}

Two mechanical systems evaluated were defined as follows:

Case A: A natural gas combination boiler was selected to provide space heating and DHW, based on consultation with S. Fix, a mechanical engineer specializing in cold-climate Passive House design (personal communication, March 27, 2014). An electric air-to-air mini-split heat pump was selected to supply the air conditioning needs.

Case B: An electric air-to-air mini-split heat pump was chosen for space heating and air-conditioning, while baseboard electric resistance was used as a backup source (to meet peak heat load conditions). An electric air-towater heat pump hot water system was used to supply the DHW needs.

\section{Case A Mechanical System Inputs}

Case A mechanical systems are summarized in Table A - 4. 
Table A - 4 Case A: Summary of Mechanical System Configuration

\begin{tabular}{|l|l|l|l|l|l|}
\hline $\mathbf{N r}$ & Type & Space Heating & DHW & Space Cooling & Space Ventilation \\
\hline 1 & Boiler & X & X & & \\
\hline 2 & Heat Pump & & & X & \\
\hline 3 & $\begin{array}{l}\text { Mechanical } \\
\text { Ventilation }\end{array}$ & & & & $X$ \\
\hline
\end{tabular}

\section{Heating and Domestic Hot Water System (Case A)}

A combination natural gas-fired boiler was selected to supply heating and domestic hot water for Case A. WUFI Passive input parameters for these systems were provided by J. Amlin of Viessmann (personal communication, May 13, 2014) and are summarized in Table A - 5.

\section{Additional Inputs:}

Device 1 (Boiler: Heating, DHW): Viessmann Vitodens 222-F 19

Energy source $/$ boiler type $=$ Gas

Table A - 5 Case A: Heating and Domestic Hot Water System Properties

\begin{tabular}{|l|l|}
\hline Condensing boiler? & Yes \\
\hline Boiler efficiency at $30 \%$ load $[-]$ & 0.98 \\
\hline Boiler efficiency at nominal output $[-]$ & 0.952 \\
\hline Average return temp at $30 \%$ load $\left[{ }^{\circ} \mathrm{C}\right]$ & 30 \\
\hline Average boiler temp at design $70^{\circ} \mathrm{C} / 55^{\circ} \mathrm{C}\left[{ }^{\circ} \mathrm{C}\right]$ & 62.5 \\
\hline Average boiler temp at design $55^{\circ} \mathrm{C} / 45^{\circ} \mathrm{C}\left[{ }^{\circ} \mathrm{C}\right]$ & 50 \\
\hline Average boiler temp at design $38^{\circ} \mathrm{C} / 28^{\circ} \mathrm{C}\left[{ }^{\circ} \mathrm{C}\right]$ & 31.5 \\
\hline Maximum boiler power $[\mathrm{kW}]$ & 18 \\
\hline Standby heat loss boiler at $70^{\circ} \mathrm{C}[-]$ & 0.0019 \\
\hline Auxiliary energy (electric power) $[\mathrm{W}]$ & 141 \\
\hline Auxiliary energy DHW (electric power) $[\mathrm{W}]$ & 232 \\
\hline Within thermal envelope? & Yes \\
\hline Solar fraction for space heating $[-]$ & 0 \\
\hline Note: All values provided by manufacturer (Viessmann) \\
\hline
\end{tabular}




\section{Hydronic Heating System Distribution (Case A)}

A hydronic heating system was only required to distribute heating supplied by the gas boiler for Case A. Hydronic heating system properties input into WUFI Passive are summarized in Table A - 6.

Table A - 6 Case A Hydronic Distribution System Properties

\begin{tabular}{|l|l|l|}
\hline Specification & Warm Region & Source \\
\hline $\begin{array}{l}\text { Length of distribution pipes } \\
{[\mathrm{m}]}\end{array}$ & 20 & $\begin{array}{l}\text { Calculated values from } \\
\text { Reference Building design }\end{array}$ \\
\hline $\begin{array}{l}\text { Heat loss coefficient per } \\
\text { meter pipe }[\mathrm{W} / \mathrm{mK}]\end{array}$ & 0.35 & Default \\
\hline Design flow temperature $\left[{ }^{\circ} \mathrm{C}\right]$ & 50 & $\begin{array}{l}\text { WUFl Passive } \\
\text { recommended value in } \\
\text { range of 50-60 }\end{array}$ \\
\hline $\begin{array}{l}\text { Design system heating load } \\
{[\mathrm{kW}]}\end{array}$ & 10.7 & Determined by model \\
\hline Flow temperature controlled? & Yes & \\
\hline
\end{tabular}

\section{Case A and Case B Systems}

Equipment or distribution systems that could be used with both Case A and Case B mechanical systems were kept constant. Therefore, only a single set of input parameters were required, as detailed in this section.

\section{DHW System Distribution (Case A and Case B)}

The distribution system for domestic hot water, defined in Table A - 7, was kept constant for both Cases A and B. 
Table A - 7 Domestic Hot Water Distribution System Properties

\begin{tabular}{|l|l|}
\hline Specification & Warm Region (assumptions/notes) \\
\hline Length of circulation pipes [m] & 0 (no HW recirculation system) \\
\hline $\begin{array}{l}\text { Heat loss coefficient per meter pipe [W/m- } \\
\mathrm{K}]\end{array}$ & 0.15 (WUFI Passive recommended value) \\
\hline $\begin{array}{l}\text { Temperature of the room the pipes pass } \\
\text { through }\end{array}$ & (No entry = default room temperature) \\
\hline Design flow temperature $\left[{ }^{\circ} \mathrm{C}\right]$ & 55 (WUFI Passive recommended value) \\
\hline Daily running hours of the circulation [h] & 0 (no HW recirculation system) \\
\hline Length of individual pipes [m] & $\begin{array}{l}20.4 \text { (calculated for Reference Building, } \\
\text { based on PHIUS (2014c)) }\end{array}$ \\
\hline Exterior pipe diameter [mm] & 15.88 (based on Reference Building design) \\
\hline
\end{tabular}

\section{Cooling Distribution System (Case A and Case B)}

Both Case A and Case B use the same air-to-air mini-split heat pump equipment to supply air conditioning. Although this particular system did not require ductwork, several inputs regarding the equipment were required. Input parameters for both Case A and Case B cooling systems did not change. Cooling distribution system inputs are summarized in Table A - 8.

Table A - 8 Cooling Distribution System Properties

\begin{tabular}{|l|l|}
\hline Cooling via air ventilation? & No \\
\hline Cooling via air recirculation? & Yes \\
\hline Dehumidification? & Yes \\
\hline Panel cooling? & No \\
\hline $\begin{array}{l}\text { Recirculating air-cooling with variable speed } \\
\text { compressor? }\end{array}$ & Yes \\
\hline $\begin{array}{l}\text { Minimum temperature of cooling coil surface } \\
\text { recirculation air }\left[{ }^{\circ} \mathrm{C}\right]\end{array}$ & 5 \\
\hline Note: & \\
\hline Values based on manufacturer data (Mitsubishi Mr. Slim Model MSZ-GE09NA) \\
\hline
\end{tabular}

\section{Ventilation System Distribution (Case A and Case B)}

Ventilation system layouts were kept constant for Cases A and B. Therefore the model input parameters summarized in Table A - 9 and Table A - 10 did not change. 
Table A - 9 Ventilation Distribution System Properties

\begin{tabular}{|l|l|l|l|l|}
\hline Name & Duct type & $\begin{array}{l}\text { Duct } \\
\text { shape }\end{array}$ & Quantity & $\begin{array}{l}\text { Duct } \\
\text { length } \\
\text { [m] }\end{array}$ \\
\hline Main Supply to ERV & Supply/outdoor air duct & Round & 1 & 0.759 \\
\hline Main Extract from ERV & Extract/ exhaust air duct & Round & 1 & 2 \\
\hline Note: data based on Reference Building design
\end{tabular}

Table A - 10 Additional Ventilation Distribution System Properties

\begin{tabular}{|l|l|l|}
\hline $\begin{array}{l}\text { Duct diameter, Nominal width } \\
{[\mathrm{mm}]}\end{array}$ & 200 & Calculated from Reference Building design \\
\hline Insulation thickness [mm] & 100 & $\begin{array}{l}\text { Passive House standard minimum required } \\
\text { insulation }\end{array}$ \\
\hline Thermal conductivity $[\mathrm{W} / \mathrm{mK}]$ & 0.04 & Assumed based on insulation type \\
\hline Is reflective? & Yes & Based on insulation type \\
\hline
\end{tabular}

\section{Cooling System (Case A and Case B)}

Both Case A and Case B use the same air-to-air mini-split heat pump equipment to supply air conditioning, therefore the input parameters do not change. The cooling system input for WUFI Passive is summarized in Table A - 11.

\section{Calculation of Cooling System Performance}

The dimensionless coefficient of performance value is calculated from the manufacturer's data for energy efficiency ratio (EER), as follows (Fairey, Parker, Wilcox, \& Lombardi, 2004):

$$
\text { COP } \text { cooling }=\frac{E E R}{3.412 B T U / W h}
$$

Where:

$C O P_{\text {cooling }}=$ heat pump cooling season coefficient of performance $E E R=$ energy efficiency ratio, BTU/Wh 


\section{Additional Inputs:}

Device 2 (Heat pump: Cooling, Dehumidification): Mitsubishi Mr. Slim Mini-Split HP

Table A - 11 Case A: Cooling System Properties

\begin{tabular}{|l|l|}
\hline Type & Heat Pump \\
\hline Annual cooling COP [-] & 3.99 \\
\hline Note: & Values based on manufacturer data (Mitsubishi Mr. Slim Model MSZ-GEO9NA) \\
\hline
\end{tabular}

\section{Ventilation System (Case A and Case B)}

The Ultimate Air RecoupAerator 200 DX ERV was selected to provide ventilation with efficient heat recovery. Although the stated energy transfer efficiency of the unit is 95\%, it lacked certification from the Home Ventilating Institute (HVI), or the Passive House Institute. The protocol for Passive House modeling requires that ventilation equipment lacking certification be de-rated to account for in-situ performance (PHIUS, 2014c). Therefore, the 200 DX has a de-rated efficiency of $83 \%$ (UltimateAir, 2014). The model input parameters were kept constant between the two mechanical system cases, as summarized in Table A - 12 .

\section{Table A - 12 Ventilation System Properties}

\begin{tabular}{|l|l|l|}
\hline HRV/ERV efficiency [-] & 0.83 & Manufacturer data (UltimateAir, 2014) \\
\hline Electric efficiency [Wh/m $\left.{ }^{3}\right]$ & 1.22 & Manufacturer data (UltimateAir, 2014) \\
\hline Equipped with frost protection? & Yes & $\begin{array}{l}\text { Determined from Reference Building } \\
\text { design }\end{array}$ \\
\hline Quantity & 1 & $\begin{array}{l}\text { Determined from Reference Building } \\
\text { design }\end{array}$ \\
\hline Humidity recovery efficiency [-] & 0.43 & Manufacturer data (UltimateAir, 2014) \\
\hline HRV/ERV in conditioned space? & Yes & $\begin{array}{l}\text { Determined from Reference Building } \\
\text { design }\end{array}$ \\
\hline $\begin{array}{l}\text { No summer bypass feature (summer } \\
\text { ventilation with HRV/ERV)? }\end{array}$ & No & $\begin{array}{l}\text { Determined from Reference Building } \\
\text { design }\end{array}$ \\
\hline $\begin{array}{l}\text { Defrost active } \\
\text { Temperature below which defrost } \\
\left.\text { must be used [ }{ }^{\circ} \mathrm{C}\right]\end{array}$ & Yes & $\begin{array}{l}\text { Determined from Reference Building } \\
\text { design }\end{array}$ \\
\hline Subsoil heat exchanger efficiency [-] & NA & Manufacturer data (UltimateAir, 2014b) \\
\hline
\end{tabular}




\section{Ventilation/Rooms (Case A and Case B)}

\section{Additional Inputs:}

Utilization Pattern: "Standard Operation" = 7 days/week, 52 weeks/year

The complete utilization pattern schedule was defined in Table A - 3.

Internal Loads/Occupancy (Case A and Case B)

\section{Additional Inputs:}

Humidity sources $(\mathrm{g} / \mathrm{m} 2 \mathrm{~h})=2$ - default recommended by WUFI Passive

\section{Device List (Appliances)}

Reference Building appliances were modeled by selecting values recommended in WUFI Passive. Appliance energy consumption remained unchanged for all modeling runs. A summary of appliance properties is presented in Table A - 13. 
Table A - 13 Summary of Appliance Properties

\begin{tabular}{|c|c|c|c|c|}
\hline Device/End use & Quantity & $\begin{array}{l}\text { Energy } \\
\text { demand }\end{array}$ & $\begin{array}{l}\text { In conditioned } \\
\text { space? }\end{array}$ & Additional info \\
\hline $\begin{array}{l}\text { Kitchen } \\
\text { dishwasher }\end{array}$ & 1 & $\begin{array}{l}1.1 \\
\text { kWh/Use }\end{array}$ & Yes & $\begin{array}{l}\text { DHW connection; } \\
\text { Recommended Values }\end{array}$ \\
\hline $\begin{array}{l}\text { Small } \\
\text { applications per } \\
\text { person }\end{array}$ & 1 & $\begin{array}{l}\mathrm{ED}=50 \\
\mathrm{kWh} / \mathrm{yr}\end{array}$ & Yes & $\begin{array}{l}\text { Passive House Standard } \\
\text { Entry }\end{array}$ \\
\hline $\begin{array}{l}\text { Laundry- } \\
\text { washer }\end{array}$ & 1 & $\begin{array}{l}0.95 \\
\text { kWh/Use } \\
\text { UF }=1\end{array}$ & Yes & $\begin{array}{l}\text { DHW connection; } \\
\text { Utilization factor } 1 ; \\
\text { Recommended Values }\end{array}$ \\
\hline Laundry-dryer & 1 & $\begin{array}{l}3.19 \\
\text { kWh/Use } \\
\text { RD }=0.6\end{array}$ & Yes & $\begin{array}{l}\text { Electric exhaust air } \\
\text { dryer; Remaining } \\
\text { dampness } 0.6\end{array}$ \\
\hline $\begin{array}{l}\text { Kitchen } \\
\text { fridge/freeze } \\
\text { combo }\end{array}$ & 1 & $0.7 \mathrm{kWh} / \mathrm{d}$ & Yes & Recommended Value \\
\hline Kitchen cooktop & 1 & $\begin{array}{l}0.2 \\
\text { kWh/Use }\end{array}$ & Yes & $\begin{array}{l}\text { Cooking with } \\
\text { electricity; Induction - } \\
\text { Recommended Value }\end{array}$ \\
\hline Lighting & 1 & $\begin{array}{l}\mathrm{HE}=0.8 \\
\mathrm{ED}=20.8 \\
W\end{array}$ & Yes & $\begin{array}{l}\text { Fraction high efficacy } \\
0.8\end{array}$ \\
\hline Plug loads & 1 & $\begin{array}{l}0.55 \\
k h /(P . a) \\
E D=80 \mathrm{~W}\end{array}$ & Yes & $\begin{array}{l}\text { Frequency } 0.55 \mathrm{kh} /(\mathrm{Pa}) \\
\text { Recommended Value }\end{array}$ \\
\hline
\end{tabular}

\section{Thermal Bridges}

Linear thermal bridges - none Assumption: no thermal bridging present due to design based on Dublin Passive House 


\section{Case B Mechanical Systems}

\section{Energy \& Ventilation Systems}

Case $B$ mechanical systems are summarized in

Table A - 14

Table A - 14 Case B: Summary of Mechanical System Configuration

\begin{tabular}{|l|l|l|l|l|l|}
\hline $\mathbf{N r}$ & Type & Space Heating & DHW & Space Cooling & Space Ventilation \\
\hline 1 & $\begin{array}{l}\text { Electric } \\
\text { heating/DHW }\end{array}$ & X & & & \\
\hline 2 & Heat Pump & X & & X & \\
\hline 3 & Heat Pump & & X & & \\
\hline 4 & $\begin{array}{l}\text { Mechanical } \\
\text { Ventilation }\end{array}$ & & & & $X$ \\
\hline
\end{tabular}

\section{Domestic Hot Water System (Case B)}

For Case B, an electric heat pump water heating system was selected as an energy efficient method of supplying domestic hot water using electricity. The specific unit used is a GE GeoSpring model GEH50DNSRSA. According to PHIUS (2013c), the annual COP of a heat pump hot water system located within the thermal envelope of a building must be de-rated to account for the heat that is lost from the conditioned space to the HPWH. This is to account for the additional heat demand that must be covered by the space conditioning system during the heating season. The efficiency of the additionally required heat supplied to the building depends on the type of heating system used (Ibid.).

\section{Calculation of HPWH System Performance}

Space conditioning demand is covered by an air-to-air heat pump system. Therefore, Equation A - 8 was used to de-rate the HPWH system annual COP to account for the resulting increase in space conditioning demand, according to PHIUS (2013c).

$$
H P W H C O P_{\text {Winter }}=\frac{1}{\frac{1}{E F}+\left(\frac{1}{\operatorname{COP} a d j}\right) \cdot\left(1-\frac{1}{E F}\right)}
$$


Where:

HPWH COP Winter $=$ heat pump water heater system COP during the heating season $\operatorname{COP}_{(\text {Adj })}=$ climate adjusted annual COP of heat pump

The COP of the HPWH system will increase during the cooling season. Therefore, according to PHIUS (2013c), the seasonal performance of the system must be taken into account in calculating the annual COP (Equation A - 9).

$$
\text { Annual COP }=\mathrm{EF} \cdot\left(\frac{t_{\text {Cooling Season }}}{t_{\text {Total }}}\right)+H P W H C O P_{\text {Winter }} \cdot\left(\frac{t_{\text {Heating Season }}}{t_{\text {Total }}}\right) \quad(\mathrm{A}-9)
$$

Where:

Annual COP = annual coefficient of performance

$E F=$ heat pump manufacturer's stated efficiency factor

$t_{\text {Cooling Season }}=$ length of cooling season, months

$t_{\text {Heating Season }}=$ length of heating season, months

$t_{\text {Total }}=$ length of year, 12 months

WUFI Passive requires the input of the Total System Performance ratio, which is equivalent to the inverse of the adjusted COP (Equation A - 10).

$$
T S P R=\frac{1}{\operatorname{COP}_{(A d j)}}
$$

Where:

$T S P R=$ total system performance ratio

$\operatorname{COP}_{(\text {Adj })}=$ climate adjusted annual COP of heat pump

WUFI Passive inputs used for the heat pump water heater are summarized in Table A - 15.

Table A - 15 Case B DHW System Properties

\begin{tabular}{|l|l|l|}
\hline Location & $\begin{array}{l}\text { Adjusted Annual } \\
\text { COP [-] }\end{array}$ & $\begin{array}{l}\text { Total System } \\
\text { Performance [-] }\end{array}$ \\
\hline Toronto & 1.60 & 0.63 \\
\hline Montreal & 1.55 & 0.64 \\
\hline Edmonton & 1.48 & 0.68 \\
\hline \multicolumn{2}{|l|}{ Note: All values calculated based on PHIUS (2013c). } \\
\hline
\end{tabular}




\section{Heating and Cooling System (Case B)}

A Mitsubishi Mr. Slim Model MSZ-GE09NA air-to-air heat pump system was specified to provide both heating and cooling for Case B. The amount of electrical energy consumed by the heat pump relative to the amount of heat energy transferred into the conditioned space is known as the Coefficient of Performance (COP) of the system. WUFI Passive requires an adjusted annual heating COP to be input to account for changes in performance when using the equipment in a climate zone different from the one used by the manufacturer to obtain the COP value (PHIUS, 2013c). Since this value varies between climates it must be determined for each of the three locations evaluated.

Table A - 16 Case B: Heating and Cooling System Properties

\begin{tabular}{|l|l|l|l|}
\hline Location & $\begin{array}{l}\text { Adjusted Annual } \\
\text { Heating COP [-] }\end{array}$ & $\begin{array}{l}\text { Total System } \\
\text { Performance [-] }\end{array}$ & $\begin{array}{l}\text { Annual Cooling COP } \\
{[-]}\end{array}$ \\
\hline Toronto & 1.83 & 0.55 & 3.99 \\
\hline Montreal & 1.63 & 0.61 & 3.99 \\
\hline Edmonton & 1.38 & 0.72 & 3.99 \\
\hline Note: \\
\hline \multicolumn{4}{|l}{ Values for Adjusted Annual Heating COP were calculated based on PHIUS (2013c) } \\
\hline
\end{tabular}

\section{Calculation of Heat Pump System Performance}

PHIUS (2013c) recommended the use of a spreadsheet calculator by DOE (2012) to determine the adjusted heating season performance factor (HSPF) for the heat pump unit. Calculation of the adjusted HSPF was conducted using heating 99\% dry bulb winter design temperatures from Manual J (ACCA, 2011), according to the equation in the spreadsheet calculator from DOE (2012). IP units were necessarily used due to the empirical factors present in the equation (Equation A - 11). Once the adjusted COP was obtained, calculations were conducted using SI units (Equation A $-12)$.

$$
\begin{gathered}
H S P F_{(A d j)}=H S P F_{(I V)}-\left(H S P F _ { ( I V ) } \left(0.1041+\left(-0.008862 \times T_{d}\right)+\right.\right. \\
\left.\left.\left(-0.0001153 \times T_{d}{ }^{2}\right)+H S P F_{I V} \times 0.02817\right)\right)
\end{gathered}
$$

Where: 
$H S P F_{(A d j)}=$ Climate adjusted heat pump HSPF, BTU/Wh

$H S P F_{(I V)}=$ heating season performance factor of heat pump for climate, BTU/Wh

$T_{d}=$ winter design temperature (heating 99\% dry bulb) obtained from Manual $\mathrm{J},{ }^{\circ} \mathrm{F}$

The adjusted COP was then calculated according to the method described by PHIUS, (2013c).

$$
\operatorname{COP}_{(A d j)}=H S P F_{(A d j)} \cdot\left(\frac{1055 \mathrm{~J} / \mathrm{BTU}}{3600 \mathrm{~J} / \mathrm{Wh}}\right)
$$

Where:

$\operatorname{COP}_{(\operatorname{Adj})}=$ climate adjusted annual COP of heat pump

WUFI Passive requires the additional input of the Total System Performance ratio (TSPR), which according to WUFI Passive, is defined as the inverse of the adjusted COP (Equation A - 10).

\section{Electric Resistance Heating (Case B)}

Backup heating must be supplied to cover the peak-heating load for a portion of the year in certain climates, when outdoor air temperatures are below the lowtemperature cutout point of the heat pump system. The fraction of backup electric resistance heating summarized in Table A - 17 is calculated in the following section.

Table A - 17 Summary of Backup Electric Heating Required for Each Location

\begin{tabular}{|l|l|}
\hline Test Location & Fraction of Backup Heat Required $\left(\boldsymbol{\delta}_{\boldsymbol{b u}}\right)$ \\
\hline Toronto & 0.00 \\
\hline Montreal & 0.03 \\
\hline Edmonton & 0.12 \\
\hline
\end{tabular}

\section{Calculation of Backup Heating Fraction}

Air-to-air mini split heat pump units are limited in their ability to operate at temperatures below a certain threshold due to the decreasing efficiency in heat transfer with decreasing outdoor air temperature. This threshold is known as the low temperature cutout point of the heat pump unit, which varies depending on the make and model. A backup heating system is required for climates experiencing wintertime temperatures below the heating equipment cutout point. The backup system must be capable of meeting the entire space heating demand for periods 
when the heat pump is unable to operate. The bin method, described by Wemhöner and Afjei (2003), was used to determine the fraction of backup heating required in each location.

For the purpose of this study, electric resistance baseboard heaters were selected to provide backup heating, representing a low cost solution typically used in Passive House designs. It was assumed that the set point of the electric baseboard backup heating system was the same as the heat pump set point of $21^{\circ} \mathrm{C}$. For all locations and scenarios it was assumed that the heat pump would be able to cover the entire building heating load down to the low temperature cutout point. Therefore, backup heating was only used to provide all heating below the low temperature cutout point of the heat pump and not used to cover part of the load above that point. This is called alternate backup operation mode.

\section{STEP 1}

A total of 7 uniformly spaced bins, representing temperature intervals of $8.3^{\circ} \mathrm{C}$ were selected for a total temperature range of $-37.5^{\circ} \mathrm{C}$ to $20.8^{\circ} \mathrm{C}$. The middle of each bin temperature interval was used to calculate an equipment operation point based on test data from the heat pump manufacturer. Intervals were selected based on the manufacturer test data covering two operating points at $8.3^{\circ} \mathrm{C}$ and $-8.3^{\circ} \mathrm{C}$. The manufacturer stated low temperature cutout point of the heat pump is $-20^{\circ} \mathrm{C}$ (drybulb).

The manufacturer data included values for maximum rated heating capacity and energy consumption at each temperature test point, which allowed for calculation of the equipment $\mathrm{COP}$ at the two operating points of $8.3^{\circ} \mathrm{C}$ and $-8.3^{\circ} \mathrm{C}$ using the following equation from Wemhöner and Afjei (2003):

$$
C O P=\frac{\phi_{h p}}{W_{i n}}
$$

Where:

$C O P=$ heat pump coefficient of performance

$\phi_{h p}=$ heat pump heating capacity, $\mathrm{W}$

$W_{\text {in }}=$ heat pump electricity consumption, $\mathrm{W}$

COP values for the remaining operating points were then determined by using linear extrapolation (Equation A - 14). Results of research conducted by Safa (2012) investigating the in-situ performance of air source heat pumps in Toronto indicated 
an approximately linear relationship between COP and heating operating temperature. Therefore, linear extrapolation was deemed suitable for approximating the $\mathrm{COP}$ of the heat pump system at operating temperatures down to the low temperature cutout point.

Results of the extrapolation are summarized in Table A - 18. The COP at the lowtemperature cutout point is indicated in the table as LTC.

$$
\mathrm{COP}_{T, n}=\mathrm{COP}_{2}-\frac{\left(\mathrm{COP}_{2}-\mathrm{COP}_{1}\right) \cdot\left(T_{2}-T_{n}\right)}{\left(T_{2}-T_{1}\right)}
$$

Where:

$\mathrm{COP}_{T, n}=$ heat pump coefficient of performance at temperature $\mathrm{n}$

$\mathrm{COP}_{1}$ = heat pump coefficient of performance from manufacturer data point 1

$\mathrm{COP}_{2}=$ heat pump coefficient of performance from manufacturer data point 2

$T_{n}=$ temperature of operating point to be extrapolated, ${ }^{\circ} \mathrm{C}$

$T_{1}=$ temperature from manufacturer data point $1,-8.3^{\circ} \mathrm{C}$

$T_{2}=$ temperature from manufacturer data point $2,8.3^{\circ} \mathrm{C}$

Table A - 18 Extrapolated Heat Pump COP Data

\begin{tabular}{|c|c|c|c|}
\hline $\begin{array}{l}\text { Operation } \\
\text { Point }\end{array}$ & Bin Range & $\begin{array}{l}\text { Dry-bulb Temperature } \\
\left({ }^{\circ} \mathrm{C}\right)\end{array}$ & $\begin{array}{l}\text { Heat Pump COP } \\
(-)\end{array}$ \\
\hline 1 & 1 to 2 & 16.67 & 3.82 \\
\hline 2 & 2 to 3 & 8.33 & 3.44 \\
\hline 3 & 3 to 4 & 0.00 & 3.06 \\
\hline 4 & 4 to 5 & -8.33 & 2.68 \\
\hline 5 & 5 to 6 & -16.67 & 2.3 \\
\hline LTC & & -20 & 2.15 \\
\hline & 6 to 7 & -25.00 & 1.92 \\
\hline & 7 to 8 & -33.33 & 1.54 \\
\hline \multicolumn{4}{|c|}{$\begin{array}{l}\text { Note: } \\
\text { Values in bold denote manufacturer data points } \\
\text { LTC denotes values at equipment low-temperature cutout point } \\
\text { All other values were calculated from linear extrapolation }\end{array}$} \\
\hline
\end{tabular}

\section{STEP 2}

In order to conduct the bin analysis, weather data files representing each location were obtained from Environment Canada in .csv delimited format. Files selected were part of Environment Canada's Canadian Weather year for Energy Calculation (CWEC) data sets, with each file containing a full years worth of hourly weather data 
statistically formulated to represent 30 years of data similar to typical meteorological year (TMY) data (Environment Canada, 2008).

Since the CWEC data was provided in a delimited format, all meteorological observations for each hour were represented as a string of text and numbers in a single column. In order to extract the dry bulb temperature value, the data had to be split into separate columns through the use of excel functions.

\section{STEP 3}

For each location, a set of temperature bins was created, ranging from the minimum dry bulb temperature up to and including $18^{\circ} \mathrm{C}$. Each bin was selected to represent a $1^{\circ} \mathrm{C}$ temperature increment, and was assigned an excel column. An excel "if" statement was used to mark a column with a "1" if the bin temperature was greater than the hourly dry bulb temperature. Each column was summed to calculate the cumulative number of bin hours at each temperature increment, representing the number of hours per year at or below that temperature.

\section{STEP 4}

The number of heating degree hours were then determined for each bin temperature:

$$
H D H\left(T_{i}\right)=\left(T_{\text {base }}-T_{a m b, i}\right) \cdot\left(n_{\text {hours }, i}\right)
$$

Where:

$H D H\left(T_{i}\right)=$ number of heating degree hours for temperature bin $i, \mathrm{Kh} / \mathrm{yr}$

$T_{\text {base }}=$ base temperature below which heating is required, $18^{\circ} \mathrm{C}$

$T_{a m b, i}=$ ambient air temperature of bin $i,{ }^{\circ} \mathrm{C}$

$n_{\text {hours }, i}=$ number of hours in the 1-year TMY file for temperature $=T_{a m b, i}$, hours

\section{STEP 5}

The cumulative number of heating degree hours up to the low temperature cutout point were determined by summing all heating degree hours for each temperature bin below the low temperature cutout point of the heat pump (Equation $A-16$ ).

$$
H D H_{L T C}=\sum_{i=1}^{T_{L T C, i}}\left(T_{\text {base }}-T_{a m b}\right) \cdot\left(n_{\text {hours }, i}\right)
$$

Where:

$H D H_{L T C}=$ number of heating degree hours up to the low temperature cutout point of the heat pump (from $\mathrm{T}_{\min }$ to $\mathrm{T}_{\mathrm{LTC}}$ ), $\mathrm{Kh} / \mathrm{yr}$ 
$T_{L T C, i}=$ low temperature cutout point of heat pump, $-20^{\circ} \mathrm{C}$

The total number of heating degree hours for the location was calculated via equation $\mathrm{A}-17$.

$$
H D H_{\text {total }}=\sum_{i=1}^{T_{\text {max }, i}}\left(T_{\text {base }}-T_{\text {amb }}\right) \cdot\left(n_{\text {hours }, i}\right)
$$

Where:

$H D H_{\text {total }}=$ total number of heating degree hours, $\mathrm{Kh} / \mathrm{yr}$

\section{STEP 6}

The fraction of backup heat required was calculated using Equation A - 18 (Wemhöner \& Afjei, 2003):

$$
\delta_{b u}=\frac{H D H_{L T C}}{H D H_{t o t a l}}
$$

Where:

$\delta_{b u}=$ Fraction of backup heating required

$H D H_{\text {total }}=$ total number of heating degree hours

The fraction of heating covered by the heat pump was calculated using the following equation:

$$
\delta_{h p}=1-\delta_{b u}
$$

Where:

$\delta_{h p}=$ Fraction of heating supplied by heat pump 


\section{Appendix B}

Athena Impact Estimator Embodied GWP and Operating GWP Modeling

Procedure 


\section{Athena Impact Estimator Embodied GWP and Operating GWP Modeling Procedure}

This section provides a detailed description of the parameters input into Athena Impact Estimator to create the reference building envelope assemblies and includes the assumptions made and their associated justification.

\section{General Inputs (for all assemblies)}

1. Reference building envelope wall, roof, and slab assemblies were created based on the envelope section in Figure 4-2 (Section 4.3).

2. Toronto and Montreal were selected as the "Project Location" to represent 2 of the 3 locations modeled. Since no data was available for Edmonton, Calgary was selected as a proxy for the third location.

3. A "Building Life Expectancy" of 60 years was selected based on literature by Himpe et al. (2013), Bowick (2011) and NRCan (2007).

4. Values for "Operating Energy Consumption", including electricity and natural gas usage were calculated from WUFI Passive modelling results for each envelope assembly iteration.

5. After all parameters were input, data output was obtained using the "Reports" for "All Summary Measures".

\section{Wall Assembly Model}

The following general inputs were used to model the reference building walls. A "Custom Wall" type assembly was added to the main project to represent the interior structural wall.

For the "Custom Wall" Tab:

- A "Length" value for entering into the Athena wall assembly was derived from the WUFI Passive calculated surface area and dividing this value by the single-storey height of $2.82 \mathrm{~m}$ (Athena "Height" = $2.82 \mathrm{~m}$ ) 
- A "Wood Stud" 38 x 140 mm, 600 mm o.c. load bearing wall was added with plywood sheathing to represent the interior side structural wall of the reference building design

For the "Opening" tab:

- "Number of Windows" = 17 (from the reference building design) and the "Total Window Area $\left(\mathrm{m}^{2}\right)$ " $=20.6$ (from WUFI Passive). Although windows were not modeled for the assemblies, the rough opening area was input to account for additional framing that would occur at these junctions.

- "Frame Type" = none (windows were not considered)

- "Glazing Type" = none (windows were not considered)

- "Number of Doors" = 1 (from reference building design) "Door Type" = none (doors were not considered)

For wall assembly iterations 4 through 9, a second "Custom Wall" type assembly was added to the main project to represent the exterior non-structural wall. For the "Custom Wall" Tab:

- A "Length" value for entering into the Athena wall assembly was derived from the WUFI Passive calculated surface area and dividing this value by the single-storey height of $2.82 \mathrm{~m}$ (Athena "Height" = $2.82 \mathrm{~m}$ )

- A "Wood Stud" 38 x 64 mm, 600 mm o.c. non-load bearing wall was added with plywood sheathing to represent the exterior sheathing

For the "Opening" tab:

- "Number of Windows" = 17 (from the reference building design) and the "Total Window Area (m2)" = 20.6 (from WUFI Passive) Although windows were not modeled for the assemblies, the rough opening area was input to account for additional exterior wall framing that would occur at these junctions.

- "Frame Type" = none (windows were not considered) 
- "Glazing Type" = none (windows were not considered)

- "Number of Doors" = 1 (from reference building design) "Door Type" = none (doors were not considered)

For the "Envelope" tab, only the required thickness of the exterior wall insulation was input, since the other wall components were accounted for in the interior wall assembly.

\section{Wall Material Take-offs}

Wall material take-offs were used to generate inputs to model each wall assembly iteration. Wall assembly insulation iterations 0 and 1 represent un-insulated (airfilled) and insulated $139 \mathrm{~mm}(2 " \mathrm{x} 6 ")$ interior structural stud cavities. Iteration 2 represents a double stud wall system, where a stud insulation cavity wall is added to the exterior of the first wall with a thickness of $89 \mathrm{~mm}$. Iteration 3 represents an increased exterior stud insulation cavity of $139 \mathrm{~mm}$ deep. The thickness of wall insulation for iterations 4 through 9 was determined by the insulation cavity space provided by the exterior TJI wall, which was increased in thickness sequentially from 241 in iteration 4 to 302, 356, 406, 457, and $508 \mathrm{~mm}$ for iterations 5, 6, 7, 8, and 9, respectively. The total insulation depth is reported in Table C - 1 .

Table C - 1 Wall Assembly Iteration Total Insulation Depth

\begin{tabular}{|c|c|c|c|c|}
\hline Iteration Number & \begin{tabular}{|l}
$\begin{array}{l}\text { Stud Cavity } \\
\text { Insulation Depth } \\
(\mathrm{mm})\end{array}$ \\
\end{tabular} & $\begin{array}{l}\text { Double Stud Cavity } \\
\text { Insulation Depth } \\
(\mathrm{mm})\end{array}$ & $\begin{array}{l}\text { TJI Insulation } \\
\text { Depth } \\
(\mathrm{mm}) \\
\end{array}$ & $\begin{array}{l}\text { Total Insulation } \\
\text { Depth } \\
(\mathrm{mm}) \\
\end{array}$ \\
\hline Reference Building Wall & 140 & 0 & 25 & 394 \\
\hline 0 & 0 & 0 & & 0 \\
\hline 1 & 140 & 0 & & 140 \\
\hline 2 & 140 & 89 & & 229 \\
\hline 3 & 140 & 140 & & 280 \\
\hline 4 & 140 & 0 & 24 & 381 \\
\hline 5 & 140 & 0 & 30 & 442 \\
\hline 6 & 140 & 0 & 35 & 496 \\
\hline 7 & 140 & 0 & 40 & 546 \\
\hline 8 & 140 & 0 & 45 & 597 \\
\hline 9 & 140 & 0 & 50 & 648 \\
\hline
\end{tabular}


Structural wall materials modeled for iterations 0 and 1 are summarized in Table C 2 .

Table C - 2 Wall Assembly Structural Materials Modeled for Iterations 0 and 1

\begin{tabular}{|l|l|l|}
\hline $\begin{array}{l}\text { Layer (from Interior to } \\
\text { Exterior) }\end{array}$ & $\begin{array}{l}\text { Layer Thickness } \\
\text { (mm) }\end{array}$ & Notes \\
\hline Latex paint & 0 & \\
\hline Gypsum (drywall) & 12.5 & \\
\hline Structural Stud Cavity & 140 & $609 \mathrm{~mm}$ O.C. \\
\hline Plywood Sheathing & 15 & \\
\hline Spun Bonded Poly Olefin & 0 & \\
\hline Vertical Strapping & 38 & \\
\hline Pine Board Siding & NA & \\
\hline
\end{tabular}

Structural wall materials modeled for iterations 2 and 3 are summarized in Table C 3.

Table C - 3 Wall Assembly Structural Materials Modeled for Iterations 2 and 3

\begin{tabular}{|l|l|l|}
\hline $\begin{array}{l}\text { Layer (from Interior to } \\
\text { Exterior) }\end{array}$ & $\begin{array}{l}\text { Layer Thickness } \\
(\mathrm{mm})\end{array}$ & Notes \\
\hline Latex paint & 0 & \\
\hline Gypsum (drywall) & 12.5 & \\
\hline Structural Stud Cavity & 140 & $609 \mathrm{~mm}$ O.C. \\
\hline Plywood Sheathing & 15 & \\
\hline Structural Stud Cavity & Varies & $609 \mathrm{~mm}$ O.C. \\
\hline Plywood Sheathing & 15 & \\
\hline Spun Bonded Poly Olefin & 0 & \\
\hline Vertical Strapping & 38 & \\
\hline Pine Board Siding & NA & \\
\hline
\end{tabular}

Structural wall materials modeled for iterations 4 through 9 are summarized in Table C - 4 . 
Table C - 4 Wall Assembly Structural Materials Modeled for Iterations 4 through 9

\begin{tabular}{|l|l|l|}
\hline $\begin{array}{l}\text { Layer (from Interior to } \\
\text { Exterior) }\end{array}$ & $\begin{array}{l}\text { Layer Thickness } \\
(\mathbf{m m})\end{array}$ & Notes \\
\hline Latex paint & 0 & \\
\hline Gypsum (drywall) & 12.5 & \\
\hline Structural Stud Cavity & 140 & $609 \mathrm{~mm}$ O.C. \\
\hline Plywood Sheathing & 15 & \\
\hline TJI Cavity & Varies & $609 \mathrm{~mm}$ O.C. \\
\hline Plywood Sheathing & 15 & \\
\hline Spun Bonded Poly Olefin & 0 & \\
\hline Vertical Strapping & 38 & \\
\hline Pine Board Siding & NA & \\
\hline
\end{tabular}

\section{Calculations for Additional Wall Inputs}

\section{Interior Stud Walls}

For all cases, the interior structural stud walls remained the same. For the interior stud walls, the following calculation was used to determine the total amount of wood used in the structure. Under the "Custom Wall" tab, the "Length (m)" represents the total length of the walls if they were stretched out on a single story. Two times the perimeter length of the slab was used for this value. This takes into account the additional wood used for the top and bottom plates of the wall. The "Height (m)" represented the single-story height of the wall.

Therefore:

Length $(\mathrm{m})=2 \mathrm{x}$ Perimeter

Height $(\mathrm{m})=$ Single Story Height

\section{Exterior Double-stud Insulation Cavities}

For the exterior walls, iterations 2 and 3 are a double stud configuration, with the studs running the full two-storey height.

Therefore:

Length $(\mathrm{m})=$ Perimeter

Height $(\mathrm{m})=2 \mathrm{x}$ Single Story Height 


\section{Exterior TJI Insulation Cavities}

TJI walls are not standard in Athena IE, therefore necessitating input of TJI wall features using a combination of "Wood Stud" Assembly Components and the "Extra Basic Material" function. Material take-offs for the TJI walls are conducted as follows:

\section{TJI Model Part 1 - Using Available Assembly Components from "Custom Wall" tool}

All TJI sizes modelled use the same flange sizes ( $89 \mathrm{~mm} \times 38 \mathrm{~mm})$. Additionally, the "Custom Wall" tool is able to model this size of lumber as a "Wood Stud" component. Therefore, two additional "Custom Wall" assemblies will be added to model the interior and exterior facing TJI flanges.

\section{TJI Model Part 2 - Using Extra Basic Material tool}

The "Extra Basic Material" tool is used to account for the material usage of the following components:

The exterior plywood sheathing The OSB used for webs of the TJIs Insulation in TJI cavity wall The exterior SBPO/air barrier The exterior cladding (pine wood shiplap siding) The take-offs for these aforementioned materials are determined in the following sections.

\section{Extra Basic Material \#1 - Exterior Plywood Sheathing}

TJI Wall Top and Bottom Plates and Exterior Wall Sheathing were constructed of plywood. Athena accepts input of plywood using the area of plywood, assuming that each sheet is $9 \mathrm{~mm}$ thick. Athena also assumes a standard material wastage for offcuts of 5\%. The total area of plywood used for the top and bottom plates was calculated using Equations $\mathrm{C}-1$ and $\mathrm{C}-2$. Inputs for Athena IE, along with intermediate calculation results are summarized in Table $\mathrm{C}-5$. 


$$
A_{\text {top }}=A_{\text {bottom }}=\left(W_{\text {sw }}+t_{T J I}\right) \times t_{T J I}
$$

Where:

$A_{\text {top }}=$ top plate area, $\mathrm{m}^{2}$

$A_{\text {bottom }}=$ bottom plate area, $\mathrm{m}^{2}$

$W_{s w}=$ exterior width of the interior stud wall, $\mathrm{m}$

$t_{T J I}=$ thickness or depth of the TJI, $\mathrm{m}$

$$
A_{\text {Total Top \& Bottom Plates }}=\left(A_{\text {top }}+A_{\text {bottom }}\right) \times 4 \text { walls }
$$

Where:

$A_{\text {Total Top \& Bottom Plates }}=$ total area of top and bottom plates, $\mathrm{m}^{2}$

Therefore $A_{\text {Total }}$ is a function of the depth of the truss

The area of plywood used for exterior wall sheathing is calculated as follows:

$$
A_{\text {Exterior Sheathing }}=\left(W_{s w}+t_{T J I}\right) \times H_{\text {wall }}
$$

Where:

$A_{\text {Exterior Sheathing }}=$ area of exterior wall sheathing, $\mathrm{m}^{2}$

$H_{\text {wall }}=$ full 2-story wall height, $\mathrm{m}$

The total area of plywood used for exterior sheathing and top and bottom plates:

$$
A_{\text {Total Plywood }}=A_{\text {Total Top \& Bottom Plates }}+A_{\text {Exterior Sheathing }}
$$

Where:

$\mathrm{A}_{\text {Total Plywood }}=$ total area of plywood used, $\mathrm{m}^{2}$ 
Finally, since the reference building specification lists $15 \mathrm{~mm}$ plywood and only $9 \mathrm{~mm}$ thick plywood was found in the Athena IE database, a thickness correction had to be applied to model the correct quantity of plywood.

$$
A_{\text {Total } 9 \mathrm{~mm} \text { Plywood }}=A_{\text {Total Plywood }} \times(15 \mathrm{~mm} / 9 \mathrm{~mm}) \quad(\mathrm{C}-5)
$$

Where:

$A_{\text {Total } 9 \mathrm{~mm} \text { Plywood }}=$ total area of plywood equivalent to $15 \mathrm{~mm}, \mathrm{~m}^{2}$

Table C - 5 Summary of Wall Extra Basic Material \# 1 Inputs

\begin{tabular}{|c|c|c|c|c|c|}
\hline \multirow[b]{2}{*}{ Iteration Number } & \multirow[b]{2}{*}{$\begin{array}{l}\text { Total TJI Cavity } \\
\text { Depth, } t_{\text {TJI }}(\mathrm{mm})\end{array}$} & \multicolumn{4}{|c|}{ Extra Basic Material \#1 - 9 mm Plywood } \\
\hline & & $\begin{array}{l}\text { Total Area of Wall } \\
\text { Plywood Top \& } \\
\text { Bottom Plates, } A_{\text {Total Top }} \\
\text { \& Bottom Plates }\left(\mathrm{m}^{2}\right)\end{array}$ & $\begin{array}{l}\text { of Exterior } \\
\text { Sheathing, } \\
A_{\text {Total Exterior }} \\
\text { Sheathing }\left(\mathrm{m}^{2}\right)\end{array}$ & $\begin{array}{l}\text { Total } 15 \mathrm{~mm} \\
\text { Plywood Area, } \\
\text { A }_{\text {Total Plywood }}\left(\mathrm{m}^{2}\right)\end{array}$ & $\begin{array}{l}\text { Total } 9 \mathrm{~mm} \\
\text { Plywood Area, } \\
A_{\text {Total } 9 \mathrm{~mm} \text { Plywood }} \\
\left(\mathrm{m}^{2}\right)\end{array}$ \\
\hline Reference Building & 254 & 19.07 & 188 & 442 & 736 \\
\hline 4 & 241 & 18.09 & 187 & 429 & 715 \\
\hline 5 & 302 & 22.76 & 189 & 490 & 817 \\
\hline 6 & 356 & 26.98 & 190 & 545 & 909 \\
\hline 7 & 406 & 31.00 & 191 & 597 & 995 \\
\hline 8 & 457 & 35.07 & 192 & 649 & 1082 \\
\hline 9 & 508 & 39.17 & 193 & 701 & 1168 \\
\hline
\end{tabular}

\section{Extra Basic Material \#2 - TJI Web (OSB)}

Athena accepts input of OSB using the area of OSB, assuming that each sheet is $9 \mathrm{~mm}$ thick. Athena also assumes a standard material wastage for off-cuts of 5\%. TJI properties were obtained from Weyerhaeuser (2014) and are summarized in Table C - 6. Final inputs for each assembly iteration along with the intermediate calculation results are summarized in Table C - 7.

The area of OSB used is calculated as follows:

$$
A_{\text {web }}=H_{\text {wall }} X d_{\text {web }}
$$


Where:

$A_{\text {web }}=$ area of $1 \mathrm{TJI}$ web, $\mathrm{m}^{2}$

$H_{\text {wall }}=$ height of the wall, $\mathrm{m}$

$d_{w e b}=$ depth of the TJI web (from flange to flange), $\mathrm{m}$

Table C - 6 Summary of TJI Properties

\begin{tabular}{|c|c|c|c|c|c|}
\hline \multirow[b]{2}{*}{ Iteration Number } & \multirow{2}{*}{\begin{tabular}{|l|} 
TJI Total \\
Depth $(\mathrm{mm})$
\end{tabular}} & \multicolumn{2}{|c|}{ Flange Properties } & \multicolumn{2}{|c|}{ Web Properties } \\
\hline & & Width (mm) & Height (mm) & Thickness (mm) & Web Height $(\mathrm{mm})$ \\
\hline Reference Building & 254 & 89 & 38 & 11 & 178 \\
\hline 4 & 241 & 89 & 38 & 11 & 165 \\
\hline 5 & 302 & 89 & 38 & 11 & 225 \\
\hline$\overline{6}$ & 356 & 89 & 38 & 11 & 279 \\
\hline 7 & 406 & 89 & 38 & 11 & 330 \\
\hline 8 & 457 & 89 & 38 & 11 & 381 \\
\hline 9 & 508 & 89 & 38 & 11 & 432 \\
\hline
\end{tabular}

The depth of the TJI web was calculated as follows:

$$
d_{w e b}=t_{T J I}-2 \times d_{\text {flange }}
$$

Where:

$d_{\text {flange }}=$ flange depth, $\mathrm{m}$

$t_{T J I}=$ thickness or depth of the TJI, $\mathrm{m}$

The total surface area of the TJI webs was determined using the following equation:

$$
A_{\text {Total Surface of Webs }}=A_{\text {web }} \times \text { Total \# TJIS }
$$

Where:

$A_{\text {Total Surface of Webs }}=$ total surface area of TJI webs, $\mathrm{m}$ 
Finally, since the specified TJIs have $11 \mathrm{~mm}$ OSB webs and only 9mm thick OSB was found in the Athena IE database, a thickness correction had to be applied to model the correct quantity of OSB.

$$
A_{\text {Total } 9 \mathrm{~mm} \mathrm{OSB}}=A_{\text {Total webs }} \times(11 \mathrm{~mm} / 9 \mathrm{~mm})
$$

Where:

$A_{\text {Total } 9 \mathrm{~mm} \text { OSB }}=$ total area of OSB equivalent to $11 \mathrm{~mm}, \mathrm{~m}^{2}$

Table C - 7 Summary of Extra Basic Material \#2 Inputs

\begin{tabular}{|c|c|c|c|}
\hline \multirow[b]{2}{*}{ Iteration Number } & \multirow[b]{2}{*}{$\begin{array}{l}\text { Total TJI Cavity } \\
\text { Depth, } t_{\mathrm{T} I}(\mathrm{~mm})\end{array}$} & \multicolumn{2}{|c|}{ Extra Basic Material \#2 - 9mm OSB } \\
\hline & & $\begin{array}{l}\text { Total TJI Web } 11 \\
\mathrm{~mm} \text { OSB Area, } A_{\text {Total }} \\
\text { Surface of Webs }\left(\mathrm{m}^{2}\right)\end{array}$ & $\begin{array}{l}\text { Athena Input for Total } \\
\text { TJI Web } 9 \mathrm{~mm} \text { OSB } \\
\text { Area, } A_{\text {Total } 9 \mathrm{~mm} \text { osB }}\left(\mathrm{m}^{2}\right)\end{array}$ \\
\hline Reference Building & 254 & 56.96 & 69.62 \\
\hline 4 & 241 & 52.90 & 64.65 \\
\hline 5 & 302 & 72.20 & 88.24 \\
\hline 6 & 356 & 89.47 & 109.35 \\
\hline 7 & 406 & 105.73 & 129.22 \\
\hline 8 & 457 & 121.98 & 149.09 \\
\hline 9 & 508 & 138.24 & 168.96 \\
\hline
\end{tabular}

\section{Extra Basic Material \#3 - TJI Cavity Insulation}

Athena accepts input of insulation using the area of the exterior walls, and assumes a thickness of $25 \mathrm{~mm}$. Athena also assumes a standard material wastage factor of $5 \%$, which cannot be changed. The total volume of insulation required for filling the TJI cavity was calculated, and then divided by $25 \mathrm{~mm}$ to obtain the factor suitable for input into Athena IE. The inputs for each assembly iteration and intermediate calculation steps are summarized in Table C - 8 and Table C - 9.

The total TJI Cross Sectional Area was calculated using Equation C - 10 . 
Where:

$A_{\text {TJI }}=$ total cross sectional area of TJIs, $\mathrm{m}^{2}$

$A_{\text {Total webs }}=$ total TJI web area, $\mathrm{m}^{2}$

$A_{\text {Total flanges }}=$ total TJI flange area, $\mathrm{m}^{2}$

And

$$
A_{\text {Total flanges }}=W_{\text {flange }} \times d_{\text {flange }} \times 2 \times \text { Total \# TJIs }
$$

Where:

$W_{\text {flange }}=$ Flange width, $\mathrm{m}$

$d_{\text {flange }}=$ Flange depth, $\mathrm{m}$

Total cross-sectional (plan view) area of the exterior walls was determined using Equation C - 12 .

$$
A_{\text {Exterior Walls }}=\left(W_{s W}+t_{T J I}\right) \times t_{T J I} \times 4
$$

Where:

$A_{\text {Exterior Walls }}=$ area of exterior walls, $\mathrm{m}^{2}$

$W_{s w}=$ exterior width of the interior stud wall, $\mathrm{m}$

$t_{T J I}=$ thickness or depth of the TJI, m

The total plan view area of the insulation cavity was calculated by subtracting the area taken up by the TJIs from the total exterior wall area.

$$
A_{\text {Insulation Cavity }}=A_{\text {Exterior Walls }}-A_{\text {TJI }}
$$

Where: 
$A_{\text {Insulation Cavity }}=$ area of insulation cavity, $\mathrm{m}^{2}$

$$
V_{\text {Insulation }}=H_{\text {wall }} \times A_{\text {Insulation } \text { Cavity }}
$$

Where:

$V_{\text {Insulation }}=$ volume of insulation in TJI cavity, $\mathrm{mm}^{3}$

$H_{\text {wall }}=$ height of the wall, $\mathrm{m}$

Finally, the total area of $25 \mathrm{~mm}$ thick insulation required to fill the insulation cavity was calculated for input into Athena IE.

$$
A_{\text {insulation per } 25 \mathrm{~mm}}=V_{\text {Insulation }} / 25 \mathrm{~mm}
$$

Where:

$A_{\text {insulation per } 25 \mathrm{~mm}}=$ area of insulation per $25 \mathrm{~mm}$ thickness, $\mathrm{m}^{2}$

\begin{tabular}{|c|c|c|c|c|c|}
\hline \multirow[b]{2}{*}{ Iteration Number } & \multirow[b]{2}{*}{ 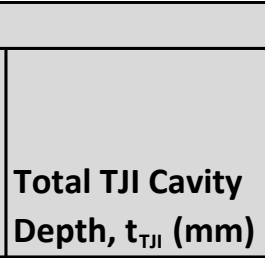 } & \multicolumn{4}{|c|}{ Extra Basic Material \#3 - Cavity Insulation } \\
\hline & & $\begin{array}{l}\text { Total CS Area } \\
\text { of TJI Flanges, } \\
A_{\text {Total Flanges }}\left(\mathrm{m}^{2}\right)\end{array}$ & $\begin{array}{l}\text { Total CS Area } \\
\text { of TJI Webs, } \\
\text { A }_{\text {Total Webs }}\left(\mathrm{m}^{2}\right)\end{array}$ & \begin{tabular}{|l|} 
Total CS \\
Area of TJIs, \\
$A_{T I I}\left(\mathrm{~m}^{2}\right)$
\end{tabular} & $\begin{array}{l}\text { Total CS Area of } \\
\text { Exterior Walls, } \\
A_{\text {Exterior Walls }}\left(\mathrm{m}^{2}\right)\end{array}$ \\
\hline Reference Building & 254 & 0.43 & 0.43 & 0.87 & 9.53 \\
\hline 4 & 241 & 0.43 & 0.40 & 0.84 & 9.05 \\
\hline 5 & 302 & 0.43 & 0.55 & 0.98 & 11.38 \\
\hline 6 & 356 & 0.43 & 0.68 & 1.11 & 13.49 \\
\hline 7 & 406 & 0.43 & 0.81 & 1.24 & 15.50 \\
\hline 8 & 457 & 0.43 & 0.93 & 1.36 & 17.53 \\
\hline 9 & 508 & 0.43 & 1.05 & 1.49 & 19.58 \\
\hline
\end{tabular}

\section{Table C - 8 Summary of Extra Basic Material \#3 Inputs}


Table C - 9 Summary of Extra Basic Material \#3 Inputs (Continued)

\begin{tabular}{|c|c|c|c|c|}
\hline \multirow[b]{2}{*}{ Iteration Number } & \multirow[b]{2}{*}{$\begin{array}{l}\text { Total TJI Cavity } \\
\text { Depth, } \mathrm{t}_{\mathrm{TJ}}(\mathrm{mm})\end{array}$} & \multicolumn{3}{|c|}{ Extra Basic Material \#3 - Cavity Insulation (Continued) } \\
\hline & & $\begin{array}{l}\text { Total CS Area of } \\
\text { Insulation Cavity, } \\
A_{\text {Insulation Cavity }}\left(\mathrm{m}^{2}\right)\end{array}$ & $\begin{array}{l}\text { Total Volume of } \\
\text { Blown Cellulose, } \\
V_{\text {Insulation }}\left(\mathrm{m}^{3}\right)\end{array}$ & $\begin{array}{l}\text { Athena Input for } \\
\text { Blown Cellulose, } \\
\text { A }_{\text {Insulation per } 25 \mathrm{~mm}} \\
\left(\mathrm{~m}^{2} \text { per } 25 \mathrm{~mm}\right)\end{array}$ \\
\hline Reference Building & 254 & 8.67 & 43.34 & 1734 \\
\hline 4 & 241 & 8.21 & 41.05 & 1642 \\
\hline 5 & 302 & 10.40 & 51.98 & 2079 \\
\hline 6 & 356 & 12.38 & 61.89 & 2476 \\
\hline 7 & 406 & 14.26 & 71.32 & 2853 \\
\hline 8 & 457 & 16.17 & 80.85 & 3234 \\
\hline 9 & 508 & 18.10 & 90.49 & 3620 \\
\hline \multicolumn{5}{|c|}{ Note: Values in bold denote inputs for Athena IE } \\
\hline
\end{tabular}

\section{Extra Basic Material \#4 - Exterior SBPO/Air Barrier}

The Spun Bonded Poly Olefin weather barrier (or air barrier in Athena IE) is calculated as follows. Athena IE accepts input of "Air Barrier" in terms of surface area of the material $\left(\mathrm{m}^{2}\right)$. Athena IE adds a default of $2 \%$ as a construction waste factor for air barrier material. Since the air barrier is wrapped around the outside of the exterior plywood sheathing, the surface area of the air barrier material is the same as the exterior sheathing previously calculated in Equation $\mathrm{C}-3$. Extra basic material input data is summarized in Table C - 10.

Table C - 10 Summary of Extra Basic Material \#4 Inputs

\begin{tabular}{|r|r|l|}
\hline Iteration Number & $\begin{array}{l}\text { Total TJI Cavity } \\
\text { Depth, } \mathbf{t}_{\mathrm{TI}}(\mathbf{m m})\end{array}$ & $\begin{array}{l}\text { Total Area of Air } \\
\text { Barrier }\left(\mathbf{m}^{\mathbf{2}} \mathbf{)}\right.\end{array}$ \\
\hline Reference Building & 254 & $\mathbf{1 8 8}$ \\
\hline 4 & 241 & $\mathbf{1 8 7}$ \\
\hline 5 & 302 & $\mathbf{1 8 9}$ \\
\hline 6 & 356 & $\mathbf{1 9 0}$ \\
\hline 7 & 406 & $\mathbf{1 9 1}$ \\
\hline 8 & 457 & $\mathbf{1 9 2}$ \\
\hline 9 & 508 & \\
\hline Note: Values in bold denote inputs for Athena IE \\
\hline
\end{tabular}




\section{Exterior Vertical Strapping for Cladding}

Exterior vertical strapping forms the ventilation cavity and the support structure for the cladding. This layer can be modelled in Athena IE by using one of the "Available Assembly Components" of the "Custom Wall" tool. A wood stud assembly is added and the following attributes of the vertical strapping are added:

Wall Type $=$ Non Load Bearing

Stud Type $=$ Kiln-dried

Sheathing Type $=$ None

Stud Thickness $=38 \times 64 \mathrm{~mm}$

Stud Spacing $=600$ o.c.

Since the thickness of the wall changes as the exterior wall cavity space is increased (Cases 2 through 9), the length of the wall upon which the strapping is fastened is also increased. The height of the exterior surface of the wall does not change; therefore the value entered for height is kept the same for all cases.

\section{For Cases 0 and 1:}

The structural stud wall rests on the slab and is assumed to be flush with the edge. The vertical strapping is fastened to the exterior plywood sheathing. Therefore the length of the wall upon which the vertical strapping is applied is equal to the perimeter length of the slab.

Length $(\mathrm{m})=$ Perimeter

\section{For Cases 2 through 9:}

The exterior sheathing layer is attached to a secondary (exterior) wall made up of either studs or TJIs. Therefore the length of the wall upon which the vertical strapping is applied is calculated using Equation C - 16. Calculation results for input into Athena IE are summarized in Table C - 11.

$$
L=\left(9.13+d_{\text {stud cavity }}\right) \times 4
$$


Where:

$L=$ wall length of vertical strapping contact, $\mathrm{m}$

$d_{\text {stud cavity }}=$ stud cavity thickness, $\mathrm{m}$

Table C - 11 Summary of Vertical Strapping Inputs

\begin{tabular}{|r|r|r|}
\hline Iteration Number & $\begin{array}{l}\text { Total Stud Cavity } \\
\text { Depth, } \mathbf{t}_{\text {stud Cavity }}(\mathbf{m m})\end{array}$ & Length $\mathbf{( m )}$ \\
\hline Reference Building & 254 & $\mathbf{3 7 . 5}$ \\
\hline 0 & 0 & $\mathbf{3 6 . 5}$ \\
\hline 1 & 0 & $\mathbf{3 6 . 5}$ \\
\hline 2 & 89 & $\mathbf{3 6 . 9}$ \\
\hline 3 & 140 & $\mathbf{3 7 . 1}$ \\
\hline 4 & 241 & $\mathbf{3 7 . 5}$ \\
\hline 5 & 302 & $\mathbf{3 7 . 7}$ \\
\hline 6 & 356 & $\mathbf{3 7 . 9}$ \\
\hline 7 & 406 & $\mathbf{3 8 . 1}$ \\
\hline 8 & 457 & $\mathbf{3 8 . 3}$ \\
\hline 9 & 508 & $\mathbf{3 8 . 6}$ \\
\hline
\end{tabular}

\section{Extra Basic Material \#5 - Exterior Cladding - Pine Wood Shiplap Cladding}

The pine wood shiplap cladding is calculated as follows. Athena IE accepts input of "Exterior Cladding" in terms of surface area of the material $\left(\mathrm{m}^{2}\right)$. Athena IE adds a default of $10 \%$ as a construction waste factor for siding. Since the exterior cladding is applied directly to the vertical strapping, the surface area of the exterior cladding material can be determined based on the exterior wall perimeter and height using Equation C - 17. Calculation results are summarized in Table C - 12 .

$$
A_{\text {cladding }}=H_{\text {wall }} *\left(9.13+d_{\text {stud cavity }}\right) \times 4
$$

Where:

$A_{\text {cladding }}=$ surface area of exterior cladding, $\mathrm{m}^{2}$ 
Table C - 12 Summary of Extra Basic Material \#5 Inputs

\begin{tabular}{|c|c|c|c|}
\hline Iteration Number & $\begin{array}{l}\text { Total Stud Cavity } \\
\text { Depth, } \mathrm{t}_{\text {stud Cavity }}(\mathrm{mm})\end{array}$ & Length $(\mathrm{m})$ & Area $\left(\mathrm{m}^{2}\right)$ \\
\hline Reference Building & 254 & 37.5 & 187.7 \\
\hline 0 & 0 & 36.5 & 182.6 \\
\hline 1 & 0 & 36.5 & 182.6 \\
\hline 2 & 89 & 36.9 & 184.4 \\
\hline 3 & 140 & 37.1 & 185.4 \\
\hline 4 & 241 & 37.5 & 187.4 \\
\hline 5 & 302 & 37.7 & 188.6 \\
\hline 6 & 356 & 37.9 & 189.7 \\
\hline 7 & 406 & 38.1 & 190.7 \\
\hline 8 & 457 & 38.3 & 191.7 \\
\hline 9 & 508 & 38.6 & 192.8 \\
\hline
\end{tabular}

\section{Attic (Roof) Assembly Model}

The following general inputs were used for all iterations when setting up the roof assembly model:

1. Span $(m)=4.56$ - determined by dividing the length of the wall by 2 to get the span of the roof joists $(9.13 \mathrm{~m} / 2=4.56 \mathrm{~m})$. The roof span entry for Athena determines the joist size needed.

2. Roof Width $(\mathrm{m})=18.28 \mathrm{~m}$ - obtained by dividing the footprint area of the building by the span.

3. Live Load $=2.4 \mathrm{kPa}$ for Iteration 1 and $3.6 \mathrm{kPa}$ for all other iterations - This is based on Athena's assumptions that solid wood $38 \times 89 \mathrm{~mm}$ joists spaced at $400 \mathrm{~mm}$ O.C. are used for a live load of $2.4 \mathrm{kPa}$, while $38 \times 140 \mathrm{~mm}$ joists spaced at $400 \mathrm{~mm}$ 0.C. are used for a live load of $3.6 \mathrm{kPa}$. The former scenario represents the typical roof load for residential applications, while the latter scenario was selected to match the design of the reference building and support the additional load of the insulation.

4. Decking Type $=$ Plywood

5. Decking Thickness $=15 \mathrm{~mm}$ 


\section{Roof Assembly Iterations}

Roof insulation thickness was first varied by changing the service cavity joist size from $38 \mathrm{~mm}$ x $89 \mathrm{~mm}(2 " \mathrm{x} 4 ")$ in iterations 0 and 1, to $38 \mathrm{~mm}$ x $140 \mathrm{~mm}$ (2"x6") in iteration 2. After the service cavity insulation was varied, additional insulation was added on top of a plywood air barrier layer in $100 \mathrm{~mm}$ (4 inch) increments for iterations 3 through 10. Iteration 0 consisted of an empty $38 \mathrm{~mm}$ x 89 mm (2"x4") service cavity, while the cavity was filled with insulation for iteration 1 . The service cavity was increased to $140 \mathrm{~mm}$ (2"x6") for iteration 2. Additional insulation beyond iteration 2 was added on top of the service cavity. All iteration insulation depths are summarized in Table C - 13.

Table C - 13 Summary of Roof Iteration Insulation Thickness

\begin{tabular}{|c|c|c|c|}
\hline Iteration Number & $\begin{array}{l}\text { Service Cavity } \\
\text { Insulation Depth } \\
(\mathrm{mm})\end{array}$ & $\begin{array}{l}\text { Attic Insulation Depth } \\
(\mathrm{mm})\end{array}$ & $\begin{array}{l}\text { Total Insulation } \\
\text { Depth } \\
(\mathrm{mm})\end{array}$ \\
\hline Reference Building Roof & 140 & 500 & 640 \\
\hline 0 & 0 & 0 & 0 \\
\hline 1 & 89 & 0 & 89 \\
\hline 2 & 140 & 0 & 140 \\
\hline 3 & 140 & 100 & 240 \\
\hline 4 & 140 & 200 & 340 \\
\hline 5 & 140 & 300 & 440 \\
\hline 6 & 140 & 400 & 540 \\
\hline 7 & 140 & 500 & 640 \\
\hline 8 & 140 & 600 & 740 \\
\hline 9 & 140 & 700 & 840 \\
\hline 10 & 140 & 800 & 940 \\
\hline
\end{tabular}

Materials defined for input into Athena for iterations 0 and 1 are summarized in Table C - 14. 
Table C - 14 Summary of Athena IE Roof Material Inputs for Iterations 0 and 1

\begin{tabular}{|c|c|c|}
\hline $\begin{array}{l}\text { Layer (from Interior to } \\
\text { Exterior) }\end{array}$ & $\begin{array}{l}\text { Layer Thickness } \\
(\mathrm{mm})\end{array}$ & Notes \\
\hline Gypsum (drywall) & 12.5 & \\
\hline Service cavity & 89 & 406 mm (16") O.C. \\
\hline Plywood Sheathing & 15 & \\
\hline Exterior Plywood Sheathing & 15 & \\
\hline Metal Roof Cladding & $30 \mathrm{Ga}$ & \\
\hline
\end{tabular}

Materials defined for input into Athena for iteration 2 is summarized in Table C - 15 .

Table C - 15 Summary of Athena IE Roof Material Inputs for Iteration 2

\begin{tabular}{|c|c|c|}
\hline $\begin{array}{l}\text { Layer (from Interior to } \\
\text { Exterior) }\end{array}$ & $\begin{array}{l}\text { Layer Thickness } \\
(\mathrm{mm})\end{array}$ & Notes \\
\hline Gypsum (drywall) & 12.5 & \\
\hline Insulated service cavity & 140 & 406 mm (16") O.C. \\
\hline Plywood Sheathing & 15 & \\
\hline Exterior Plywood Sheathing & 15 & \\
\hline Metal Roof Cladding & $30 \mathrm{Ga}$ & \\
\hline
\end{tabular}

Materials defined for input into Athena for iterations 3 through 10 are summarized in Table C - 16.

Table C - 16 Summary of Athena IE Roof Material Inputs for Iterations 3 through 10

\begin{tabular}{|c|c|c|}
\hline $\begin{array}{l}\text { Layer (from Interior to } \\
\text { Exterior) }\end{array}$ & $\begin{array}{l}\text { Layer Thickness } \\
(\mathrm{mm})\end{array}$ & Notes \\
\hline Gypsum (drywall) & 12.5 & \\
\hline Insulated service cavity & 140 & 406 mm (16") O.C. \\
\hline Plywood Sheathing & 15 & \\
\hline Additional Attic Insulation & Varies & from 100 to $800 \mathrm{~mm}$ \\
\hline Exterior Plywood Sheathing & 15 & \\
\hline Metal Roof Cladding & $30 \mathrm{Ga}$ & \\
\hline
\end{tabular}




\section{Roof Extra Basic Material \#1 - Air Control Layer}

In order to include the plywood air barrier as specified in the reference building design, an extra basic material had to be defined. Athena accepts input of plywood using the area of plywood, assuming that each sheet is $9 \mathrm{~mm}$ thick. Athena also assumes a standard material wastage for off-cuts of $5 \%$. The total area of plywood used for the top and bottom plates is calculated as follows:

$$
A_{\text {plywood }}=A_{\text {building footprint }}=L \times W
$$

Where:

$\mathrm{L}=$ building length, $\mathrm{m}$

$\mathrm{W}=$ building width, $\mathrm{m}$

$\mathrm{A}_{\text {plywood }}=$ total area of plywood air control layer, $\mathrm{m}^{2}$

Since only $9 \mathrm{~mm}$ thick plywood was available in the material database the following conversion was done to correct the quantity of plywood to reflect the reference building specified $15 \mathrm{~mm}$ thick plywood. The conversion was conducted according to Equation $C-5$, previously defined for wall assembly calculations.

\section{Slab Assembly Model}

The following general data was input to create the reference building slab assembly model.

1. A "Foundations" type assembly was added to the main project

2. "User Defined Concrete Mix Design Library" - "Add" record for "Components"

a. Process- Added "Ready Mix Concrete Plant Process" from library. This process has a "Unit Quantity Contribution" of 1.0 for each unit of material

b. Material - Added “Concrete $30 \mathrm{MPa}$ (flyash 25\%)" from library. Used since CMHC (2000) lists using a minimum of $25 \mathrm{MPa}$ concrete for slab on grade construction, with $30 \mathrm{MPa}$ being recommended. 
3. Assembly Details:

a. Length: $8.408 \mathrm{~m}$, Width: $8.408 \mathrm{~m}$, based on Area of slab $=70.69 \mathrm{~m}^{2}-$ Calculated from Reference building design using AutoCAD (slab extends under 2x6's \& air barrier sheathing)

b. Thickness: $200 \mathrm{~mm}$, Concrete: $30 \mathrm{MPa}$, Concrete Flyash \%: 25\%

4. Envelope Components:
a. Polyethylene 6 mil
b. Insulation type (EPS or XPS)
c. Insulation thickness (varied according to insulation level)

\section{Slab Assembly Iterations}

Insulation iterations for the slab assembly were defined based on $25.4 \mathrm{~mm}$ increments up to $102 \mathrm{~mm}$, after which the iterations increase in $50.8 \mathrm{~mm}$ increments. Table C - 17 summarizes the slab insulation thicknesses analyzed. Table C - 17 Summary of Slab Iteration Insulation Thicknesses

\begin{tabular}{|c|c|}
\hline Iteration Number & $\begin{array}{l}\text { Underslab } \\
\text { Insulation Depth } \\
(\mathrm{mm})\end{array}$ \\
\hline Reference Building Slab & 254 \\
\hline 0 & 0 \\
\hline 1 & 25 \\
\hline 2 & 51 \\
\hline 3 & 76 \\
\hline 4 & 102 \\
\hline 5 & 152 \\
\hline 6 & 203 \\
\hline 7 & 254 \\
\hline 8 & 305 \\
\hline 9 & 356 \\
\hline 10 & 406 \\
\hline
\end{tabular}

Slab iteration 0 was defined as an un-insulated slab assembly, with Athena IE material inputs summarized in Table C - 18. 
Table C - 18 Summary of Material Inputs for Slab Assembly Iteration 0

\begin{tabular}{|l|l|l|}
\hline Layer (from Interior to Exterior) & $\begin{array}{l}\text { Layer Thickness } \\
(\mathrm{mm})\end{array}$ & Notes \\
\hline Concrete & 200 & \\
\hline 6-mil Polyethylene Vapour Barrier & - & No thickness required \\
\hline EPS Insulation & 0 & No insulation \\
\hline
\end{tabular}

Athena IE material inputs for slab iterations 1 through 10 are summarized in Table C - 19.

Table C - 19 Summary of Material Inputs for Slab Assembly Iterations 1 through 10

\begin{tabular}{|l|l|l|}
\hline Layer (from Interior to Exterior) & $\begin{array}{l}\text { Layer Thickness } \\
(\mathbf{m m})\end{array}$ & Notes \\
\hline Concrete & 200 & \\
\hline 6-mil Polyethylene Vapour Barrier & - & No thickness required \\
\hline EPS Insulation & varies & from $25.4 \mathrm{~mm}$ to $406 \mathrm{~mm}$ \\
\hline
\end{tabular}


Appendix C

Building Assembly Sections 
Assembly (Id.4): Reference Building Walls

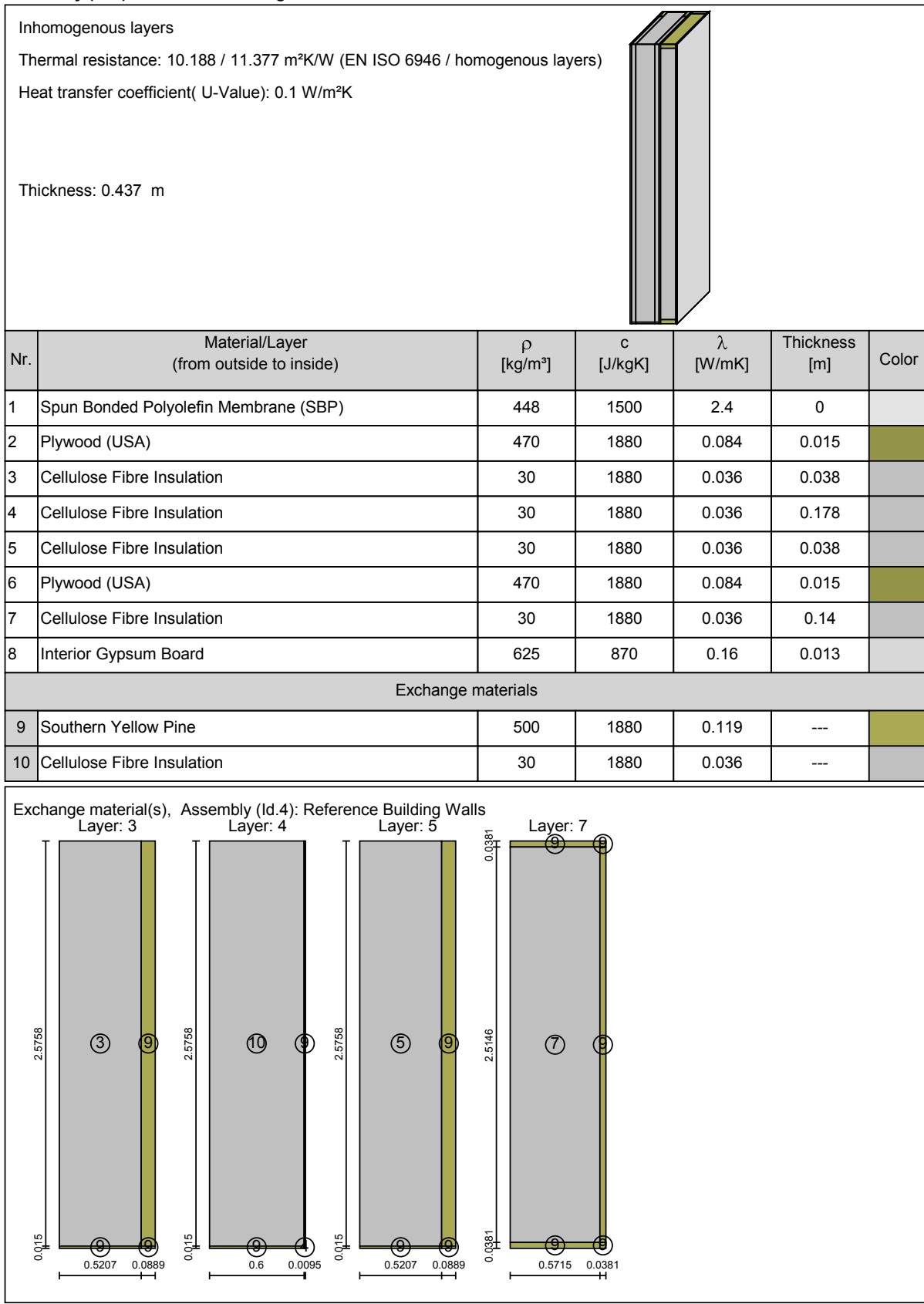




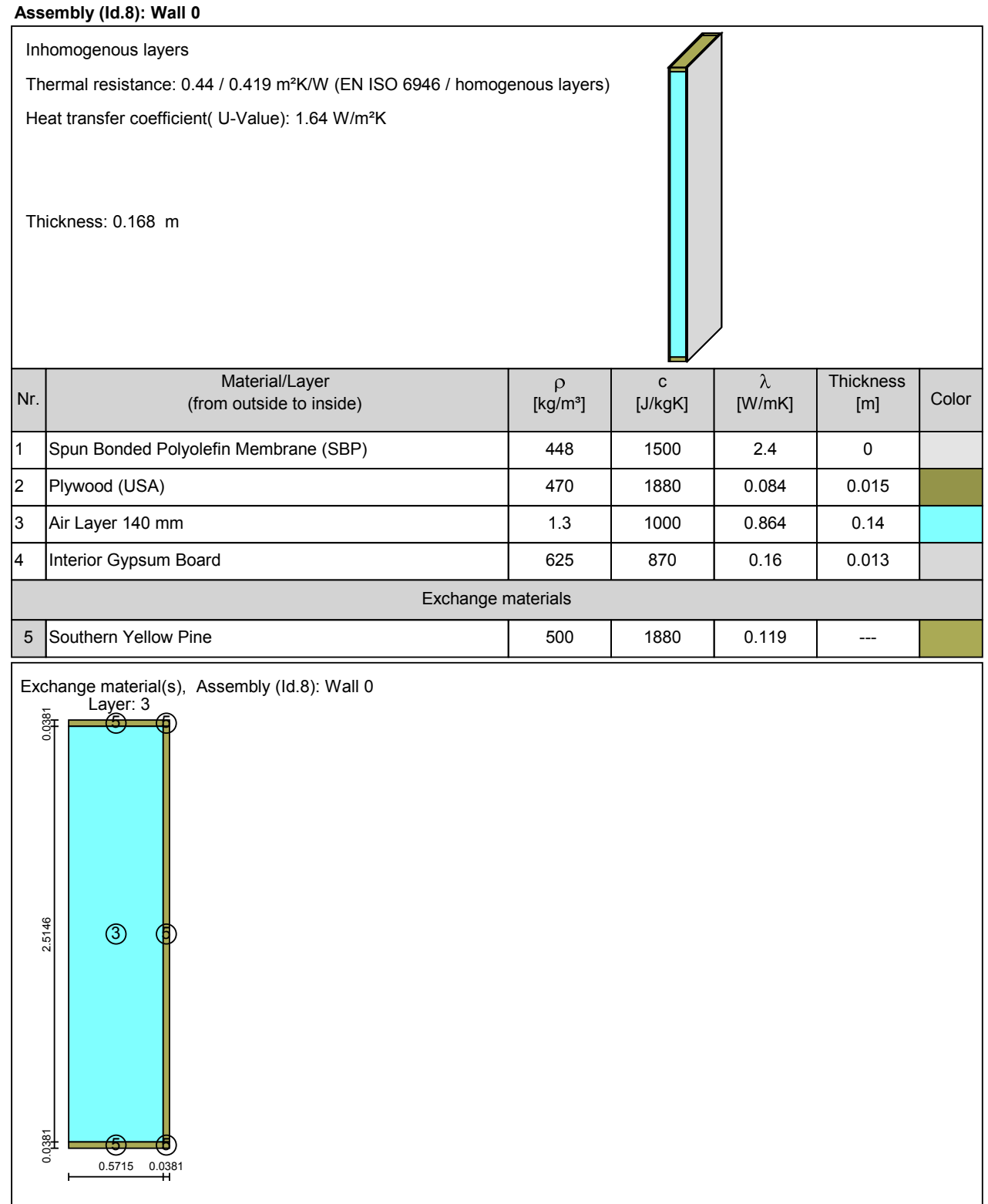


Assembly (Id.17): Wall 1

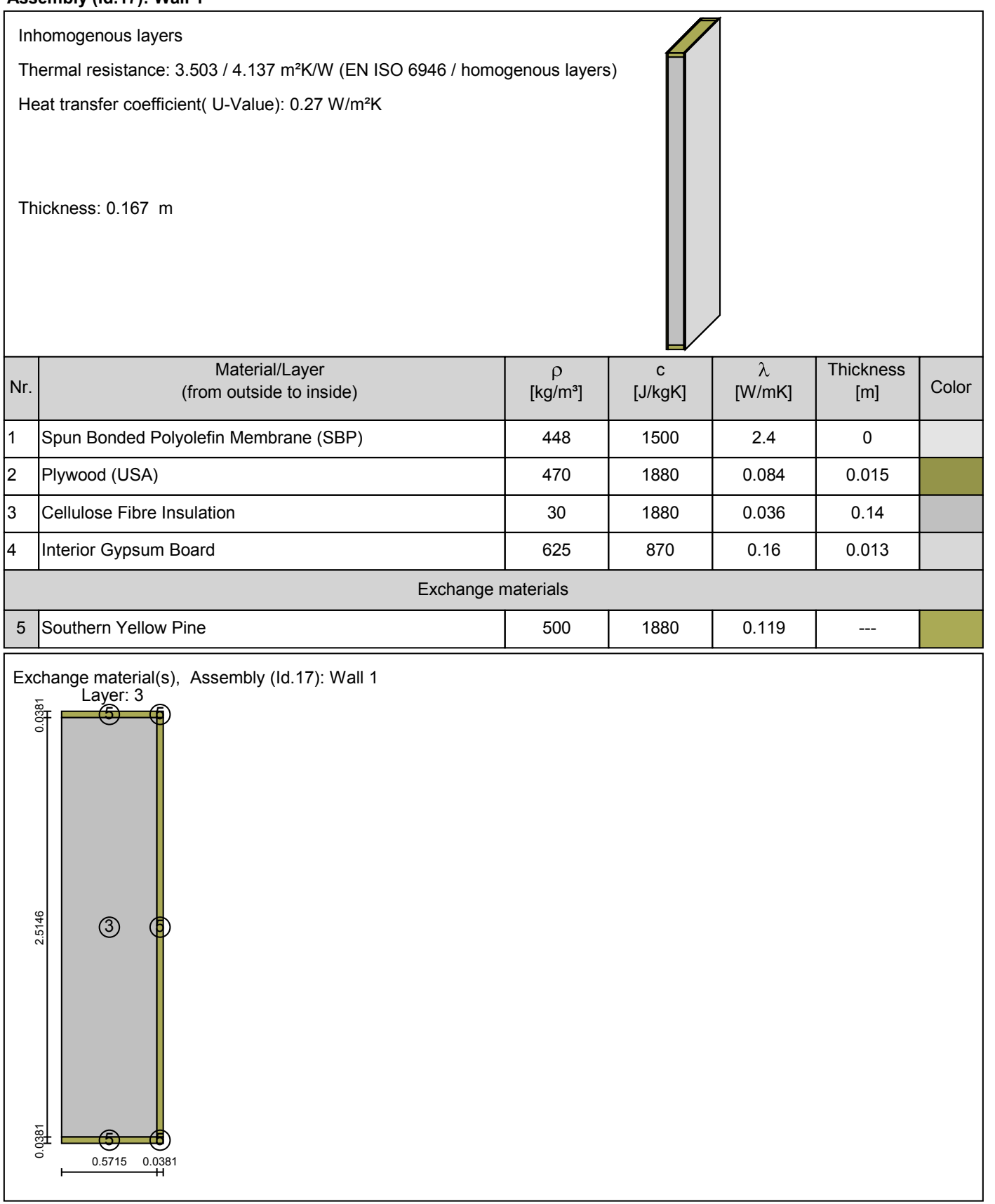




\section{Assembly (Id.19): Wall 2}

\section{Inhomogenous layers}

Thermal resistance: 5.75 / $6.788 \mathrm{~m}^{2} \mathrm{~K} / \mathrm{W}$ (EN ISO 6946 / homogenous layers)

Heat transfer coefficient( U-Value): $0.17 \mathrm{~W} / \mathrm{m}^{2} \mathrm{~K}$

Thickness: $0.271 \mathrm{~m}$

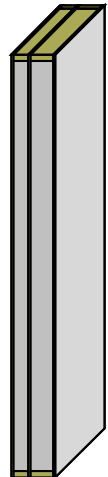

\begin{tabular}{|c|c|c|c|c|c|c|}
\hline $\mathrm{Nr}$. & $\begin{array}{c}\text { Material/Layer } \\
\text { (from outside to inside) }\end{array}$ & $\begin{array}{c}\rho \\
{\left[\mathrm{kg} / \mathrm{m}^{3}\right]}\end{array}$ & $\begin{array}{c}\mathrm{c} \\
{[\mathrm{J} / \mathrm{kgK}]}\end{array}$ & $\begin{array}{c}\lambda \\
{[\mathrm{W} / \mathrm{mK}]}\end{array}$ & $\begin{array}{c}\text { Thickness } \\
{[\mathrm{m}]}\end{array}$ & Color \\
\hline 1 & Spun Bonded Polyolefin Membrane (SBP) & 448 & 1500 & 2.4 & 0 & \\
\hline 2 & Plywood (USA) & 470 & 1880 & 0.084 & 0.015 & \\
\hline 3 & Cellulose Fibre Insulation & 30 & 1880 & 0.036 & 0.089 & \\
\hline 4 & Plywood (USA) & 470 & 1880 & 0.084 & 0.015 & \\
\hline 5 & Cellulose Fibre Insulation & 30 & 1880 & 0.036 & 0.14 & \\
\hline 6 & Interior Gypsum Board & 625 & 870 & 0.16 & 0.013 & \\
\hline \multicolumn{7}{|c|}{ Exchange materials } \\
\hline 7 & Southern Yellow Pine & 500 & 1880 & 0.119 & --- & \\
\hline
\end{tabular}

Exchange material(s), Assembly (Id.19): Wall 2

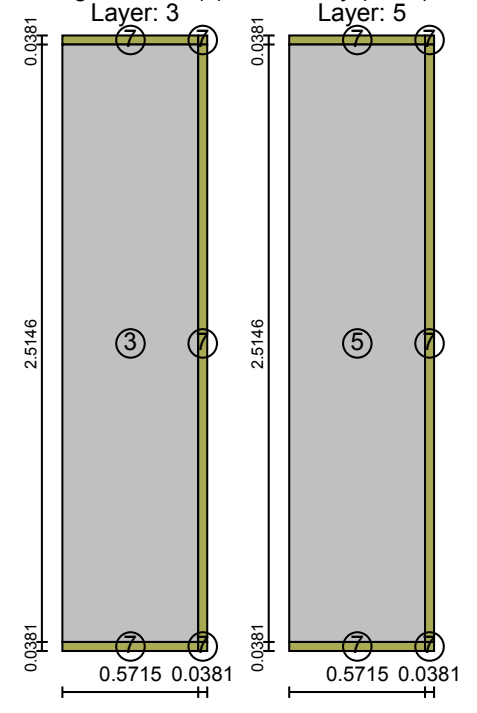




\section{Assembly (Id.18): Wall 3}

\section{Inhomogenous layers}

Thermal resistance: 6.918 / $8.196 \mathrm{~m}^{2} \mathrm{~K} / \mathrm{W}$ (EN ISO 6946 / homogenous layers)

Heat transfer coefficient( U-Value): $0.14 \mathrm{~W} / \mathrm{m}^{2} \mathrm{~K}$

Thickness: $0.322 \mathrm{~m}$

\begin{tabular}{|c|c|c|c|c|c|c|}
\hline Nr. & $\begin{array}{c}\text { Material/Layer } \\
\text { (from outside to inside) }\end{array}$ & $\begin{array}{c}\rho \\
{\left[\mathrm{kg} / \mathrm{m}^{3}\right]}\end{array}$ & $\begin{array}{c}\mathrm{c} \\
{[\mathrm{J} / \mathrm{kgK}]}\end{array}$ & $\begin{array}{c}\lambda \\
{[\mathrm{W} / \mathrm{mK}]}\end{array}$ & $\begin{array}{l}\text { Thickness } \\
{[\mathrm{m}]}\end{array}$ & Color \\
\hline 1 & Spun Bonded Polyolefin Membrane (SBP) & 448 & 1500 & 2.4 & 0 & \\
\hline 2 & Plywood (USA) & 470 & 1880 & 0.084 & 0.015 & \\
\hline 3 & Cellulose Fibre Insulation & 30 & 1880 & 0.036 & 0.14 & \\
\hline 4 & Plywood (USA) & 470 & 1880 & 0.084 & 0.015 & \\
\hline 5 & Cellulose Fibre Insulation & 30 & 1880 & 0.036 & 0.14 & \\
\hline 6 & Interior Gypsum Board & 625 & 870 & 0.16 & 0.013 & \\
\hline \multicolumn{7}{|c|}{ Exchange materials } \\
\hline 7 & Southern Yellow Pine & 500 & 1880 & 0.119 & --- & \\
\hline
\end{tabular}

Exchange material(s), Assembly (Id.18): Wall 3

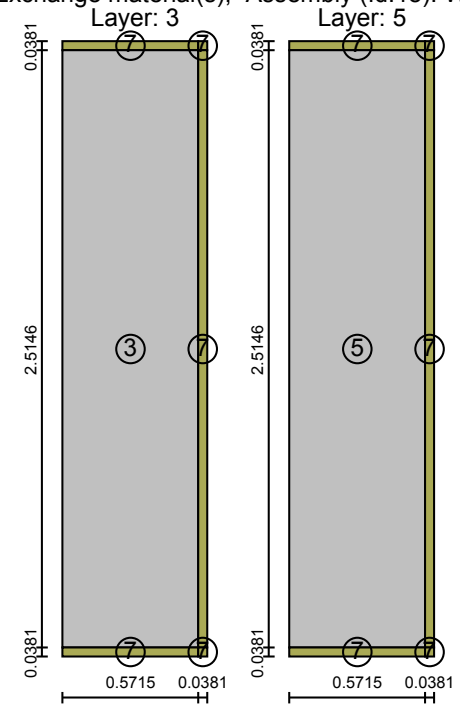




\section{Assembly (Id.20): Wall 4}

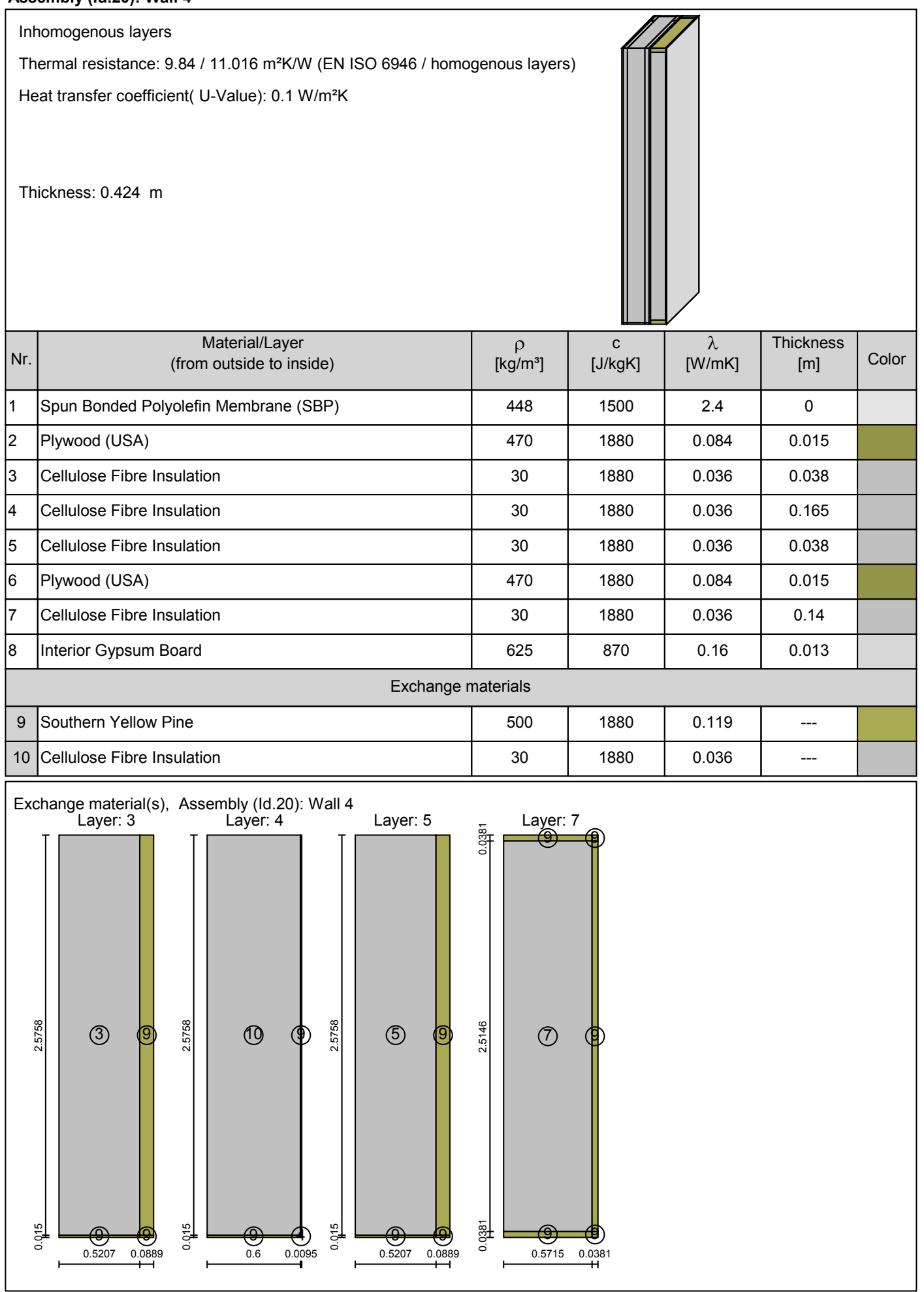




\section{Assembly (Id.21): Wall 5}

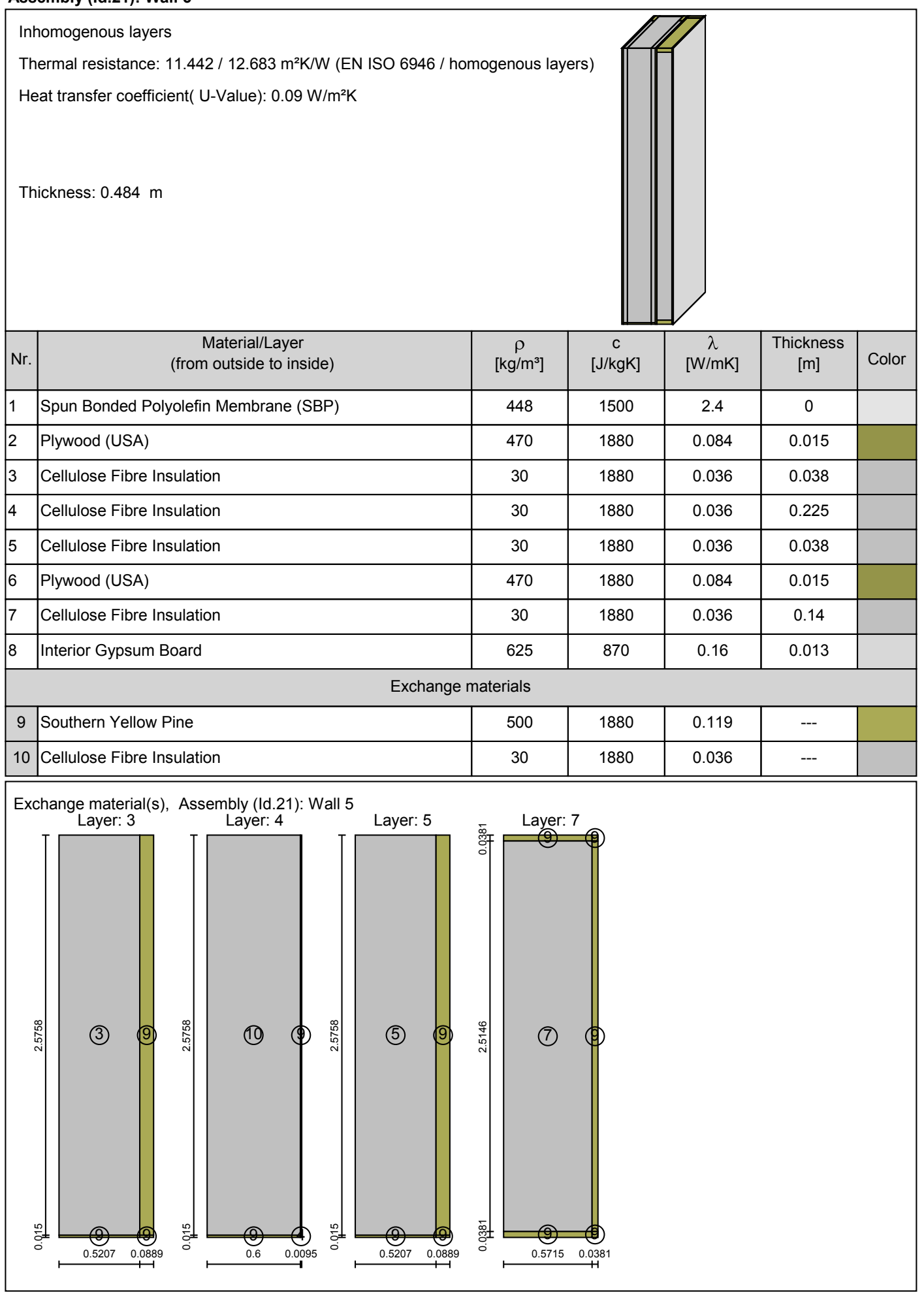




\section{Assembly (Id.22): Wall 6}

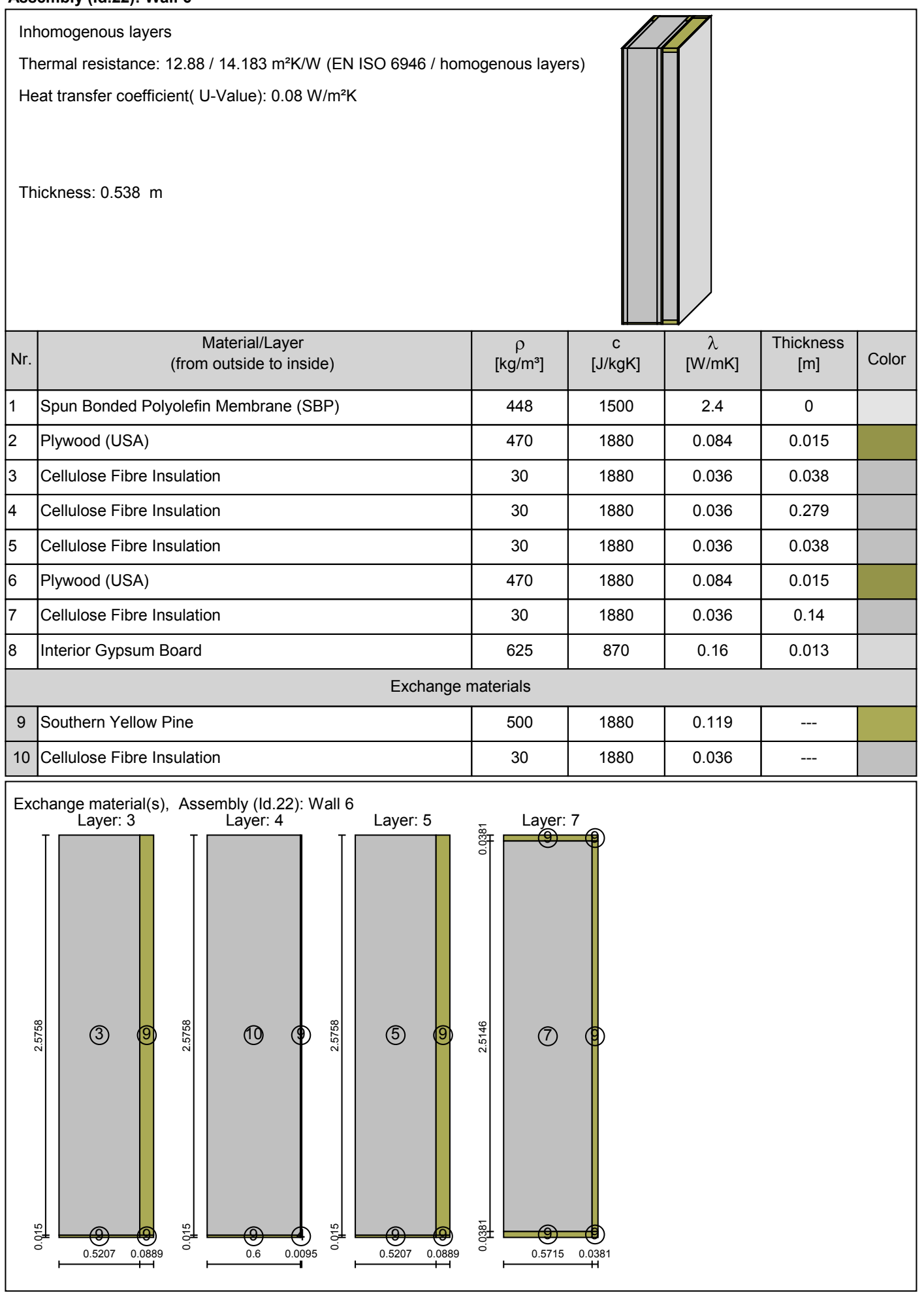




\section{Assembly (Id.23): Wall 7}

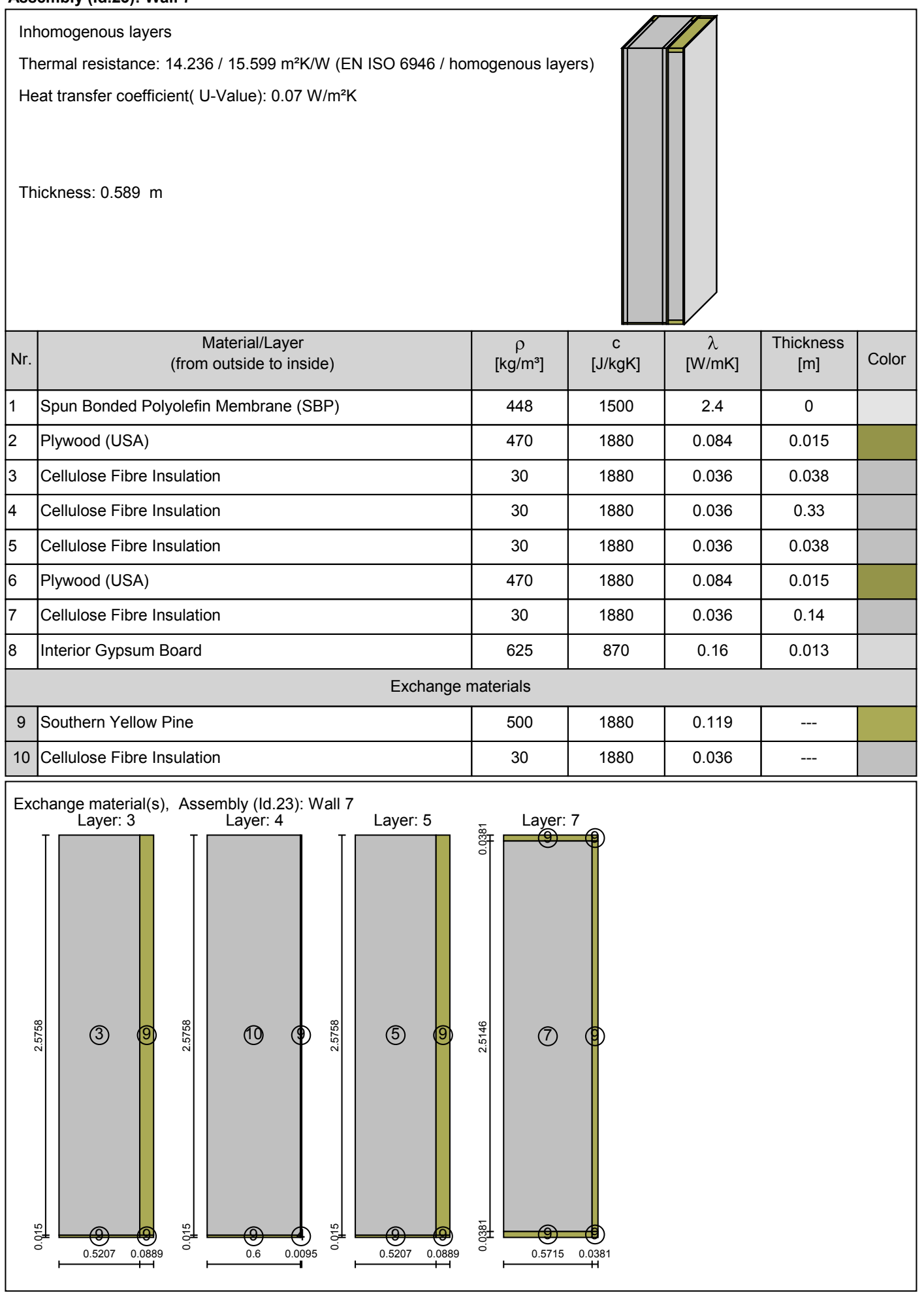




\section{Assembly (Id.24): Wall 8}

Inhomogenous layers

Thermal resistance: $15.591 / 17.016 \mathrm{~m}^{2} \mathrm{~K} / \mathrm{W}$ (EN ISO 6946 / homogenous layers)

Heat transfer coefficient( U-Value): $0.06 \mathrm{~W} / \mathrm{m}^{2} \mathrm{~K}$

Thickness: $0.64 \mathrm{~m}$

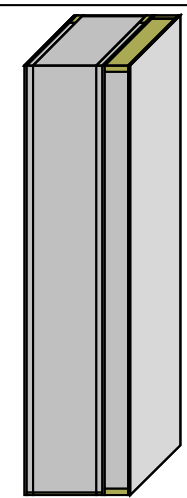

\begin{tabular}{|c|c|c|c|c|c|c|}
\hline $\mathrm{Nr}$. & $\begin{array}{c}\text { Material/Layer } \\
\text { (from outside to inside) }\end{array}$ & $\stackrel{\rho}{\left[\mathrm{kg} / \mathrm{m}^{3}\right]}$ & $\begin{array}{c}\mathrm{C} \\
{[\mathrm{J} / \mathrm{kgK}]}\end{array}$ & $\begin{array}{c}\lambda \\
{[\mathrm{W} / \mathrm{mK}]}\end{array}$ & $\begin{array}{c}\text { Thickness } \\
{[\mathrm{m}]}\end{array}$ & Color \\
\hline 1 & Spun Bonded Polyolefin Membrane (SBP) & 448 & 1500 & 2.4 & 0 & \\
\hline 2 & Plywood (USA) & 470 & 1880 & 0.084 & 0.015 & \\
\hline 3 & Cellulose Fibre Insulation & 30 & 1880 & 0.036 & 0.038 & \\
\hline 4 & Cellulose Fibre Insulation & 30 & 1880 & 0.036 & 0.381 & \\
\hline 5 & Cellulose Fibre Insulation & 30 & 1880 & 0.036 & 0.038 & \\
\hline 6 & Plywood (USA) & 470 & 1880 & 0.084 & 0.015 & \\
\hline 7 & Cellulose Fibre Insulation & 30 & 1880 & 0.036 & 0.14 & \\
\hline 8 & Interior Gypsum Board & 625 & 870 & 0.16 & 0.013 & \\
\hline \multicolumn{7}{|c|}{ Exchange materials } \\
\hline 9 & Southern Yellow Pine & 500 & 1880 & 0.119 & --- & \\
\hline 10 & Cellulose Fibre Insulation & 30 & 1880 & 0.036 & --- & \\
\hline
\end{tabular}

Exchange material(s), Assembly (Id.24): Wall 8

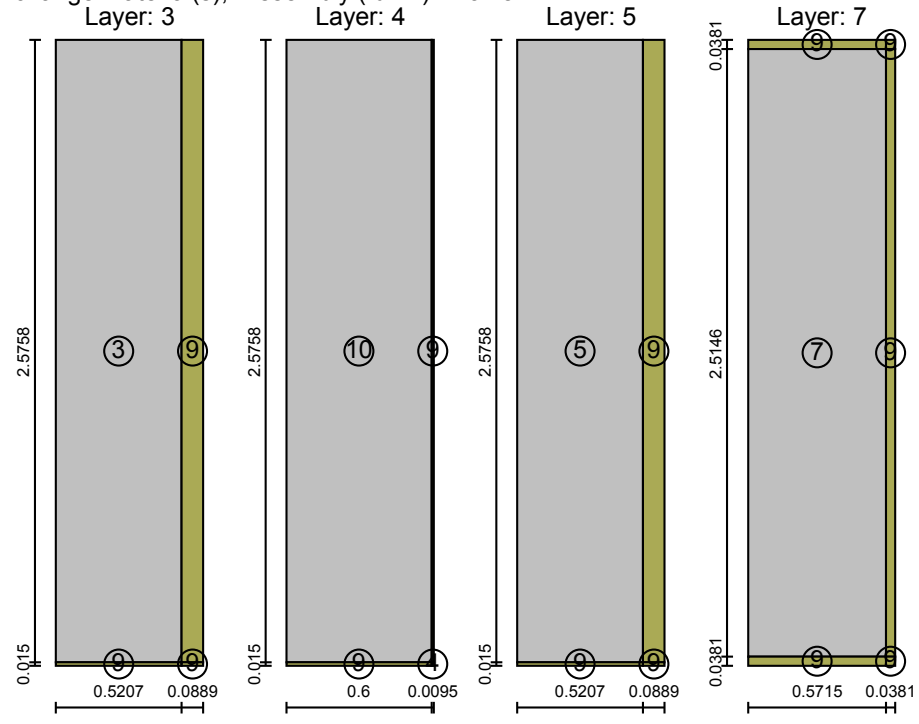




\section{Assembly (Id.25): Wall 9}

Inhomogenous layers

Thermal resistance: 16.946 / 18.433 m²K/W (EN ISO 6946 / homogenous layers)

Heat transfer coefficient( U-Value): $0.06 \mathrm{~W} / \mathrm{m}^{2} \mathrm{~K}$

Thickness: $0.691 \mathrm{~m}$

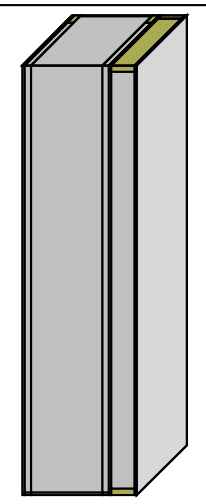

\begin{tabular}{|c|c|c|c|c|c|c|}
\hline $\mathrm{Nr}$. & $\begin{array}{c}\text { Material/Layer } \\
\text { (from outside to inside) }\end{array}$ & $\stackrel{\rho}{\left[\mathrm{kg} / \mathrm{m}^{3}\right]}$ & $\begin{array}{c}\mathrm{C} \\
{[\mathrm{J} / \mathrm{kgK}]}\end{array}$ & $\begin{array}{c}\lambda \\
{[\mathrm{W} / \mathrm{mK}]}\end{array}$ & $\begin{array}{c}\text { Thickness } \\
{[\mathrm{m}]}\end{array}$ & Color \\
\hline 1 & Spun Bonded Polyolefin Membrane (SBP) & 448 & 1500 & 2.4 & 0 & \\
\hline 2 & Plywood (USA) & 470 & 1880 & 0.084 & 0.015 & \\
\hline 3 & Cellulose Fibre Insulation & 30 & 1880 & 0.036 & 0.038 & \\
\hline 4 & Cellulose Fibre Insulation & 30 & 1880 & 0.036 & 0.432 & \\
\hline 5 & Cellulose Fibre Insulation & 30 & 1880 & 0.036 & 0.038 & \\
\hline 6 & Plywood (USA) & 470 & 1880 & 0.084 & 0.015 & \\
\hline 7 & Cellulose Fibre Insulation & 30 & 1880 & 0.036 & 0.14 & \\
\hline 8 & Interior Gypsum Board & 625 & 870 & 0.16 & 0.013 & \\
\hline \multicolumn{7}{|c|}{ Exchange materials } \\
\hline 9 & Southern Yellow Pine & 500 & 1880 & 0.119 & --- & \\
\hline 10 & Cellulose Fibre Insulation & 30 & 1880 & 0.036 & --- & \\
\hline
\end{tabular}

Exchange material(s), Assembly (Id.25): Wall 9

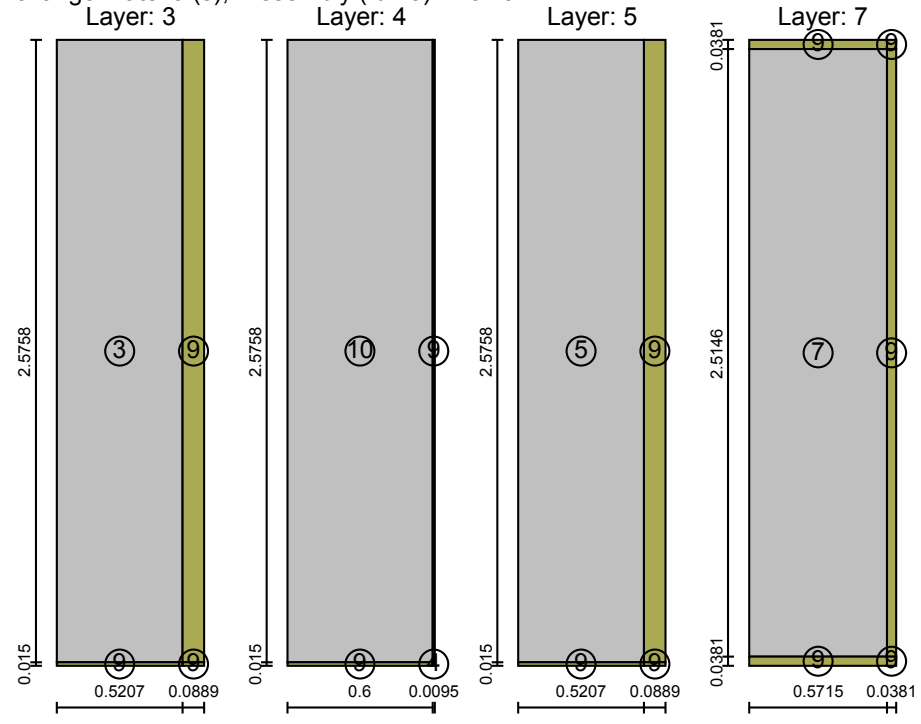


Assembly (Id.15): Reference Building Attic Ceiling

\section{Inhomogenous layers}

Thermal resistance: $17.518 / 18.007 \mathrm{~m}^{2} \mathrm{~K} / \mathrm{W}$ (EN ISO 6946 / homogenous layers)

Heat transfer coefficient( U-Value): $0.06 \mathrm{~W} / \mathrm{m}^{2} \mathrm{~K}$

Thickness: $0.667 \mathrm{~m}$

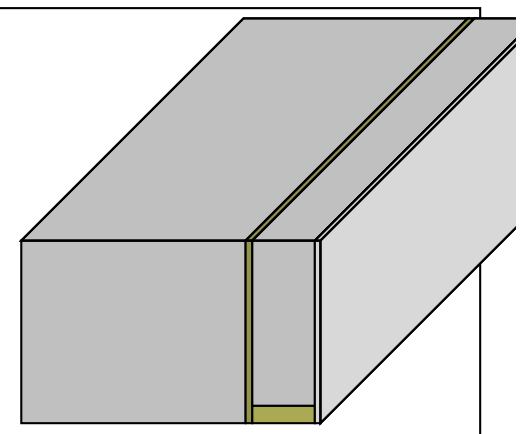

\begin{tabular}{|c|c|c|c|c|c|c|}
\hline $\mathrm{Nr}$. & $\begin{array}{c}\text { Material/Layer } \\
\text { (from outside to inside) }\end{array}$ & $\begin{array}{c}\rho \\
{\left[\mathrm{kg} / \mathrm{m}^{3}\right]}\end{array}$ & $\begin{array}{c}\mathrm{C} \\
{[\mathrm{J} / \mathrm{kgK}]}\end{array}$ & $\begin{array}{c}\lambda \\
{[\mathrm{W} / \mathrm{mK}]}\end{array}$ & $\begin{array}{c}\text { Thickness } \\
{[\mathrm{m}]}\end{array}$ & Color \\
\hline 1 & Cellulose Fibre Insulation & 30 & 1880 & 0.036 & 0.5 & \\
\hline 2 & Plywood (USA) & 470 & 1880 & 0.084 & 0.015 & \\
\hline 3 & Cellulose Fibre Insulation & 30 & 1880 & 0.036 & 0.139 & \\
\hline \multicolumn{7}{|c|}{ Exchange materials } \\
\hline 5 & Southern Yellow Pine & 500 & 1880 & 0.119 & --- & \\
\hline
\end{tabular}

Exchange material(s), Assembly (Id.15): Reference Building Attic Ceiling Layer: 3

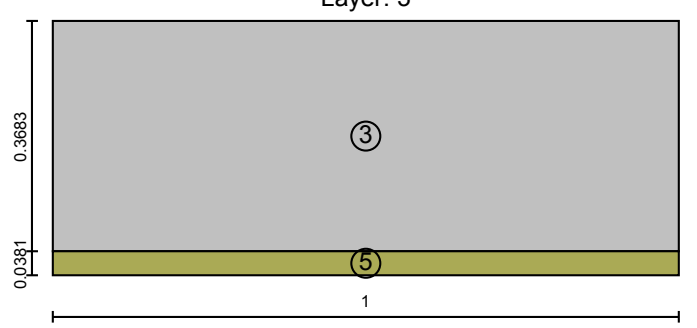


Assembly (Id.29): Roof 0

Inhomogenous layers

Thermal resistance: 0.446 / $0.427 \mathrm{~m}^{2} \mathrm{~K} / \mathrm{W}$ (EN ISO 6946 / homogenous layers)

Heat transfer coefficient( U-Value): $1.55 \mathrm{~W} / \mathrm{m}^{2} \mathrm{~K}$

Thickness: $0.117 \mathrm{~m}$

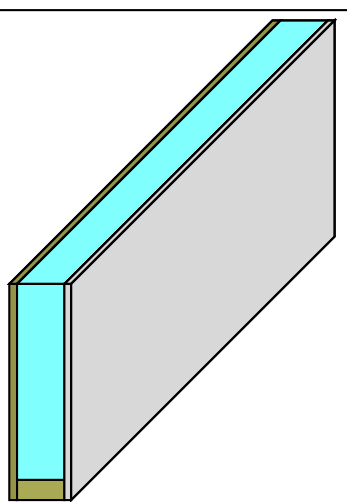

\begin{tabular}{|c|c|c|c|c|c|c|}
\hline $\mathrm{Nr}$. & $\begin{array}{c}\text { Material/Layer } \\
\text { (from outside to inside) }\end{array}$ & $\underset{\left[\mathrm{kg} / \mathrm{m}^{3}\right]}{\rho}$ & $\begin{array}{c}\mathrm{C} \\
{[\mathrm{J} / \mathrm{kgK}]}\end{array}$ & $\begin{array}{c}\lambda \\
{[\mathrm{W} / \mathrm{mK}]}\end{array}$ & $\begin{array}{c}\text { Thickness } \\
{[\mathrm{m}]}\end{array}$ & Color \\
\hline 1 & Plywood (USA) & 470 & 1880 & 0.084 & 0.015 & \\
\hline 2 & Air Layer 90 mm & 1.3 & 1000 & 0.523 & 0.089 & \\
\hline 3 & Interior Gypsum Board & 625 & 870 & 0.16 & 0.013 & \\
\hline \multicolumn{7}{|c|}{ Exchange materials } \\
\hline 4 & Southern Yellow Pine & 500 & 1880 & 0.119 & --- & \\
\hline
\end{tabular}

Exchange material(s), Assembly (Id.29): Roof 0

Layer: 2

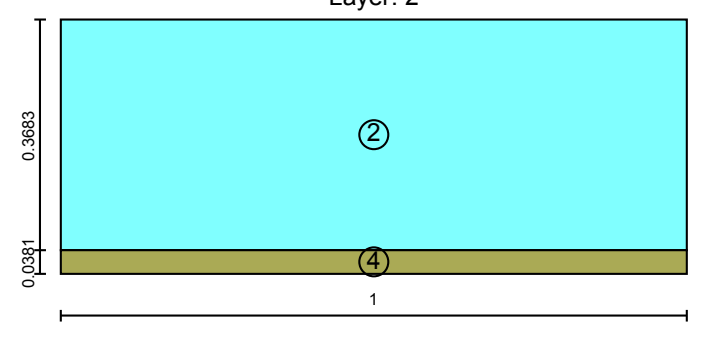


Assembly (Id.28): Roof 1

Inhomogenous layers

Thermal resistance: 2.32 / $2.729 \mathrm{~m}^{2} \mathrm{~K} / \mathrm{W}$ (EN ISO 6946 / homogenous layers)

Heat transfer coefficient( U-Value): $0.4 \mathrm{~W} / \mathrm{m}^{2} \mathrm{~K}$

Thickness: $0.117 \mathrm{~m}$

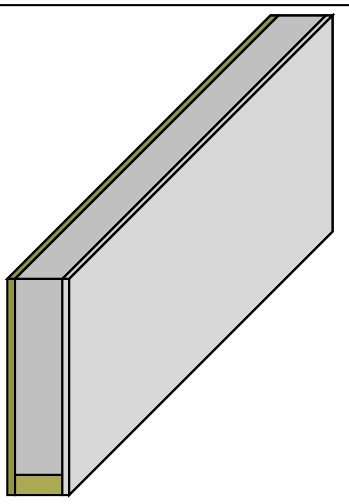

\begin{tabular}{|c|c|c|c|c|c|c|}
\hline Nr. & $\begin{array}{c}\text { Material/Layer } \\
\text { (from outside to inside) }\end{array}$ & $\begin{array}{c}\rho \\
{\left[\mathrm{kg} / \mathrm{m}^{3}\right]}\end{array}$ & $\begin{array}{c}\mathrm{C} \\
{[\mathrm{J} / \mathrm{kgK}]}\end{array}$ & $\begin{array}{c}\lambda \\
{[\mathrm{W} / \mathrm{mK}]}\end{array}$ & $\begin{array}{c}\text { Thickness } \\
{[\mathrm{m}]}\end{array}$ & Color \\
\hline 1 & Plywood (USA) & 470 & 1880 & 0.084 & 0.015 & \\
\hline 2 & Cellulose Fibre Insulation & 30 & 1880 & 0.036 & 0.089 & \\
\hline 3 & Interior Gypsum Board & 625 & 870 & 0.16 & 0.013 & \\
\hline \multicolumn{7}{|c|}{ Exchange materials } \\
\hline 4 & Southern Yellow Pine & 500 & 1880 & 0.119 & -- & \\
\hline
\end{tabular}

Exchange material(s), Assembly (Id.28): Roof 1

Layer: 2

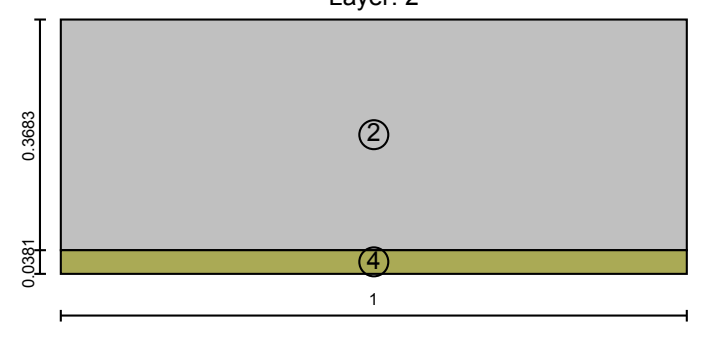


Assembly (Id.27): Roof 2

Inhomogenous layers

Thermal resistance: 3.488 / $4.146 \mathrm{~m}^{2} \mathrm{~K} / \mathrm{W}$ (EN ISO 6946 / homogenous layers)

Heat transfer coefficient( U-Value): $0.27 \mathrm{~W} / \mathrm{m}^{2} \mathrm{~K}$

Thickness: $0.168 \mathrm{~m}$

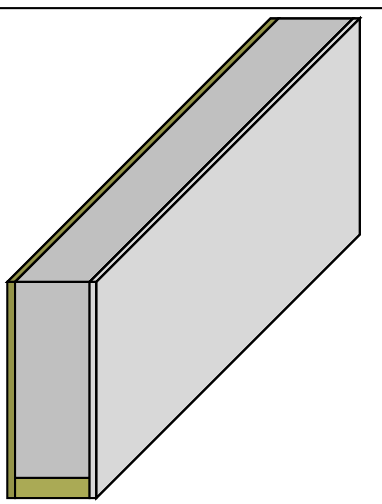

\begin{tabular}{|c|c|c|c|c|c|c|}
\hline $\mathrm{Nr}$. & $\begin{array}{c}\text { Material/Layer } \\
\text { (from outside to inside) }\end{array}$ & $\underset{\left[\mathrm{kg} / \mathrm{m}^{3}\right]}{\rho}$ & $\begin{array}{c}\mathrm{C} \\
{[\mathrm{J} / \mathrm{kgK}]}\end{array}$ & $\begin{array}{c}\lambda \\
{[\mathrm{W} / \mathrm{mK}]}\end{array}$ & $\begin{array}{c}\text { Thickness } \\
{[\mathrm{m}]}\end{array}$ & Color \\
\hline 1 & Plywood (USA) & 470 & 1880 & 0.084 & 0.015 & \\
\hline 2 & Cellulose Fibre Insulation & 30 & 1880 & 0.036 & 0.14 & \\
\hline 3 & Interior Gypsum Board & 625 & 870 & 0.16 & 0.013 & \\
\hline \multicolumn{7}{|c|}{ Exchange materials } \\
\hline 4 & Southern Yellow Pine & 500 & 1880 & 0.119 & --- & \\
\hline
\end{tabular}

Exchange material(s), Assembly (Id.27): Roof 2

Layer: 2

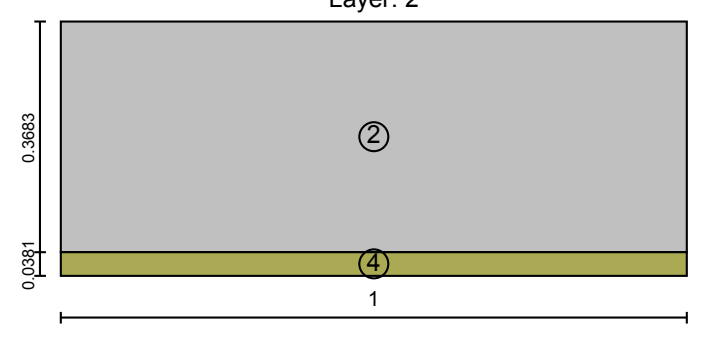


Assembly (Id.26): Roof 3

Inhomogenous layers

Thermal resistance: 6.381 / $6.923 \mathrm{~m}^{2} \mathrm{~K} / \mathrm{W}$ (EN ISO 6946 / homogenous layers)

Heat transfer coefficient( U-Value): $0.15 \mathrm{~W} / \mathrm{m}^{2} \mathrm{~K}$

Thickness: $0.268 \mathrm{~m}$

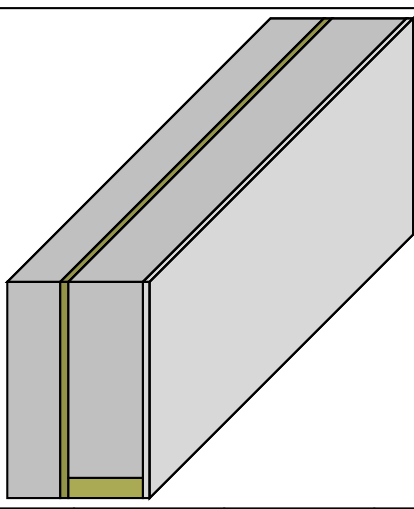

\begin{tabular}{|c|c|c|c|c|c|c|}
\hline Nr. & $\begin{array}{c}\text { Material/Layer } \\
\text { (from outside to inside) }\end{array}$ & $\begin{array}{c}\rho \\
{\left[\mathrm{kg} / \mathrm{m}^{3}\right]}\end{array}$ & $\frac{\mathrm{C}}{[\mathrm{J} / \mathrm{kgK}]}$ & $\begin{array}{c}\lambda \\
{[\mathrm{W} / \mathrm{mK}]}\end{array}$ & $\begin{array}{l}\text { Thickness } \\
{[\mathrm{m}]}\end{array}$ & Color \\
\hline 1 & Cellulose Fibre Insulation & 30 & 1880 & 0.036 & 0.1 & \\
\hline 2 & Plywood (USA) & 470 & 1880 & 0.084 & 0.015 & \\
\hline 3 & Cellulose Fibre Insulation & 30 & 1880 & 0.036 & 0.14 & \\
\hline 4 & Interior Gypsum Board & 625 & 870 & 0.16 & 0.013 & \\
\hline \multicolumn{7}{|c|}{ Exchange materials } \\
\hline 5 & Southern Yellow Pine & 500 & 1880 & 0.119 & --- & \\
\hline
\end{tabular}

Exchange material(s), Assembly (Id.26): Roof 3

Layer: 3

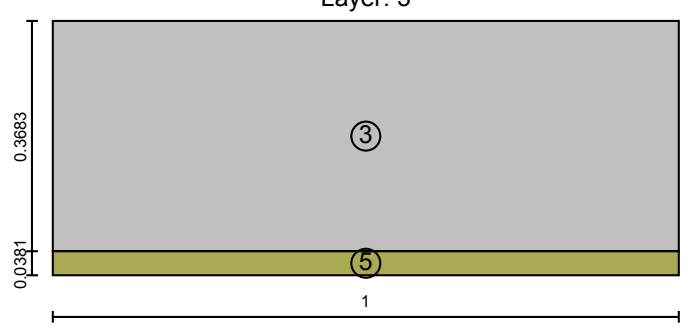


Assembly (Id.30): Roof 4

Inhomogenous layers

Thermal resistance: 9.185 / $9.701 \mathrm{~m}^{2} \mathrm{~K} / \mathrm{W}$ (EN ISO 6946 / homogenous layers)

Heat transfer coefficient( U-Value): $0.11 \mathrm{~W} / \mathrm{m}^{2} \mathrm{~K}$

Thickness: $0.368 \mathrm{~m}$

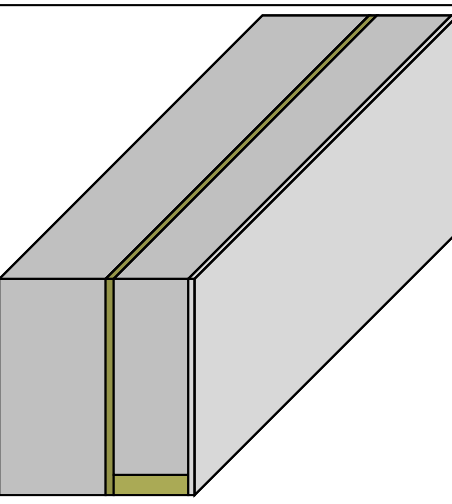

\begin{tabular}{|c|c|c|c|c|c|c|}
\hline $\mathrm{Nr}$. & $\begin{array}{c}\text { Material/Layer } \\
\text { (from outside to inside) }\end{array}$ & $\begin{array}{c}\rho \\
{\left[\mathrm{kg} / \mathrm{m}^{3}\right]}\end{array}$ & $\begin{array}{c}\mathrm{C} \\
{[\mathrm{J} / \mathrm{kgK}]}\end{array}$ & $\begin{array}{c}\lambda \\
{[\mathrm{W} / \mathrm{mK}]}\end{array}$ & $\begin{array}{c}\text { Thickness } \\
{[\mathrm{m}]}\end{array}$ & Color \\
\hline 1 & Cellulose Fibre Insulation & 30 & 1880 & 0.036 & 0.2 & \\
\hline 2 & Plywood (USA) & 470 & 1880 & 0.084 & 0.015 & \\
\hline 3 & Cellulose Fibre Insulation & 30 & 1880 & 0.036 & 0.14 & \\
\hline 4 & Interior Gypsum Board & 625 & 870 & 0.16 & 0.013 & \\
\hline \multicolumn{7}{|c|}{ Exchange materials } \\
\hline 5 & Southern Yellow Pine & 500 & 1880 & 0.119 & --- & \\
\hline
\end{tabular}

Exchange material(s), Assembly (Id.30): Roof 4

Layer: 3

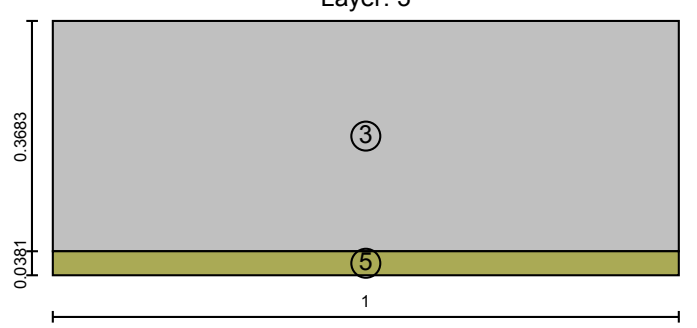


Assembly (Id.31): Roof 5

Inhomogenous layers

Thermal resistance: 11.975 / 12.479 m²K/W (EN ISO 6946 / homogenous layers)

Heat transfer coefficient( U-Value): $0.08 \mathrm{~W} / \mathrm{m}^{2} \mathrm{~K}$

Thickness: $0.468 \mathrm{~m}$

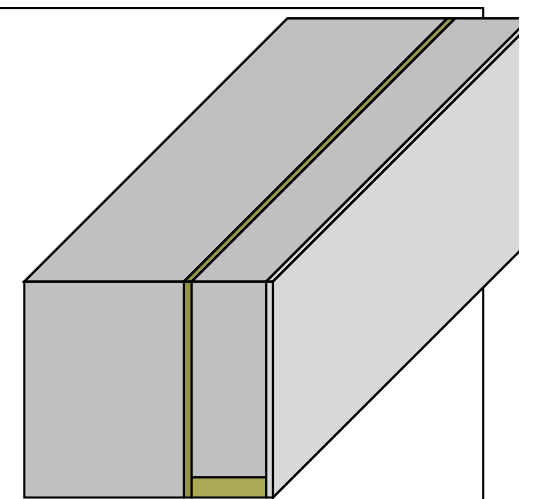

\begin{tabular}{|c|c|c|c|c|c|c|}
\hline $\mathrm{Nr}$. & $\begin{array}{c}\text { Material/Layer } \\
\text { (from outside to inside) }\end{array}$ & $\stackrel{\rho}{\left[\mathrm{kg} / \mathrm{m}^{3}\right]}$ & $\begin{array}{c}\mathrm{C} \\
{[\mathrm{J} / \mathrm{kgK}]}\end{array}$ & $\begin{array}{c}\lambda \\
{[\mathrm{W} / \mathrm{mK}]}\end{array}$ & $\begin{array}{l}\text { Thickness } \\
{[\mathrm{m}]}\end{array}$ & Color \\
\hline 1 & Cellulose Fibre Insulation & 30 & 1880 & 0.036 & 0.3 & \\
\hline 2 & Plywood (USA) & 470 & 1880 & 0.084 & 0.015 & \\
\hline 3 & Cellulose Fibre Insulation & 30 & 1880 & 0.036 & 0.14 & \\
\hline \multicolumn{7}{|c|}{ Exchange materials } \\
\hline 5 & Southern Yellow Pine & 500 & 1880 & 0.119 & --- & \\
\hline
\end{tabular}

Exchange material(s), Assembly (Id.31): Roof 5

Layer: 3

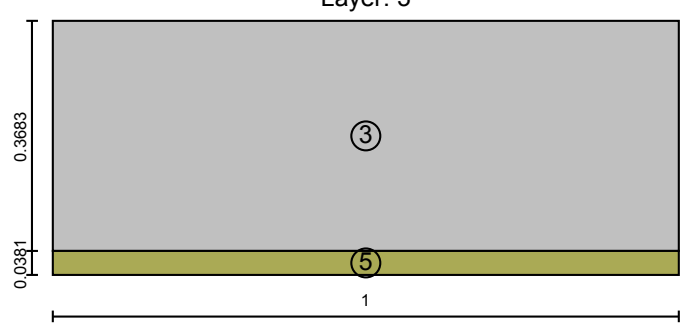


Assembly (Id.32): Roof 6

Inhomogenous layers

Thermal resistance: $14.76 / 15.257 \mathrm{~m}^{2} \mathrm{~K} / \mathrm{W}$ (EN ISO 6946 / homogenous layers)

Heat transfer coefficient( U-Value): $0.07 \mathrm{~W} / \mathrm{m}^{2} \mathrm{~K}$

Thickness: $0.568 \mathrm{~m}$

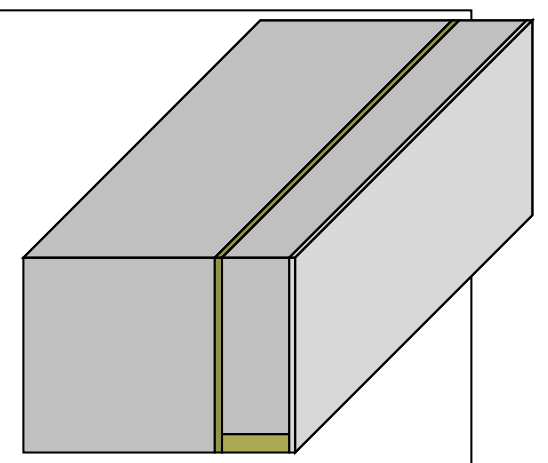

\begin{tabular}{|c|c|c|c|c|c|c|}
\hline $\mathrm{Nr}$. & $\begin{array}{c}\text { Material/Layer } \\
\text { (from outside to inside) }\end{array}$ & $\begin{array}{c}\rho \\
{\left[\mathrm{kg} / \mathrm{m}^{3}\right]}\end{array}$ & $\begin{array}{c}\mathrm{C} \\
{[\mathrm{J} / \mathrm{kgK}]}\end{array}$ & $\begin{array}{c}\lambda \\
{[\mathrm{W} / \mathrm{mK}]}\end{array}$ & $\begin{array}{l}\text { Thickness } \\
{[\mathrm{m}]}\end{array}$ & Color \\
\hline 1 & Cellulose Fibre Insulation & 30 & 1880 & 0.036 & 0.4 & \\
\hline 2 & Plywood (USA) & 470 & 1880 & 0.084 & 0.015 & \\
\hline 3 & Cellulose Fibre Insulation & 30 & 1880 & 0.036 & 0.14 & \\
\hline 4 & Interior Gypsum Board & 625 & 870 & 0.16 & 0.013 & \\
\hline \multicolumn{7}{|c|}{ Exchange materials } \\
\hline 5 & Southern Yellow Pine & 500 & 1880 & 0.119 & --- & \\
\hline
\end{tabular}

Exchange material(s), Assembly (Id.32): Roof 6

Layer: 3

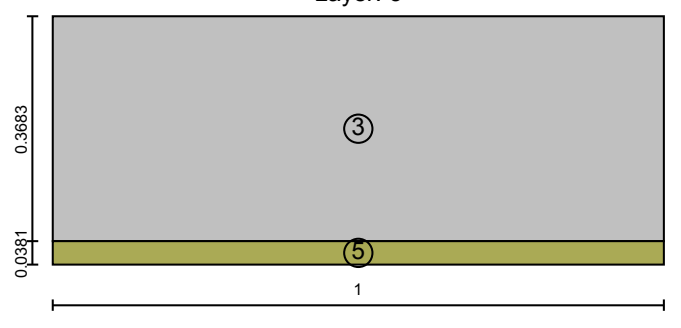


Assembly (Id.33): Roof 7

Inhomogenous layers

Thermal resistance: 17.542 / 18.034 m²K/W (EN ISO 6946 / homogenous layers)

Heat transfer coefficient( U-Value): $0.06 \mathrm{~W} / \mathrm{m}^{2} \mathrm{~K}$

Thickness: $0.668 \mathrm{~m}$

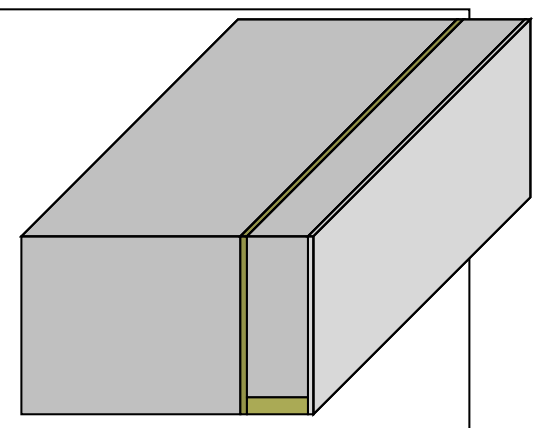

\begin{tabular}{|c|c|c|c|c|c|c|}
\hline $\mathrm{Nr}$. & $\begin{array}{c}\text { Material/Layer } \\
\text { (from outside to inside) }\end{array}$ & $\begin{array}{c}\rho \\
{\left[\mathrm{kg} / \mathrm{m}^{3}\right]}\end{array}$ & $\begin{array}{c}\mathrm{C} \\
{[\mathrm{J} / \mathrm{kgK}]}\end{array}$ & $\begin{array}{c}\lambda \\
{[\mathrm{W} / \mathrm{mK}]}\end{array}$ & $\begin{array}{l}\text { Thickness } \\
{[\mathrm{m}]}\end{array}$ & Color \\
\hline 1 & Cellulose Fibre Insulation & 30 & 1880 & 0.036 & 0.5 & \\
\hline 2 & Plywood (USA) & 470 & 1880 & 0.084 & 0.015 & \\
\hline 3 & Cellulose Fibre Insulation & 30 & 1880 & 0.036 & 0.14 & \\
\hline 4 & Interior Gypsum Board & 625 & 870 & 0.16 & 0.013 & \\
\hline \multicolumn{7}{|c|}{ Exchange materials } \\
\hline 5 & Southern Yellow Pine & 500 & 1880 & 0.119 & --- & \\
\hline
\end{tabular}

Exchange material(s), Assembly (Id.33): Roof 7

Layer: 3

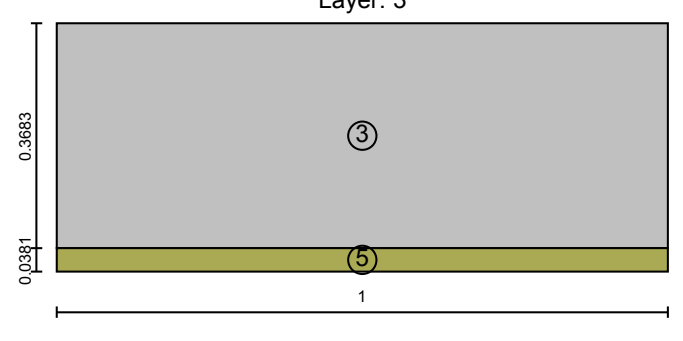


Assembly (Id.34): Roof 8

Inhomogenous layers

Thermal resistance: 20.322 / 20.812 m²K/W (EN ISO 6946 / homogenous layers)

Heat transfer coefficient( U-Value): $0.05 \mathrm{~W} / \mathrm{m}^{2} \mathrm{~K}$

Thickness: $0.768 \mathrm{~m}$

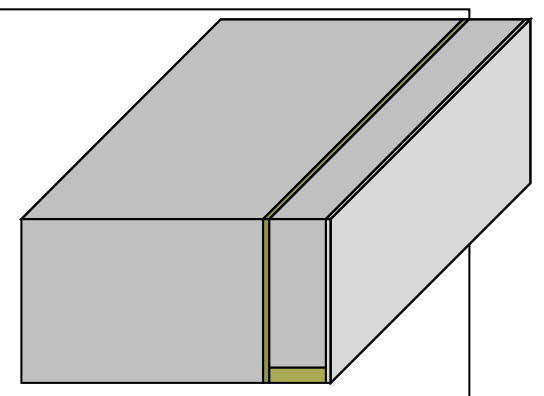

\begin{tabular}{|c|c|c|c|c|c|c|}
\hline $\mathrm{Nr}$. & $\begin{array}{c}\text { Material/Layer } \\
\text { (from outside to inside) }\end{array}$ & $\begin{array}{c}\rho \\
{\left[\mathrm{kg} / \mathrm{m}^{3}\right]}\end{array}$ & $\begin{array}{c}\mathrm{C} \\
{[\mathrm{J} / \mathrm{kgK}]}\end{array}$ & $\begin{array}{c}\lambda \\
{[\mathrm{W} / \mathrm{mK}]}\end{array}$ & $\begin{array}{l}\text { Thickness } \\
{[\mathrm{m}]}\end{array}$ & Color \\
\hline 1 & Cellulose Fibre Insulation & 30 & 1880 & 0.036 & 0.6 & \\
\hline 2 & Plywood (USA) & 470 & 1880 & 0.084 & 0.015 & \\
\hline 3 & Cellulose Fibre Insulation & 30 & 1880 & 0.036 & 0.14 & \\
\hline 4 & Interior Gypsum Board & 625 & 870 & 0.16 & 0.013 & \\
\hline \multicolumn{7}{|c|}{ Exchange materials } \\
\hline 5 & Southern Yellow Pine & 500 & 1880 & 0.119 & --- & \\
\hline
\end{tabular}

Exchange material(s), Assembly (Id.34): Roof 8

Layer: 3

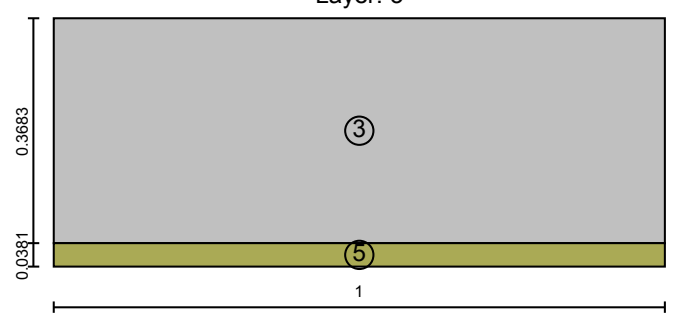


Assembly (Id.35): Roof 9

Inhomogenous layers

Thermal resistance: 23.103 / $23.59 \mathrm{~m}^{2} \mathrm{~K} / \mathrm{W}$ (EN ISO 6946 / homogenous layers)

Heat transfer coefficient( U-Value): $0.04 \mathrm{~W} / \mathrm{m}^{2} \mathrm{~K}$

Thickness: $0.868 \mathrm{~m}$

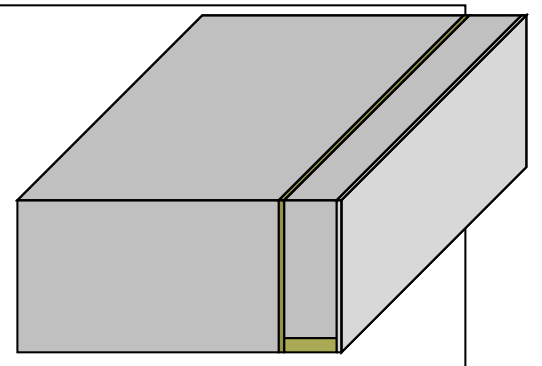

\begin{tabular}{|l|l|c|c|c|c|c|}
\hline \multicolumn{1}{|c|}{$\begin{array}{c}\text { Material/Layer } \\
\text { Nr. }\end{array}$} & \multicolumn{1}{|c|}{$\begin{array}{c}\rho \\
{\left[\mathrm{kg} / \mathrm{m}^{3}\right]}\end{array}$} & $\begin{array}{c}\mathrm{c} \\
{[\mathrm{J} / \mathrm{kgK}]}\end{array}$ & $\begin{array}{c}\lambda \\
{[\mathrm{W} / \mathrm{mK}]}\end{array}$ & $\begin{array}{c}\text { Thickness } \\
{[\mathrm{m}]}\end{array}$ & Color \\
\hline 1 & Cellulose Fibre Insulation to inside) & 30 & 1880 & 0.036 & 0.7 & \\
\hline 2 & Plywood (USA) & 470 & 1880 & 0.084 & 0.015 & \\
\hline 3 & Cellulose Fibre Insulation & 30 & 1880 & 0.036 & 0.14 & \\
\hline 4 & Interior Gypsum Board & 625 & 870 & 0.16 & 0.013 & \\
\hline \multicolumn{7}{|l|}{ Exchange materials } \\
\hline 5
\end{tabular}

Exchange material(s), Assembly (Id.35): Roof 9

$$
\text { Layer: } 3
$$

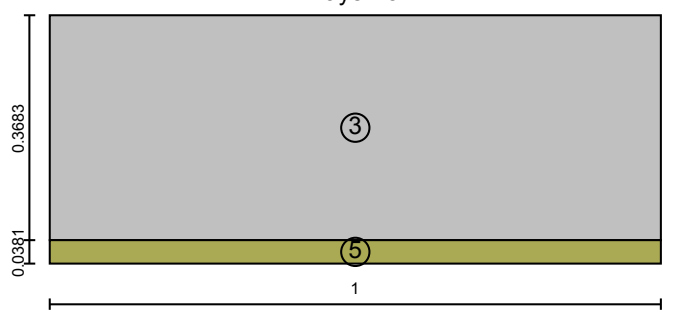


Assembly (Id.36): Roof 10

Inhomogenous layers

Thermal resistance: 25.882 / $26.368 \mathrm{~m}^{2} \mathrm{~K} / \mathrm{W}$ (EN ISO 6946 / homogenous layers)

Heat transfer coefficient( U-Value): $0.04 \mathrm{~W} / \mathrm{m}^{2} \mathrm{~K}$

Thickness: $0.968 \mathrm{~m}$

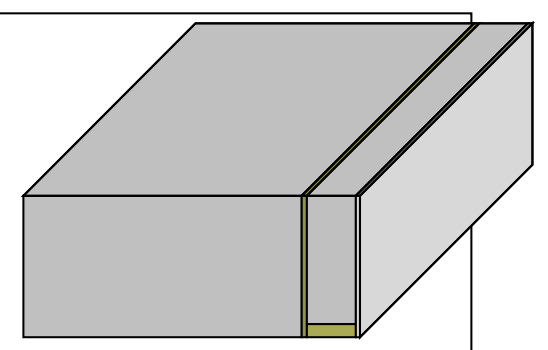

\begin{tabular}{|c|c|c|c|c|c|c|}
\hline $\mathrm{Nr}$. & $\begin{array}{c}\text { Material/Layer } \\
\text { (from outside to inside) }\end{array}$ & $\begin{array}{c}\rho \\
{\left[\mathrm{kg} / \mathrm{m}^{3}\right]}\end{array}$ & $\begin{array}{c}\mathrm{C} \\
{[\mathrm{J} / \mathrm{kgK}]}\end{array}$ & $\begin{array}{c}\lambda \\
{[\mathrm{W} / \mathrm{mK}]}\end{array}$ & $\begin{array}{l}\text { Thickness } \\
{[\mathrm{m}]}\end{array}$ & Color \\
\hline 1 & Cellulose Fibre Insulation & 30 & 1880 & 0.036 & 0.8 & \\
\hline 2 & Plywood (USA) & 470 & 1880 & 0.084 & 0.015 & \\
\hline 3 & Cellulose Fibre Insulation & 30 & 1880 & 0.036 & 0.14 & \\
\hline 4 & Interior Gypsum Board & 625 & 870 & 0.16 & 0.013 & \\
\hline \multicolumn{7}{|c|}{ Exchange materials } \\
\hline 5 & Southern Yellow Pine & 500 & 1880 & 0.119 & --- & \\
\hline
\end{tabular}

Exchange material(s), Assembly (Id.36): Roof 10

Layer: 3

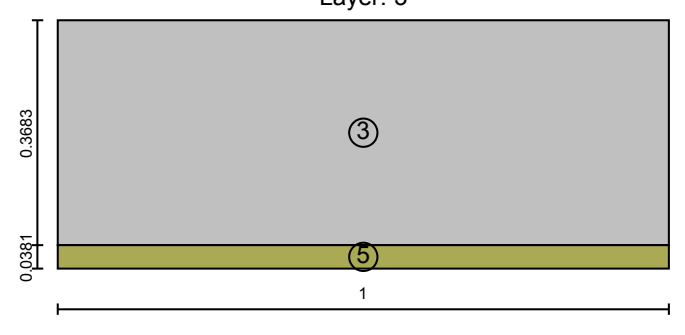


Assembly (Id.16): Reference Building Slab

\begin{tabular}{|c|c|c|c|c|c|c|}
\hline \multicolumn{7}{|c|}{$\begin{array}{l}\text { Homogenous layers } \\
\text { Thermal resistance: } 7.203 \mathrm{~m}^{2} \mathrm{~K} / \mathrm{W}\end{array}$} \\
\hline \multicolumn{7}{|c|}{ Thickness: $0.457 \mathrm{~m}$} \\
\hline $\mathrm{Nr}$. & $\begin{array}{c}\text { Material/Layer } \\
\text { (from outside to inside) }\end{array}$ & $\begin{array}{c}\rho \\
{\left[\mathrm{kg} / \mathrm{m}^{3}\right]}\end{array}$ & $\begin{array}{c}\mathrm{C} \\
{[\mathrm{J} / \mathrm{kgK}]}\end{array}$ & $\begin{array}{c}\lambda \\
{[\mathrm{W} / \mathrm{mK}]}\end{array}$ & $\begin{array}{l}\text { Thickness } \\
{[\mathrm{m}]}\end{array}$ & Color \\
\hline 1 & Expanded Polystyrene Insulation & 14.8 & 1470 & 0.036 & 0.254 & \\
\hline 2 & Concrete & 2104 & 776 & 1.373 & 0.203 & \\
\hline
\end{tabular}


Assembly (Id.38): Slab 0

\begin{tabular}{|c|c|c|c|c|c|c|}
\hline \multicolumn{7}{|c|}{$\begin{array}{l}\text { Homogenous layers } \\
\text { Thermal resistance: } 0.148 \mathrm{~m}^{2} \mathrm{~K} / \mathrm{W}\end{array}$} \\
\hline \multicolumn{7}{|c|}{ Heat transfer coefficient( U-Value): $3.15 \mathrm{~W} / \mathrm{m}^{2} \mathrm{~K}$} \\
\hline $\mathrm{Nr}$. & $\begin{array}{c}\text { Material/Layer } \\
\text { (from outside to inside) }\end{array}$ & $\begin{array}{c}\rho \\
{\left[\mathrm{kg} / \mathrm{m}^{3}\right]}\end{array}$ & $\begin{array}{c}\mathrm{c} \\
{[\mathrm{J} / \mathrm{kgK}]}\end{array}$ & $\begin{array}{c}\lambda \\
{[\mathrm{W} / \mathrm{mK}]}\end{array}$ & $\begin{array}{l}\text { Thickness } \\
{[\mathrm{m}]}\end{array}$ & Color \\
\hline 1 & Concrete & 2104 & 776 & 1.373 & 0.203 & \\
\hline
\end{tabular}


Assembly (Id.37): Slab 1

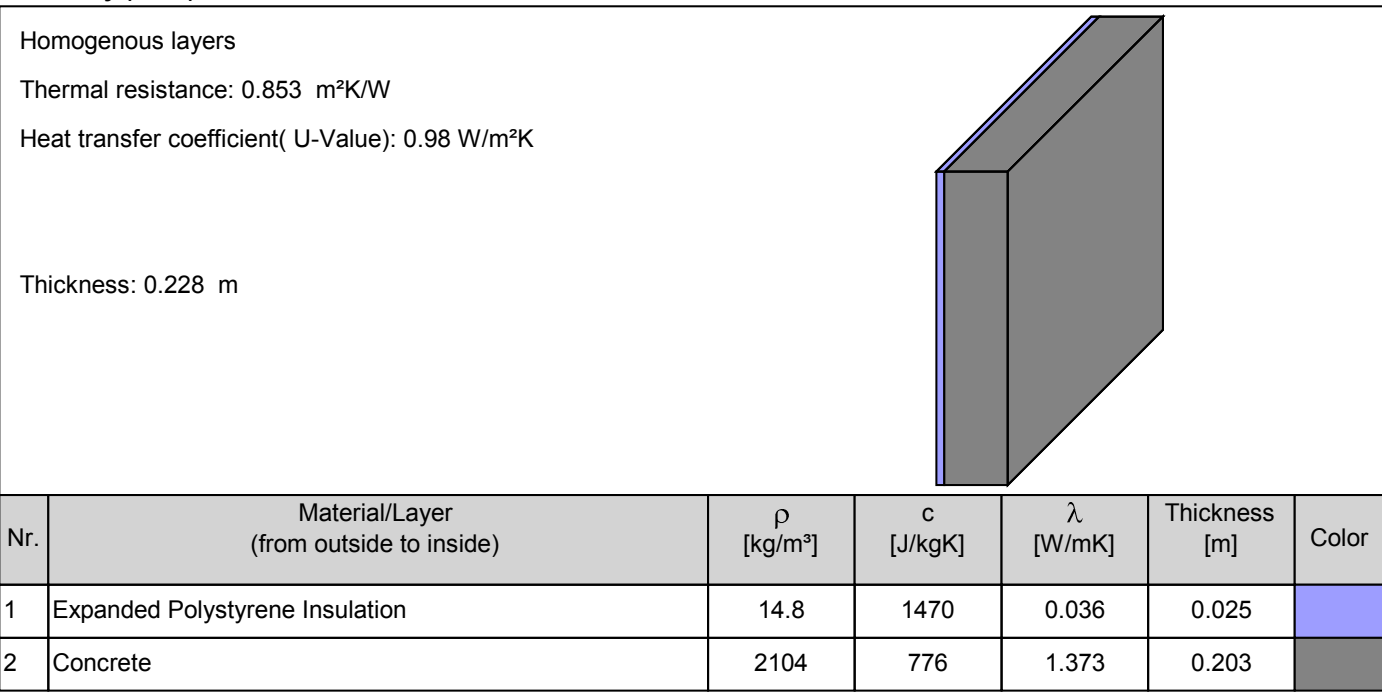


Assembly (Id.39): Slab 2

\begin{tabular}{|c|c|c|c|c|c|c|}
\hline & $\begin{array}{l}\text { mogenous layers } \\
\text { ermal resistance: } 1.559 \mathrm{~m}^{2} \mathrm{~K} / \mathrm{W} \\
\text { at transfer coefficient( U-Value): } 0.58 \mathrm{~W} / \mathrm{m}\end{array}$ & \multicolumn{5}{|c|}{ Thermal resistance: $1.559 \mathrm{~m}^{2} \mathrm{~K} / \mathrm{W}$} \\
\hline \multicolumn{7}{|c|}{ Thickness: $0.254 \mathrm{~m}$} \\
\hline $\mathrm{Nr}$ & $\begin{array}{c}\text { Material/Layer } \\
\text { (from outside to inside) }\end{array}$ & $\begin{array}{c}\rho \\
{\left[\mathrm{kg} / \mathrm{m}^{3}\right]}\end{array}$ & $\begin{array}{c}\mathrm{c} \\
{[\mathrm{J} / \mathrm{kgK}]}\end{array}$ & $\frac{\lambda}{[\mathrm{W} / \mathrm{mK}]}$ & $\begin{array}{l}\text { Thickness } \\
{[\mathrm{m}]}\end{array}$ & Color \\
\hline 1 & Expanded Polystyrene Insulation & 14.8 & 1470 & 0.036 & 0.051 & \\
\hline 2 & Concrete & 2104 & 776 & 1.373 & 0.203 & \\
\hline
\end{tabular}


Assembly (Id.40): Slab 3

\begin{tabular}{|c|c|c|c|c|c|c|}
\hline \multicolumn{7}{|c|}{$\begin{array}{l}\text { Homogenous layers } \\
\text { Thermal resistance: } 2.265 \mathrm{~m}^{2} \mathrm{~K} / \mathrm{W} \\
\text { Heat transfer coefficient( U-Value): } 0.41 \mathrm{~W} / \mathrm{m}^{2} \mathrm{~K}\end{array}$} \\
\hline \multicolumn{7}{|c|}{ Thickness: $0.279 \mathrm{~m}$} \\
\hline $\mathrm{Nr}$ & $\begin{array}{c}\text { Material/Layer } \\
\text { (from outside to inside) }\end{array}$ & $\begin{array}{c}\rho \\
{\left[\mathrm{kg} / \mathrm{m}^{3}\right]}\end{array}$ & $\begin{array}{c}\mathrm{c} \\
{[\mathrm{J} / \mathrm{kgK}]}\end{array}$ & $\frac{\lambda}{[\mathrm{W} / \mathrm{mK}]}$ & $\begin{array}{l}\text { Thickness } \\
{[\mathrm{m}]}\end{array}$ & Color \\
\hline 1 & Expanded Polystyrene Insulation & 14.8 & 1470 & 0.036 & 0.076 & \\
\hline 2 & Concrete & 2104 & 776 & 1.373 & 0.203 & \\
\hline
\end{tabular}


Assembly (Id.41): Slab 4

Homogenous layers
Thermal resistance: $2.97 \mathrm{~m}^{2} \mathrm{~K} / \mathrm{W}$
Heat transfer coefficient( U-Value): $0.32 \mathrm{~W} / \mathrm{m}^{2} \mathrm{~K}$
Thickness: $0.305 \mathrm{~m}$
(from outside to inside)
Nr.


Assembly (Id.42): Slab 5

\begin{tabular}{|c|c|c|c|c|c|c|}
\hline \multicolumn{7}{|c|}{$\begin{array}{l}\text { Homogenous layers } \\
\text { Thermal resistance: } 4.381 \mathrm{~m}^{2} \mathrm{~K} / \mathrm{W} \\
\text { Heat transfer coefficient( U-Value): } 0.22 \mathrm{~W} / \mathrm{m}^{2} \mathrm{~K}\end{array}$} \\
\hline \multicolumn{7}{|c|}{ Thickness: $0.355 \mathrm{~m}$} \\
\hline $\mathrm{Nr}$ & $\begin{array}{c}\text { Material/Layer } \\
\text { (from outside to inside) }\end{array}$ & $\begin{array}{c}\rho \\
{\left[\mathrm{kg} / \mathrm{m}^{3}\right]}\end{array}$ & $\begin{array}{c}\mathrm{c} \\
{[\mathrm{J} / \mathrm{kgK}]}\end{array}$ & $\begin{array}{c}\lambda \\
{[\mathrm{W} / \mathrm{mK}]}\end{array}$ & $\begin{array}{l}\text { Thickness } \\
{[\mathrm{m}]}\end{array}$ & Color \\
\hline 1 & Expanded Polystyrene Insulation & 14.8 & 1470 & 0.036 & 0.152 & \\
\hline 2 & Concrete & 2104 & 776 & 1.373 & 0.203 & \\
\hline
\end{tabular}


Assembly (Id.43): Slab 6

Homogenous layers

Thermal resistance: $5.792 \mathrm{~m}^{2} \mathrm{~K} / \mathrm{W}$

Heat transfer coefficient( U-Value): $0.17 \mathrm{~W} / \mathrm{m}^{2} \mathrm{~K}$

Thickness: $0.406 \mathrm{~m}$

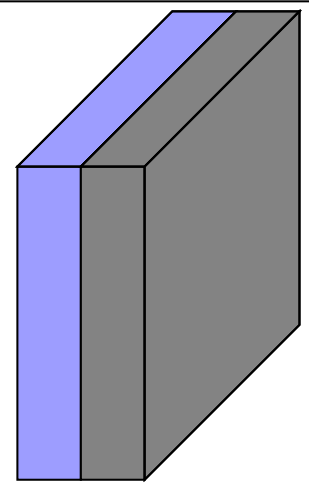

\begin{tabular}{|c|c|c|c|c|c|c|}
\hline $\mathrm{Nr}$. & $\begin{array}{c}\text { Material/Layer } \\
\text { (from outside to inside) }\end{array}$ & $\stackrel{\rho}{\left[\mathrm{kg} / \mathrm{m}^{3}\right]}$ & $\begin{array}{c}\mathrm{C} \\
{[\mathrm{J} / \mathrm{kgK}]}\end{array}$ & $\begin{array}{c}\lambda \\
{[\mathrm{W} / \mathrm{mK}]}\end{array}$ & $\begin{array}{l}\text { Thickness } \\
{[\mathrm{m}]}\end{array}$ & Color \\
\hline 1 & Expanded Polystyrene Insulation & 14.8 & 1470 & 0.036 & 0.203 & \\
\hline 2 & Concrete & 2104 & 776 & 1.373 & 0.203 & \\
\hline
\end{tabular}


Assembly (Id.44): Slab 7

Homogenous layers

Thermal resistance: $7.203 \mathrm{~m}^{2} \mathrm{~K} / \mathrm{W}$

Heat transfer coefficient( U-Value): $0.14 \mathrm{~W} / \mathrm{m}^{2} \mathrm{~K}$

Thickness: $0.457 \mathrm{~m}$

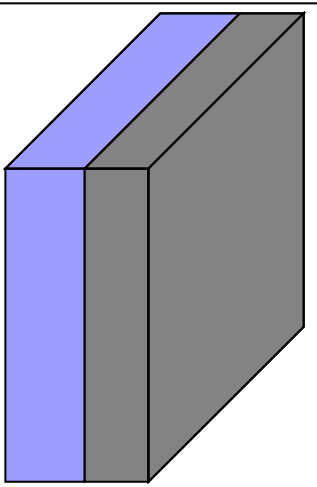

\begin{tabular}{|c|c|c|c|c|c|c|}
\hline $\mathrm{Nr}$. & $\begin{array}{c}\text { Material/Layer } \\
\text { (from outside to inside) }\end{array}$ & $\begin{array}{c}\rho \\
{\left[\mathrm{kg} / \mathrm{m}^{3}\right]}\end{array}$ & $\begin{array}{c}\mathrm{C} \\
{[\mathrm{J} / \mathrm{kgK}]}\end{array}$ & $\begin{array}{c}\lambda \\
{[\mathrm{W} / \mathrm{mK}]}\end{array}$ & $\begin{array}{l}\text { Thickness } \\
{[\mathrm{m}]}\end{array}$ & Color \\
\hline 1 & Expanded Polystyrene Insulation & 14.8 & 1470 & 0.036 & 0.254 & \\
\hline 2 & Concrete & 2104 & 776 & 1.373 & 0.203 & \\
\hline
\end{tabular}


Assembly (Id.45): Slab 8

Homogenous layers

Thermal resistance: $8.615 \mathrm{~m}^{2} \mathrm{~K} / \mathrm{W}$

Heat transfer coefficient( U-Value): $0.11 \mathrm{~W} / \mathrm{m}^{2} \mathrm{~K}$

Thickness: $0.508 \mathrm{~m}$

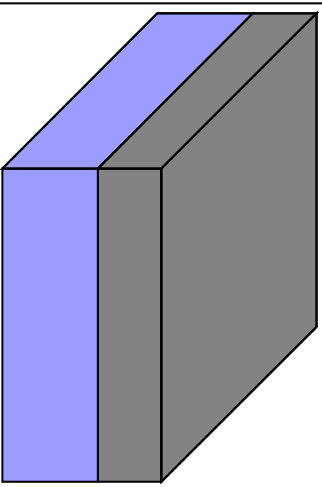

\begin{tabular}{|c|c|c|c|c|c|c|}
\hline $\mathrm{Nr}$. & $\begin{array}{c}\text { Material/Layer } \\
\text { (from outside to inside) }\end{array}$ & $\begin{array}{c}\rho \\
{\left[\mathrm{kg} / \mathrm{m}^{3}\right]}\end{array}$ & $\begin{array}{c}\mathrm{C} \\
{[\mathrm{J} / \mathrm{kgK}]}\end{array}$ & $\begin{array}{c}\lambda \\
{[\mathrm{W} / \mathrm{mK}]}\end{array}$ & $\begin{array}{l}\text { Thickness } \\
{[\mathrm{m}]}\end{array}$ & Color \\
\hline 1 & Expanded Polystyrene Insulation & 14.8 & 1470 & 0.036 & 0.305 & \\
\hline 2 & Concrete & 2104 & 776 & 1.373 & 0.203 & \\
\hline
\end{tabular}


Assembly (Id.46): Slab 9

Homogenous layers

Thermal resistance: $10.026 \mathrm{~m}^{2} \mathrm{~K} / \mathrm{W}$

Heat transfer coefficient( U-Value): $0.1 \mathrm{~W} / \mathrm{m}^{2} \mathrm{~K}$

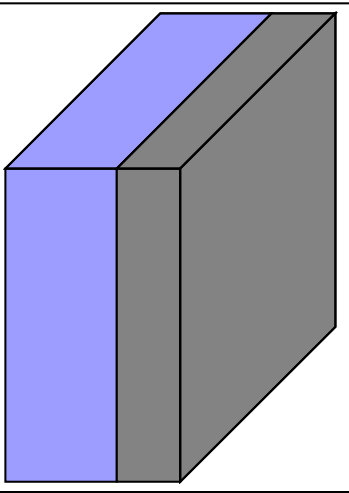

\begin{tabular}{|c|c|c|c|c|c|c|}
\hline $\mathrm{Nr}$. & $\begin{array}{c}\text { Material/Layer } \\
\text { (from outside to inside) }\end{array}$ & $\begin{array}{c}\rho \\
{\left[\mathrm{kg} / \mathrm{m}^{3}\right]}\end{array}$ & $\begin{array}{c}\mathrm{C} \\
{[\mathrm{J} / \mathrm{kgK}]}\end{array}$ & $\begin{array}{c}\lambda \\
{[\mathrm{W} / \mathrm{mK}]}\end{array}$ & $\begin{array}{l}\text { Thickness } \\
{[\mathrm{m}]}\end{array}$ & Color \\
\hline 1 & Expanded Polystyrene Insulation & 14.8 & 1470 & 0.036 & 0.356 & \\
\hline 2 & Concrete & 2104 & 776 & 1.373 & 0.203 & \\
\hline
\end{tabular}


Assembly (Id.47): Slab 10

Homogenous layers

Thermal resistance: $11.437 \mathrm{~m}^{2} \mathrm{~K} / \mathrm{W}$

Heat transfer coefficient( U-Value): $0.09 \mathrm{~W} / \mathrm{m}^{2} \mathrm{~K}$

Thickness: $0.609 \mathrm{~m}$

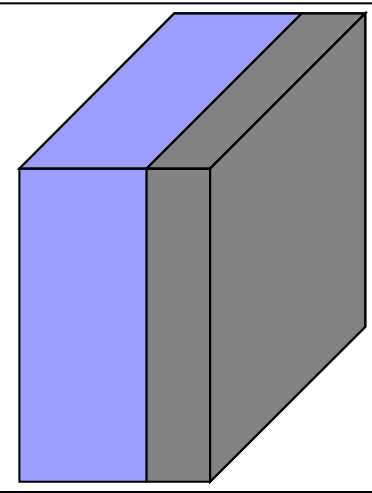

\begin{tabular}{|c|c|c|c|c|c|c|}
\hline $\mathrm{Nr}$. & $\begin{array}{c}\text { Material/Layer } \\
\text { (from outside to inside) }\end{array}$ & $\begin{array}{c}\rho \\
{\left[\mathrm{kg} / \mathrm{m}^{3}\right]}\end{array}$ & $\begin{array}{c}\mathrm{C} \\
{[\mathrm{J} / \mathrm{kgK}]}\end{array}$ & $\begin{array}{c}\lambda \\
{[\mathrm{W} / \mathrm{mK}]}\end{array}$ & $\begin{array}{l}\text { Thickness } \\
{[\mathrm{m}]}\end{array}$ & Color \\
\hline 1 & Expanded Polystyrene Insulation & 14.8 & 1470 & 0.036 & 0.406 & \\
\hline 2 & Concrete & 2104 & 776 & 1.373 & 0.203 & \\
\hline
\end{tabular}




\section{References}

ACCA. (2011). Manual J, Residential Load Calculation, Outdoor Design Conditions. $8^{\text {th }}$ Ed. Version 2. Air Conditioning Contractors of America. Arlington, VA. Retrieved from

http://www.energystar.gov/ia/partners/bldrs_lenders_raters/downloads/Out door_Design_Conditions_508.pdf?c2d1-2f00

Al-Homoud, M. S. (2005). Performance characteristics and practical applications of common building thermal insulation materials. Building and Environment. 40, 353-366.

ASHRAE. (2009). ASHRAE Handbook: Fundamentals (SI). Atlanta, GA.: ASHRAE.

Athena. (2014a). Athena Impact Estimator for Buildings. User Manual and Transparency Document v.5. Retrieved from http://calculatelca.com/wpcontent/uploads/2014/10/IE4B_v5_User_Guide_September_2014.pdf

Athena. (2014b). Athena Sustainable Materials Institute, LCI Databases. Retrieved from http://www.athenasmi.org/our-software-data/lca-databases/

Bolker, B. M. (2008). Ecological Models and Data in R. Princeton, NJ: Princeton University Press.

Bordeleau, S. (2011, March 30). Where Canada's Surplus Energy Goes. CBC News. Retrieved from http://www.cbc.ca/news/canada/where-canada-s-surplusenergy-goes-1.1109321

Bowick, M. F. (2011). A life cycle assessment model of Canadian residential dwellings and building stocks. (Master's dissertation). Retrieved from http://digitalcommons.ryerson.ca/dissertations/834/ 
BRE. (2009). Passivhaus Primer: Introduction. Retrieved from Passive Buildings Canada website http://www.passivebuildings.ca/downloads

BRE. (2011). Passivhaus Primer: Designer's Guide. Retrieved from Building Research Establishment website http://www.passivhaus.org.uk/page.jsp?id=108

CMHC. (2000). Research Highlights. Slab-On-Grade Construction. Technical Series 2000-127. Retrieved from http://www.cmhc-schl.gc.ca/publications/en/rhpr/tech/2000-127E.html

Cotterell, J., \& Dadeby, A. (2012). The Passivhaus Handbook: A practical guide to constructing and retrofitting buildings for ultra-low energy performance. Totnes, U.K.: Green Books.

Dahlstrøm, O., Sørnes, K., Eriksen, S. T., \& Hertwich, E. G. (2012). Life cycle assessment of a single-family residence built to either conventional- or passive house standard. Energy \& Buildings, 54, 470.

DOE. (2012). Heating Fuel Comparison Calculator. Version Heat-CALC-Vsn-D_109.xls (software). Available from http://www.eia.doe.gov/neic/experts/heatcalc.xls

Environment Canada. (2008). Canadian Weather Energy and Engineering Data Sets (CWEEDS Files) and Canadian Weather for Energy Calculations (CWEC Files) Updated User's Manual. Revised October 23, 2008. Retrieved from Environment Canada website: http://climate.weather.gc.ca/prods_servs/engineering_e.html

Environment Canada. (2014a). 1981-2010 Climate Normals \& Averages. Retrieved from http://climate.weather.gc.ca/climate_normals/index_e.html

Environment Canada. (2014b). National Inventory Report 1990-2012 - Part 3. Greenhouse Gas Sources and Sinks in Canada. Retrieved from http://publications.gc.ca/collections/collection_2014/ec/En81-4-2012-3eng.pdf 
Environment Canada. (2014c). National Inventory Report 1990-2012 - Part 2. Greenhouse Gas Sources and Sinks in Canada. Retrieved from http://publications.gc.ca/collections/collection_2014/ec/En81-4-2012-2eng.pdf

Fairey, P., Parker, D., Wilcox, B., \& Lombardi, M. (2004). Climate Impacts on Heating Seasonal Performance Factor (HSPF) and Seasonal Energy Efficiency Ratio (SEER) for Air Source Heat Pumps. ASHRAE Transactions, Atlanta, GA.: American Society of Heating, Refrigerating and Air Conditioning Engineers, Inc.

Feist, W. (1997). Lebenszyklus Bilanzen im Vergleich: Niedrigenergiehaus, Passivhaus, Energieautarkes Haus; in: Arbeitskreis kostengünstige Passivhaüser, Protokollband Nr. 8. Darmstadt: Passive House Institute.

Feist, W. (2007). Passive House Planning Package 2007, Passive House Institute, Technical Information PHI-2007/1 (E). Darmstadt: Wolfgang Feist.

Flager, F., Basbagill, J., Lepech, M. \& Fischer, M. (2012). Multiobjective building envelope optimization for life-cycle cost and global warming potential. eWork and eBusiness in Architecture, Engineering and Construction: ECPPM 2012 (193200). Amsterdam: Taylor \& Francis.

Fraunhofer Institute for Building Physics. (2012). Adoption of Passive House building principles is accelerating worldwide. Retrieved from http://www.ibp.fraunhofer.de/en/Press/Press_releases/pm_06-092012_passivehouses.html

Gustavsson, L., \& Joelsson, A. (2010). Life cycle primary energy analysis of residential buildings. Energy \& Buildings, 42(2), 210-220.

Harvey, D. (2007). Net climatic impact of solid foam insulation produced with halocarbon and non-halocarbon blowing agents. Building and Environment. 42(8). 2860-2879. 
Hammer \& Hand. (2014). Custom High Performance Doors. Retrieved from http://hammerandhand.com/documents/H+H_High-Performance-Doors.pdf

Himpe, E., Trappers, L., Debacker, W., Delghust, M., Laverge, J., Janssens, A., Moens, J., \& Van Holm, M. (2013). Life cycle energy analysis of a zero-energy house. Building Research \& Information. 41(4). 435-449.

Lapinskiene, V. and Martinaitis, V. (2013). The Framework of an Optimization Model for Building Envelope. Procedia Engineering. 57(2013). 670-677.

METEOTEST. (2014). METEONORM, Climatological data and typical years world wide. Retrieved from http://www.meteotest.ch/en/footernavi/solar_energy/meteonorm/

Natural Resources Canada. (2007). Community energy planning guide. Retrieved from

http://www.nrcan.gc.ca/sites/www.nrcan.gc.ca/files/canmetenergy/files/pubs /CommunityEnergyPlanningGuide_en.pdf

Natural Resources Canada. (2012). Appendix A - List of heating-degree days and ENERGY STAR zones. Retrieved from http://oee.nrcan.gc.ca/residential/business/manufacturers/zones.cfm

Natural Resources Canada. (2014). Comprehensive Energy Use Database 1990 to 2011. Retrieved from http://oee.nrcan.gc.ca/corporate/statistics/neud/dpa/trends_res_ca.cfm Date modified: January 29, 2014

Nunery, J. S., and Keeton, W. S. (2010). Forest carbon storage in the northeastern United States: Net effects of harvesting frequency, post-harvest retention, and wood products. Forest Ecology and Management 259 (2010) 1363-1375.

Passer, A., Kreiner, H., \& Maydl, P. (2012). Assessment of the environmental performance of buildings: A critical evaluation of the influence of technical 
building equipment on residential buildings. The International Journal of Life Cycle Assessment, 17(9), 1116-1130.

Passive House Institute. (2012). About Passive House - What is a Passive House?

Retrieved from

http://passiv.de/en/02_informations/01_whatisapassivehouse/01_

whatisapassivehouse.htm

PHIUS. (2012). PHIUS Tech Corner 6: Spray Polyurethane Foam Insulation and Passive Houses. Retrieved from

http://www.phius.org/documents/TechCorner/PHIUS_6_June_2012-06-21-

03_Spray_Polyurethane_Foam_Insulation.pdf

PHIUS. (2013a). PHIUS CPHC ${ }^{\circledR}$ Passive House Consultant Training 2013 [PowerPoint slides].

PHIUS. (2013b). The next generation passive energy modeling tool. Retrieved from http://www.phius.org/wufi-passive-other-tools/wufi-passive-and-othermodeling-tools/wufi-passive

PHIUS. (2013c). PHIUS Tech Corner 9. Retrieved from PHIUS website: http://phius.org/Tools-Resources/ProtocolsCalculators/Tech_Corner_9\%20Heat_Pump.zip

PHIUS. (2014a). PHIUS Certified Projects, Dublin PH. Retrieved from PHIUS website: http://www.phius.org/projects/1035

PHIUS. (2014b). PHIUS Certified Window Data for Designers \& Builders. Retrieved from http://www.phius.org/documents/PHIUS-Cert-Window-Data.html

PHIUS. (2014c). PHIUS+ Certification Guide. Revised April 28, 2014. 
PHIUS. (2014d). Climate Data (Data file). Retrieved from PHIUS website: http://www.phius.org/wufi-passive-other-tools/wufi-passive-and-othermodeling-tools/climate-data

Safa, A. A. (2012). Performance analysis of a two-stage variable capacity air source heat pump and a horizontal loop coupled ground source heat pump system. Theses and dissertations. Paper 756.

Sartori, I. and Hestnes, A.G. (2007). Energy use in the life cycle of conventional and low-energy buildings: a review article. Energy \& Buildings 39(3) 249-257.

Sathre, R. \& O'Connor, J. (2010). A Synthesis of Research on Wood Products \& Greenhouse Gas Impacts: $2^{\text {nd }}$ Edition. Vancouver, B.C. FPInnovations. (Technical report TR-19R). Retrieved from https://www.canfor.com/docs/whywood/tr19-complete-pub-web.pdf

Schnieders, J., Feist, W., Schulz, T., Krick, B., Rongen, L, \& Wirtz, R. (2011). Passive Houses for different climate zones. Wolfgang Feist, Passivhaus Institut and University of Innsbruck.

Statistics Canada. (2011). 2011 Census of Population, Statistics Canada Catalogue no. 98-313-XCB2011022. http://www12.statcan.gc.ca/census-recensement/indexeng.cfm

Statistics Canada. (2014a). Table 1-7 Primary and secondary energy, natural units Quebec. Report on Energy Supply and Demand in Canada. Retrieved from http://www.statcan.gc.ca/pub/57-003-x/2014002/t021-eng.htm

Statistics Canada. (2014b). Table 1-8 Primary and secondary energy, natural units Ontario. Report on Energy Supply and Demand in Canada. Retrieved from http://www.statcan.gc.ca/pub/57-003-x/2014002/t022-eng.htm 
Statistics Canada. (2014c). Table 1-11 Primary and secondary energy, natural units Alberta. Report on Energy Supply and Demand in Canada. Retrieved from http://www.statcan.gc.ca/pub/57-003-x/2014002/t025-eng.htm

Statistics Canada. (2014d). Table 1-11 Primary and secondary energy, natural units British Columbia. Report on Energy Supply and Demand in Canada. Retrieved from http://www.statcan.gc.ca/pub/57-003-x/2014002/t026-eng.htm

Stephan, A., Crawford, R. H., and de Myttenaere, K. (2013). A comprehensive assessment of the life cycle energy demand of passive houses. Applied Energy. 112 (2013) 23-34.

Tarion. (1990). Builder Bulletin 22: Floor Area Calculations. Retrieved from http://www.tarion.com/New-Home-Builders/Policies-andGuidelines/Builder\%20Bulletins/Bulletin22.pdf

U.S. Environmental Protection Agency. (2003). Climate Leaders Greenhouse Gas Inventory Protocol Core Module Guidance: Direct Emissions from Iron \& Steel Production. Retrieved from http://www.epa.gov/climateleadership/documents/resources/ironsteel.pdf

Wemhöner, C., and Afjei, Th. (2003). Seasonal performance calculation for residential heat pumps with combined space heating and hot water production (FHBB Method). Retrieved from http://www.bfe.admin.ch/dokumentation/energieforschung/index.html?lang= en\&publication=7926

Weyerhaeuser. (2014). Specifier's Guide for TJI s31, s33 and s47 Joists - East Canada. Retrieved from http://www.woodbywy.com/document/tj-4510/

Wünsch, B. (2014, March 3). Press Release: New Passive House categories also rate building energy gains. Passive House Institute. Retrieved from http://www.passivehouse- 
international.org/download.php?cms=1\&file=2014_03_03_New_Passive_House_ Categories_Press_Release.pdf

Wright, G. S., Klingenberg, K., and Pettit, B. (2014). Climate-Specific Passive Building Standards. Building America Report - 1405. Building Science Press. Retrieved from http://www.buildingscience.com/documents/bareports/ba-1405-draftclimate-specific-passive-building-standards/view

UltimateAir. (2014). UltimateAir, Energy Recovery Ventilation and Passive House. Retrieved from http://www.ultimateair.com/Portals/92089/docs/ultimateair\%20\&\%20passiv e\%20house\%20web.pdf

Zeller, Jr., T. (2010, September 25). Beyond Fossil Fuels: Can We Build a Brighter Shade of Green? New York Times. Retrieved from http://www.nytimes.com/2010/09/26/business/energyenvironment/26smart.html?_r=2\&ref=earth\&pagewanted=all 